


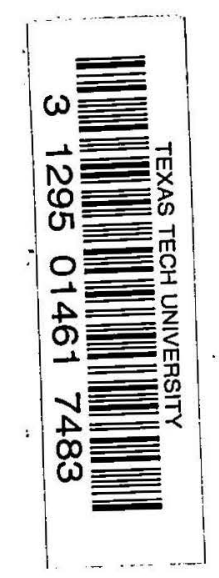






DEPARTMENT OF THE INTERIOR

UNITED STATES GEOLOGICAL SURVEY

CHARLES D. WALCOTT, DIRECTOR

\section{PRELIMINARY REPORT}

ON THE

\section{GEOLOGY AAD WATER RESOURCES OF NEBRASKA WEST OF THE ONE HUNDRED AND THIRD MERIDIAN \\ BY}

NELSON HORATIO DARTON

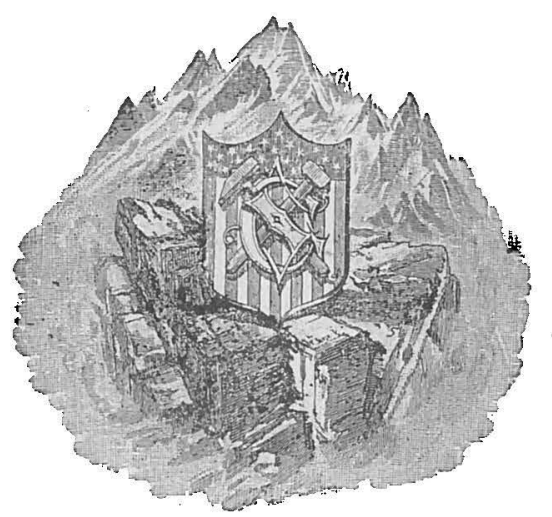

WASHINGTON

GOVERNMENT PRINTING OFFICE 1903 



\section{ONTENTS.}

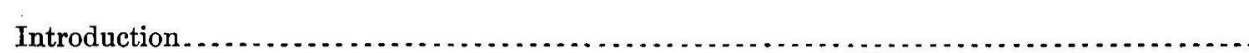

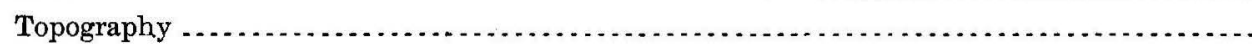

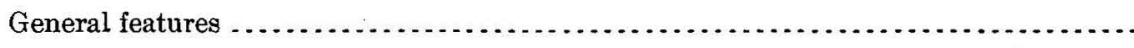

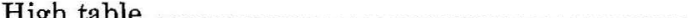

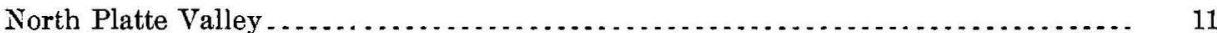

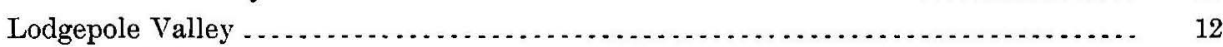

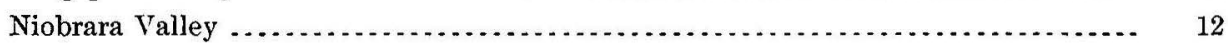

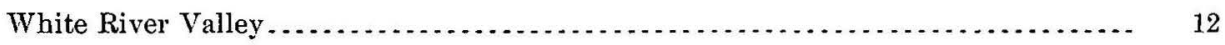

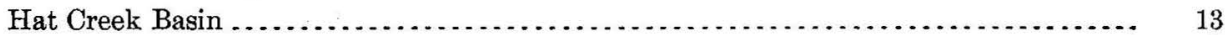

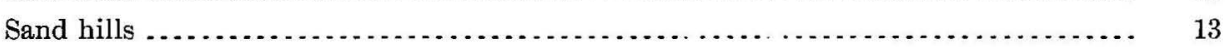

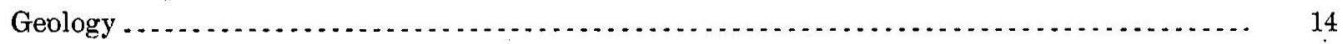

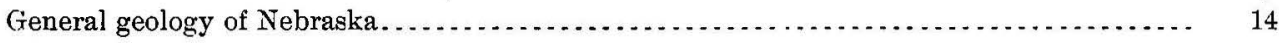

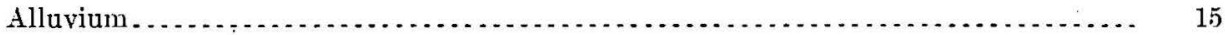

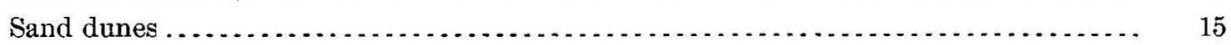

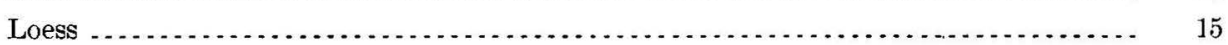

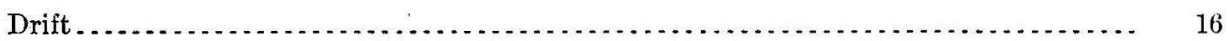

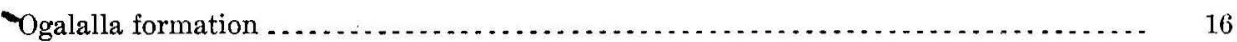

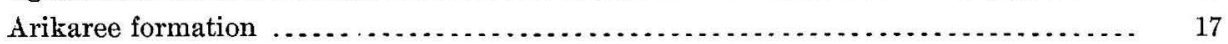

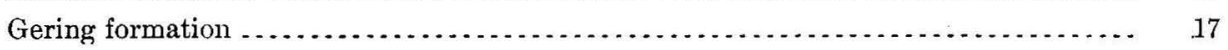

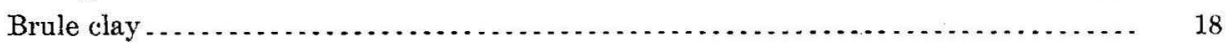

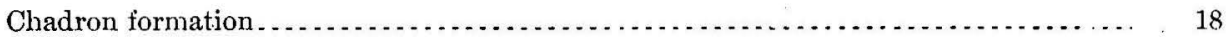

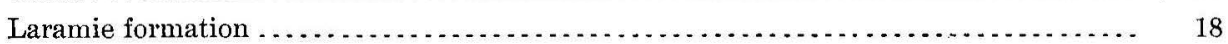

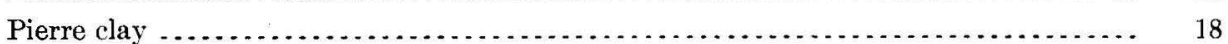

Niobrara and Benton formations . . . . . . . . . . . . . . . . . . .

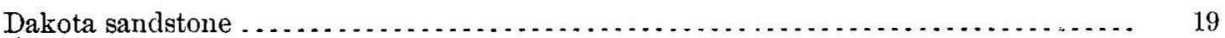

Carboniferous formations.................................................... 20

Geology of the region west of the one hundred and third meridian $\ldots \ldots \ldots \ldots \ldots \ldots \ldots . \ldots 21$

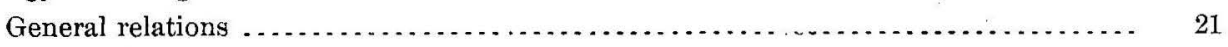

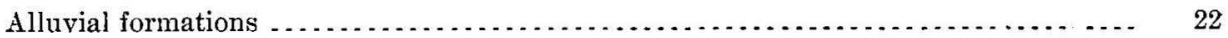

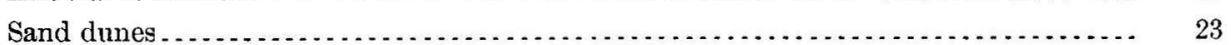

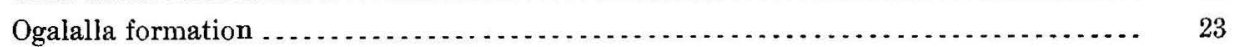

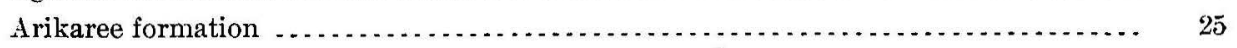

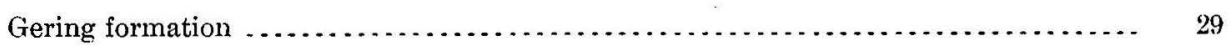

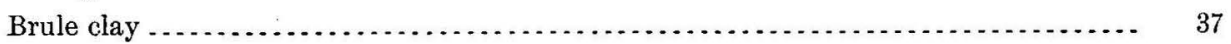

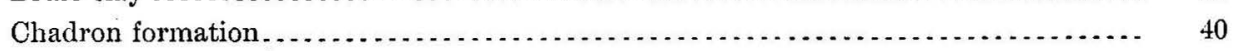

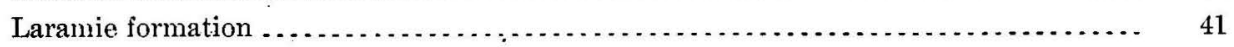


Geology-Continued.

Geology of the region west of the one hundred and third meridian-Continued.

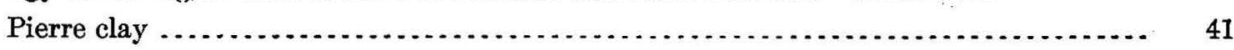

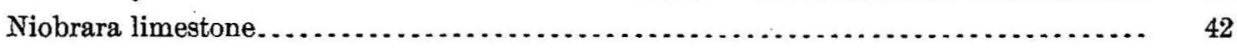

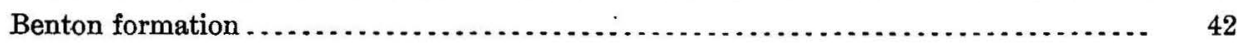

Dakota sandstone ...................................................... ${ }_{42}$

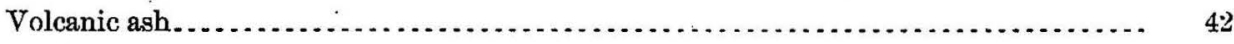

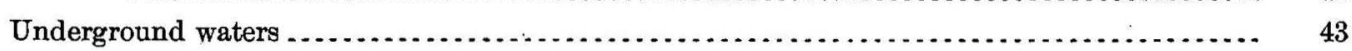

General conditions...................................................... 43

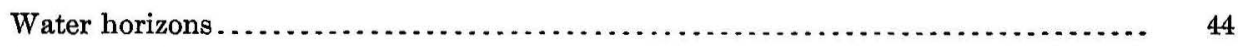

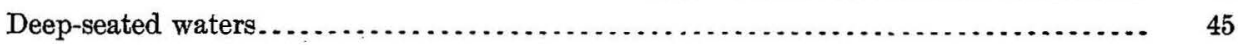

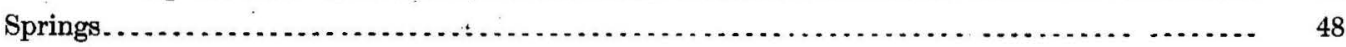

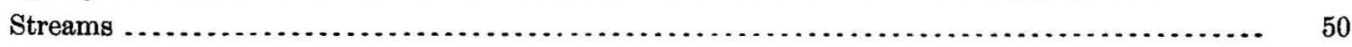

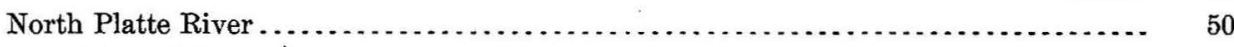

Pumpkinseed Creek..................................................... 51

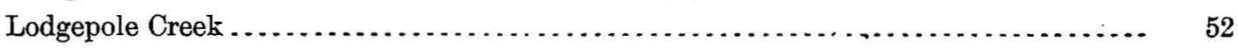

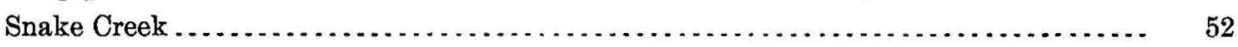

Niobrara River.

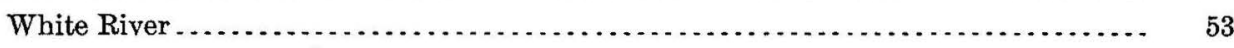

Hat Creek Basin ...................................................... 54

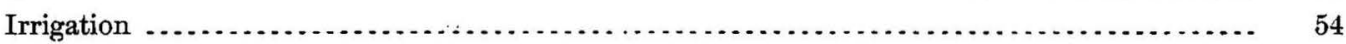

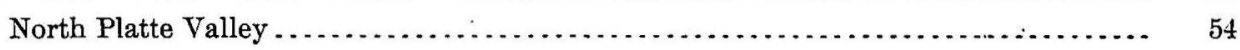

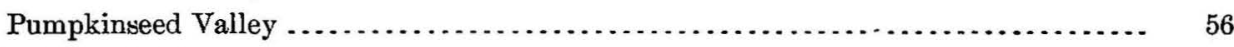

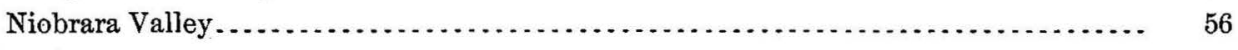

White River Basin .................................................. 57

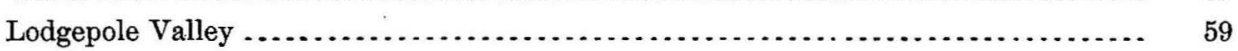

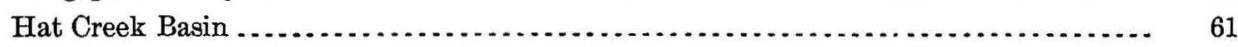

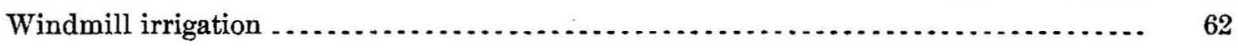

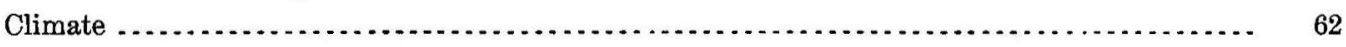

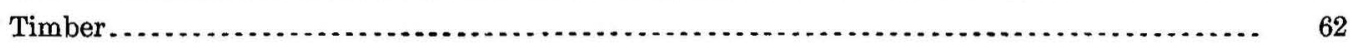

List of elevations in Nebraska west of the one hundred and third meridian ............... 63

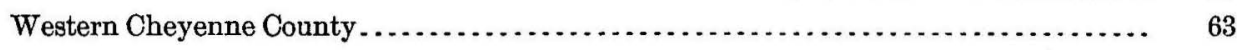

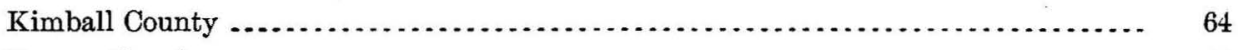

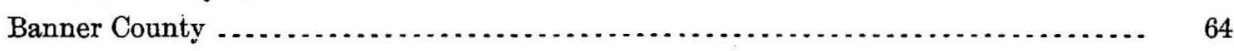

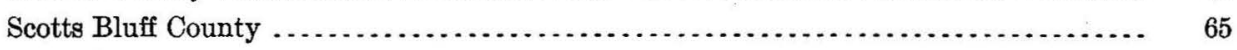

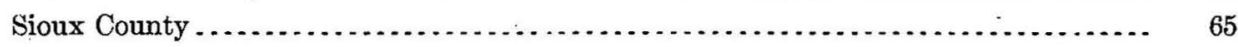

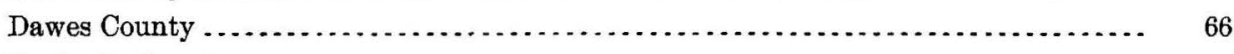

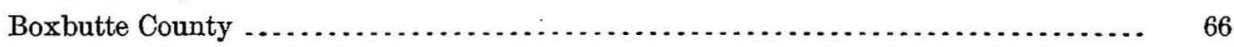

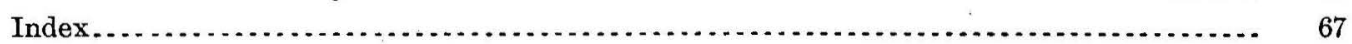




\section{ILLUSTRATIONS.}

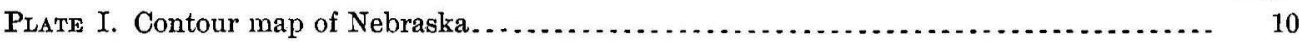

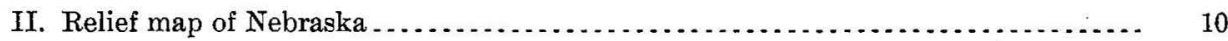

III. Scotts Bluff, from north side of North Platte River . . . . . . . . . . . . . . . . . . . . 12

IV. Courthouse and Jail rocks, from the south $\ldots \ldots \ldots \ldots \ldots \ldots \ldots \ldots \ldots \ldots \ldots \ldots \ldots \ldots \ldots$

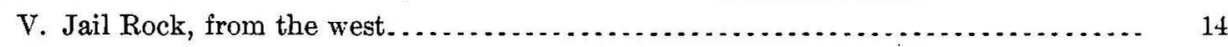

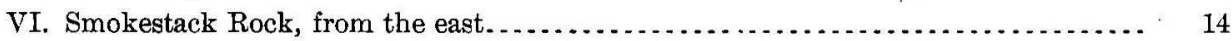

VII. A, Twin Sisters, Banner County, Nebr.; $B$, Wind erosion in Gering formation,

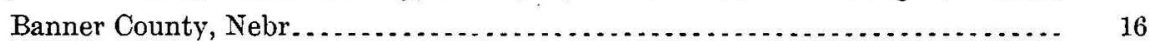

VIII. North face of Pine Ridge, looking northeast over Hat Creek Basin. . . . . . . . . . . 16

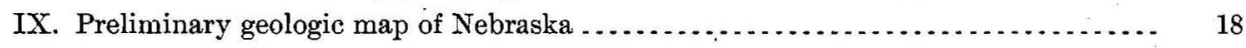

X. Cross section from the Rocky Mountains to Omaha, across Nebraska. ........... 18

XI. Geologic map of Nebraska west of the one hundred and third meridian .......... 20

XII. Cross sections of Nebraska west of the one hundred and third meridian ......... 20

XIII. Typical sand bills in western Cheyenne County, Nebr . . . . . . . . . . . . . . . . . . 22

XIV. A, Conglomerate at base of Ogalalla formation, 5 miles south-southeast of Redington, Cheyenne County, Nebr.; $B$, Conglomerate in Arikaree formation, 3 miles due

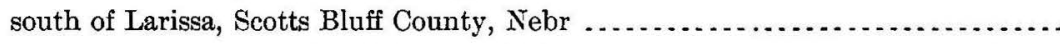

XV. Sections of exposures of Arikaree and Ogalalla formations, at and near Langs Point, Nebr.

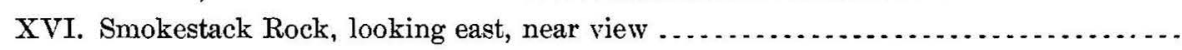

XVII. A, Butte of Arikaree formation, Sowbelly Canyon, Sioux County, Nebr.; $B$, Arikaree formation on Brule clay, southwest portion of Sioux County, Nebr.....

XVIII. A, Blowout with core, Arikaree formation, Sioux County, Nebr.; B, Pipy. concretions, Arikaree formation, Scotts Bluff County, Nebr..................... 28

XIX. Dæmonelix beds in Arikaree formation, northern Sioux County, Nebr . .......... 28

XX. Gering formation with fault, near Rutland, Dawes County, Nebr .............. 30

XXI. Cliffs of Arikaree formation, north face of Pine Ridge, Sioux County, Nebr...... $\quad 30$

XXII. Arikaree formation, Gering formation, and Brule clay in Birdcage Gap, Cheyenne County, Nebr .

XXIII. Cross sections showing relations of formations near Chimney Rock and Horseshoe Flat, Nebr.

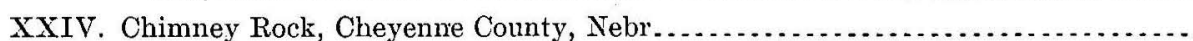

XXV. Gering formation lying unconformably on Brule clay, Cheyenne County, Nebr....

XXVI. Sections of exposures, showing the relations of (iering and associated formations, Cheyenne County, Nebr

XXVII. Sections of exposures, showing the relations of Gering and associated formations from Chimney Rock to Castle Rock 
Plate XXVIII. Sections of exposures, showing the relations of Gering and associated formations south and southwest of Larissa, Nebr ......................... 38

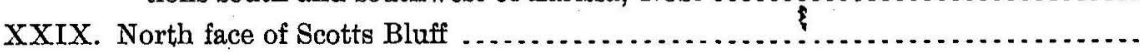

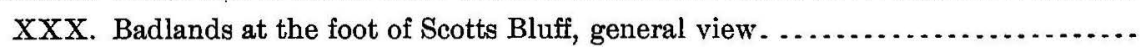

XXXI. Badlands at the foot of Scotts Bluff, near view . ..........................

XXXII. $A$, Castle Rock, Scotts Bluff County, Nebr., from the east; $B$, Lens of coarse material in Brule formation, 4 miles south of Gering, Nebr...............

XXXIII. Badlands of Brule formation west of Adelia, Sioux County, Nebr ............

XXXIV. "Toadstool Park" in badlands, northwest of Adelia, Sioux County, Nebr.....

XXXV. Titanotherium robustum

XXXVI. Typical fossils of Niobrara chalk and Greenhorn limestone ................

XXXVII. Map showing distribution of underground waters in Nebraska west of the one hundred and third meridian.

XXXVIII. Contour map of the Upper Missouri region, showing factors bearing on pros-

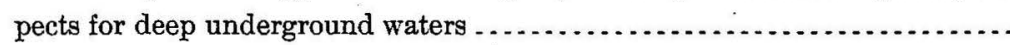

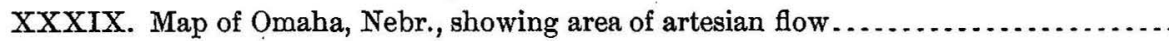

XL. Irrigation map of the North Platte Valley in Nebraska west of the one hundred and third meridian

XLI. Irrigation map of the Niobrara River, White River, and Hat Creek regions in Nebraska, west of the one hundred and third meridian ..................

XLII. Diagram of rainfall at localities in western Nebraska, 1884 to $1897 . \ldots . . . . . . .$.

XLIII. Map showing distribution of timber in western Nebraska ..................

Fig. 1. Columnar section of formations exposed in Wildcat Mountain and vicinity ............

2. Section 6 miles southwest of Gering, Nebr., showing relations of Arikaree and Brule formations .

3. Section of Arikaree and Brule formations on the north side of the valley of North Platte River

4. Section 4 miles northwest of Dorrington, Nebr., showing position of conglomerate in Arikaree formation

5. Section 8 miles south-southeast of Gering, Nebr., showing relations of conglomerate in Arikaree formation

6. Cross section from eastern end of Spoon Butte to Sturdivant ranch, looking east. ......

7. Section of bluff in southwest corner of Sioux County, showing relations of supposed Gering formation

8. Details of unconformity beftween Brule clay and supposed Gering deposits in the valley of Lawrence Fork

9. Cross section of ridge 10 miles south of Gering, Nebr., looking west........................

10. Section 8 miles due south of Gering, Nebr .

11. Section of Gering and associated formations 6 miles south-southwest of Gering, Nebr ...

12. Section of Gering and associated formations 7 miles south-southwest of Gering, Nebr ...

13. Section of Gering and associated formations in Cedar Canyon, 8 miles southwest of Gering, Nebr...

14. Section of Gering and associated formations at the mouth of Cedar Canyon, 7 miles southwest of Gering, Nebr

38
38

40

40

42

42

44

44

46

46.

48

50

54

56

62

64

24

25

26

27

28

28

30

31

32

32

33

34

34 
Section at Signal Butte, Scotts Bluff County, Nebr.

16. Section of Gering and associated formations 2 miles northeast of Dorrington, Nebr.... 36

17. Section in vicinity of Funnel Rock, 1 mile north of Ashford, Nebr................ 37

18. Section of north face of Scotts Bluff ...........................................

19. Section from Round Top to Adelia station, Sioux County, Nebr . . . .

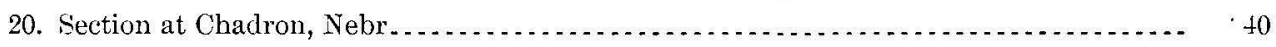

21. Section from the Black Hills to Pine Ridge, in western Nebraska................ 46

22. Diagram of apparatus illustrating the declivity of head of liquids flowing from a reserroir. $\quad 47$

23. Section to illustrate some characteristic features of springs in western Nebraska ....... 49 



\title{
PRELIMINARY REPORT ON THE GEOLOGY AND WATER RESOURCES OF NEBRASKA WEST OF THE ONE HUNDRED AND THIRD MERIDIAN. ${ }^{a}$
}

\author{
By Nelson Horatio Darton.
}

\section{INTRODUCTION.}

This report is based on field work of the season of 1897. It is designed mainly to furnish information in relation to the geologic structure and the prospects for underground waters. A general account will also be given of the surface waters and their present and prospective use for irrigation, etc. The region is the portion of Nebraska lying west of the one hundred and third meridian, comprising Sioux, Scotts Bluff, Banner, and Kimball counties, the western portions of Cheyenne and Boxbutte counties, and the central and western portion of Dawes County; in all, an area of 7,400 square miles, adjoined on the west by $W$ yoming, on the north by South Dakota, and on the south by Colorado. It lies on the Great Plains south of the Black Hills of South Dakota. The Scotts Bluff, Banner, and Cheyenne counties areas were examined in detail, but time did not permit more than a general reconnaissance of the adjoining regions. I was assisted by Mr. C. A. Fisher, who obtained the data for the greater part of Kimball and Boxbutte counties. For several months I was accompanied by Prof. E. H. Barbour, the acting State geolo gist of Nebraska, who did much to further the progress of the work.

Numerous data in regard to irrigation in the Niobrara River, White River, and Hat Creek basins were kindly furnished by Mr. J. M. Wilson, the State engineer.

\section{TOPOGRAPHY.}

General features.-The region is a typical portion of the Great Plains, which extend far eastward from the foot of the Rocky Mountains. To the south this portion of the plains is traversed by the deep, broad valley of North Platte River and the smaller valleys of Niobrara River and Lodgepole Creek; to the north, at the

$u$ This is a reprint of the paper in the Nineteenth Annual Report of the United States Geological Survey, 1897-98, Part IV, pp. 719-785, Plates LXXIV-CXVIII, published in 1899. In the present edition there are only a few corrections in some of the maps and a few minor changes in statements regarding geology. An index has been added and there is new pagination and renumbering of plates and figures. 
valleys of. White River and Hat Creek, it gives place to lowlands extending to Cheyenne River at the southern foot of the Black Hills. The northern edge of the plains presented toward these lowlands is marked by a great escarpment, or line of steep slopes, which is known as Pine Ridge. It begins in Wyoming and is the most conspicuous topographic feature in northwestern Nebraska.

Pl. XI has for its base a topographic map of the region, with contour lines 100 feet apart. These contour lines indicate heights above the sea, and they are numbered accordingly. The lines for every even 500 feet are made heavier than the others. Contour lines are lines of equal elevation, consequently they are drawn along the slopes of valleys like level irrigation ditches, in this case 100 feet apart vertically, extending up the side valleys, and running out around the points of projections. They encircle detached hills, and an isolated hill rising 500 feet above the plain would be indicated by five of the 100 -foot contour lines. From the foregoing statement, it will be seen that contour lines are crowded near together on steep slopes, but are widely separated on the plains and in the river bottoms. Thus, they indicate the shape of the land as well as its elevation.

For Banner, Scotts Bluff, and portions of Cheyenne and Sioux counties, the contour map is based on the detailed maps, with 20-foot contour lines, of the Scotts Bluff, ${ }^{a}$ Camp Clarke, ${ }^{a}$ and Whistle Creek quadrangles of the United States Geological Survey. In other portions of the region it has been necessary to employ barometer readings and local observations extending from points of known heights on the several railroad lines. These approximate data are distinguished on the map hy broken contour lines.

Pl. II is a view of a relief map of Nebraska, which also shows the configuration of this area.

High table.-The original surface of the region to which this report relates was a relatively smooth plain, which sloped gently to the east. This plain was uplifted in early Pleistocene time, and the rivers extending across it excavated valleys of greater or less width and depth, soon giving rise to the broader features of the present configuration. The remains of the plain lie between the valleys, where they constitute wide areas of high table-lands, smooth or very gently rolling in contour, and sloping to the east. The widest areas of this table lie on each side of the valley of Lodgepole Creek, and extend north from the valley of North Platte River to the great escarpment of Pine Ridge, where there is an abrupt descent of over 1,000 feet to a region of low rolling plains which extend to Cheyenne River at the southern foot of the Black Hills. Some features of this great escarpment are shown in Pls. II, VIII, XVII, and XXI. The broad area of table terminating in Pine Ridge is

a Topographic maps of these two quadrangles have recently been issued by the Survey and may be obtained by remitting 10 cents ( 5 cents for each) to the Director, United States Geological Survey, Washington, D. C. 



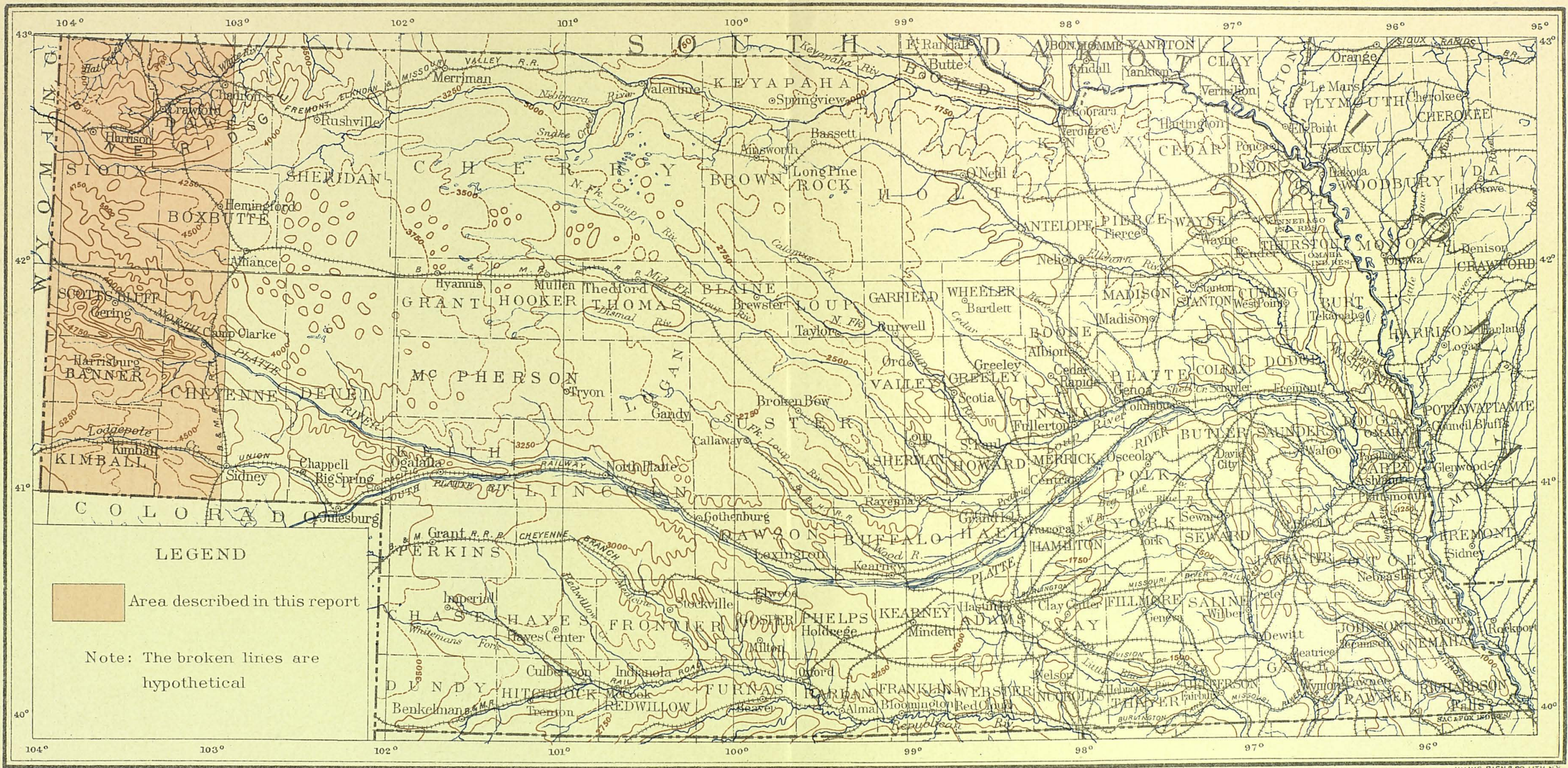

CONTOUR MAP OF NEBRASKA, COMPILED FROM U.S.GEOLOGICAL SURVEY MAPS AND RAILROAD DATA BY N.H. DARTON 1898

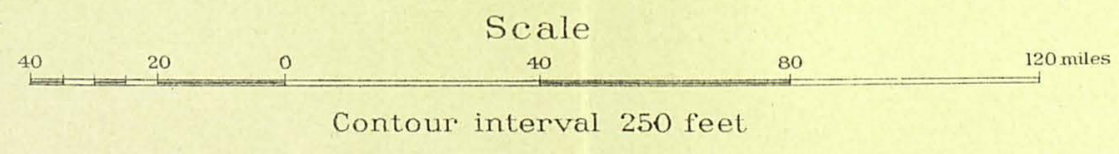






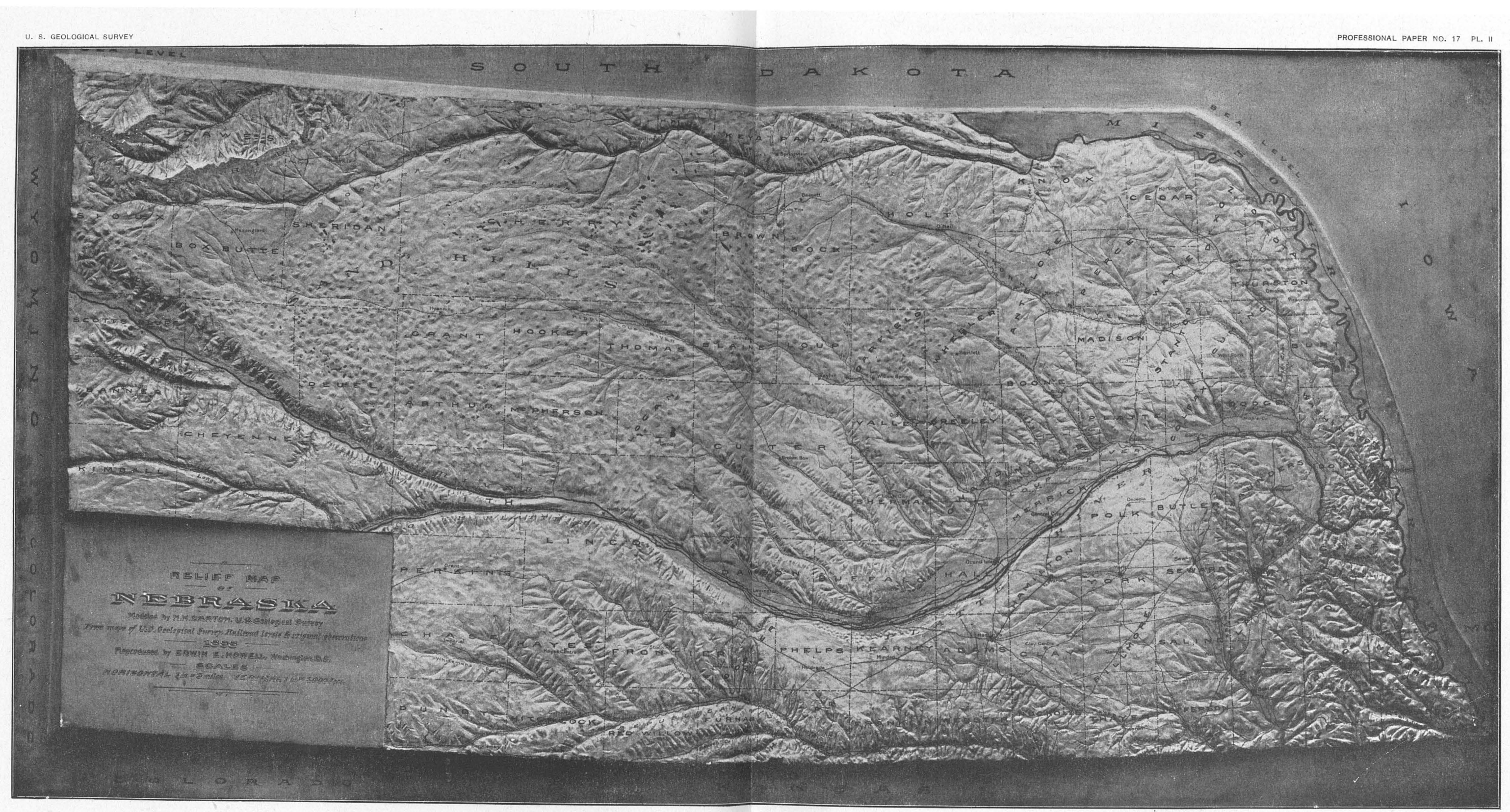

RELIEF MAP OF NEBRASKA, 

traversed by the wide, shallow valley of the Niobrara, south of which it is surmounted by irregular zones of sand hills. The edge of the table descending to the valley of North Platte River presents steep slopes deeply notched by canyons. Next south, there is an outlying area of the high plain, preserved as a long, high, narrow ridge lying between the valleys of Pumpkinseed Creek and North Platte River. This ridge is so narrow and so deeply invaded by canyons that it has lost the flat-topped character, except in a few small areas in its widest portions. Its summits, however, in many cases rise to the plateau level. The ridge owes its isolation to a former channel of Horse Creek, which at one time flowed through the Pumpkinseed Valley. Eight miles south, across the valley of Pumpkinseed Creek, a branch of North Platte River, rises the steep face of the wide area of high table-land extending to the valley of Lodgepole Creek, and continuing beyond that valley far into Colorado. The altitudes on the table-land average about 4,300 feet along the one hundred and third meridian, and increase to nearly 5,000 feet in the vicinity of the Wyoming line. In the southwestern portion of Banner County, and again in the extreme southwestern portion of the State, the altitudes somewhat exceed 5,300 feet. Here is found the highest land in the State. Scotts Bluff has the reputation of being the highest point, but its altitude is only 4,662 feet. Wildeat Mountain, which has shared the claim as the highest point, is 5,038 feet, or fully 300 feet lower than the highest points on the high table along the $W_{y}$ oming line.

North Platte Valley. - The region is traversed near its center by the broad valley of North Platte River, a stream which enters the State from Wyoming and carries the drainage of a wide area in the Rocky Mountains. This valley has been excavated from the plain which, as before stated, originally extended unbroken entirely across the western Nebraska region. The depth of the valley averages in the greater part about 700 feet, and its width varies from 10 to 15 miles. The slopes along its sides present many irregularities. There is first a broad flat along the river, which rises only a few feet above the water. This flat merges into irregular terraces, rising for about 200 feet, with slopes of varying degrees of steepness. Then come steep-sided projections of high lands extending from the edge of the high table above and separated by canyons which are cut into the margin of the table for some distance. These canyons have been excavated by small streams which flow into Platte River in times of heavier rainfall. The higher slopes of the valley are marked by cliffs and buttes of varied form and height, which often are very imposing in appearance. On the south side of the valley there rises an irregular ridge of striking prominence, cut off from the main high table to the south by the wide valley of Pumpkinseed Creek. The greater part of this ridge varies in width from 3 to 6 miles, with long projecting spurs and occasional outlying buttes. Its crest is relatively uniform in height, about 800 feet above the bottom of the Platte Valley. In the vicinity of 
the Wyoming line its altitude diminishes greatly, but it is practically isolated from the high tables southward. The main axis of the ridge is about 7 miles south of the river, but several spurs extend nearly to the river. One of these terminates in Chimney Rock, shown in Pl. XXIV; another at Castle Rock, shown in Pl. XXXII; and a third at Scotts Bluff; shown in Pl. III. To the east this ridge terminates in two outlying buttes, known as Courthouse and Jail rocks, shown in Pls. IV and V. It also sends a branch ridge out into the Pumpkinseed Valley, on which there are some particularly high knobs, one of which is known as Wildcat Mountain and the other as Hogback Mountain, in which an altitude of somewhat over 5,000 feet is attained. The western part of the ridge has an altitude of 4,860 feet. Scotts Bluff has an altitude of 4,662 feet and Courthouse Rock 4,100 feet. The ridge is deeply invaded by numerous canyons, which have cut away nearly all its original tabular surface. Toward its eastern extremity its lower slopes bear extensive accumulations of sand hills, notably in the region south of Camp Clarke.

The Pumpkinseed Valley south of this ridge is elevated somewhat above the valley of North Platte River, into which it opens at Lapéer. It varies in width from 7 to 12 miles. It is characterized by gentle slopes, which extend north to the steep slopes and buttes of the ridge above described, and to the south to the cliffs and canyons at the edge of the high table. Lawrence Fork, the principal branch of Pumpkinseed Creek, occupies a valley which heads to the south and west on the surface of the table-lands.

Lodgepole Valley.-Lodgepole Creek has cut a narrow, steep-sided trough in the plains to a depth averaging 300 feet. The valley contains a flat which has a declivity of about 17 feet to the mile, having an altitude of about 4,100 feet on the one hundred and third meridian and nearly 5,000 feet at the Wyoming line. Its average width varies from $1 \frac{1}{2}$ to 3 miles. The principal branch is Sidney Draw, the two forks of which rise on the table-land in the vicinity of the Colorado line.

Niobrara Valley.-The Niobrara River flows in a wide, relatively shallow valley, high up on the table-lands lying between the valley of North Platte-River and the crest of Pine Ridge. It enters Nebraska from Wyoming, flows southeast for 20 miles, and then nearly due east. At the $W_{y}$ oming line its altitude is about 4,700 feet, and at the one hundred and third meridian about 3,900 feet, which indicates a gradient of 13 feet to the mile. The valley bottom is seldom over half a mile in width, with gentle slopes interrupted by occasional low cliffs. The bottom of the valley is only from 400 to 500 feet below the crest of Pine Ridge, and it is uniformly about 400 feet above the level of North Platte River along a north-northeast and south-southwest line, while to the north the lowlands beyond Pine Ridge are at altitudes about 600 feet lower than Niobrara River.

White River Valley.-White River rises in Pine Ridge, near Harrison, at an 


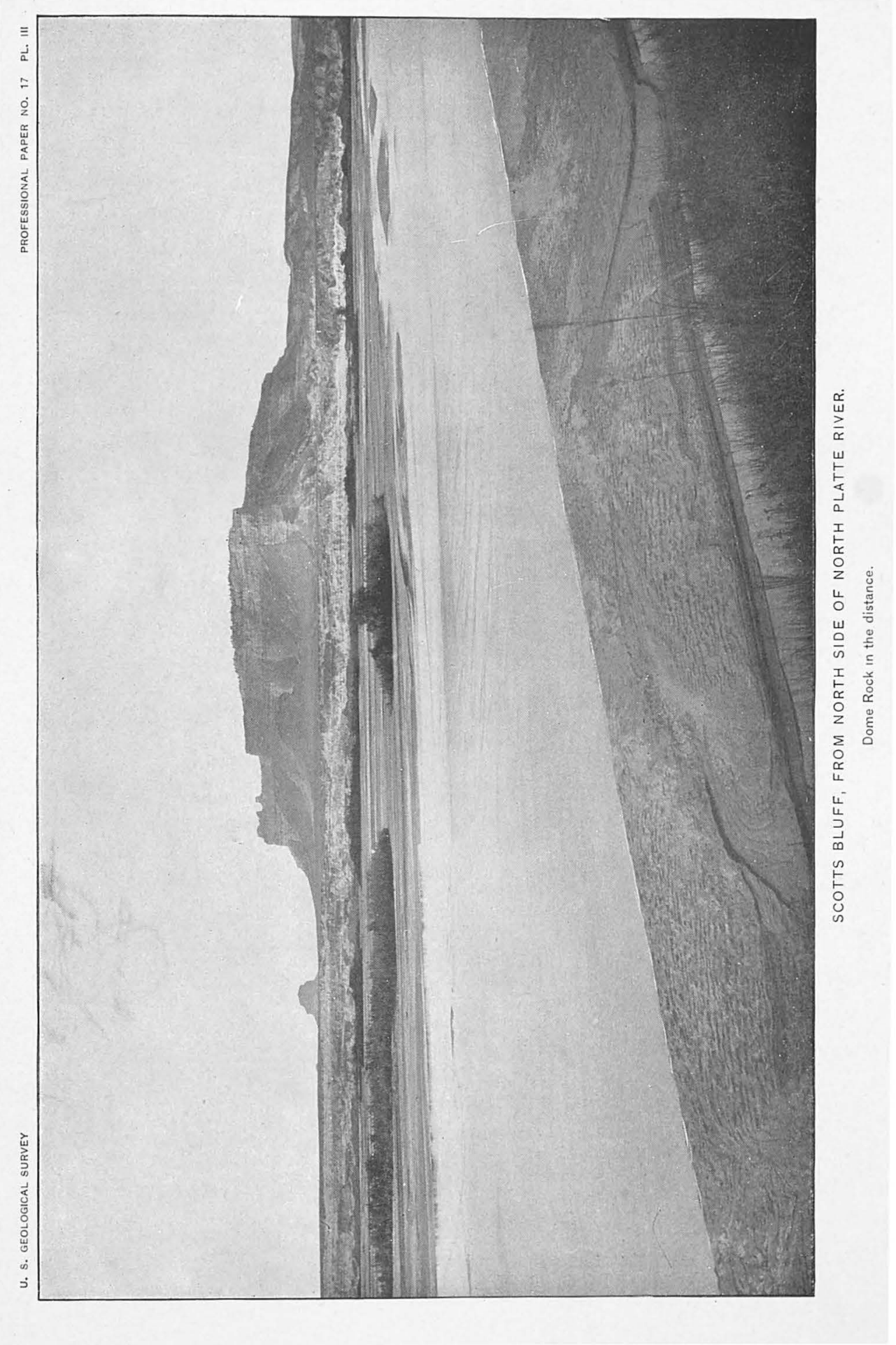





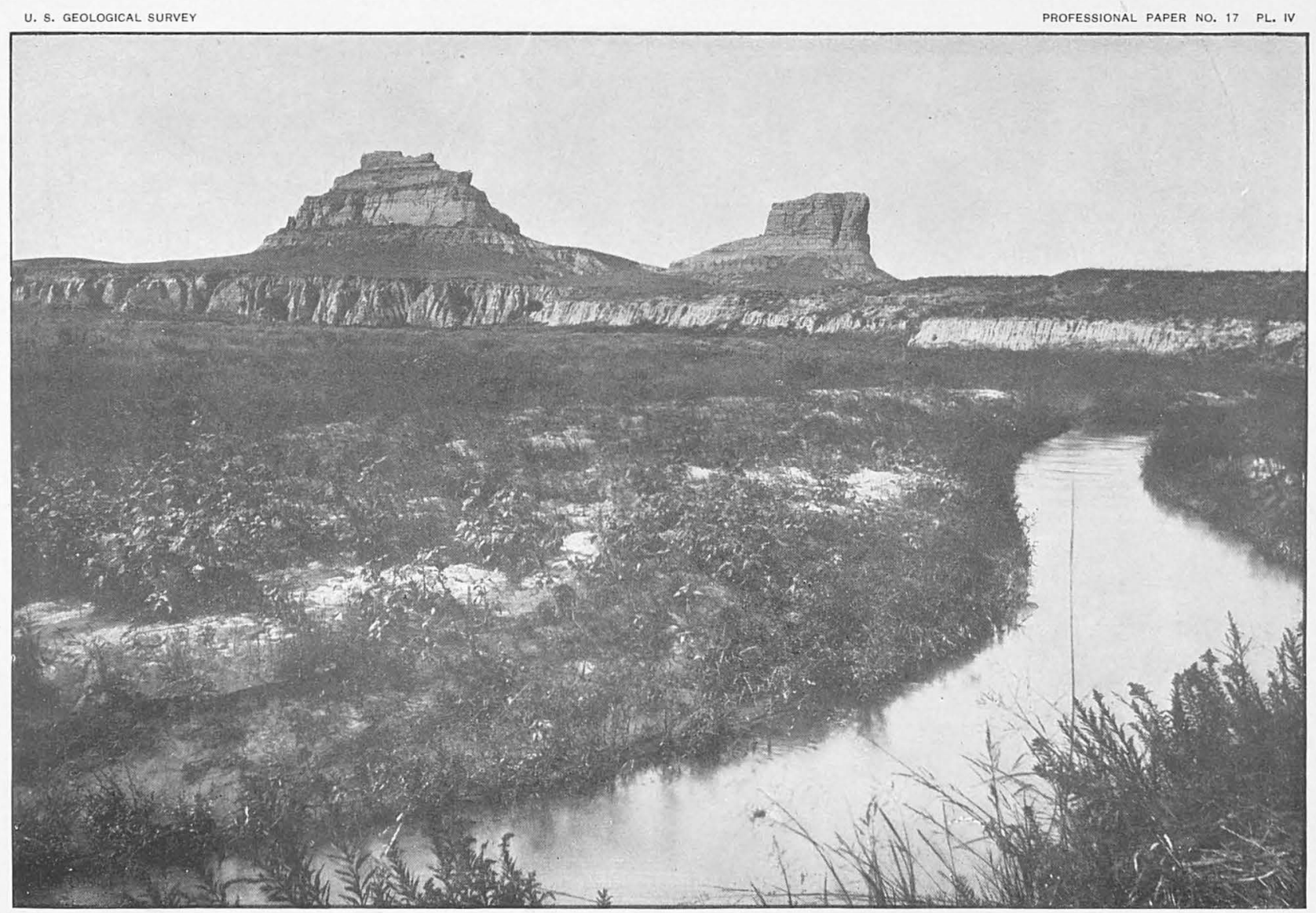

COURTHOUSE AND JAIL ROCKS, FROM THE SOUTH.

Courthouse Rock irrigation canal in the foreground. 

altitude of about 4,800 feet, or several hundred feet higher than Niobrara River, a short distance to the southwest. It flows to the east, and has excavated a gorge in the northern face of Pine Ridge, which has a fall of 1,100 feet in the first 20 miles, a declivity of 55 feet to the mile. Near Crawford the valley of White River merges into the rolling plains at the foot of Pine Ridge, and then extends northeast as a wide, shallow depression among rolling hills, in which its declivity is only 20 feet to the mile. Its altitude at the one hundred and third meridian is about 3,100 feet. The river receives many streams from the deep canyons in the northern front of Pine Ridge, and a number of intermittent creeks from the rolling country northward.

Hat Creek Basin.- Hat Creek is a branch of the South Fork of Cheyenne River. It rises in a canyon in the north front of Pine Ridge, in Sioux County, and receives numerous branches also heading in this front. To the east, where Pine Ridge trends southeast and passes around toward the head of White River, the divide between the Hat Creek and White River drainages is a low, narrow ridge, which projects from the spur of Pine Ridge near Adelia, and extends far to the northeast into South Dakota. The highest points on this divide beyond Round Top, the high spur of Pine Ridge, are some outlying mounds, of which the most conspicuous is the Sugar Loaf, due north of Adelia. Where the ridge is crossed by the Burlington and Missouri River Railroad, north-northwest of Adelia, the altitude is 3,816 feet. From the Sugar Loaf northeast the ridge is moderately high for some distance, and then gradually diminishes in height. It is crossed by the Deadwood line of the Fremont, Elkhorn and Missouri Valley Railway at an altitude of about 3,650 feet.

The upper portion of the Hat Creek Basin consists of deep canyons extending far into the north front of Pine Ridge. The sides of these canyons rapidly diminish in height to the north, and soon give place to a region of low rolling hills having a generally gentle slope northward. On the South Dakota line the altitude of Hat Creek is about 3,500 feet.

Sand hills.-There is in this portion of western Nebraska a narrow extension of the great 'sand-hill area of Nebraska. The hills are comprised in a serics of detached groups that lie mainly in the northern portion of Cheyenne and the southcentral portion of Sioux 'counties and cover an area of about 300 square miles. Their distribution is shown on the map, Pl. XI. The hills are mainly from 50 to 150 feet in height, and the areas consist of assemblages of irregular dunes with intervening basins and valleys. In T. 26, R. 55 , and T. 27, R. 56 , there are some exceptionally high sand hills, which rise somewhat over 5,000 feet in altitude, or from 200 to 250 feet above the surrounding plain. The lower dunes are in greater part covered with a scanty growth of grass, but there are many areas of considerable extent in which the sand is bare and loose. These localities are generally "blowouts" on the northwest slopes of the larger dunes. There is an extensive local sand-hill area along the south side of the valley of North Platte River, on the 
slopes south of Camp Clarke, which extends as far eastward as the vicinity of Courthouse Rock. The width of this belt is but 5 miles at most, and its length about 15 miles. An area of smaller size lies just west of Chimney Rock.

\section{GEOLOGY.}

GENERAL GEOLOGY OF NEBRASKA.

The geology of Nebraska presents broad structural features which it is necessary to outline before a clear idea can be given of the local relations in the western portion of the State. The principal formations which outcrop are extensive sheets of sands and clays of Cretaceous, Tertiary, and Pleistocene age, underlain by Carboniferous limestone, which outcrops in the southeastern counties. In the map, $\mathrm{Pl}$. IX, an attempt has been made to indicate the present state of knowledge of the distribution of the principal formations. It is based on a large number of new data from personal observations. In the cross section, $\mathrm{Pl}$. X, are shown the principal structural relations of the formations. The following list sets forth their order, age, and salient features:

Table of geologic formations in Nebraska.

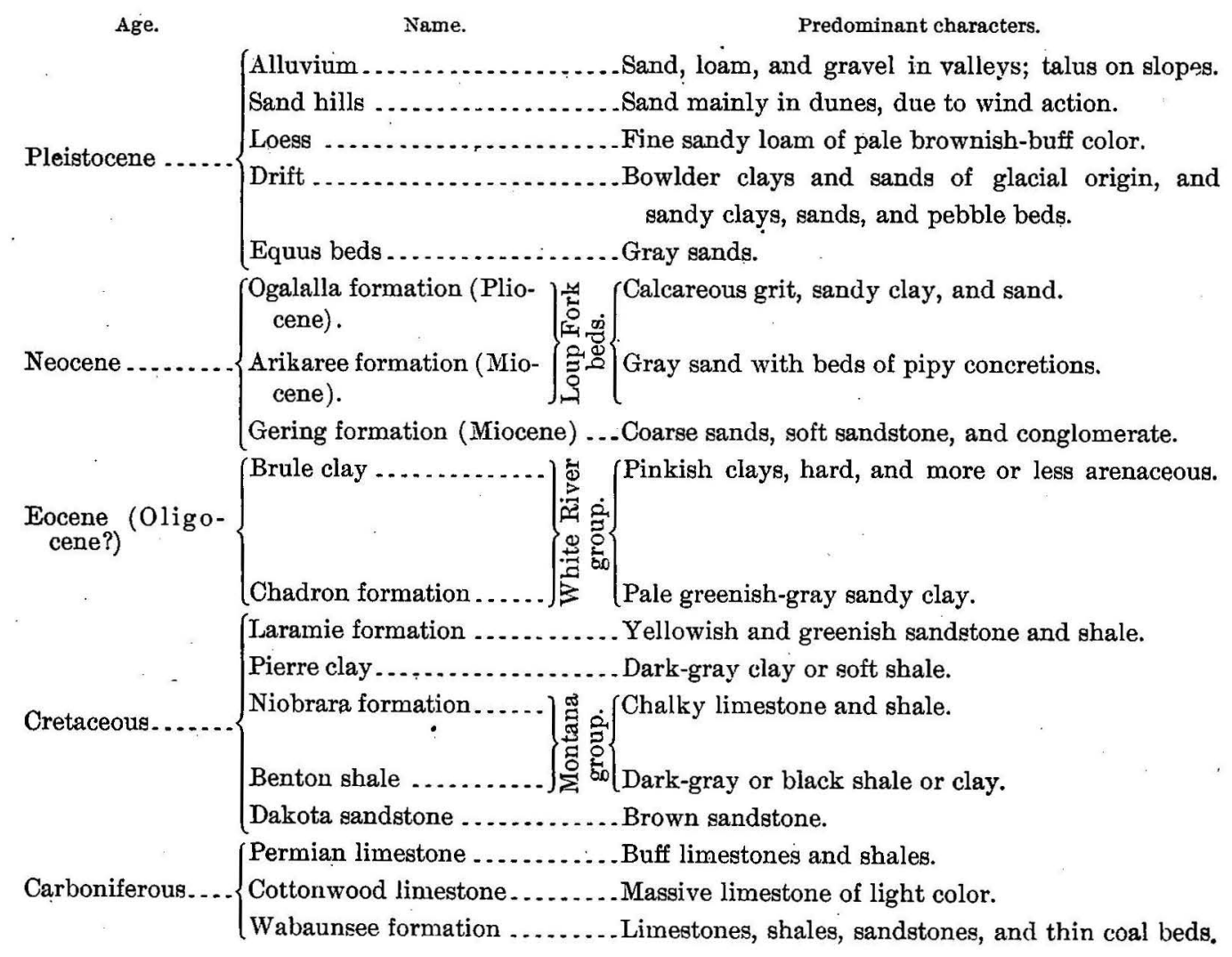




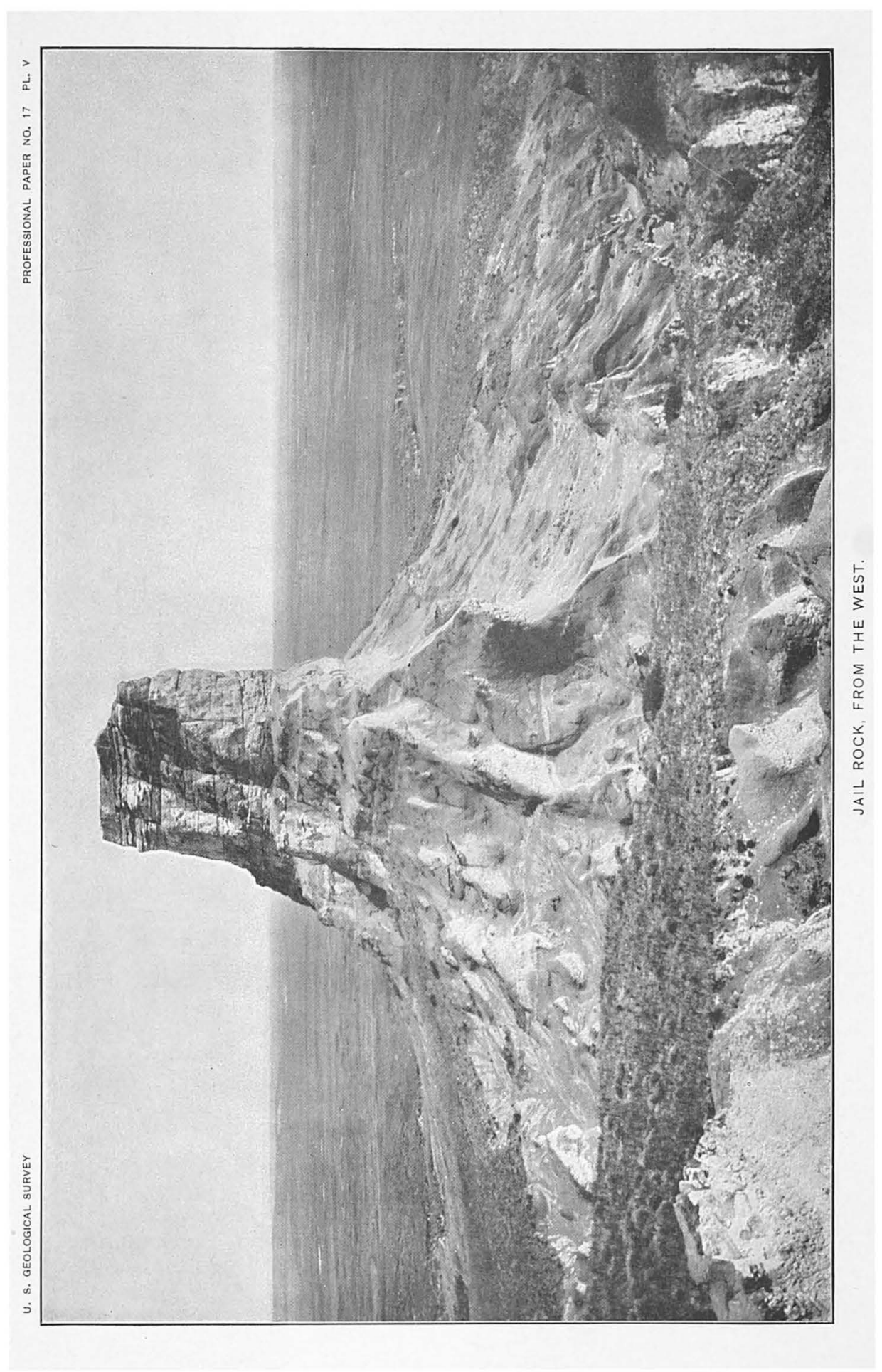



U. S. GEOLOGICAL SURVEY PROFESSIONAL PAPER NO. 17 PL. VI

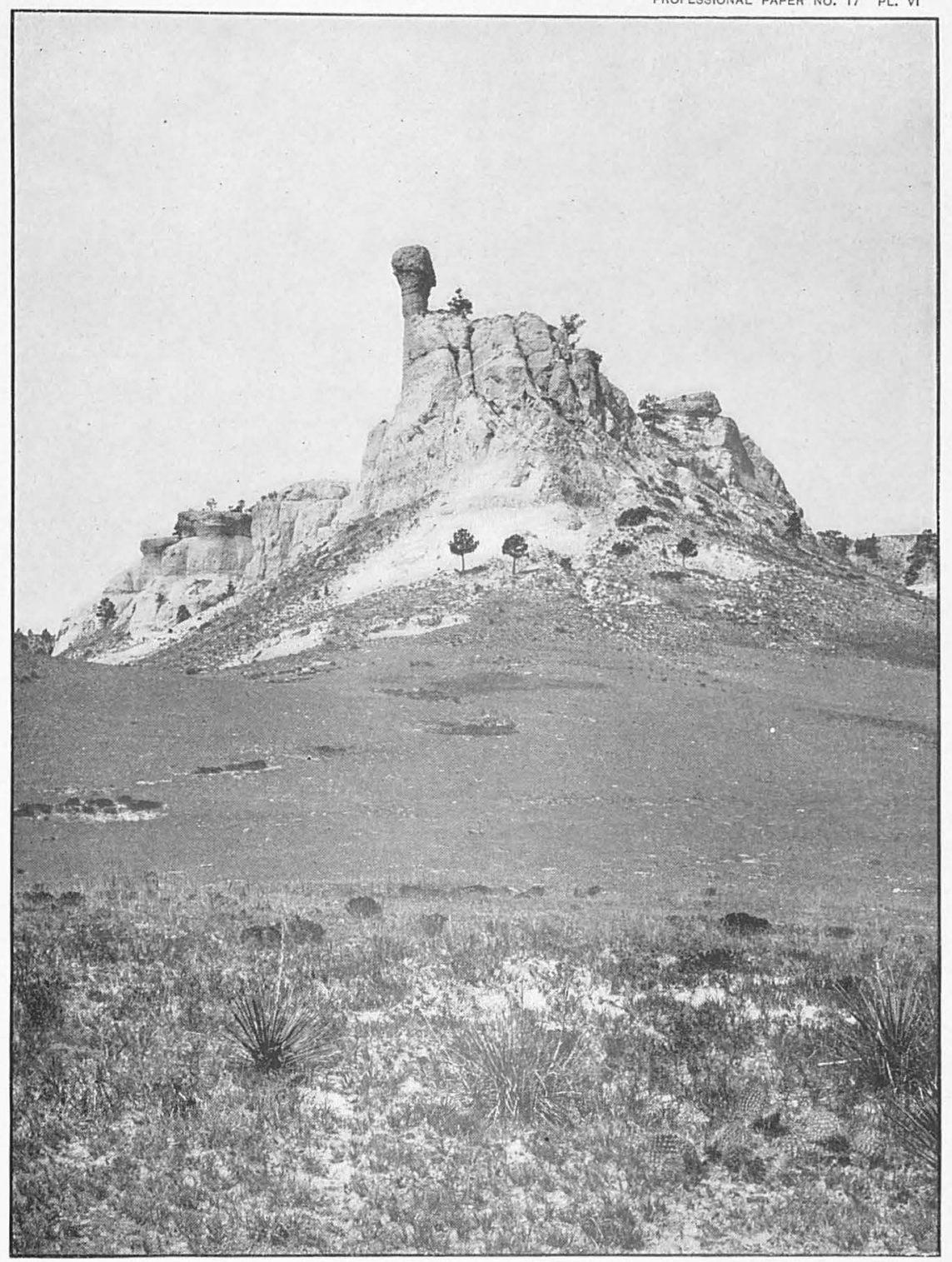

SMOKESTACK ROCK, FROM THE EAST.

Showing outliers of conglomerate in Arikaree formation. 

Alluvium.-Owing to the softness of the Cretaceous and Tertiary formations which constitute the surface of the greater part of Nebraska, the river valleys are wide, and they are floored to a greater or less depth with deposits of alluvial materials brought by the streams at various stages of their development. The largest alluvial areas are along the valley of Platte River, which has a width of 15 miles in the central portion of the State. Southwest of Omaha, where the river crosses the hard rocks of the Carboniferous which rise in the eastern part of the State, its valley is narrowed greatly. The valleys of Republican, Blue, Nemaha, the Loups, Elkhorn, and Niobrara rivers contain alluvial deposits of moderate width, and all the smaller valleys contain local alluvial materials to a greater or less degree. The deposits are mainly sands and loams, intermixed with pebbles in some localities, and occasionally associated with local beds of clay and accumulations of peat and diato. maceous earth.

Sand dunes.-A wide area of central Nebraska is occupied by wind-blown sands, constituting the great sand-bill district. . Its area is about 24,000 square miles. The sand in this district is blown into high ridges and hills, but there are numerous intersecting valleys of various sizes which constitute a moderate proportion of the area. There are local accumulations of wind-blown sand of considerable extent along the valley of Platte River south of Kearney, along Loup River north of Grand Island, along the south slopes of the North Platte Valley west of the one hundred and third meridian, and in Chase, Perkins, and Lincoln counties.

The sands were largely derived from the Arikaree formation, but it is also probable that they are in part the remains of formations of early Pleistocene age or an extension of the Equus deposits or the loess.

Loess. - The loess occupies more than one-third of the area of Nebraska, usually giving rise to level plains, which it underlies to a thickness of about 100 feet. The widest area is in the table-lands south of Platte River. To the northwest it is overlapped by the sand hills, but it extends far north in the eastern portion of the State and to the southwest to Dundy County. On the divides it is limited on the west by the highlands in Chase and Hayes counties, but extends farther up the valley of Republican River. The western margin in Deuel County is marked by high ridges of Tertiary formations, which constituted a shore against which the loess was deposited. The material of the loess is a fine, sandy loam, somewhat calcareous, and chiefly of a pale brownish-yellow color. Occasionally streaks of sand and old soil are found, and some portions are slightly more argillaceous than usual. The deposit is of a remarkably uniform texture, compact, but perfectly soft. Much of the water falling upon its surface is absorbed, but on steep slopes there is rapid excavation wherever a rivulet gets a fair start. In the lower part of the formation, possibly underlying it, and entirely separate, are deposits of volcanic ash, usually mixed with 
more or less fine sand, but often consisting almost entirely of fine shreds of volcanic glass.

The thickness of the loess is variable, but over a wide area of the central portion of the State it averages 100 feet. It has similar thickness at most points near Mis. souri River. In the region of drift hills about Lancaster County the thickness varies from 20 to 100 feet.

The loess is the product of a relatively long period of deposition at the close of Glacial time. In the wide area in central Nebraska it was deposited by Platte River at a stage when the river spread as a wide plexus of streams over the divide south of its present course. The deposits extend far up the slopes of the high drift hills about Lancaster County, and probably the greater portion of this area was originally entirely covered by earlier loess. Missouri River spread a wide mantle of loess across the eastern margin of the State, and in the later stages of deposition this loess was deposited in the lower, wider valleys among the drift hills.

Drift.-The glacial drift covers the greater part of Nebraska east of longitude $97^{\circ} 30^{\prime}$. It is a product of the Kansan stage of the Glacial epoch, when a lobe of the glacier extended to Kansas River. Extending west from the glacial-drift border there is a thin sheet of sands and gravels, which is continuous under the loess to beyond the one hundred and second meridian. The greater portion of the glacial drift consists of blue and gray bowlder clays. There are locally included sand beds, and in some localities extensive deposits of bowlders. The pink Sioux quartzite, often in very large masses, is a conspicuous feature of the drift, but there are many other rocks associated with it. Wide areas of clay surfaces with only a few scattered bowlders occur, and there are other areas of light sandy clays, particularly on the higher level lands, which appear to be loess merging into the glacial drift. The drift is thick in Lancaster and Gage counties. It thins rapidly toward Missouri River, where it is usually represented by a thin layer of gravel underlying the thick mantle of loess. The thin drift sheet, which extends far west from the glacial-drift margin under the loess, is usually sand or sandy clay, commonly of pinkish color. To the north it is often represented by coarse sand, and to the west it merges into a gravel bed. Pebbles of a great variety of rocks, apparently mainly of Rocky Mountain origin, occur throughout. The westernmost extension of this deposit observed was in the table-land north of Big Spring, in Deuel County, where it is represented by a bed of gravel 20 feet thick underlying 100 feet of loess.

Ogalalla formation.-Extending from Kansas and Colorado far into Nebraska there is a calcareous formation of late Tertiary age to which I wish to apply the distinctive name Ogalalla formation. It is a portion, if not the whole, of the deposit which in Kansas and southward has been called the "Mortar beds," "Tertiary grit," and other names. It has been regarded as a portion of the Loup Fork 


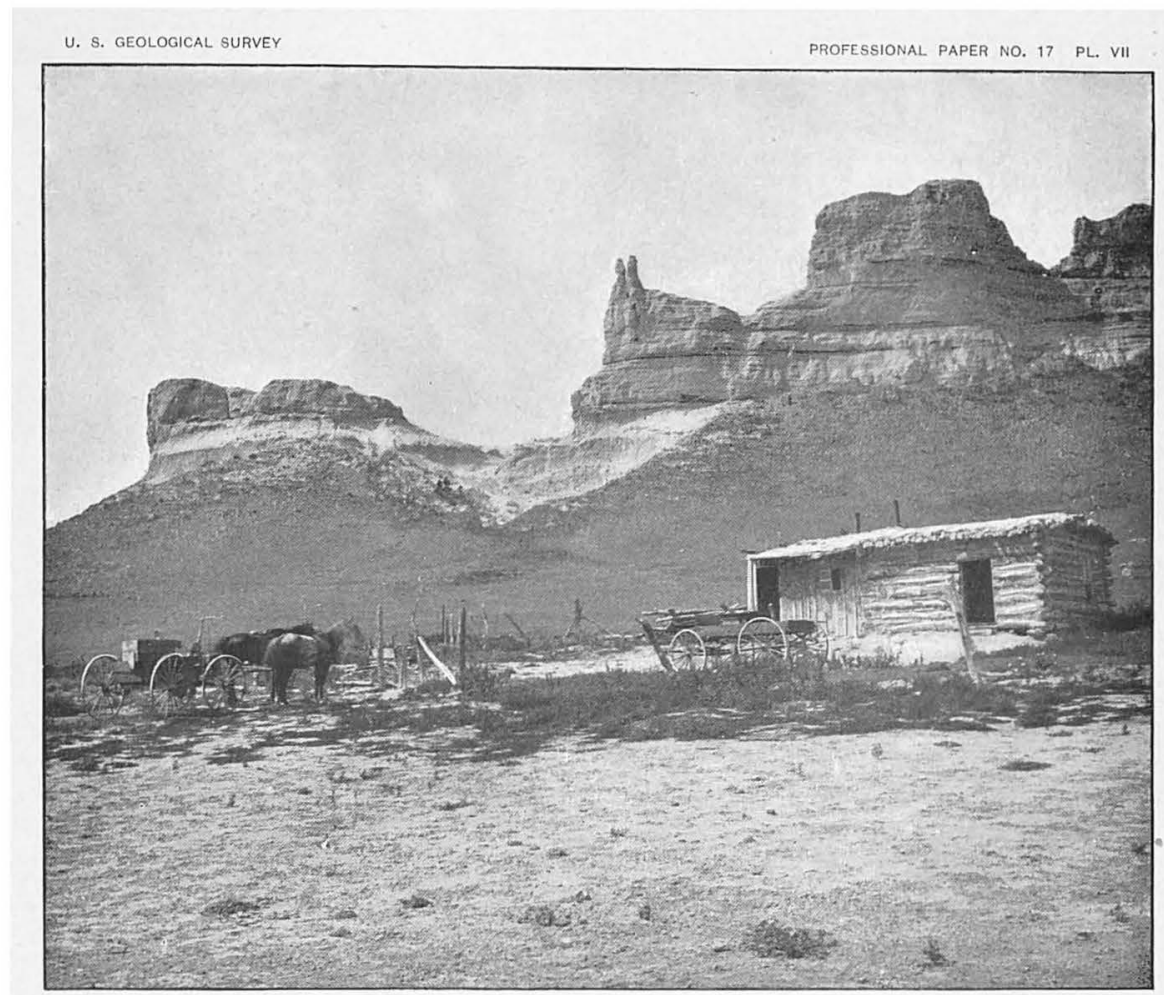

A. "TWIN Sisters," BanNer COUNTY, Nebr.

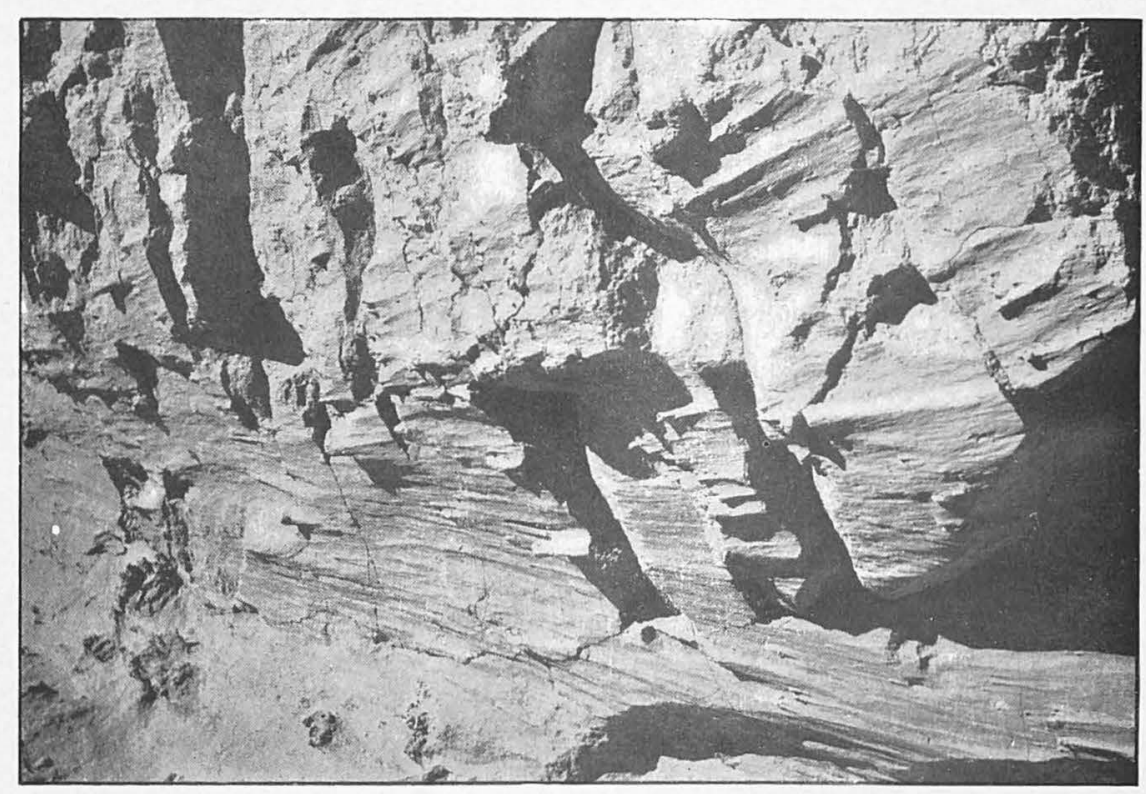

b. WIND EROSION IN GERING FORMATION, BANNER COUNTY, NEBR. 



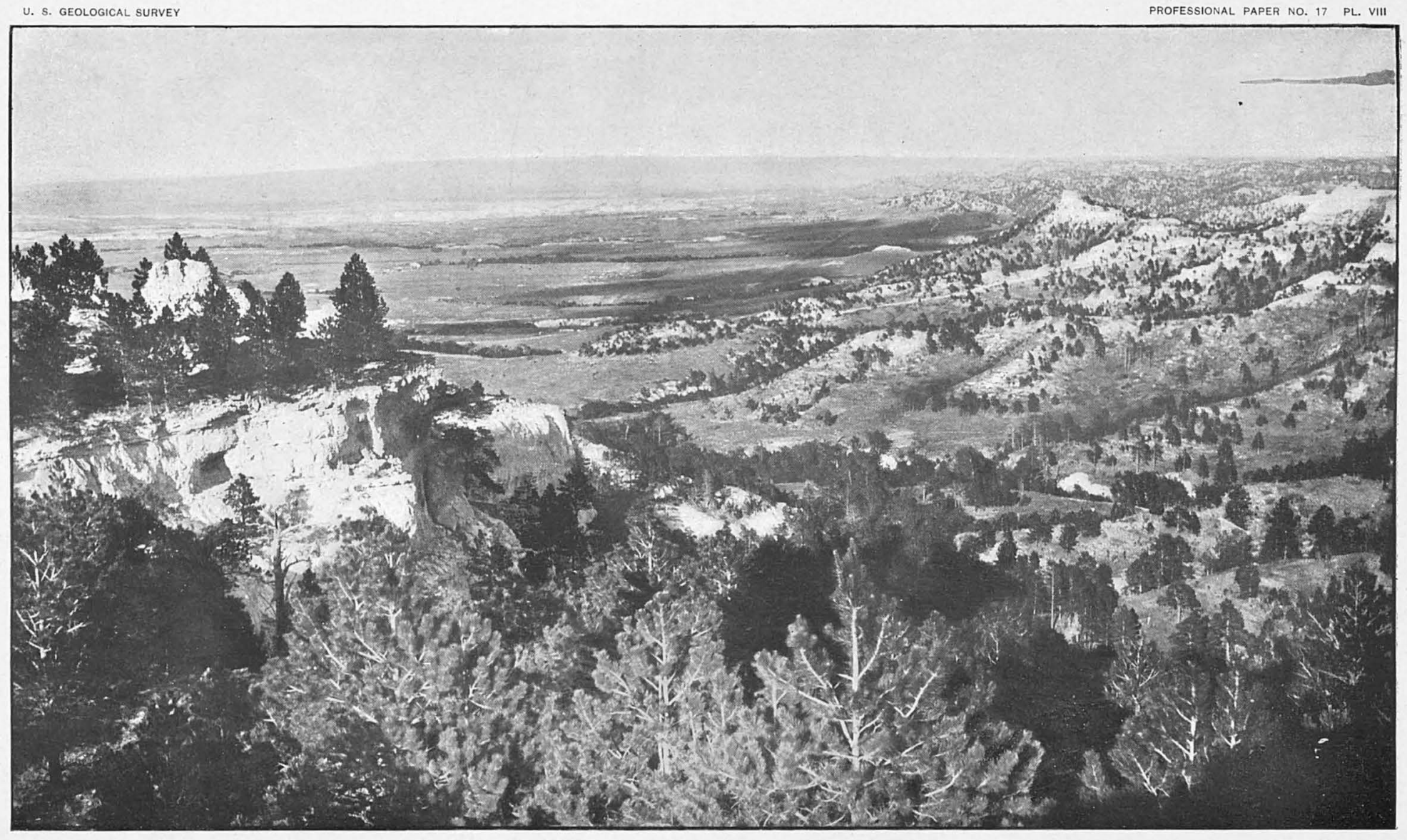

NORTH FACE OF PINE RIDGE, LOOKING NORTHEAST OVER HAT CREEK BASIN

Showing cliffs of Arikaree formation. Badlands in Brule clay in the distance. (From photograph by E. H. Barbour, University of Nebraska.) 

formation. It is extensively developed in the western part of Nebraska, in the region about Lodgepole Creek and in the area between Platte River and the Kansas line west of the ninety-ninth meridian. It thins out in Banner County and in the central part of Cheyenne County, giving place to the northwest to an underlying member of the Loup Fork series. It crosses North Platte River.in the western part of Deuel County, but its limits in the central and northern portions of the State have not been ascertained. It appears to underlie a portion at least of the great sand-hill district. In its typical development the Ogalalla formation is a calcareous grit or soft limestone containing a greater or less amount of interbedded and intermixed clay and sand, with pebbles of various kinds sprinkled through it locally, and a basal bed of conglomerate at many localities. In places it merges into a light-colored sandy clay, generally containing much carbonate of lime in streaks or nodules. The pebbles it contains comprise many crystalline rocks, which appear to have come from the Rocky Mountains. These pebbles accumulate on the disintegrating surfaces of the Ogalalla formation, and they appear to have contributed largely to the gravel bed underlying the loess to the east.

Arikaree formation.-In the western portion of Nebraska there is found underlying the Ogalalla formation a series of sands of gray color everywhere characterized by layers of dark-gray concretions which often have tubular form. This formation enters the State from Wyoming, and has been found to thin out under the Ogalalla formation in the eastern portion of Banner County. It has a thickness of 400 feet in Scotts Bluff County and of 500 feet in Sioux and Dawes counties, the amount increasing as the Arikaree displaces the Ogalalla formation northward. It is extensively exposed along Niobrara River, apparently to the east of Valentine, and it is seen occasionally along the western edge of the sand-hill district, but it has not yet been distinctly recognized in the region drained by the Loup Forks or along Platte River east of Cheyenne County. In its upper portion are beds containing the large Dixmonelix of Barbour. The name Arikaree bas been applied to the deposit for the reason that the Arikaree Indians were at one time identitied with the area in which it is most largely developed. It is distinctly separated from the Ogalalla formation by erosional unconformity and overlap, which is clearly illustrated in the western portion of the State. The formation includes a large amount of volcanic ash, as a general admixture in its sediments as well as in beds of considerable extent and thickness. It also contains a number of channels filled with conglomerate, which will be described in detail later. (See p. 28.)

Gering formation.-This formation, like the Arikaree and Ogalalla formations, was differentiated in the summer of 1897. It consists of laminated, massive, and cross-bedded, light-gray, mainly coarse sands and soft sandstone at the base of the Arikaree formation. The character of the deposits and the abrupt change from

14478-No. $17-03-2$ 
the typical Arikaree formation have afforded a basis for the discrimination of this formation. It has been found in Scotts Bluff, Banner, Cheyenne, Sioux, and Dawes counties, and locally attains a thickness of 200 feet. It often comprises two members, more or less distinctly separated by unconformity, and it lies unconformably on the Brule clay. The materials are sands, which vary from coarse to fine, and they are often sufficiently lithified to be classed as soft sandstone. At the base there is usually more or less conglomerate of local origin. In some districts the formation thins out and appears to be entirely absent, but possibly in this case it has simply lost its distinctive characteristics, so that it would be overlooked as the lower portion of the Arikaree formation. In some cases where the formation is thought to be absent there is seen to be unconformity below the Arikaree beds.

Brule clay.-The White River beds in their extension from South Dakota into Nebraska present some differences in stratigraphic range and relations. They expand considerably and include, at their top, beds which appear not to be represented in the typical regions. Accordingly, to afford distinct definitions for the members in Nebraska; I have introduced the designation Brule clay, and separated the underlying Titanotherium beds as the Chadron formation.

The Brule clay consists mainly of a hard, sandy clay, of pale-pink color. Its thickness averages about 600 feet in the vicinity of the Wyoming line, but the amount diminishes greatly eastward. In the vicinity of the one hundred and third meridian in the northwest corner of the State it has a thickness of 320 feet. The formation has not been recognized east of longitude $101^{\circ} 30^{\prime}$, where it appears to sink beneath the surface in the Platte Valley. It extends far to the northeast in South Dakota.

Chadron formation.-Lying under the Brule clays there is a thin sheet of lightgreenish, sandy clay, the basal member of the White River series, known as the "Titanotherium beds." Its outcrops extend in a narrow zone across the northern portion of the State, and it is apparently exposed along North Platte River near the Wyoming line. It is known to underlie portions of Colorado and South Dakota, but it appears not to extend far eastward in southern Nebraska, for it is absent along Republican River. It is reported that Titanotherium remains were obtained near Longpine, but nothing has been learned of the relation and extent of the beds in that locality.

Laramie formation. - The Laramie formation extends under the southwestern corner of Nebraska, but probably to no great distance. Its only exposures are along the State line on Horse Creek west of Caldwell and in another small area a few miles southwest of that place, where it rises in a low mound under the Brule clay. The rocks are yellowish and greenish sandstones and clay.

Pierre clay.-All of Nebraska west of the ninety-eighth meridian is underlain by the Pierre clay. Its surface outcrops are in the lower portion of the Niobrara Valley, 



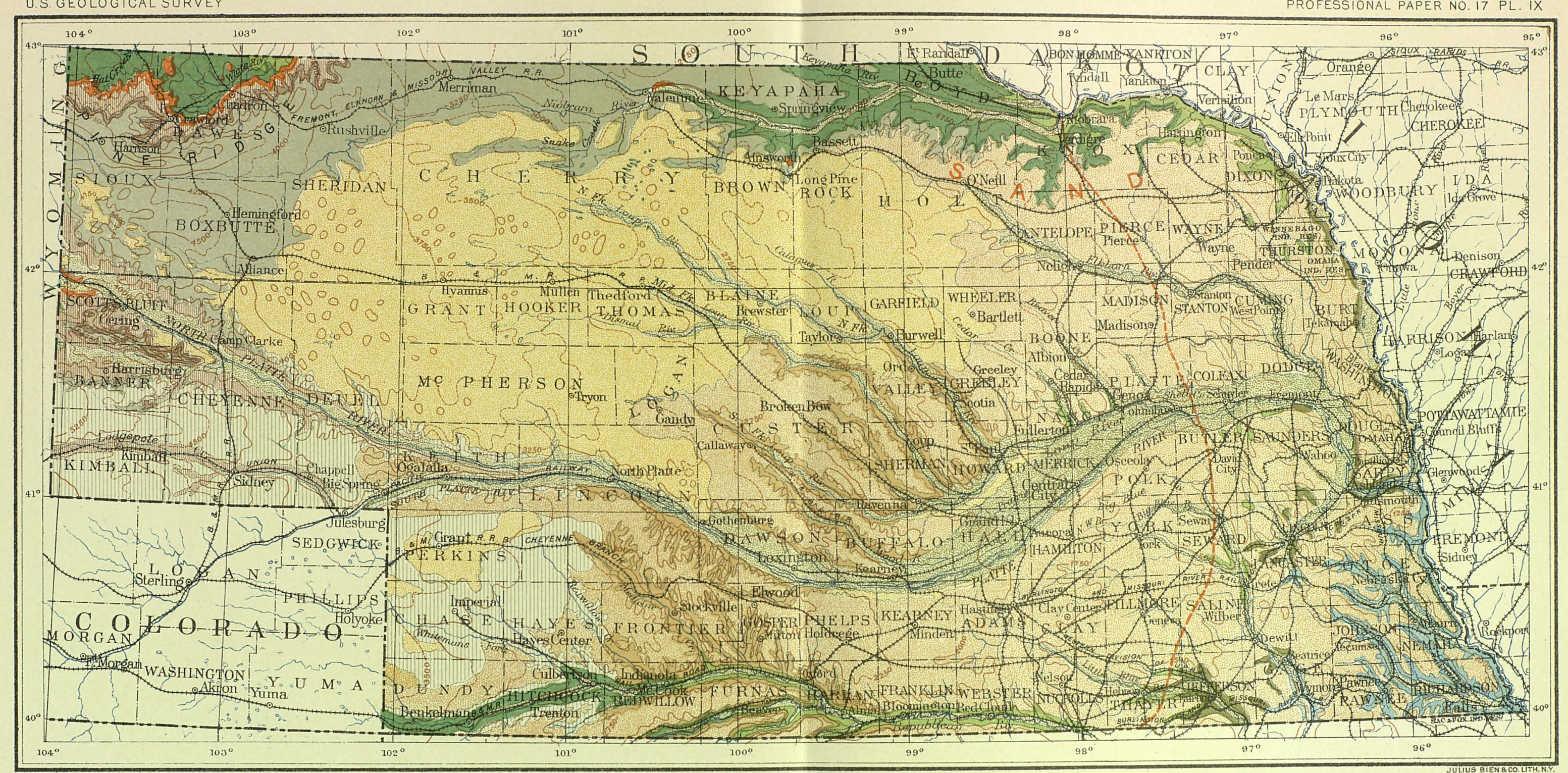

PRELIMINARY GEOLOGIC MAP OF NEBRASKA, BY N. H. DARTON

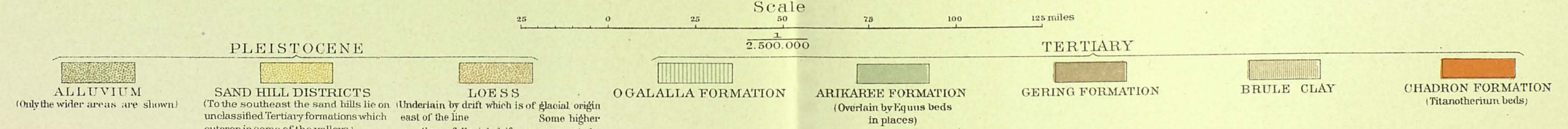
east of the line
portions of lacial drif area appear to be
bare of loess

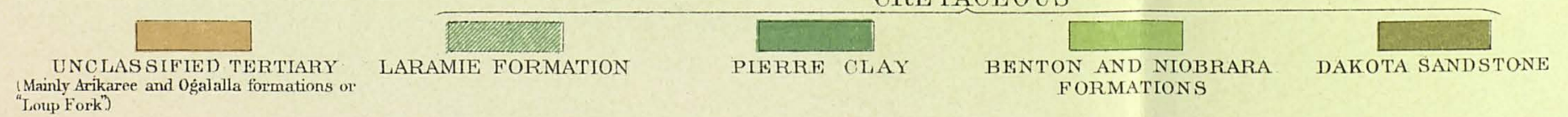
PERMIAN SERIES 



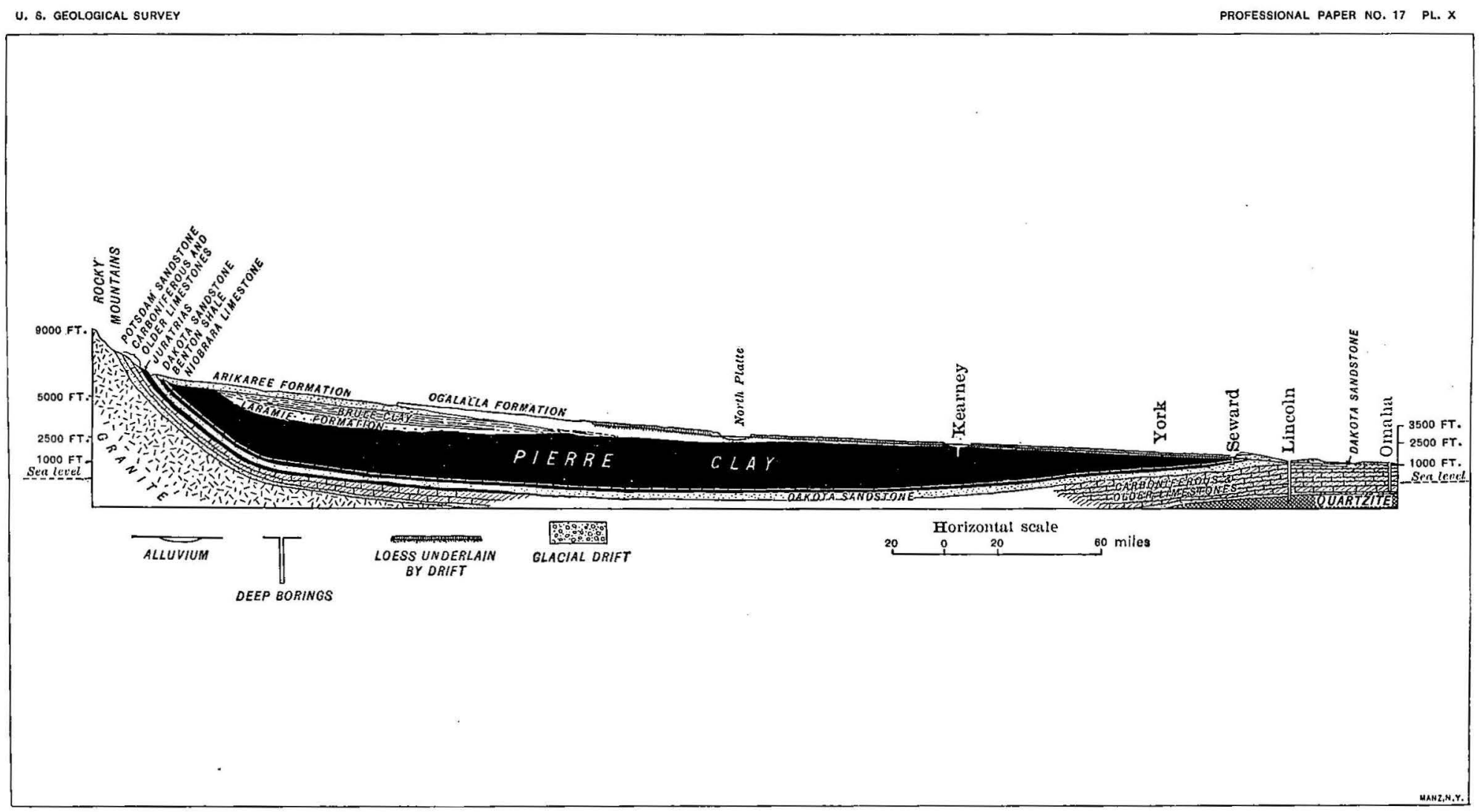

CROSS SECTION FROM ROCKY MOUNTAINS TO OMAHA, ACROSS NEBRASKA. 

the Republican Valley, and the extreme northwest corner of the State, but it is probable that careful search will reveal outcrops in the valley of the Platte River in the vicinity of the ninety-sixth meridian. The formation is a thick mass of darkgray or bluish clay or soft shale. Its thickness is probably at least 2,000 feet in the central-western portion of the State.

Niobrara and Benton formations.-Underlying the Pierre clay there is a series of chalky limestones known as the Niobrara formation and shales known as the Benton formation. They have a thickness of about 450 feet to the east, but thicken to the west. At the base there are about 200 feet of dark shales, overlain by slabby limestones of the Greenhorn formation containing Inoceramus, which are followed by a series of shales with few thin sandy layers, and at the top the Niobrara formation with its chalky deposits characterized by thin hard beds filled with Ostrea congesta. The formations cross the eastern portion of the State, and underlie all of the area west of the vicinity of the ninety-seventh meridian, but they are so deeply buried under drift and loess that outcrops are rarely visible. The most extensive exposures are along Missouri River, extending from near the ninety-seventh to the ninety-ninth meridian, and along the Republican Valley from Alma to near Superior. The formations are exposed at intervals across the eastern portion of the State in each of the larger valleys and some of the branches. The more notable of these small outcrops are at Genoa, north of Germantown, near Crete, at Pleasant Hill, and in Beaver Creek north of Dorchester. There is an exposure of dark shales under some ledges of Greenhorn limestone in Big Blue River at Milford, which are Benton. During the summer of 1897 upper Benton and Niobrara beds were discovered rising in a prominent anticline along White River in the vicinity of Beaver and Alkali creeks, in the northwest portion of the State.

Dakota sandstone.-The Dakota sandstone underlies nearly all of Nebraska, and outcrops in a narrow belt extending from Missouri River to the vicinity of the ninety-seventh meridian. It is gray or brown sandstone, containing streaks of clay of greater or less size, and its aggregate thickness is about 400 feet, including a basal series of Lower Cretaceous sandstone. Its surface passes under the Benton shales, and, owing to the low westerly dip and the gradual increase in altitude of the State to the west, the Dakota sandstone is soon deeply buried. In the central portion of the State it probably lies over 2,500 feet below the surface. In its outcrop area it is heavily covered by drift and loess, but there are numerous exposures in the banks along Missouri River in Dakota County-which was the type locality of the formation - along Platte River from Ashland nearly to Plattsmouth, along the valley of Salt Creek and its branches, at Beatrice, and in the valley of Little Blue River in Jefferson County. The formation carries the great artesian-water supplies, which are so extensively developed by wells in eastern South Dakota and on lowlands in Knox, Cedar, and Boyd counties, Nebraska. 
Carboniferous formations. - The Carboniferous limestones, shales, and sandstones underlie all of Nebraska, rising to the north and northwest abo the Black Hills and on the slopes of the Rocky Mountains, as shown in Pl. X and fig. 21, on page 46. The outcrops in eastern Nebraska are in Douglas, Sarpy, Cass, Lancaster, Otoe, Gage, Johnson, Pawnee, Nemaha, and Richardson counties. The rocks are hard and would give rise to more prominent features in this region if it were not for the heavy covering of glacial drift and loess. As it is, the exposures constitute cliffs along Platte River from Ashland to Plattsmouth, and thence at intervals along Missouri River to the southeast corner of the State, and occur in scattered outcrops along the valleys of Big Blue, Nemaha, and Little Nemaha rivers and Weeping Water, Turkey, and Southeast Salt creeks and their branches.

The rocks of the Carboniferous period in this region comprise formations of Permian and Upper Coal Measure or Pennsylvanian age. The Permian outcrops are probably restricted to the valley of Big Blue River from Beatrice southward. The rocks are mainly magnesian limestones of light color with interbedded shales. They are extensively exposed south of Beatrice, at Rockford, Blue Springs, Wymore, and Holmesville. The other Carboniferous members appear to comprise the Cottonwood and Wabaunsee formations of the Kansas geologists. They consist of limestones, shales, and sandstones, which contain thin coal beds in some localities. Professor Prosser has made a preliminary examination of the Carboniferous of Nebraska, and identifies as Wabaunsee the exposures about Peru, Aspinwall, Nebraska City, Auburn, Tecumseh, Dunbar, Nehawka, Weeping Water, and in the long section along Platte River near Louisville. The Cottonwood limestone, a massive bed full of Fusulina, was recognized west of Auburn about Glen Rock and Johnson, and the same beds extend over the higher lands of western Richardson and Pawnee counties. ${ }^{a}$ In the deep borings which have been made at various points in the southeastern corner of the State it has been found that the Carboniferous formations have a total thickness of about 1,200 feet, of which about 200 feet are Permian. In the deep well at Lincoln the lower limestones were found to be 835 feet thick and underlain by 800 feet of magnesian limestones of undetermined, but probably in part Devonian, age; these, in turn, by limestone apparently of the Trenton formation, extending from 1,813 to 1,947 feet; a supposed representative of the St. Peter sandstone, having a thickness of 61 feet; 113 feet of magnesian limestones, supposed to be the Magnesian limestone of the Mississippi Valley; and a red sandstone, extending from 2,121 to 2,192 feet, thought to be Cambrian. This was found to lie on a red quartzite-penetrated for 270 feet-supposed to be an extension of the Sioux Falls quartzite of Algonkian age, which is underlain by granite rocks northward.

a Jour. Geol., vol. 5, 1897, pp. 1-16. 



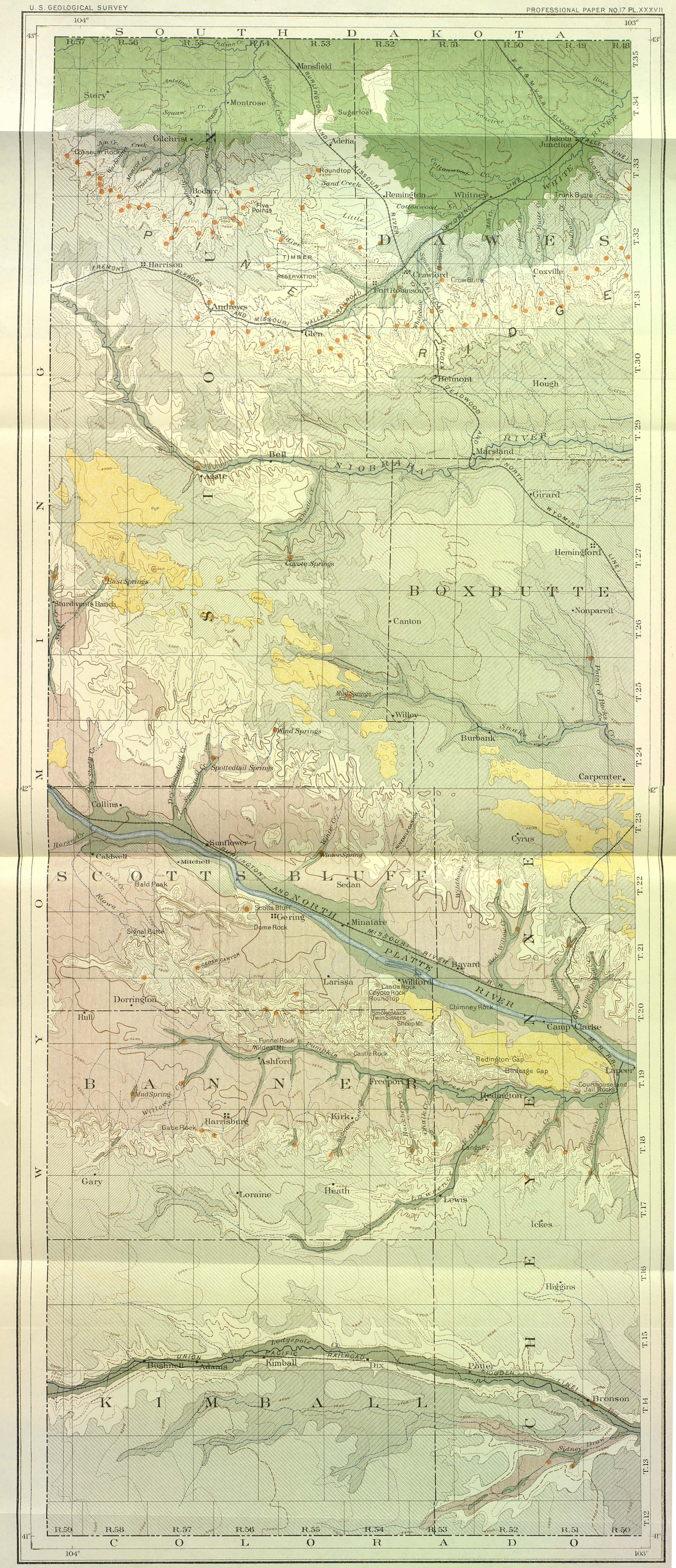

MAP SHOWING DISTRIBUTION OF UNDERGROUND WATERS IN NEBRASKA

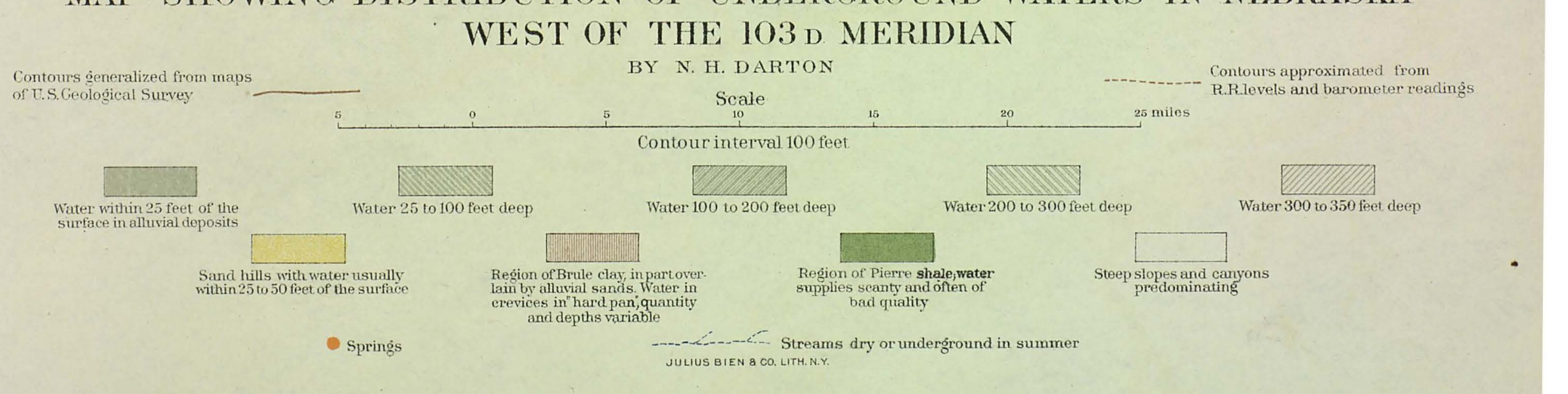






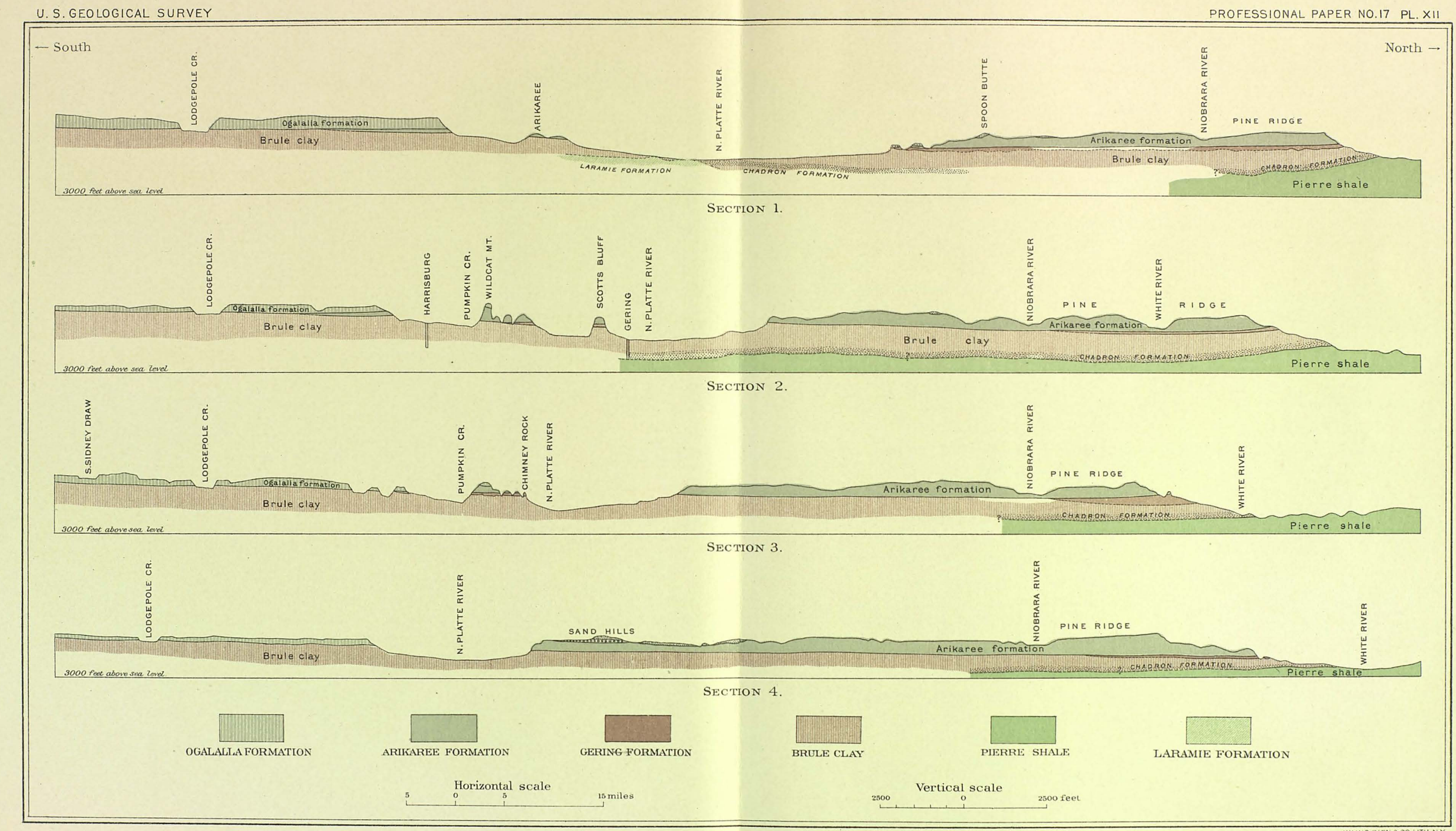

GEOLOGIC SECTIONS ACROSS NEBRASKA WEST OF THE 103 ${ }_{\text {D }}$ MERIDIAN, LOOKING WEST ALONG THE LINES 1, 2, 3, AND 4, ON PLATE XI.
BY N.H.DARTON, 1898 

There are possibly two other formations underlying portions of Nebraska but not reaching the surface. To the northwest there is doubtless an extension of the Juratrias red sandstones and greenish sands and clays which are exposed so conspicuously about the margin of the Black Hills, only $\breve{5} 5$ miles distant from the northwest corner of the State. They lie between the Carbonfferous limestone and the Dakota sandstone, as shown in the sections, Pl. X and fig. 21, on page 46. They are absent in the eastern portion of the State, but in part are extensively developed in Kansas.

The other formation which may extend into Nebraska is the Laramie sandstone, which lies between the Pierre shale and the Tertiary formątions in northeast Colorado. It would not be surprising if this formation should be found to underlie a portion of extreme western Nebraska, but it is known to be absent in the Republican Valley as far west as Dundy County, and in the region north of Pine Ridge, in Sioux and Dawes counties.

\section{GEOLOGY OF THE REGION WEST OF THE ONE HUNDRED AND THIRD} MERIDIAN.

GENERAL RELATIONS.

The formations of this region comprise alluvium and dune sands and Ogalalla, Arikaree, Gering, Brule, and Chadron formations, lying on a thick mass of Pierre clay and the northeastern edge of the Laramie formation. The loess and drift are not present. The distribution of these formations, except the alluvium, is shown on the geologic map, Pl. XI. Their structural relations are shown in the series of cross sections, Pl. XII. The older formations underlying the Pierre shaie do not reach the surface nearer than the southern slopes of the Black Hills, where, as shown in fig. 21, they rise in regular succession.

The relations of the formations, as shown in Pls. XI and XII, are relatively simple. There is a broad, thick sheet of Brule clay, underlain by a thin layer of Chadron formation, lying on the irregular surface of the Pierre clay, which outcrops in the region north of the foot of Pine Ridge. The Gering formation is a thin sheet of coarse sand and soft sandstone which lies on the Brule clay, mainly in channels. It appears to outcrop continuously along the northern front of Pine Ridge, about halfway up the slope; it has been recognized at one point on the north slope to the valley of North Platte River. It is extensively developed in wide channels in the ridge lying next south, but it is absent in the table-land south of Pumpkinseed Creek, except probably in a small outlier exposed far up the valley of Lawrence Fork. The Arikaree formation, consisting of fine sands with dark-gray pipy concre. tions, constitutes the crest of Pine Ridge and the table-land extending north of the Platte Valley. It also heavily caps the ridge lying between the valleys of the Platte 
and the Pumpkinseed, but it thins rapidly to the south and east in the high table-land south of the Pumpkinseed Valley, and dies out east of the mouth of Lawrence Fork. The Ogalalla formation, consisting mainly of light-colored pebbly sands cemented by carbonate of lime, covers the table-land south of the Pumpkinseed Valley, lying on the Brule clay to the east and on a thickening wedge of the Arikaree formation to the west. . Outlying masses cap certain high points on the ridge north of the Pumpkinseed Valley, and it may possibly be present on the higher portions of the tableland north of Platte River, together with outliers of the Equus beds. The larger sand-hill areas are on the table-land north of the valley of Platte River, but smaller areas are found in both Platte and Pumpkinseed valleys. Alluvium, which is not represented on the map and sections, floors portions of the valleys and merges upward into wash and local talus on the slopes of the hills.

\section{ALLUVIAL FORMATIONS.}

On the lower slopes adjacent to North Platte River and along the other streams of the region there has been deposited a greater or less thickness of materials brought by the streams.from the higher lands. In the valley of Platte River thẹre is a wide zone of bottom lands bordering each side of the river, on which is found a mantle of alluvium, several feet thick, lying on the older formations in which the river valley was cut. The materials consist mainly of sandy loams with occasional coarse constituents. On the adjoining terraces above is found a mantle of sand and gravel, deposited when the river was much higher than it is now. The gravels : contain many rocks from the Rocky Mountains, comprising granites of various kinds, quartzites, chalcedonic vein stones, often of considerable beauty, and a small variety of eruptive rocks. The materials vary in size from coarse sand to moderately large bowlders. The coarser deposits give rise to long narrow ridges or lines of knobs, while the materials of intermediate coarseness cover terraces, which in some cases extend back from the river bottom for several miles. It is claimed that small showings of gold have been panned from these formations at several localities. In the valleys of Lodgepole and Pumpkinseed creeks and White River the alluvial materials are mainly in narrow belts of bottom lands, and consist chiefly of local materials. In the valley of Pumpkinseed Creek, however, there are at higher levels extensive deposits of coarser gravels containing rocks from the Rocky Mountains similar to those along Platte River. It is probable that this river at one time sent a branch stream through the wide depression now occupied by Pumpkinseed Creek and spread the gravel on the high terraces. At that time the ridge lying north of Pumpkinseed Creek was an island in the midst of a wider Platte River, but the valleys were not so deep as they are now. Nearly every stream flowing out of the high lands has brought down more or less alluvial material in the shape of sand or local gravel, which merges into the alluvial deposits of the larger valleys. There 


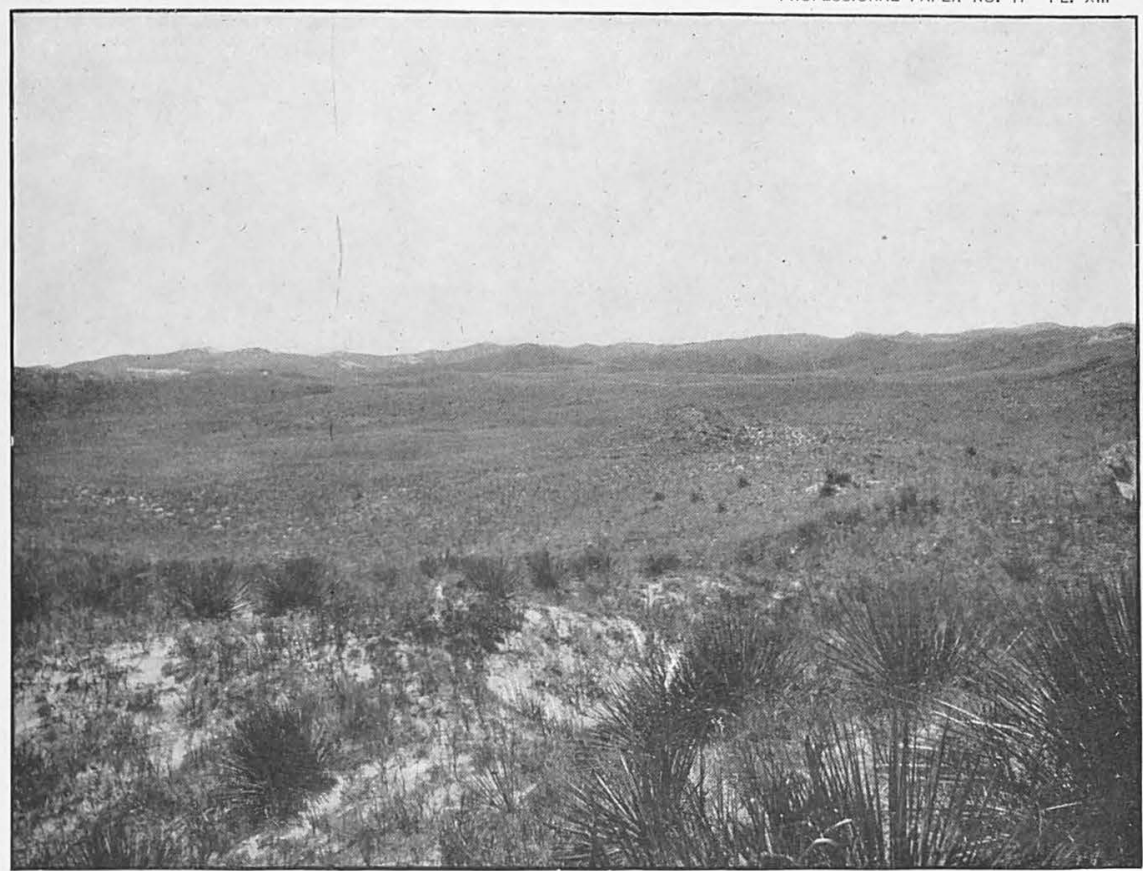

$A$.

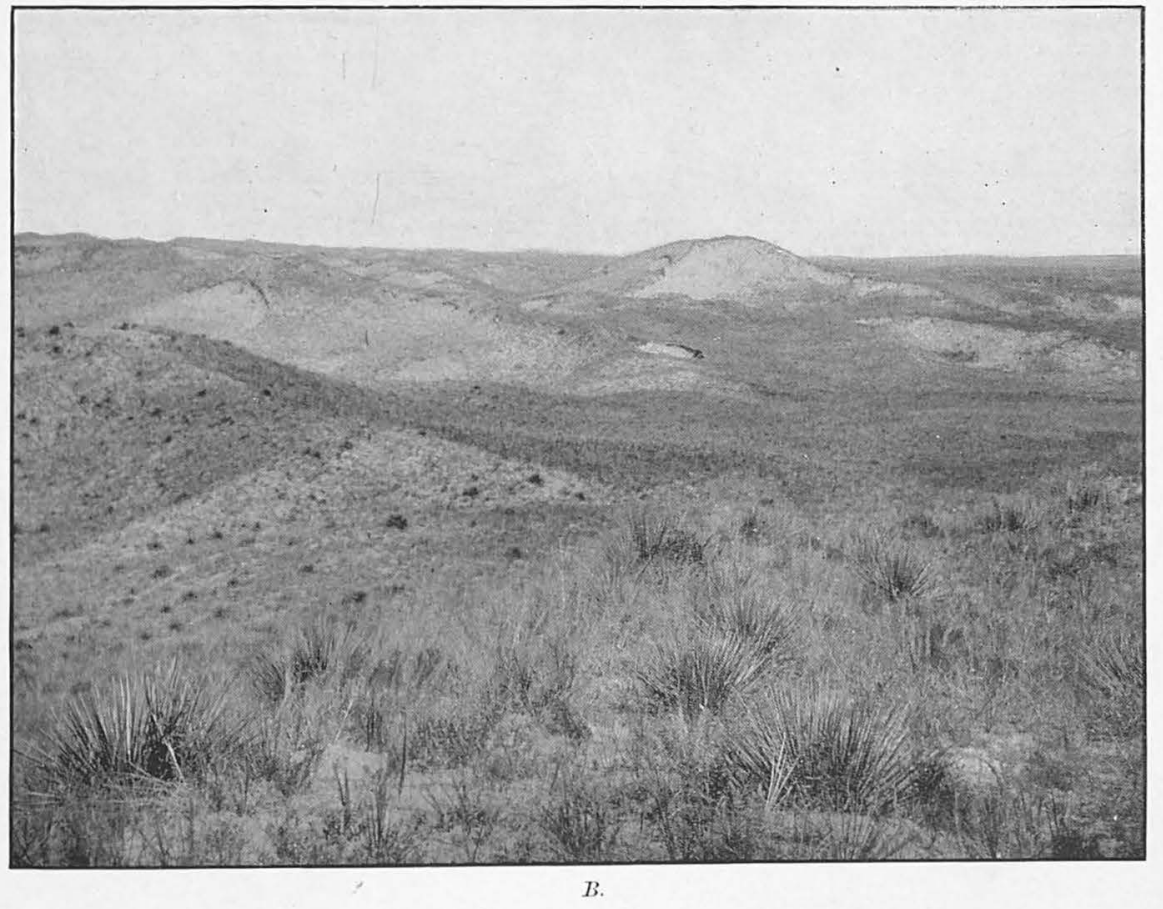

TYPICAL SANDHILLS IN WESTERN CHEYENNE COUNTY, NEBR.

4 Leeward side, looking west; $B$, windward side, looking southeast, showing blowouts. 

is also on nearly all of the slopes adjoining the valleys a talus or wash of sand and clays from above, which often covers the underlying formations to considerable thickness.

None of the alluvial formations have been shown on the geologic map, PI. XI, because some of their relations are too intricate for accurate representation on a small scale.

SAND DUNES.

The sand hills are a distinct geologic formation in this region, in part contemporaneous with the alluvial deposits along the bottoms of river valleys. They are in process of formation and modification by the strong winds, and are in a measure still moving to the southeast. Two typical views of the sand-hill region are reproduced in Pl. XIII. The sand now constituting the sand hills was derived mainly from the Arikaree formation, having been carried over the plains by the wind and accumulated about the obstructions. The manner in which the sand is blown away is well illustrated in Pl. XVIII, $A$. . The sand-dune areas in the North Platte Valley no doubt derived a portion of their material from the sand banks and other alluvium of the river which have been blown by the wind and lodged against obstructions. This is particularly well illustrated in the area which abuts against Chimney Rock. The small areas about Caldwell and Dorrington and at other points in the Pumpkinseed Valley are probably of similar origin, except in a few cases where local sources have supplied the materials.

OGALALLA FORMATION.

The Ogalalla formation is the uppermost division of the Tertiary deposits of this region. It constitutes the high table-lands on both sides of the Lodgepole Valley, and caps the several small high summits about Wildcat Mountain, northwest of Ashford. As before explained, it is in the main the extension of the "Tertiary grit," "Magnesia," or "Mortar beds" of the Kansas geologists. It consists of an impure calcareous grit, or sand cemented with carbonate of lime. At its base there are often beds of conglomerate, with pebbles consisting mainly of gray sandstone or limestone. Throughout its mass there are scattered pebbles of crystalline rocks from the Rocky Mountains, streaks of pebbly sand, and thin ledges of sandstone. The harder calcareous beds are of white or cream color, and outcrop in irregular cliffs along the slopes of depressions. Some softer intercalated beds of sandy character are of light-pinkish color. The formation has a relatively level surface, which constitutes the floor of the high table-land of Kimball County and the southern portion of Banner and Cheyenne counties. When the rock disintegrates on the surface a greater or less accumulation of sand and scattered pebbles remains, often constituting a soil of greater or less thickness. This soil, when irrigated, usually proves to be very productive. The general thickness of the Ogalalla formation 
varies from 150 to 300 feet, the greater amount being along the Wyoming line, in the northwest corner of Kimball County. As the surface has been more or less eroded, the original thickness is unknown. The altitude of its base is 4,100 feet south of Lapeer, 5,200 feet west of Harrisburg, 4,300 feet near Bronson, 5,100 feet west of Bushnell, and 5,000 feet on Wildcat Mountain. The wider relations of the Ogalalla formation to the older Tertiary formations are shown in the cross sections in PI. XII. In these sections it will be seen that in Lodgepole Valley the Ogalalla formation lies directly on the Brule clay; along the south side of the

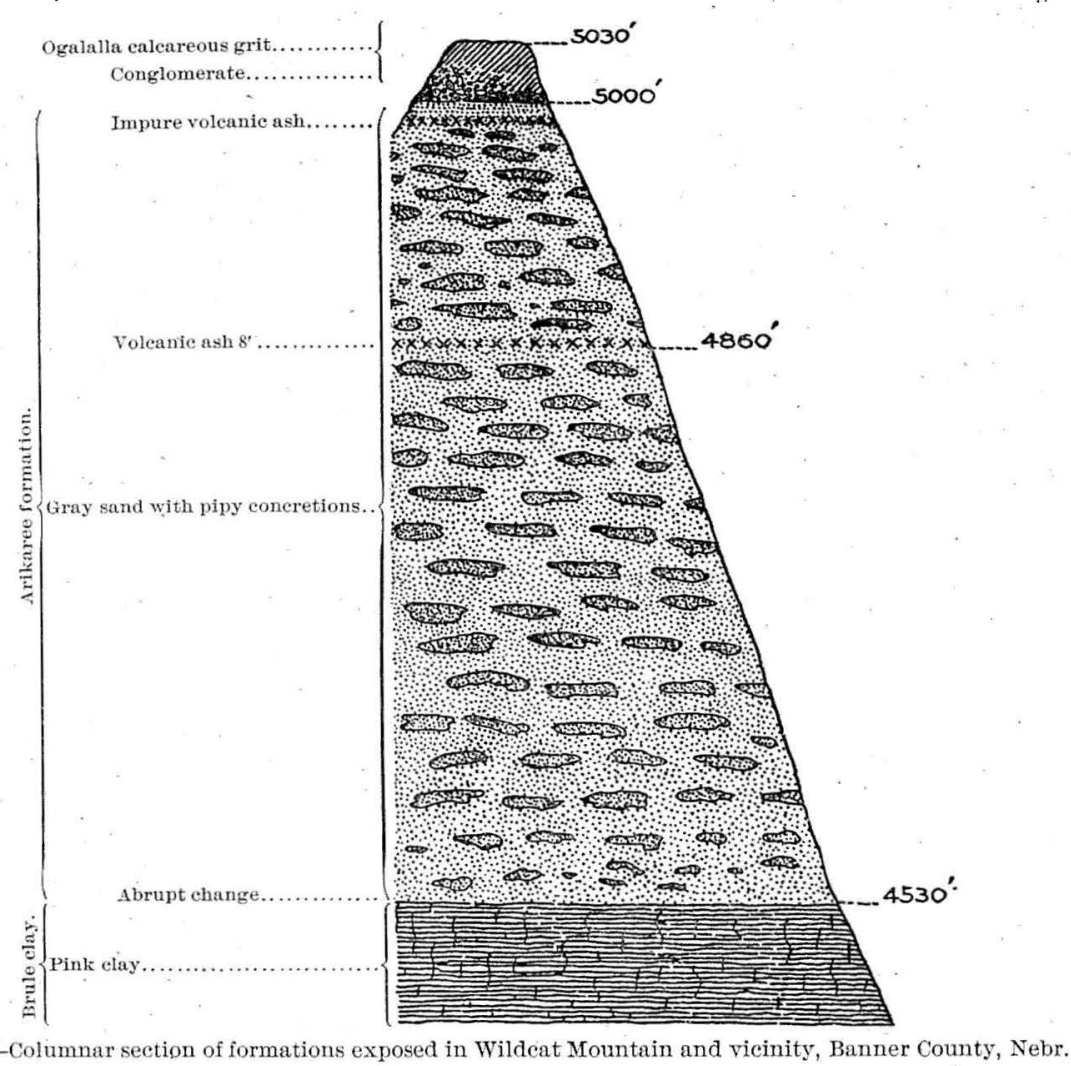

Pumpkinseed Valley it lies on the Brule clay to the east, and then on the Arikaree formation, which comes in and gradually thickens to the west. An exposure of its basal conglomerate is shown in Pl. XIV. At this exposure the Arikaree beds are thin, as shown in $\mathrm{Pl}: \mathrm{XV}, C$. It is everywhere clearly separated below by erosional unconformity, and its base is usually a shore deposit of pebbles of gray siliceous and calcareous rocks. In the outliers about Wildcat Mountain the thickness is about 50 feet, and the formation lies on a thick mass of Arikaree formation, from which the basal conglomerate is very distinctly separated by an unconformity. The relations in this vicinity are shown in fig. 1. 


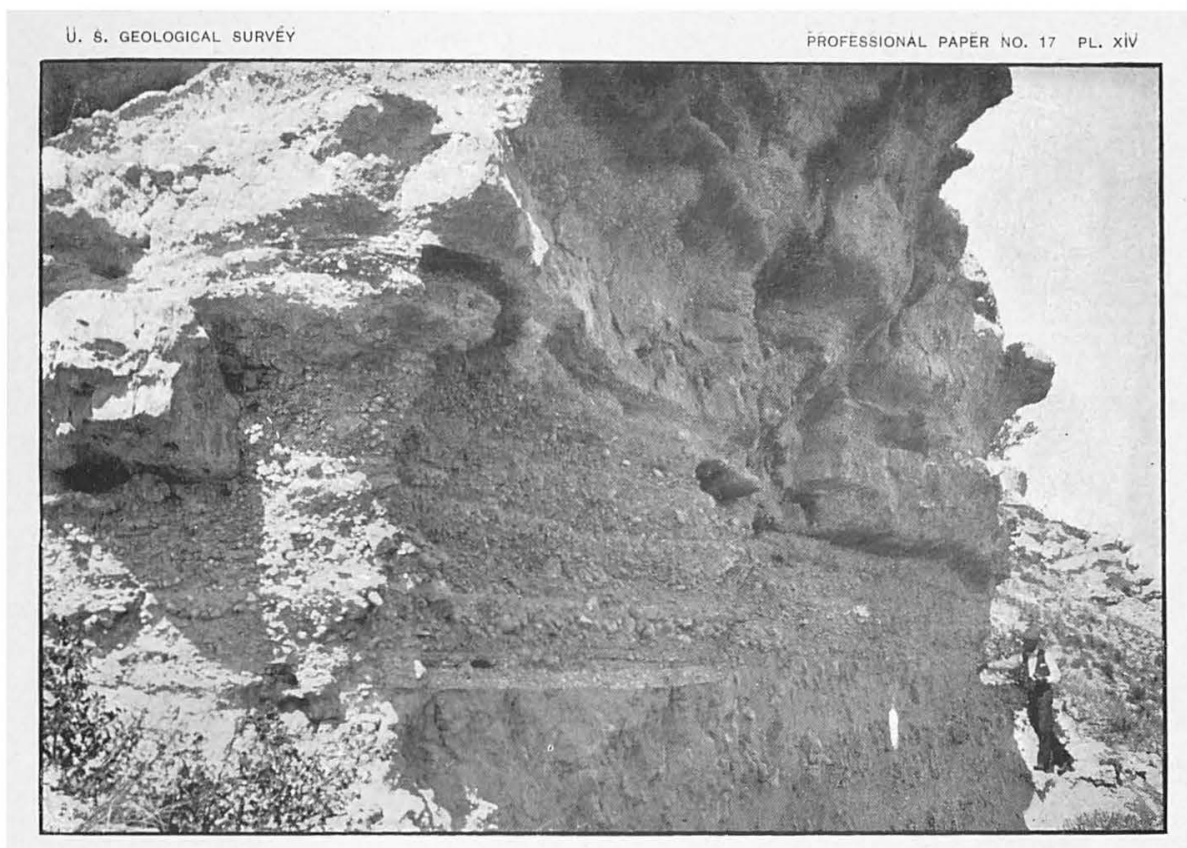

A. CONGLOMERATE AT BASE OF OGALALLA FORMATION 5 MILES SOUTH-SOUTHEAST OF REDINGTON, CHEYENNE COUNTY, NEBR.

The conglomerate lies on Arikaree formation.

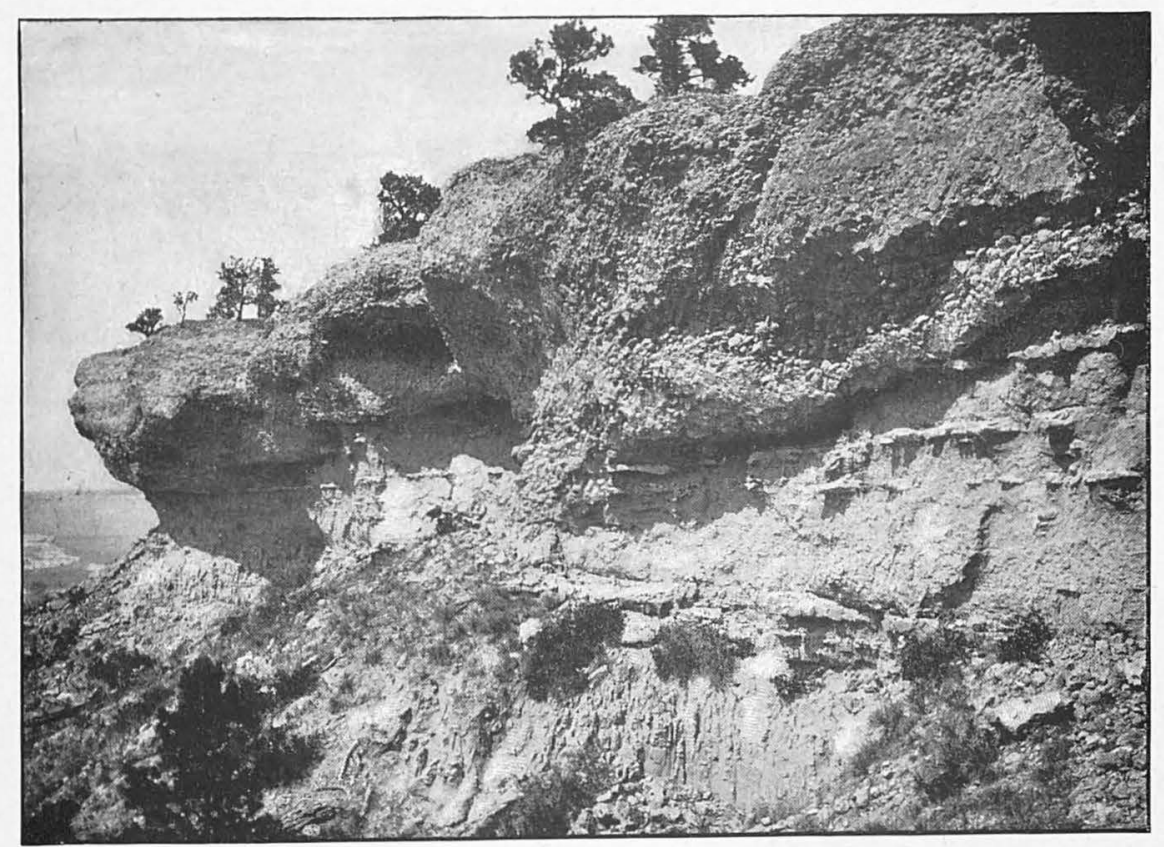

B. CONGLOMERATE IN ARIKAREE FORMATION 3 MILES DUE SOUTH OF LARISSA, SCQTTS BLUFF COUNTY, NEBR.; LOOKING NORTHWEST. 



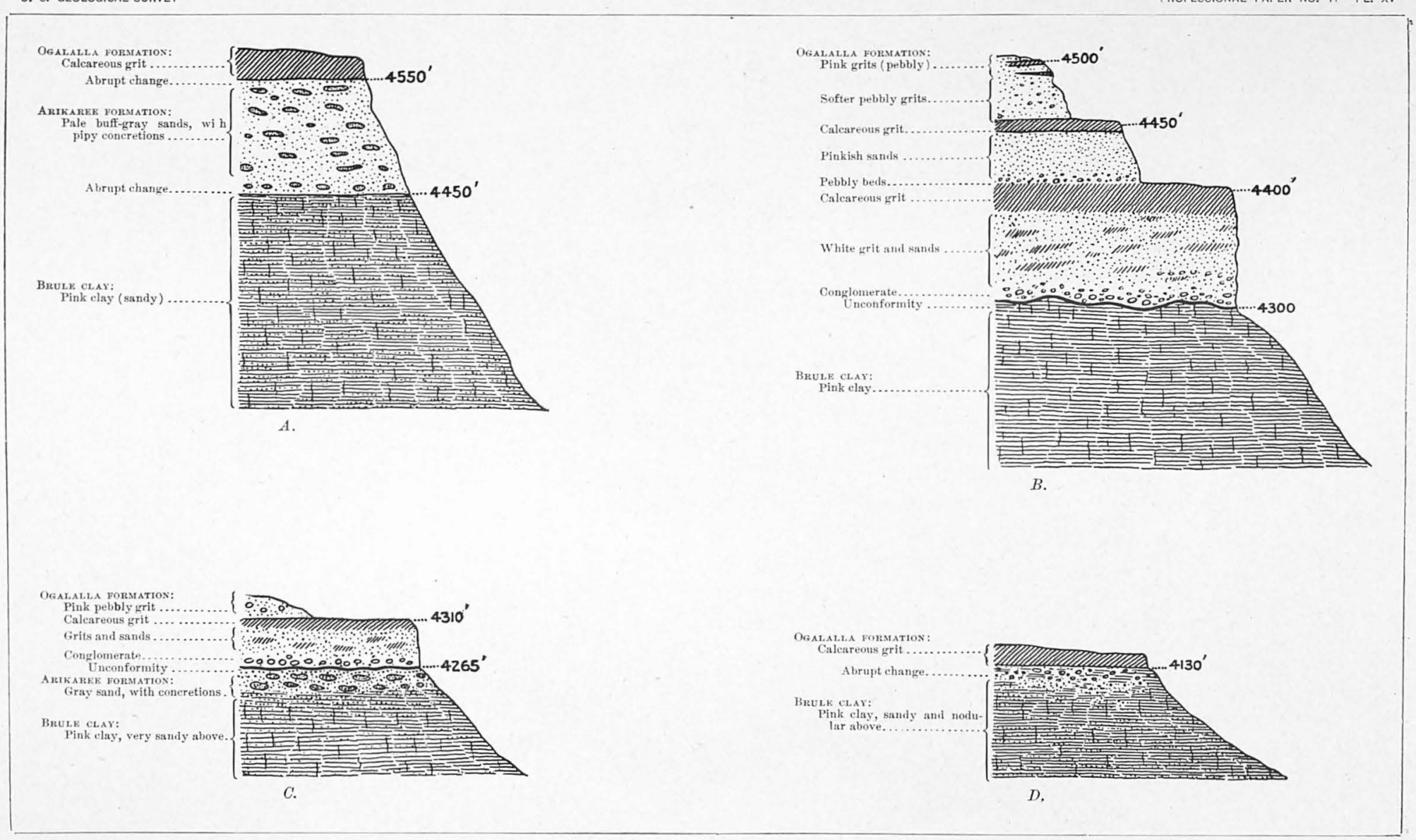

SECTIONS OF EXPOSURES OF ARIKAREE AND OGALALLA FORMATIONS AT AND NEAR LANGS POINT, NEBR.

$A, 8$ miles west of Langs Point; $B$, at Langs Point; $C, 5$ miles east of Langs Point; $D, 10$ miles east of Langs Point. 

Some typical sections illustrating the relations of the formations are given in Pl. XV. There may possibly be a small area of Ogalalla formation to the east on portions of the table-land north of North Platte River, but it was not distinguished. A few vertebrate remains were collected in this formation, and it was found to contain the smaller Drmonelix forms in considerable abundance in some localities.

ARIKAREE FORMATION.

The Arikaree formation attains its greatest development in Pine Ridge, where it presents a thickness of about 500 feet. It constitutes a wide area of table-land extending from Pine Ridge to the northern margin of the valley of North Platte River. It occupies the ridge lying between the valleys of North Platte River and Pumpkinseed Creek, and to the southwest it is exposed in the slopes of the table-

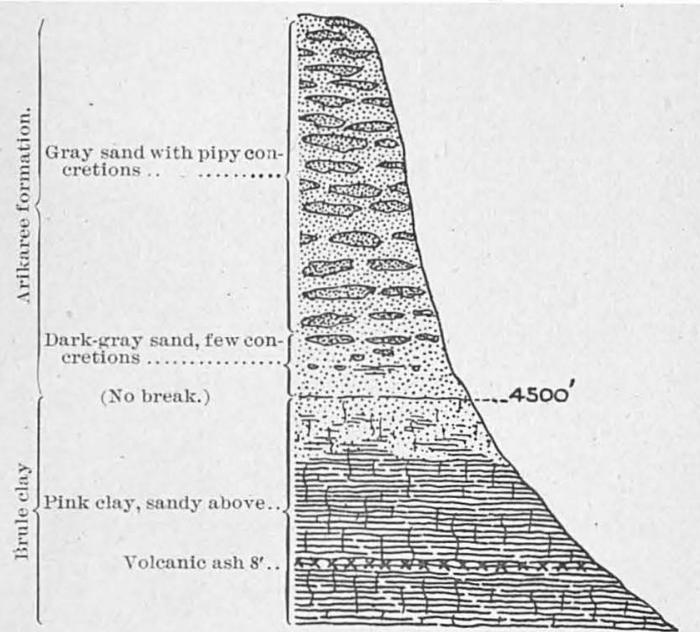

FIG. 2.-Section 6 miles west of Gering, Nebr., showing relations of Arikaree and Brule formations.

lands next south. The formation consists mainly of fine sand containing characteristic layers of hard, fine-grained, dark-gray concretions, often consisting of aggregations of long, irregular, cylindrical masses. These, for convenience, have been called "pipy concretions." They vary in thickness from a few inches to several feet, but from 10 to 15 inches is a fair average. Their trend is east-northeast and westnorthwest with surprising regularity. The layers are often many square yards in area. A typical exposure of the concretions is shown in Pl. XVIII, $B$. The sands vary from loose to fairly compact, and some are argillaceous. The colors are uniformly light gray. Owing to the presence of the hard concretions, the formation generally gives rise to ridges of considerable prominence. The steep escarpment of Pine Ridge consists almost entirely of Arikaree cliffs, of which typical views are given in PIs. VIII, XVII, and XXI. The relations of the Arikaree formation to associated deposits are particularly well exposed in the slopes adjoining the Platte and Pumpkinseed valleys. The formation lies on the Gering beds at many points, 
but in some areas appears to rest immediately. on the surface of the Brule clay. There is often no evidence of unconformity in either case. Usually there is an abrupt change in the character of the materials as the coarse beds of the Gering formation give place to fine massive Arikaree sands containing the pipy concretions. In some cases this concretionary development appears to have extended down into the Gering sediments, especially locally where these sediments are fine sands. This relation is illustrated in fig. 2 , and possibly also in fig. 14 , on page 35.

There is a possibility that the upper member of the Gering formation is a basal portion of the Arikaree formation, as suggested at some localities, which would often add difficulty to the identification of the Gering formation where it consisted of only one member. Along the north side of the Platte Valley, the south side of

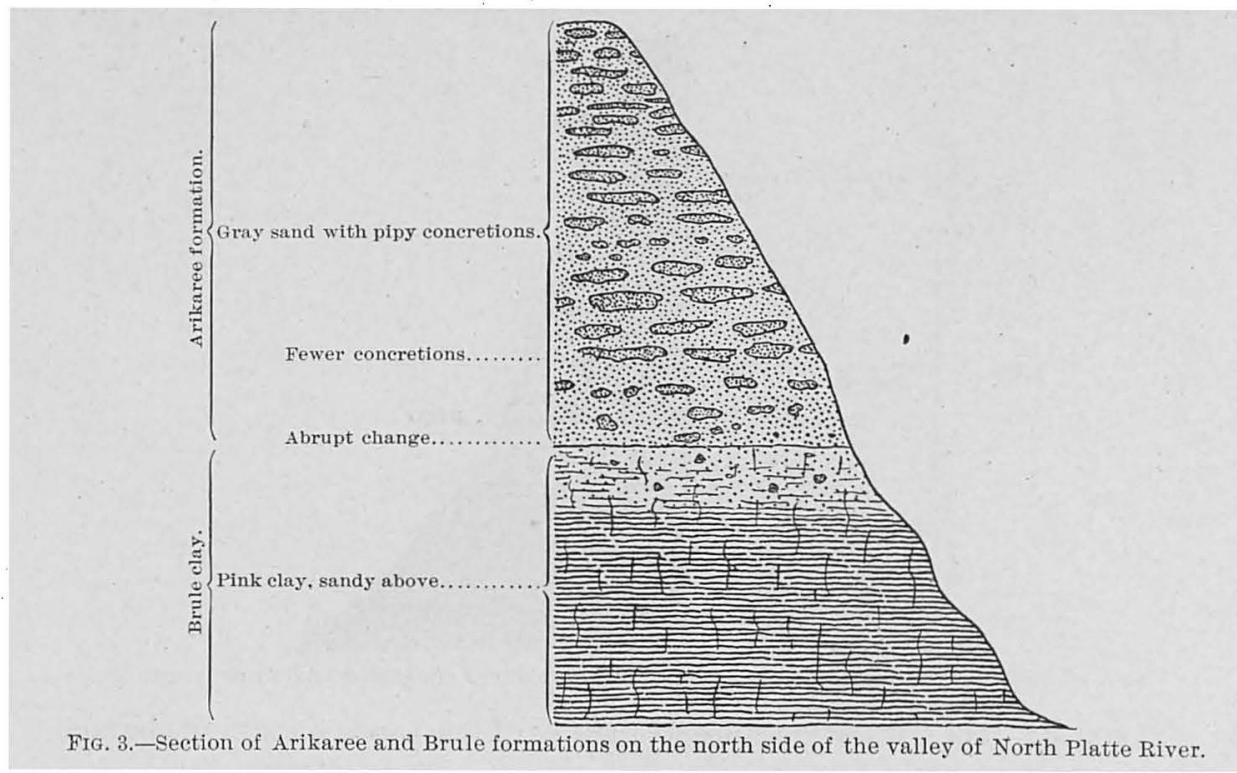

the Pumpkinseed Valley, and in portions of the ridge between these two valleys the Arikaree formation appears to lie directly on the Brule clay. In these instances there is often either only a faint suggestion of unconformity between the two formations when the exposures are carefully examined or simply a very rapid change from sandy, pinkish Brule clay, with some small siliceous concretions, to fine gray sands with the typical character and pipy concretions of the Arikaree formation. Fig. 3 shows the usual relations presented in the exposures along the north side of the Platte Valley.

In Pl. XVII, $B$, is shown an exposure in which there is marked unconformity between Arikaree and Brule deposits, and other exhibitions of similar relations are shown in sections $A$ and $C$ of $\mathrm{Pl}$. XV, sections $C$ and $D$ of Pl. XXVII, and Pls. XXVI and XXVIII. The relations of the Arikaree formation to the Ogalalla formation are described on page 24 . The two formations are sharply separated by 


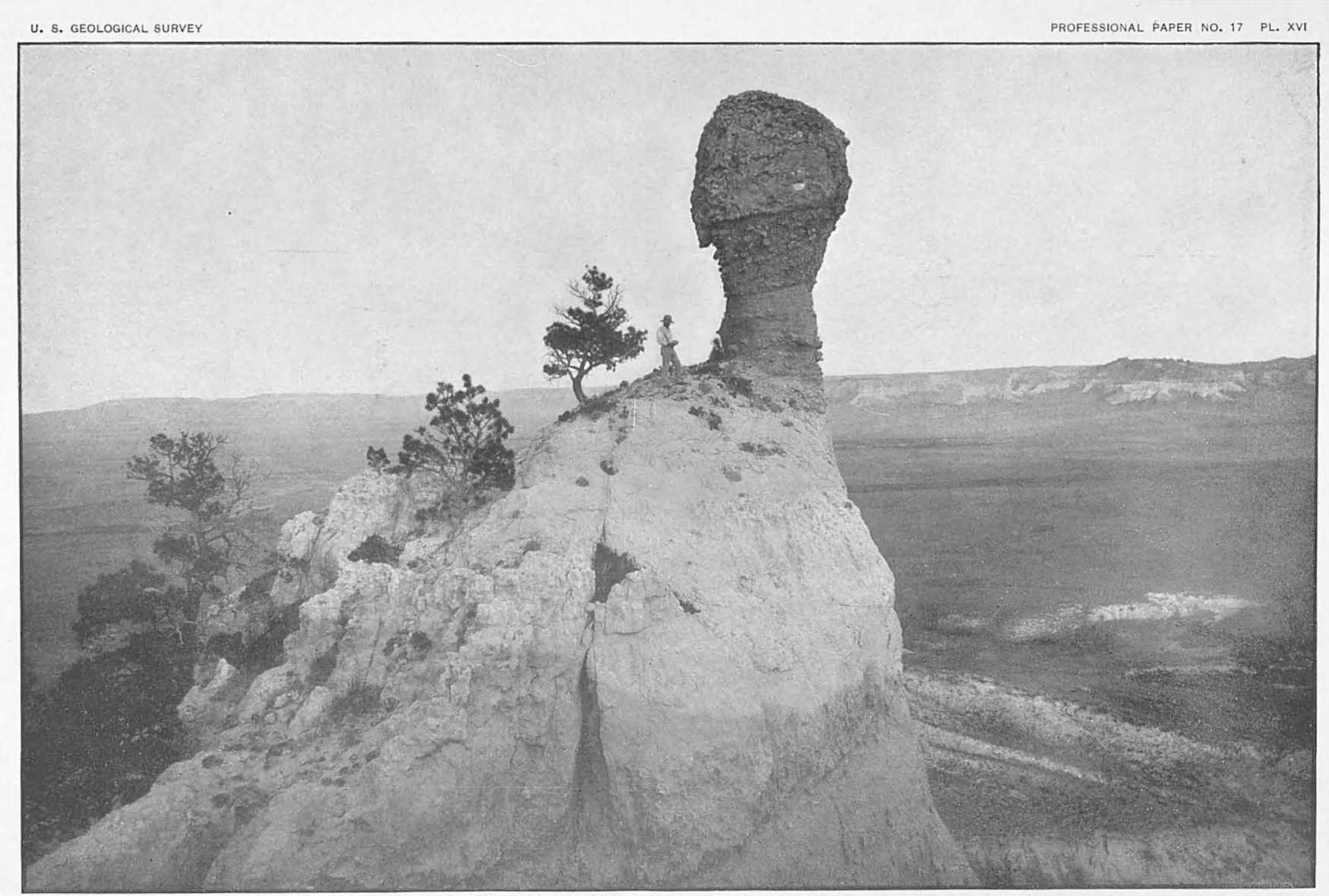

SMOKESTACK ROCK, LOOKING EAST; NEAR VIEW.

Conglomerate in Arikaree formation. 



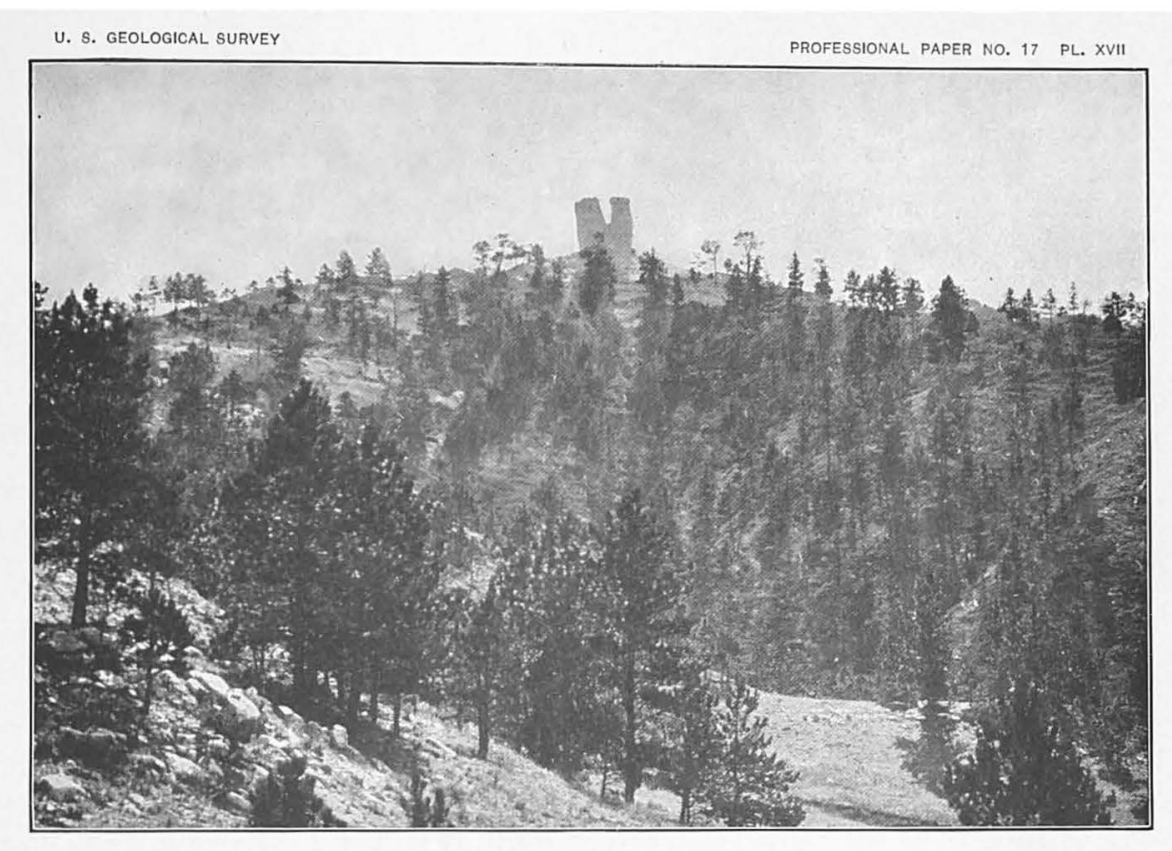

A. BUTte of ARIKAREe FORMATION, SOWBELLy CANYON, SIOUX COUNTY, NEBR.

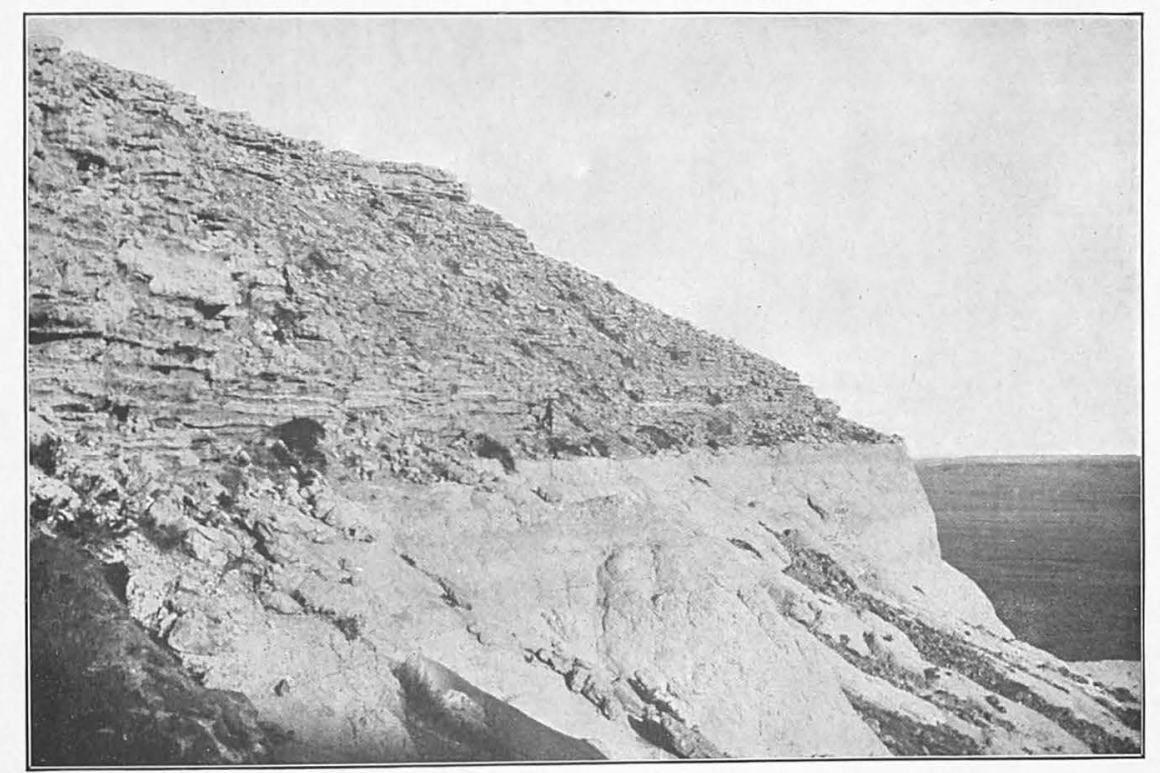

B. ARIKAREE FORMATION ON BRULE CLAY, SOUTHWEST PORTION OF SIOUX COUNTY, NEBR. 

an abrupt change in character of materials, and the basal Ogalalla beds are mainly conglomeratic. The thinning out of the Arikaree deposits to the southeast is clearly illustrated in many exposures south of Redington. All along the northern edge of the table-land in Banner County the formation has less thickness than it presents in the ridge north, where, in the vicinity of Wildcat Mountain, it is nearly 500 feet thick. Southwest of Harrisburg the amount is about 150 feet; south of Freeport it is 100 feet, as shown in Pl. XV, $A$; in Hackberry Canyon it is 40 feet; and at Langs Point Arikaree beds are absent, the Ogalalla conglomerate here lying. directly on the Brule clay, as shown in section $B$ of Pl. XV. Southeast of Langs Point there are a few thin outlying lenses of Arikaree beds, one of which is shown in section $C$ of $\mathrm{Pl} . \mathrm{XV}$, but thence to the east it thins out and the typical relations presented are those shown in section $D$ of Pl. XV. In the upper portion of the valley of Lawrence Fork there is an outlying area of the formation, only a few feet thick, between supposed Gering and Ogalalla formations, as shown in fig. 8 (p. 31).
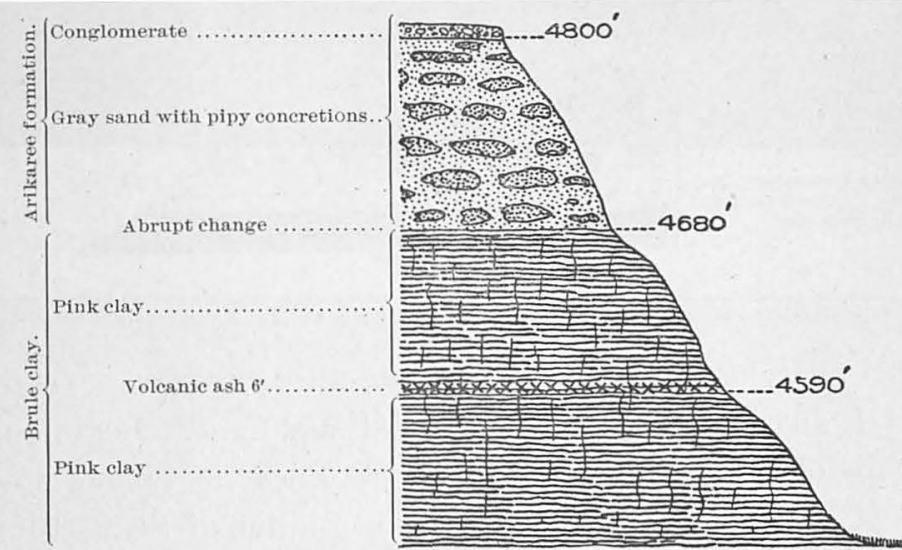

FIG. 4.-Section 3 miles northwest of Dorringten, Nebr., showing the relations of conglomerate in Arikaree formation.

Dæmonelix in various forms occurs extensirely in this formation, and in Pine Ridge, in Sioux County, the large forms of the "Deril's corkscrew" are found in very great abundance in the upper beds of the formation. Prof. E. H. Barbour has described these forms in detail and given an account of their mode of occurrence. ${ }^{a}$ The larger forms are most abundant in the upper portions of the depressions north of Harrison, but they were observed also as far east as Andrews, for some distance in the valley of Niobrara River above Royville, and as far west as Lusk, in Wyoming. The smaller forms are very generally present throughout the region, and they also occur in the Ogalalla formation. In Pl. XIX is shown an exposure of typical Dæmonelix beds containing the large corkscrew forms. It is believed that no one observing these fossils in the field would have any doubt as to their vegetal nature. 
In a portion of its area the Arikaree formation has been observed to contain a series of old channels filled with coarse conglomerate. The occurrence of this conglomerate is apparently restricted to the ridge lying next south of North Platte River and to the vicinity of Spoon Butte, near the head of Sheep Creek, in Sioux County. The horizon is somewhat above the base of the formation, and the conglomerate is distinct from some local beds of coarse deposits occasionally noticed at or near the base of the formation.

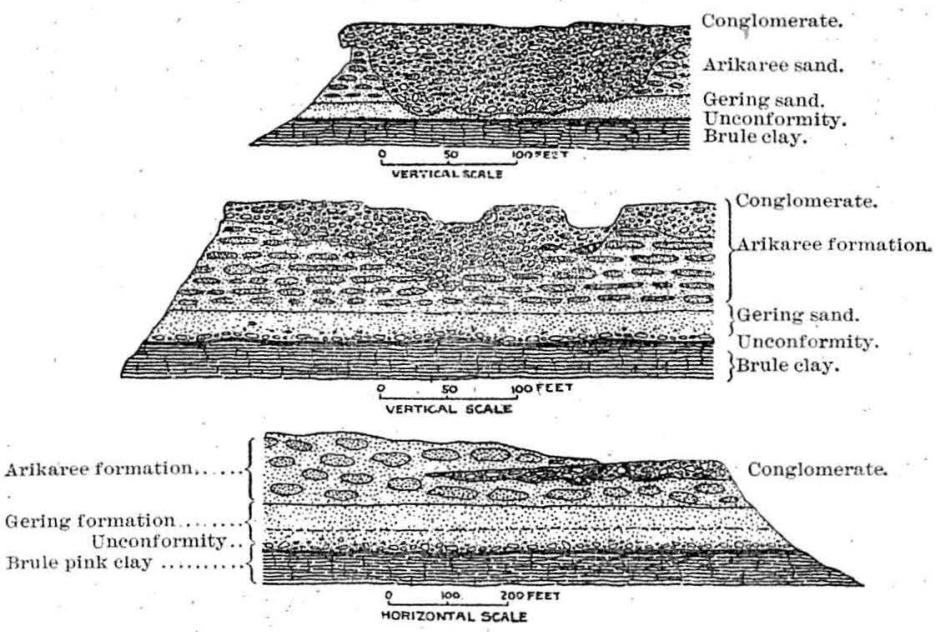

F1G. 5.-Sections 8 miles south-southeast of Gering, Nebr, showing relations of conglomerate in Arikaree formations.

Some of the relations of these conglomerate-filled channels are shown in section $F$ of Pl. XXVIII, and in. Pls. VI, XIV, and XVI, and fig. 5. Beginning at the east, the first outcrops observed were in Smokestack Rock, in Banner County. They were next seen at intervals westward along the south line of Scotts Bluff County, in buttes and high points, as far west as the meridian of Gering, and detached areas are

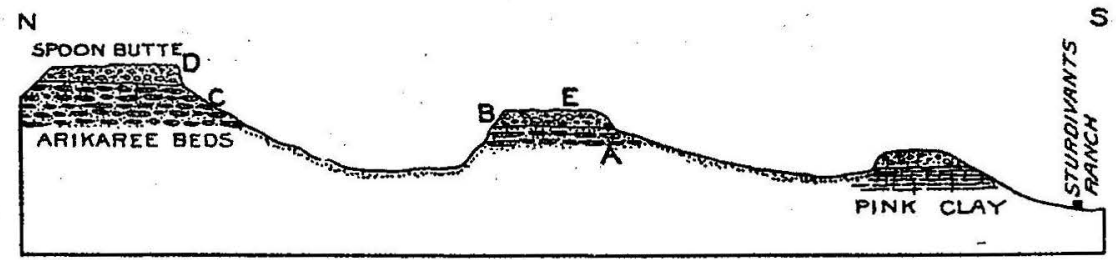

Fra. 6.-Cross section from the eastern end of Spoon Butte sonthward to Sturdivant ranch, looking east.

exposed on the north side of the ridge southwest of Gering. The last outcrop occurs at a point 3 miles north-northwest of Dorrington, near the western end of the ridge, where it has the relations shown in fig. 4.

It is probable that the channel is continuous under the ridge between these points. Some features of the more prominent exposures are shown in Pls. XIV and XVI. The material is a conglomerate of pebbles and bowlders of gray sand- 


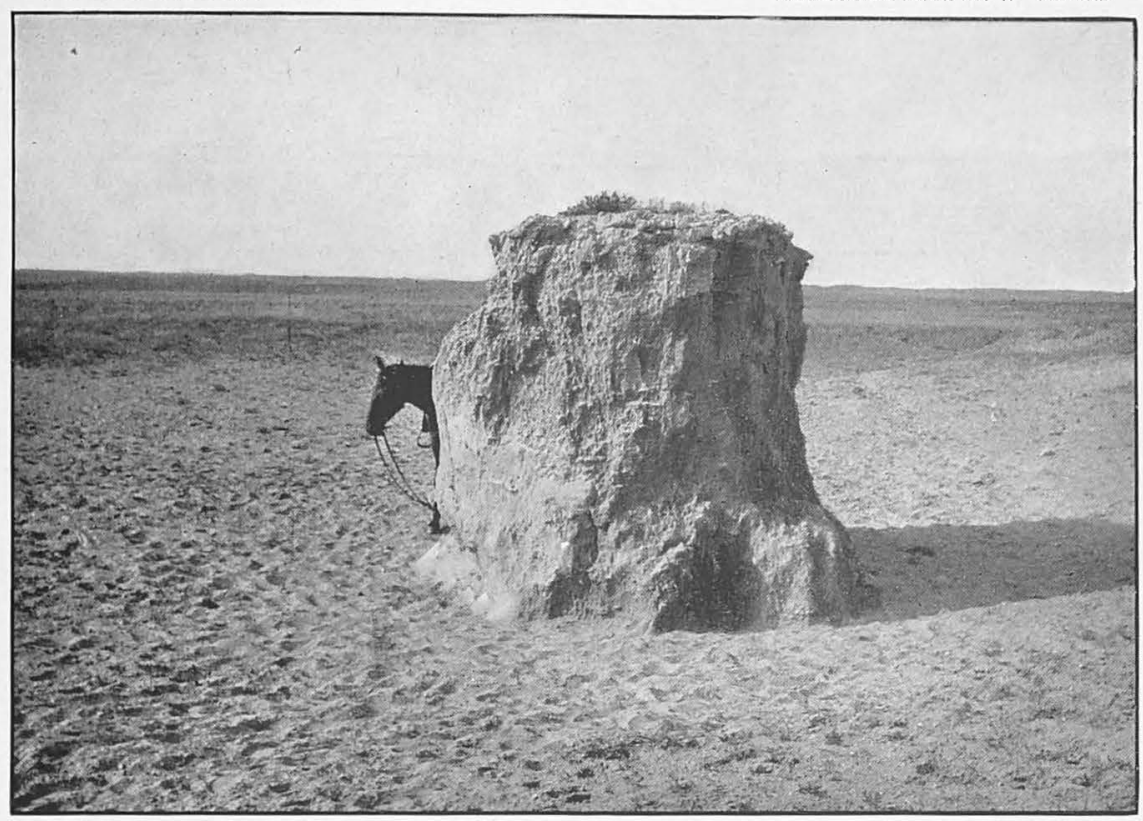

A. BLOWOUT WITH CORE, ARIKAREE FORMATION, SIOUX COUNTY, NEBR.

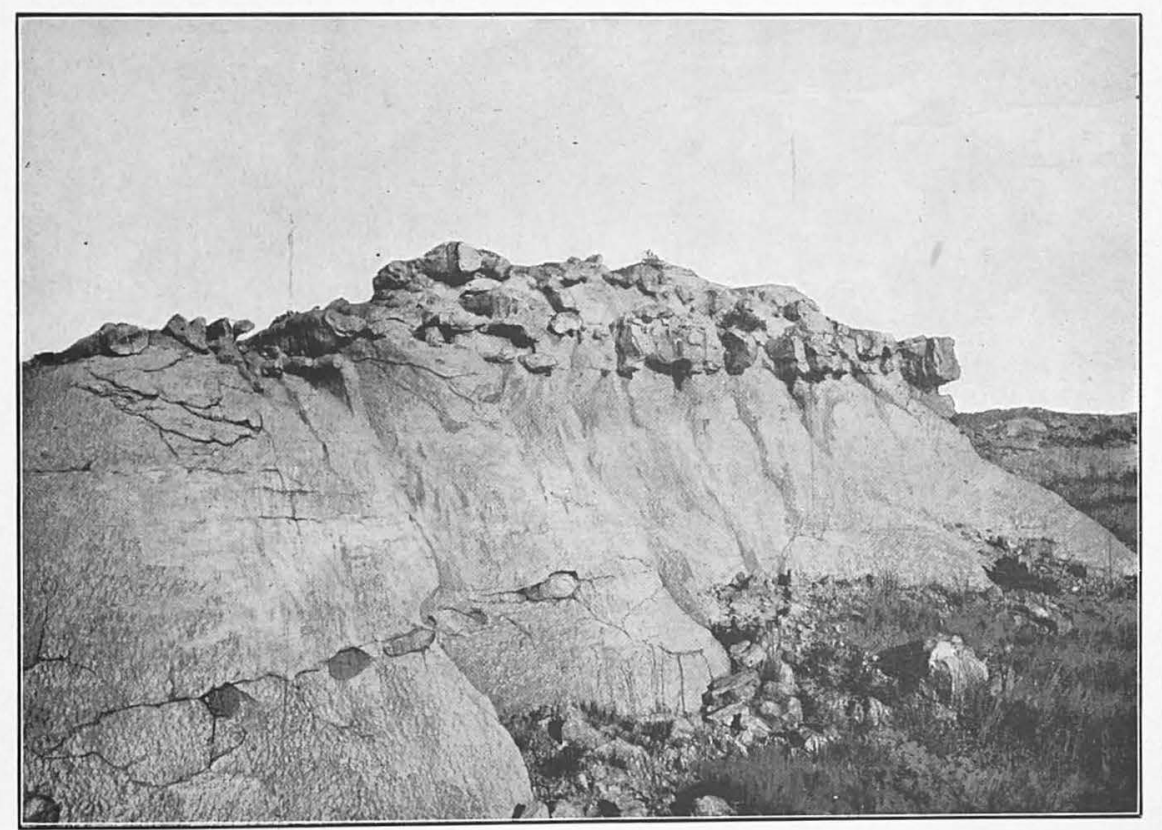

B. PIPY CONCRETIONS, ARIKAREE FORMATION, SCOTTS BLUFF COUNTY, NEBR. 



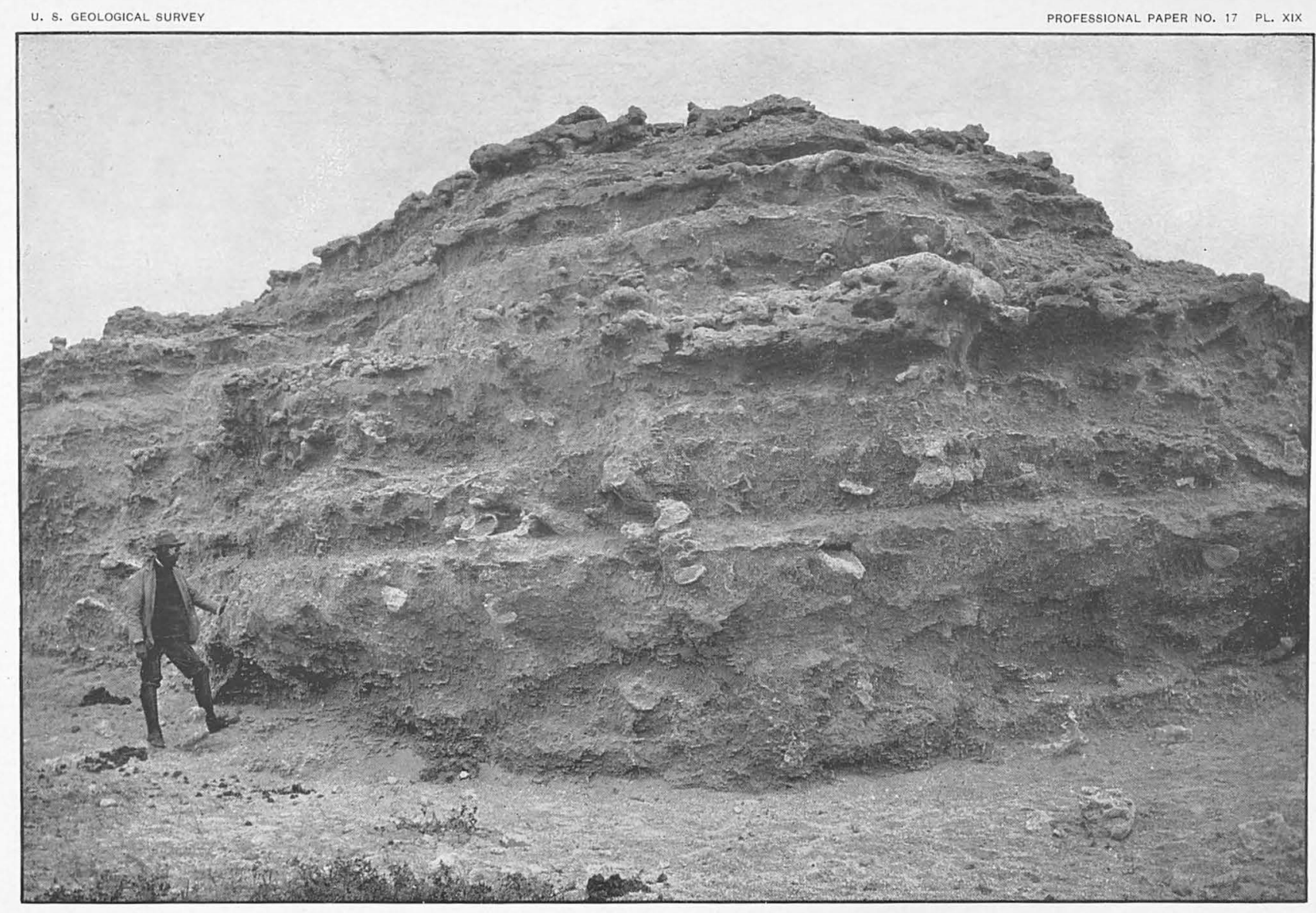

DEEMONELIX BEDS. IN ARIKAREE FORMATION AT HEAD OF LITTLE MONROE CANYON, SIOUX COUNTY, NEBR. 

stone, generally firmly cemented by siliceous matrix. The greatest thickness observed was 30 feet, in the high point 3 miles south of Larissa. Smokestack Rock exposes about 25 feet. At many localities it may be seen that the beds lie on typical Arikaree deposits, as shown in Pl. XIV, $B$, and they are overlain by typical beds of the same formation. This relation is shown in fig. 5 (p. 28) and fig. 12 (p. 34).

In the Spoon Butte and adjoining ridges the conglomerates are of somewhat different character, consisting in large part of crystalline rocks and apparently lying on a steeply sloping surface. The relations are shown in fig. 6 .

In this vicinity it was not practicable to ascertain the relations to overlying beds.

The Arikaree deposits contain a large amount of volcanic ash, mainly as a constituent intermixed with the sand, but there are also several distinct beds of ash at one or two horizons, though only of local occurrence. The relations of these beds are indicated in section $A$ of Pl. XXVIII and figs. 1, 7, 10, 12, and 18, and some further information regarding them will be found on page 42 .

Molluscan fresh-water fossils of several species have been found in this formation, but they are not sufficiently distinctive to indicate its age precisely. One abundantly fossiliferous locality was discovered south of Gering, where the matrix was a thin bed of diatomaceous earth. Vertebrate remains were collected in small numbers.

GERING FORMATION.

Underlying the Arikaree formation, in a portion of the area, there is a series of coarse sands, often containing pebbles, which appears to be an entirely distinct formation. It is not separated by unconformity, but it has distinctive characters over an area of considerable extent. In its typical exposures it is separated from the Brule clays by a clearly marked unconformity, some of the features of which are shown in PI. XXV. Its thickness varies from a thin wedge to over 200 feet. Its relations are extensively exhibited in the ridge lying next south of North Platte River, and it is thick and apparently continuous along the northern face of Pine Ridge. The southernmost exposures are some doubtful ones on Lawrence Fork, near its head. In Pls. XXVI, XXVII, and XXVIII, and figs. 7 to 17, the stratigraphic relations of this formation are illustrated. Its greatest development in the Platte Valley is south-southwest of Gering, where 200 feet are exposed, and about Chimney Rock, where a thickness of about 145 feet is attained. It is over 100 feet thick in Courthouse Rock and in the vicinity of Birdcage Gap and Redington Gap. To the west and south it thins out, and at some points along both sides of the ridge it is apparently absent, or possibly where it appears to be absent it is represented either by clayey members which are not distinguishable from the Brule clay or by fine sand with concretions resembling Ogalalla beds. Its absence is almost certain in the ridge about Wildcat Mountain. In Scotts Bluff the relations of the formation are 
very distinct and 60 feet are exposed. On the slopes north of Platte River the formation appears to be absent except in a small area near the southwest corner of Sioux County, where the features shown in fig. 7 indicate that the formation is probably present locally.

Along the north face of Pine Ridge the formation presents the features shown in figs. 19 and 20 (pp. 39 and 40 ) and Pl. XX.

Some further facts and inferences as to its relations are shown in cross sections in PI. XII. No definite evidence of the continuance of the formation could be found in the slopes south of Pumpkinseed Creek except in the valley of Lawrence Fork, in sec. $4, T: 16$, R. 54 , where there is an exhibition of the features shown in fig. 8 .

In the Lodgepole Valley the Arikaree formation appears to lie directly on the Brule clay, both the Gering and Ogalalla formations being absent.

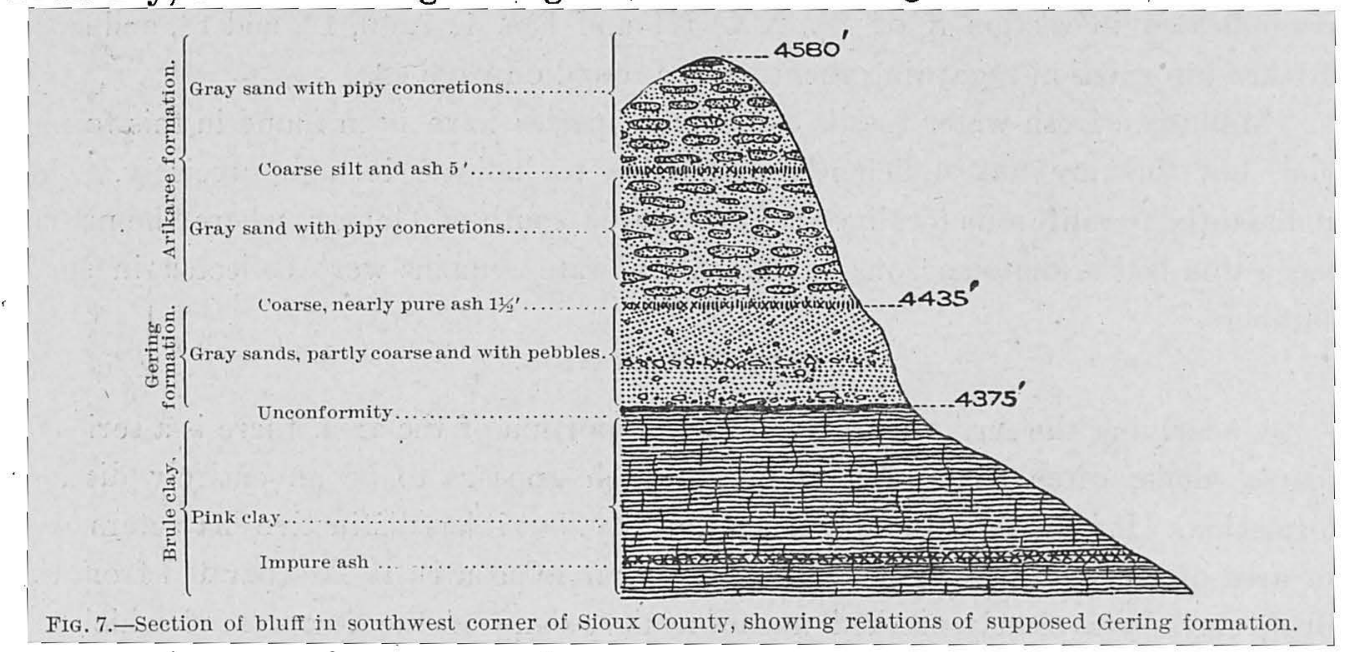

The Gering formation presents many local features of stratigraphy, particularly in the ridge between the valleys of Platte River and Pumpkinseed Creek. Beginning at Jail Rock, there are instructive exposures at frequent intervals to the western end of the ridge. At Courthouse Rock there are presented the relations shown in section $A$ of PI. XXVI. At an altitude of 3,940 feet the distinctive Brule clay is unconformably overlain by the Gering formation, apparently comprising two members, separated by marked unconformity by erosion. In both members there are coarse beds below containing local conglomerate, merging upward into sand, and finally into sandy clay. The total thickness is 110 feet. The characteristic Arikaree formation capping Courthouse Rock begins abruptly, but with no sign of unconformity. Jail Rock, as shown in Pl. V; is capped by the Gering formation. The two members of this formation present about the same relations at Birdcage Gap as shown in section $B$ of Pl. XXVI, but they have somewhat greater thickness. In the pinkish sandy clay, at an altitude of 4,080 feet, there was found a portion of the 


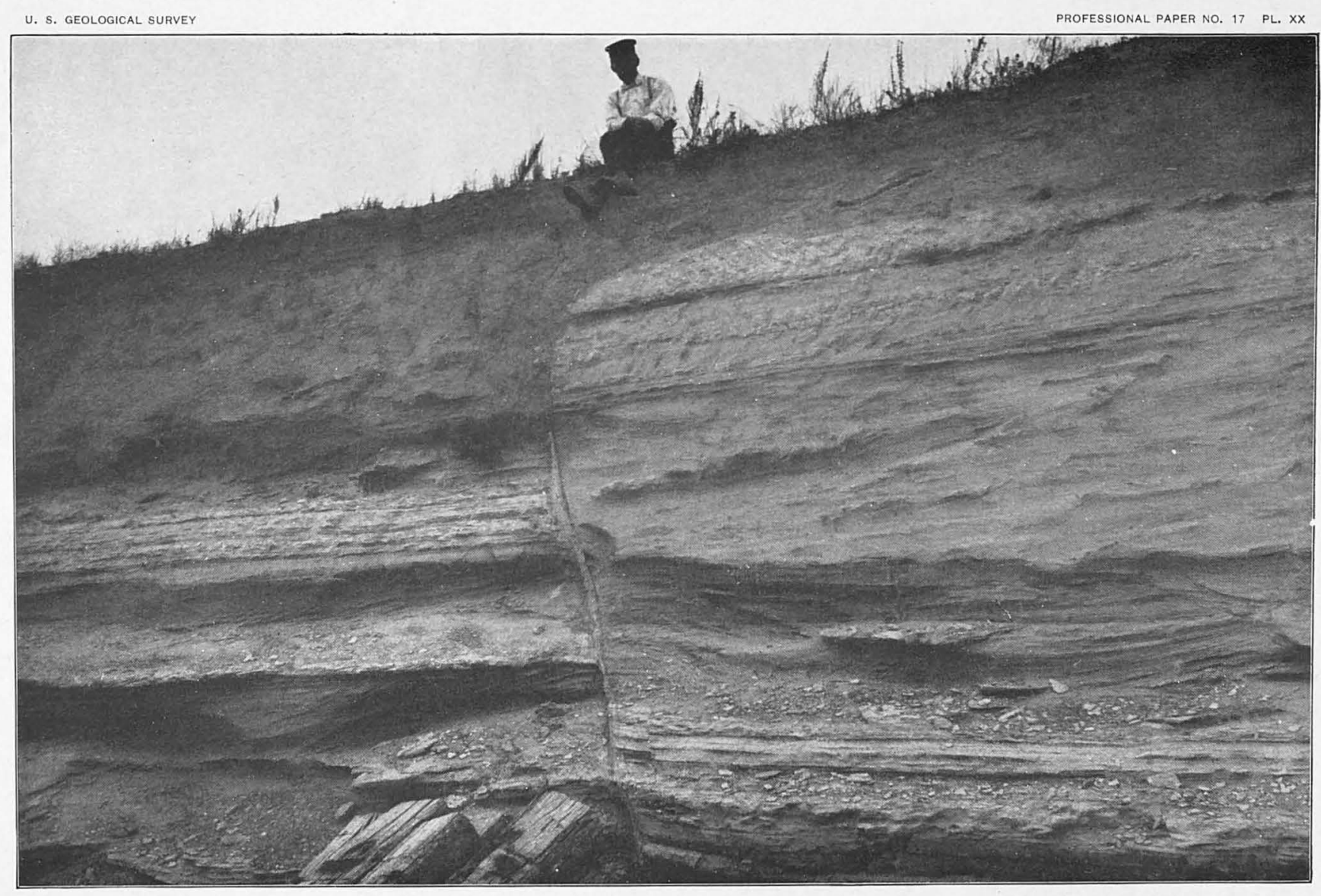

GERING FORMATION WITH FAULT, NEAR RUTLAND, DAWES COUNTY, NEBR. 



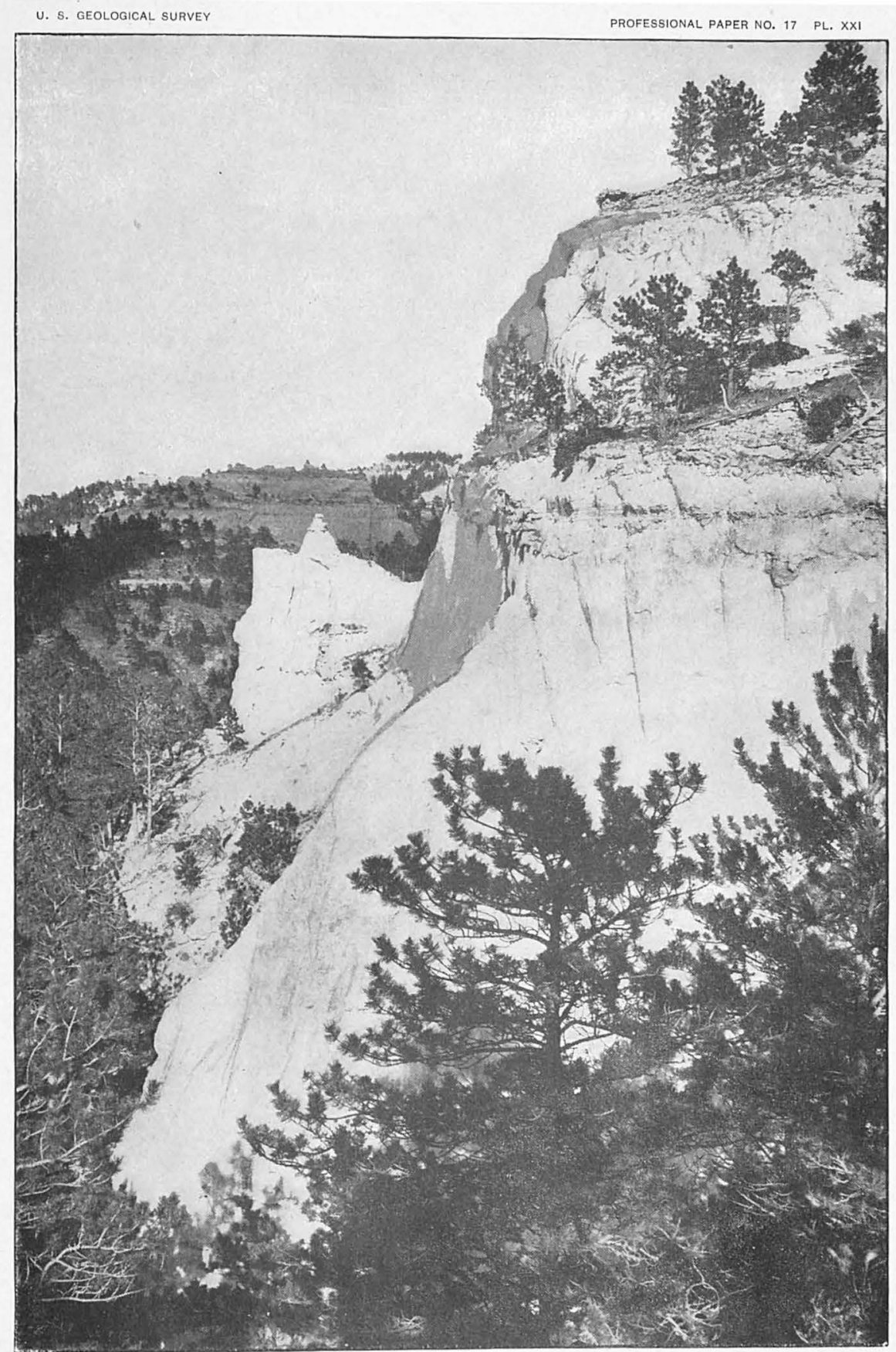

CLIFFS OF ARIKAREE FORMATION, NORTH FACE OF PINE RIDGE, NEAR MONROE CANYON, SIOUX COUNTY, NEBR

(From photugraph by E. H. Barbour, University of Nebraska.) 

skeleton of a new species of Dinictis. ${ }^{a}$ A view of the relations in Birdcage Gap is given in Pl. XXII.

At Redington Gap the upper member of the Gering formation is not distinguishable, and the total thickness is less. A local bed of volcanic ash 5 feet thick appears to mark the top of the formation. The principal features are shown in section $C$ of PI. XXVI. Three miles northwest of Redington Gap there was found the section shown in PI. XXVI, $D$. The Gering formation here presents the usual basal beds of coarse material lying unconformably on the Brule clay. The change to the Arikaree formation above is abrupt, but not marked by unconformity.

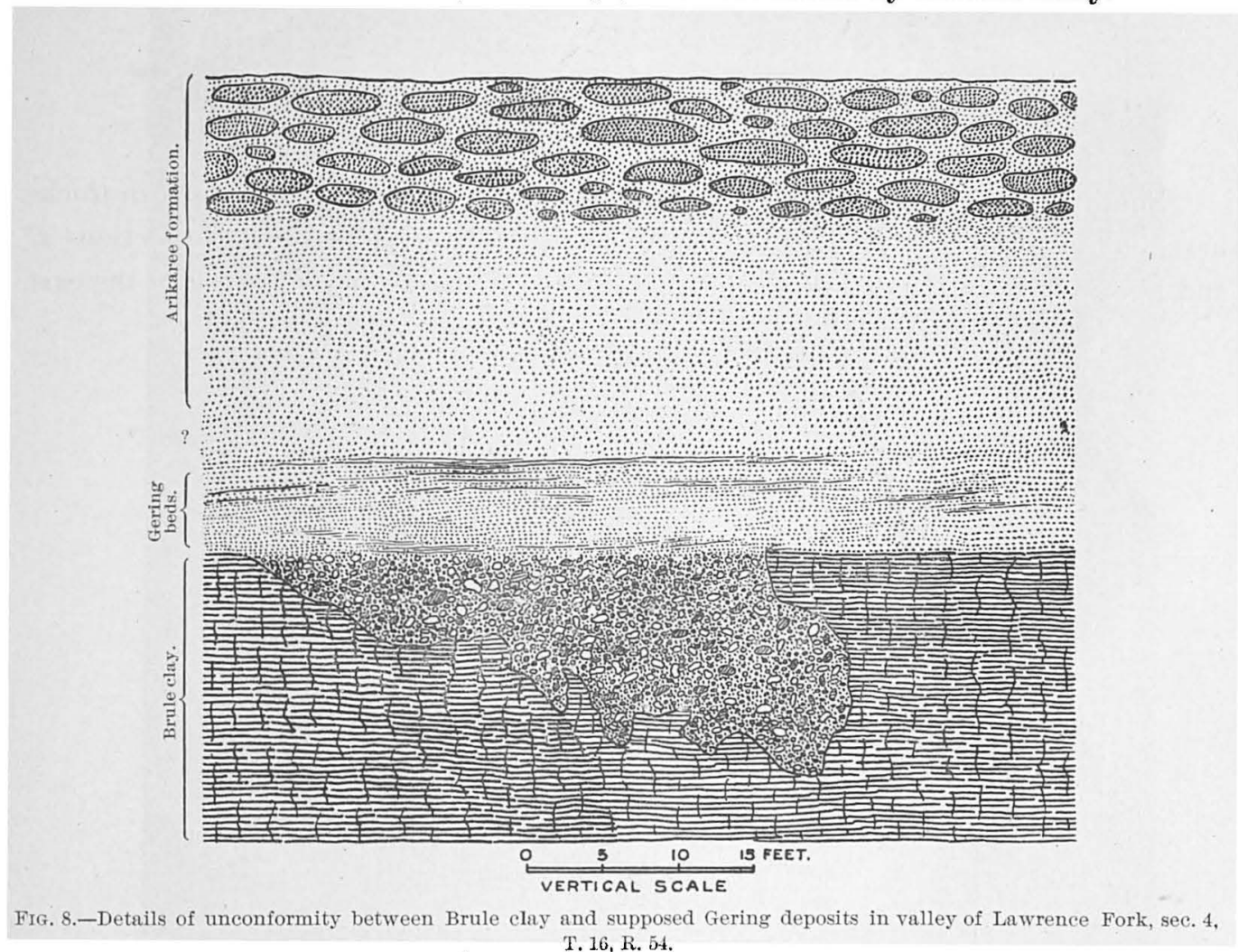

Approaching Chimney Rock there are presented the features shown in sections $E$ and $F$ of Pl. XXVI. The thickness of the Gering formation here averages about 125 feet, and there is much local rariation in the stratigraphy. Coarse basal beds are often exposed lying unconformably on the Brule clay. A thin local bed of volcanic ash is conspicuous in some exposures. Chimney Rock consists of a spire of Gering formation rising from a conical hill of Brule clay. The material is a gray, thin-bedded, soft sandstone with slightly coarser materials at its base. The 
unconformable contact with the Brule clay is at an altitude of 4,100 feet, and there is here considerable carbonaceous material, strongly suggestive of an old soil. At an altitude of 4,135 feet there is a faint unconformity, just above which there are two thin beds containing volcanic ash. Two views of Chimney Rock are given in Pl. XXIV, and the relations of the formations are shown in section $A$ of Pl. XXVII.

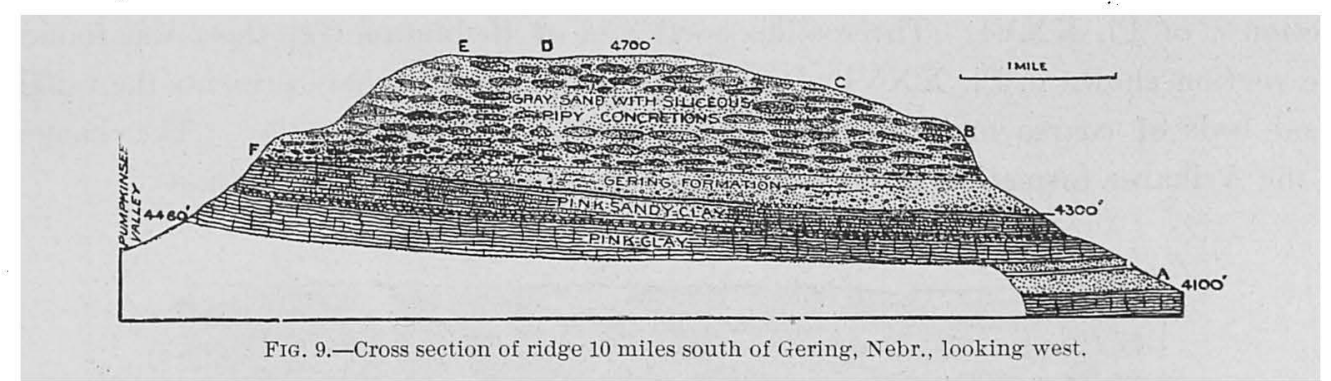

Southwest of Chimney Rock the Gering formation greatly decreases in thickness, but it continues to present its characteristic features, as shown in sections $B$ and $C$ of Pl. XXVII. The two members are well characterized as far as the east

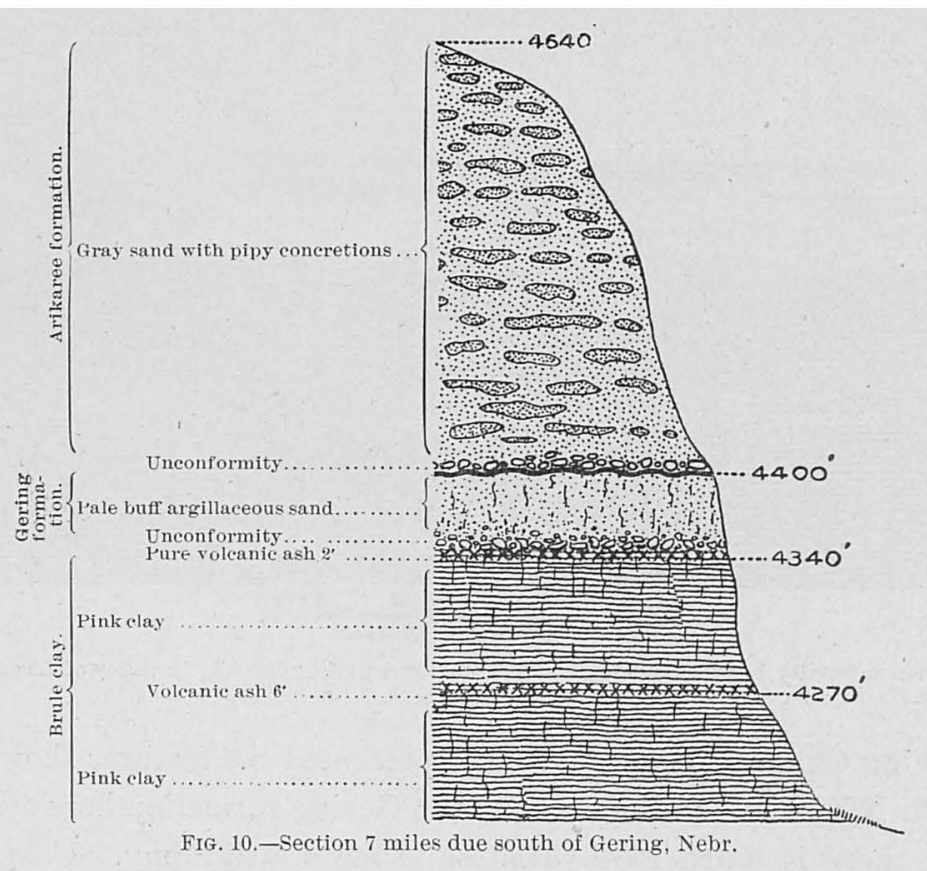

side of Sheep Mountain. Along the south side of this butte the basal member of the Gering formation is, in places, not clearly separable.

At the curiously sculptured Twin Sisters, which are of Gering formation, the unconformity is finely exhibited, as shown in Pl. VII, $A$. The materials consist of coarse sands and soft sandstone, merging upward into a 6 -foot bed of pinkish sandy 


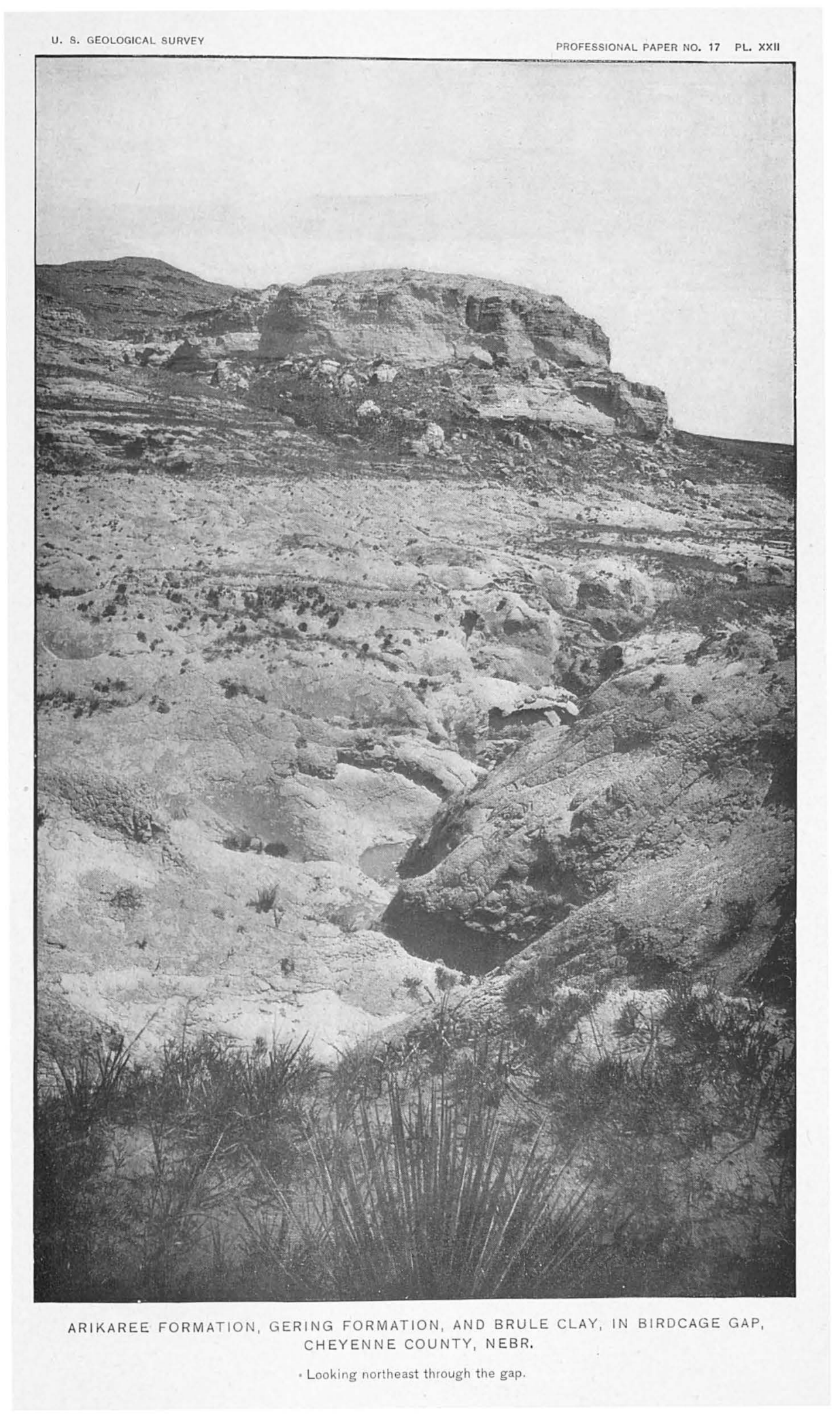





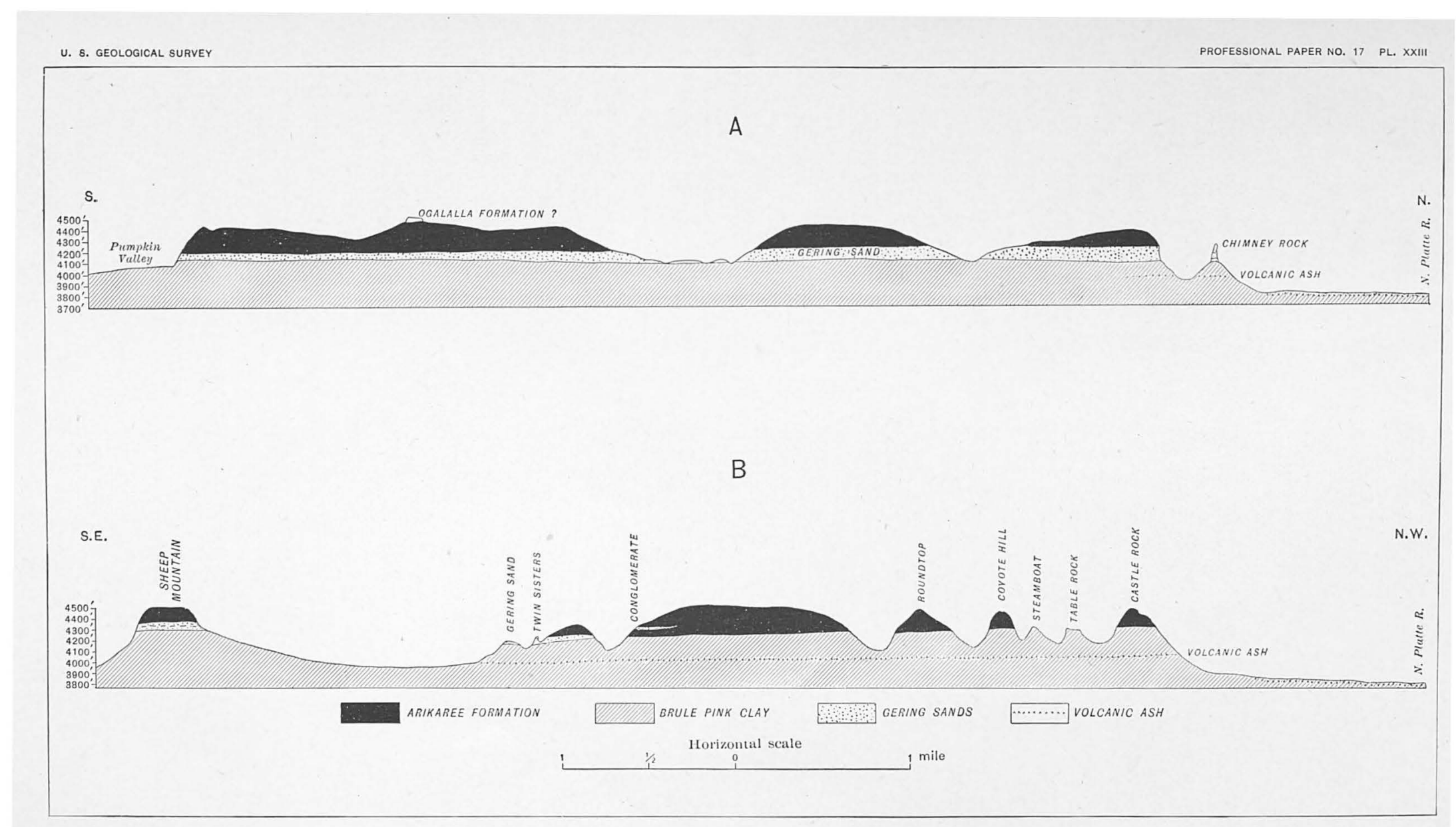

CROSS SECTIONS, SHOWING RELATIONS OF FORMATIONS NEAR CHIMNEY ROCK AND HORSESHOE FLAT, NEBR.

$A$, Near Chimney Rock; $B$, near Horseshoe Flat. 

GEOLOGY WEST OF ONE HUNDRED AND THIRD MERIDIAN.

clay, above which there is a moderately sharp break, followed by an upper member of gray sand which constitutes the heads and shoulders of the "Sisters." Some of the relations in this vicinity are shown in section $B$ of PI. XXIII, which also shows the apparent thinning out of the formation a short distance northward.

The Gering formation appears to be absent at the Smokestack and in Round Top, Coyote Hill, and Castle Rock. In Castle Rock, as shown in section $D$ of Pl. XXVII, the Brule clays become sandy in their upper portion, but present no suggestion of stratigraphic break until the base of the well-characterized Arikaree deposits is reached, at an altitude of 4,340 feet, where there is an unconformity

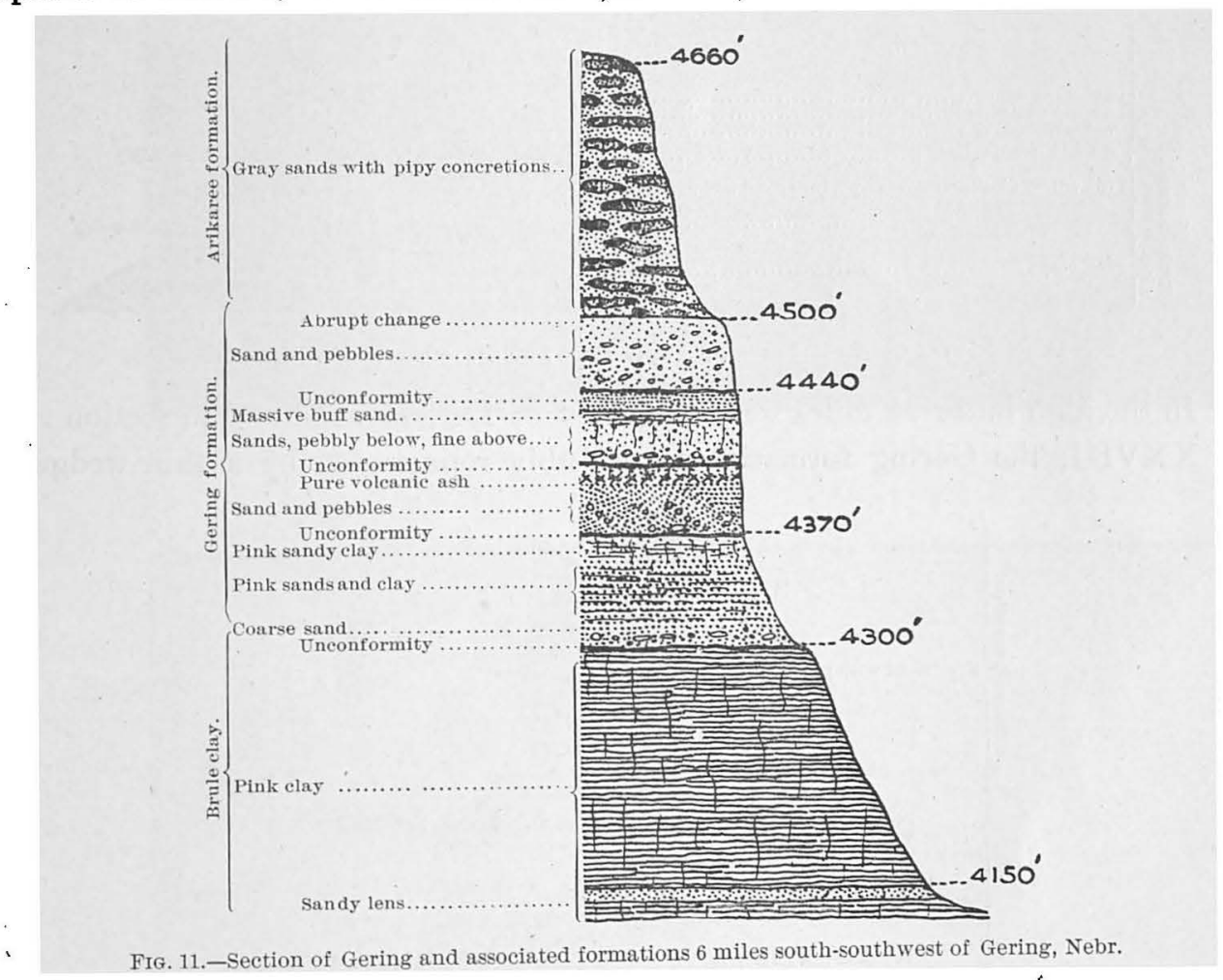

marked by a bed of white clay a foot thick on a carbonaceous surface strongly suggestive of old soil. This soil and the relations of the formation indicate that there was here a land surface while the Gering formation was being deposited to the south.

The Gering formation extends continuously for several miles west from the Twin Sisters. At a point 4 miles west-northwest it has the relations shown in section $F$ of Pl. XXVIII, consisting of two members with an aggregate thickness of 120 feet. It contains the usual coarse beds at the base of each member, and in the base of the lower member there is a $2 \frac{1}{2}$-foot bed of pure volcanic ash. In the next bluff, $1 \frac{1}{2}$ miles northwest, there are exposed the features shown in section $C$ of Pl. XXVIII.

14478-No. $17-03-3$ 
In the next $1 \frac{1}{2}$ miles the formation thins rapidly, as shown in section $B$ of $\mathrm{Pl}$. XXVIII, and it appears to thin out locally to the south and at intervals to the west.

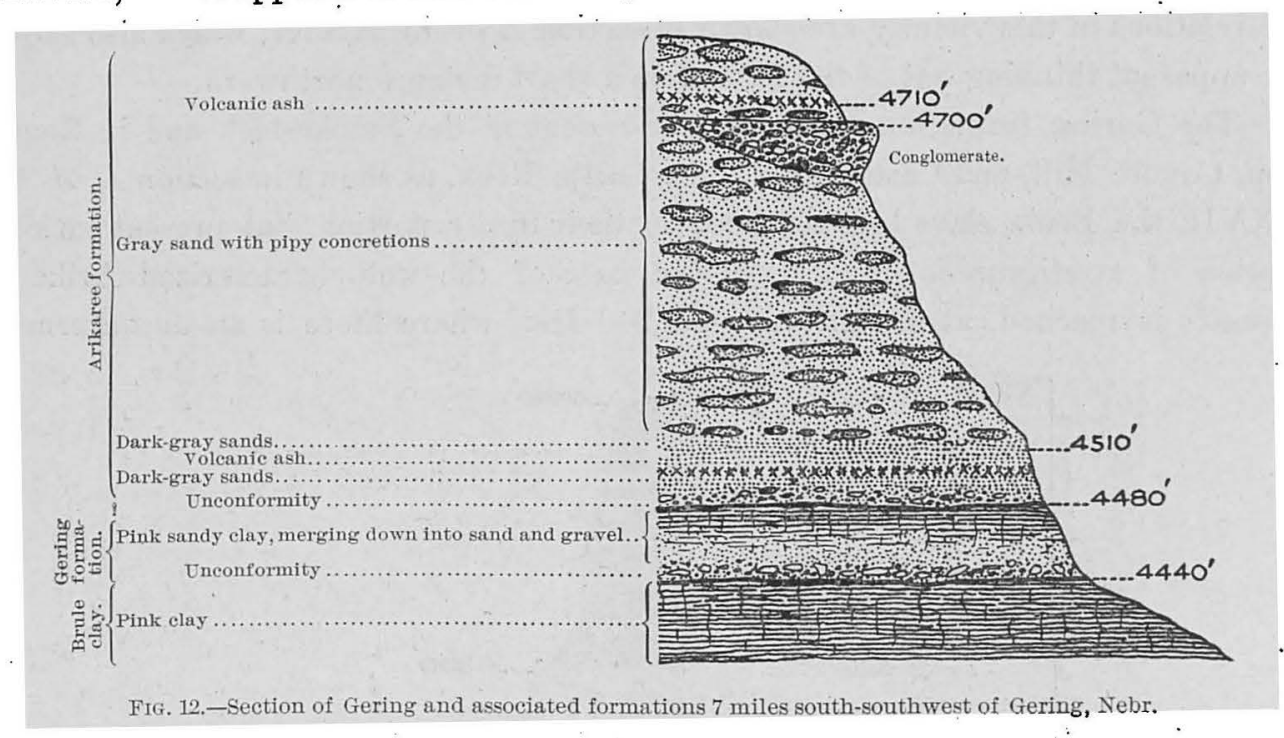

In the high butte $2 \frac{1}{2}$ miles west-southwest of Larissa, as shown in section $A$ of Pl. XXVLI, the Gering formation is probably represented by a thin wedge of

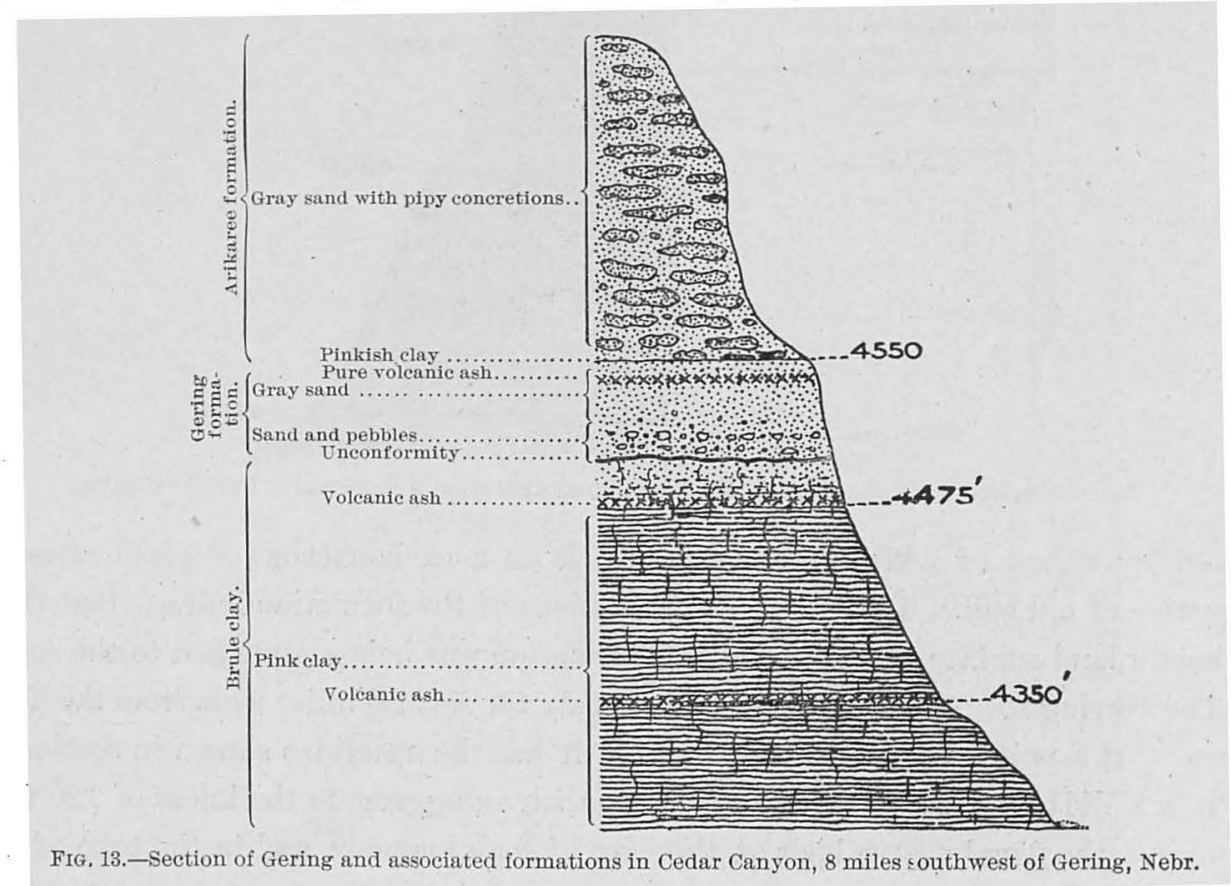

laminated sandstone, which is exposed on the south slope, but is absent to the north. In the buttes south of Gering the formation occurs in irregular masses, and for some 


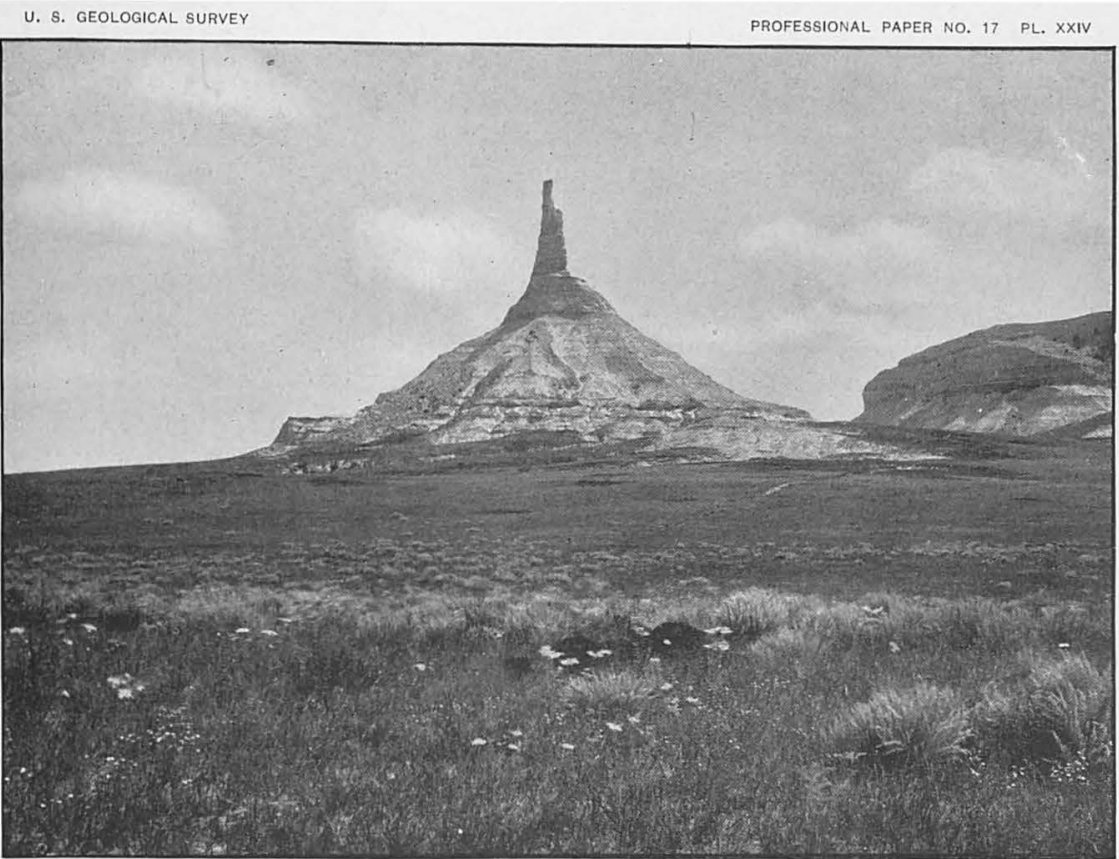

A.

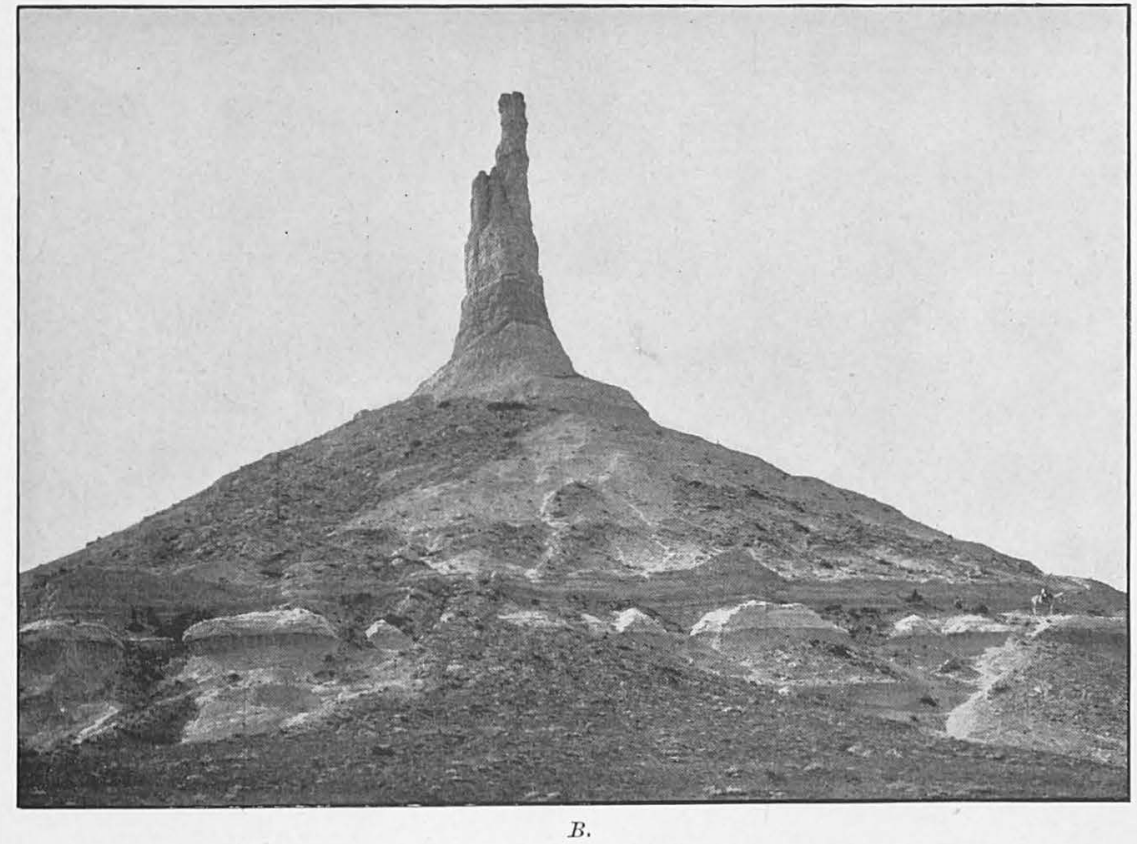

CHIMNEY ROCK, CHEYENNE COUNTY, NEBR $A$, From the west, showing volcanic-ash bed; $B$, from the east, Gering sandstone on Brule clay (the horse is on
a bed of volcanic ash). 


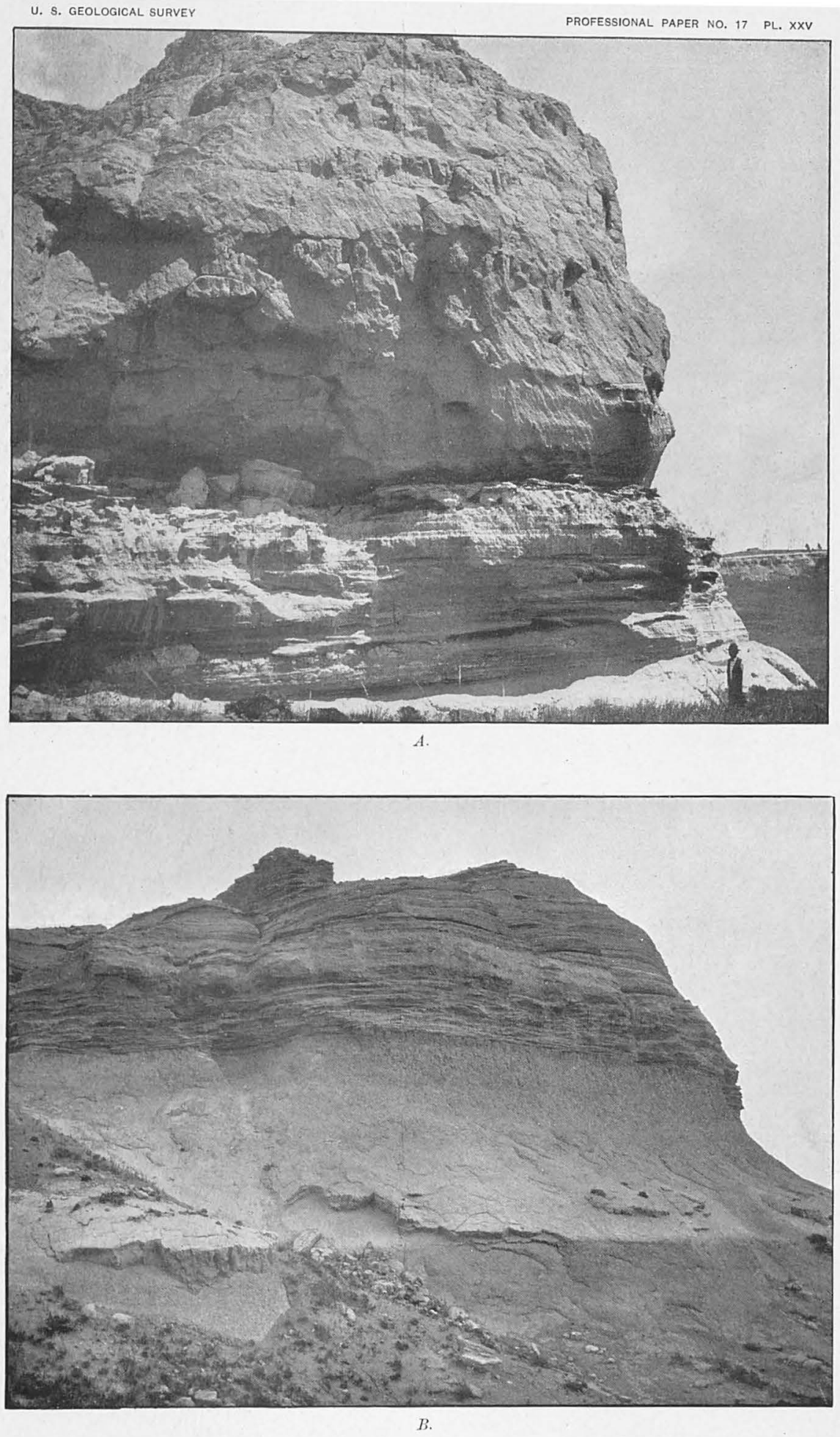

GERING FORMATION, LYING UNCONFORMABLY ON BRULE CLAY, CHEYENNE COUNTY, NEBR.

$A$, With conglomeratic beds, 4 miles northwest of Redington (the man's hand is at the contact); $B, 2$ miles
southwest of Chimney Rock. 

distance is not over 50 feet in thickness. Its relations in this vicinity are shown in fig. 9, at B and C. At $B$ in this section the Gering beds consist of sand and sandy clay, with streaks of conglomerate at their base. There is a very abrupt.change to Arikaree beds at their summit. The details of stratigraphy at $B$ are shown in fig. 10 .

At this exposure there is a bed of rolcanic ash in the base of the Gering formation, with alternations of sands and sandy clays above to a sharp unconformity at 4,390 feet. Above this unconformity are sands, pebbly at base, which appear to merge up into the Arikaree beds. They may, however, constitute the upper member of the Gering formation.

In the very prominent point in the northwest corner of T. 20 , R. 55,6 miles . south-southwest of Gering, the formation attains its maximum development for this district, having a thickness of 200 feet and the composition shown in fig. 11.

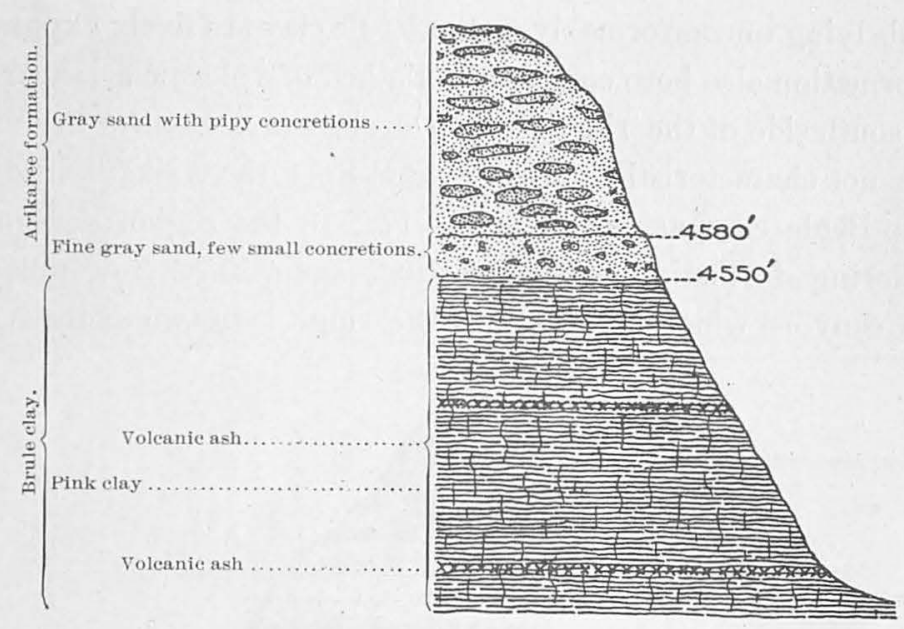

FIG. 14.-Section of Gering and associated formations at the mouth of Cedar Canyon, 7 miles southwest of Gering. Nebr.

A mile south of this exposure the Gering beds have the character and relations shown in fig. 12, which illustrates the thinning to the south.

The unconformity at $t, 480$ feet. may be either in the Gering formation, separating it into two members, or at the base of the Arikaree formation, here including coarse beds and a thin layer of nearly pure volcanic ash. West of this vicinity the formation again thins rapidly, and on the north side of the upper part of Cedar Canyon it has the relations shown in fig. 13.

One mile northeast of this exposure, in the high point at the mouth of Cedar Canyon, the formation is only doubtfully recognized, with the relations shown in fig. 14. In other places to the west and north for some distance the formation is either absent or very thin and not well characterized.

In the Scotts Bluff ridge west of Gering the Gering formation has a thickness 
of 60 feet. It is finely exposed in the butte of which. Scotts Bliff is the north face, where its relations are as shown in fig. 18. Some of its features may also be seen in Pl. XXIX. Dome Rock exhibits 50 feet of the Gering formation, capped by a small mass of Arikaree formation. In the vicinity of Signal Butte the Gering formation appears to be represented by 60 feet of laminated dark-gray sands or soft sandstone lying unconformably on the Brule clay, the unconformity being

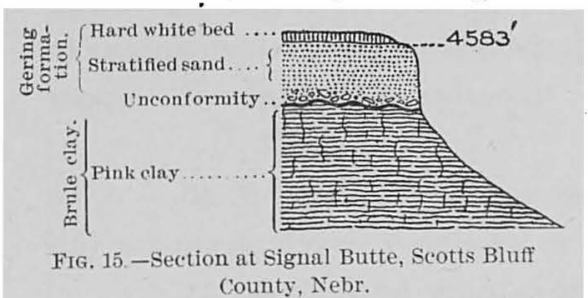
strongly marked. At the top of the butte there is a cap of thin, hard, white calcareous deposit, which extends widely in the vicinity. The relations are shown in fig. 15 .

The Gering formation is developed in places north of Dorrington with the relations shown in fig. 16. The thickness is 50 feet, and the coarse basal beds lying uncomformably on the Brule clay are finely exposed at several points. The formation also here contains a thin bed of volcanic ash near the top.

Along the south side of the ridge from Dorrington to Ashford the formation is either absent or not characteristic. Near Funnel Rock the Arikaree beds lie uncomformably on the Brule clay, as shown in fig. 1\%. In the region north-northeast of. Ashford the Gering formation is very distinct again for a few miles, especially high up in the canyons which are cut into the ridge. In two of these canyons the

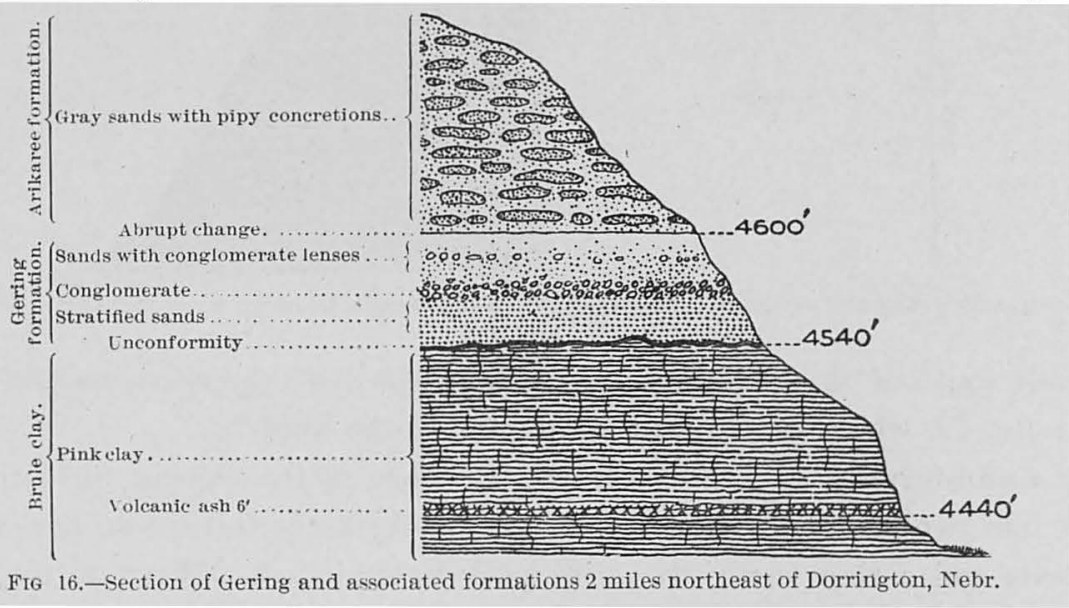

outcrop is marked by large springs. The relations in this vicinity are represented at $\mathrm{D}, \mathrm{E}$, and $\mathrm{F}$ in fig. 9 (p. 32). At $\mathrm{D}$, high up a canyon, there is a fine exposure of 50 feet of coarse Gering beds lying unconformably on Brule clay and fairly sharply separated from Arikaree beds. At E, farther down the canyon, similar relations are exhibited. At $F$, on the point at the mouth of the canyon, there is no trace of the coarse beds; the fine sand, similar to that of the Arikaree deposits, but with smaller and more widely scattered concretions, lying directly on the Brule 


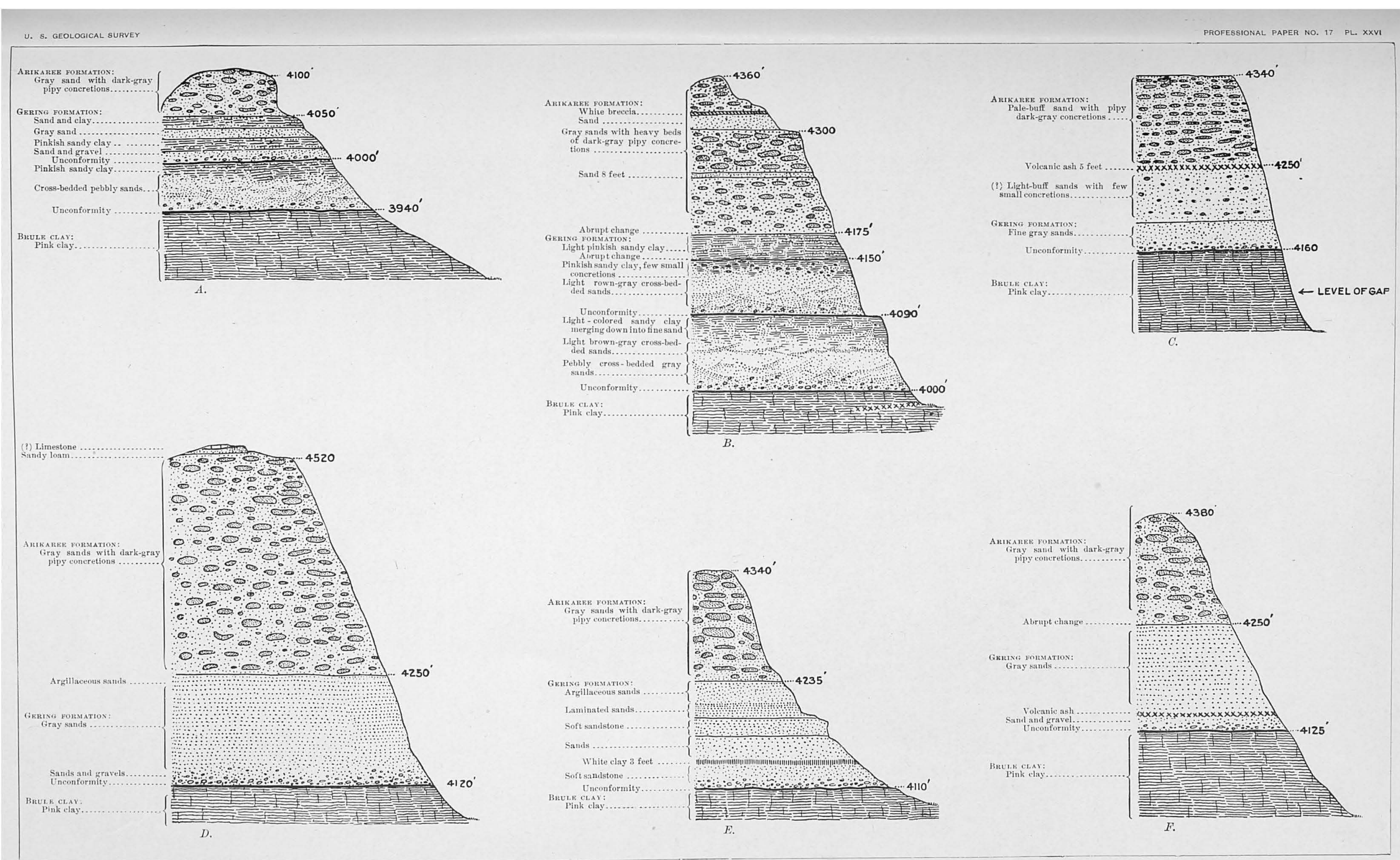

SECTIONS OF EXPOSURES SHOWING THE RELATIONS OF GERING AND ASSOCIATED FORMATIONS, CHEYENNE COUNTY, NEBR

A. At Courthouse Rock; $B$, at Birdcage Gap; $C$, at Redington Gap; $D, 4$ miles south-southeast of Chimney Rock; $E$, 3 miles south-southeast of Chimney Rock; $F, 1$ mile south of Chimney Rock. 



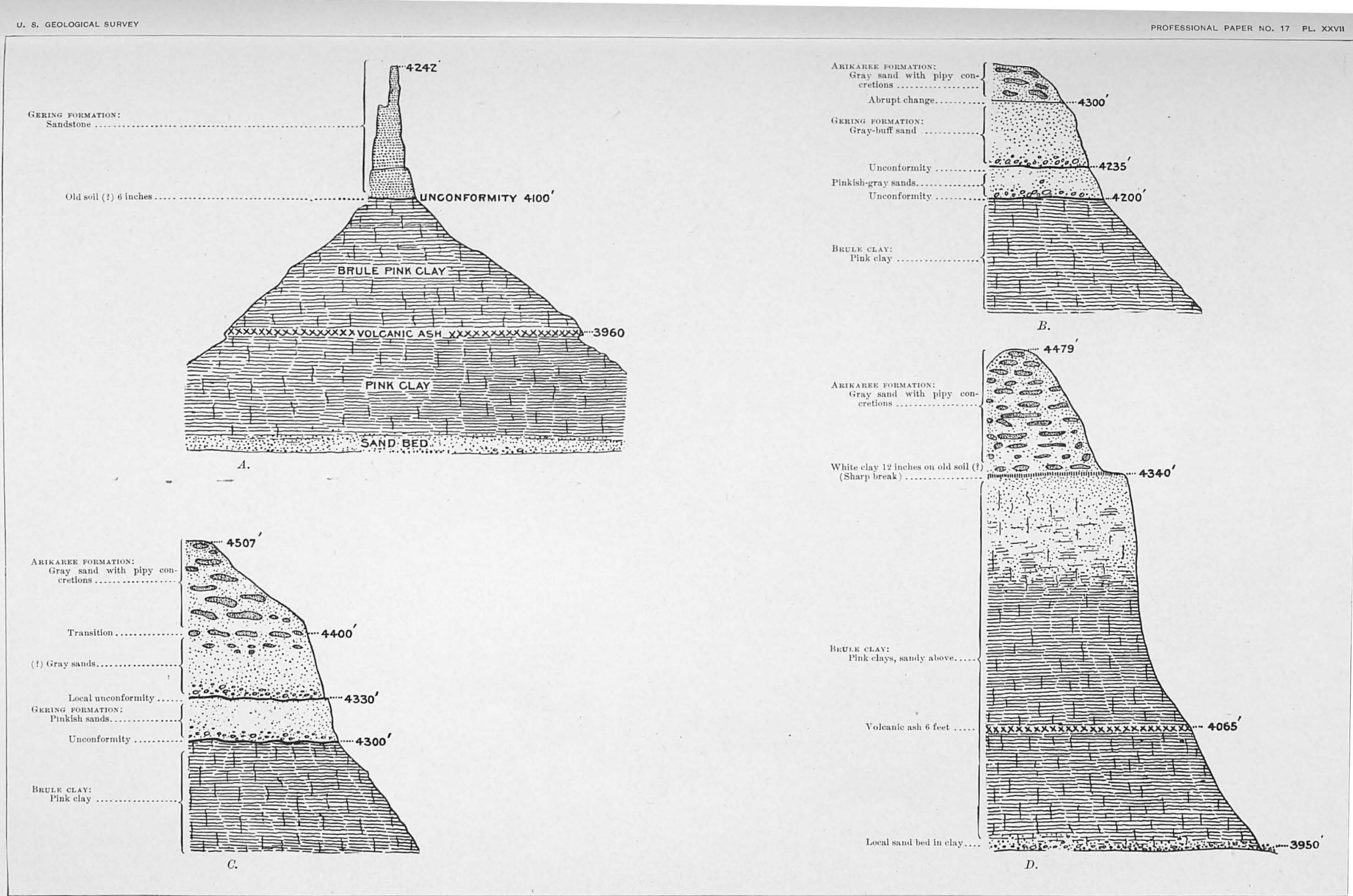

SECTIONS OF EXPOSURES SHOWING THE RELATIONS OF GERING AND ASSOCIATED FORMATIONS FROM CHIMNEY ROCK TO CASTLE ROCK.

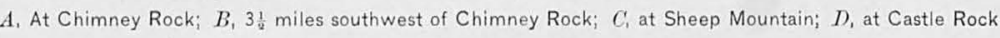



clay, with faint unconformity apparent. Farther east, at Castle Rock, in Banner County, and in the prominent point $1 \frac{1}{2}$ miles west of this rock, the identity of the formation is not satisfactorily established. The relations at these localities are shown in sections $D$ and $E$ of Pl. XXVIII. In the bluffs on the south side of the ridge, northeast of Redington, the Gering formation is again recognized. Its unconformity to the Brule clay is often finely exposed in this vicinity, as shown in Pl. XXV, $B$.

BRULE CLAY.

This thick mass of sediment which underlies the greater part of the region consists mainly of massive clay or a mixture of fine sand and clay, of pale flesh color, containing numerous fossil beds characteristic of the Oreodon series of the White River group. It is widely exposed in the valleys of North Platte River and

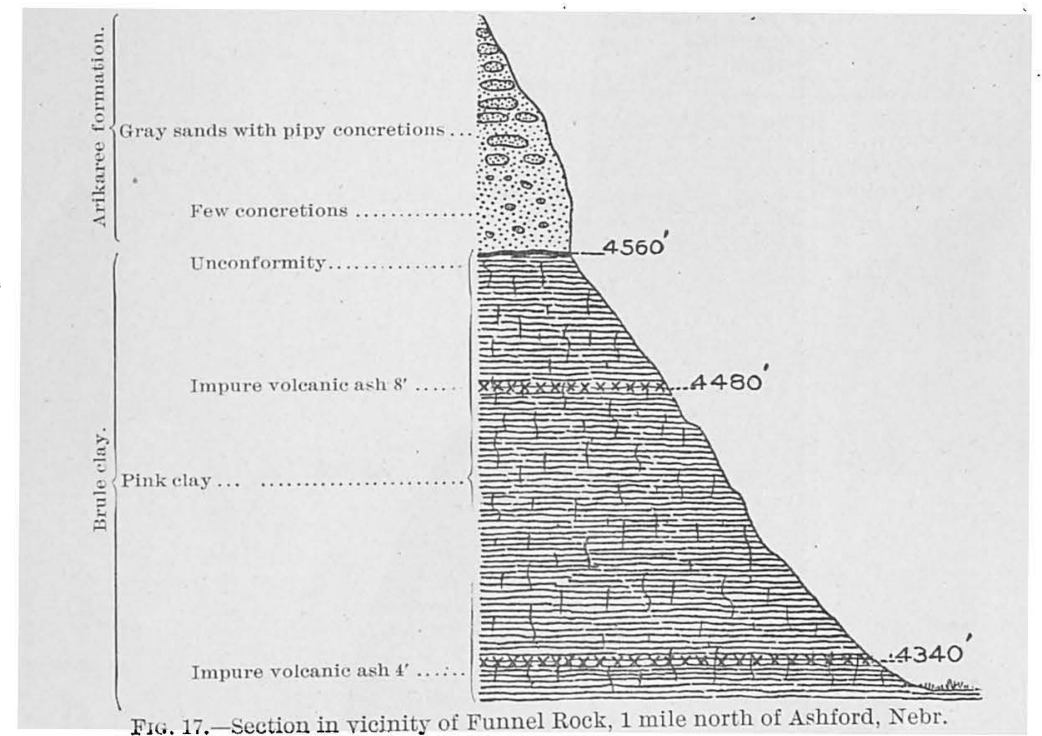

Pumpkinseed Creek, extends along the lower portion of the northern slope of Pine Ridge, and is bared in the narrow depression of Lodgepole Creek and Sidney Draw. In the valley of the North Platte it is often widely overlain by aliuvial deposits, and this also is the case to a less degree in the smaller valleys. Along the foot of Pine Ridge the formation is largely covered by wash and talus, and by a small amount of alluvium along White River and its tributaries. The formation underlies all the high table-lands, where, as shown in the sections of PI. XII, it is thickly covered by the later Tertiary deposits. North of Pine Ridge it has been deeply eroded, and beyond a narrow zone of outcrops of the underlying Chadron beds the Pierre clay succeeds as the surface formation. There are extensive exposures of the Brule clay in the northern face of Scotts Bluff, where, from the base of the overlying Gering beds to the river, there is a vertical interval of 500 feet of continuous outcrop, and 
the formation has a small additional thickness below the level of the river. (See Pls. XXX and XXXI.) Along the northern front of Pine Ridge the formation averages 600 feet in thickness, but beginning near Crawford it gradually thins to the east to about 350 feet in the vicinity of Chadron. In Round Top, just west of Adelia, there are 655 feet of Brule beds.

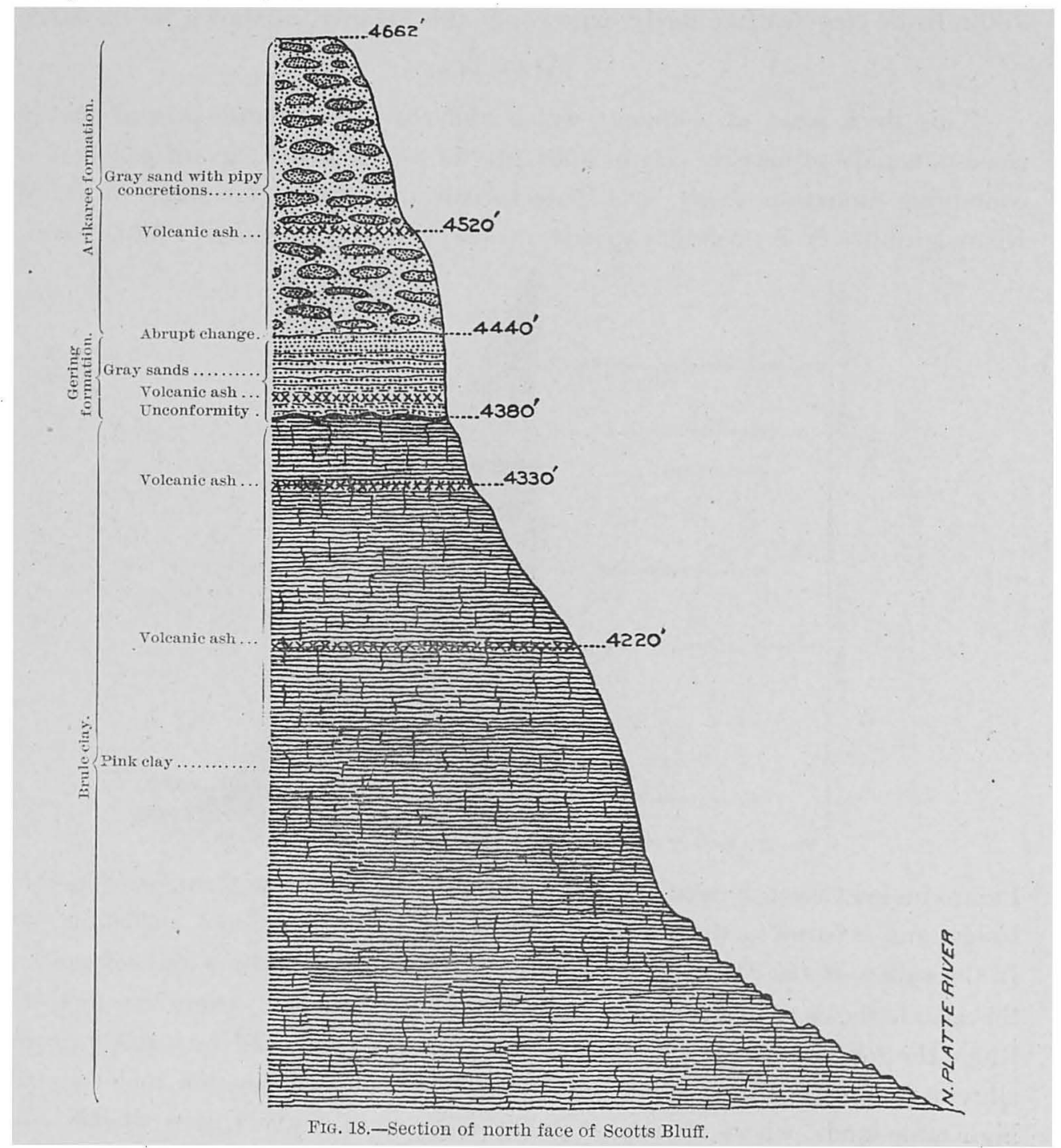

In the region southeast of Gering the Brule formation contains a bed of coarse material which appears to extend several miles. It consists of coarse, cross-bedded sand and conglomerate lying about 120 feet below the top of the formation. The thickness varies from 10 to 80 feet, the thickest portion appearing in canyons and buttes 5 to 6 miles south of Gering. The relations in this vicinity are illustrated in fig. 9. (p. 32), 
U. S. geoLogical sURVEY
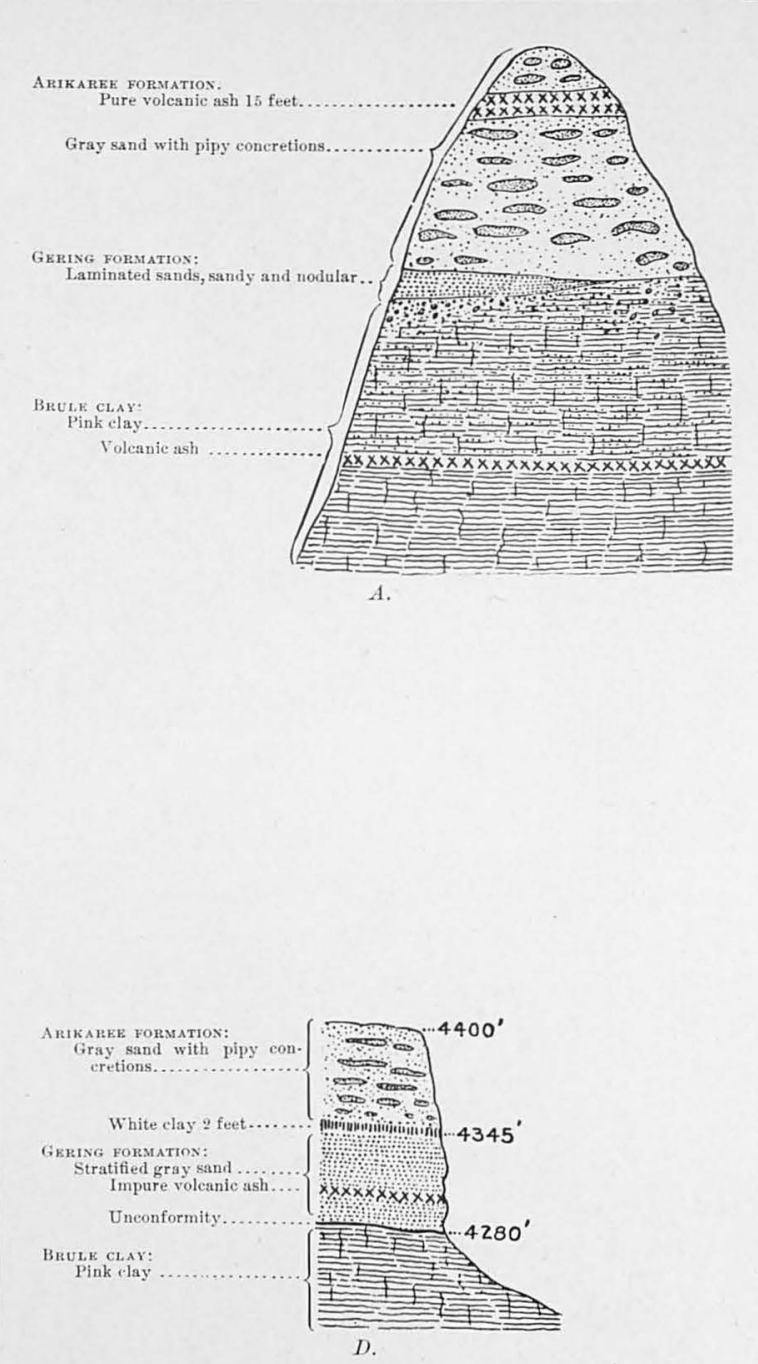
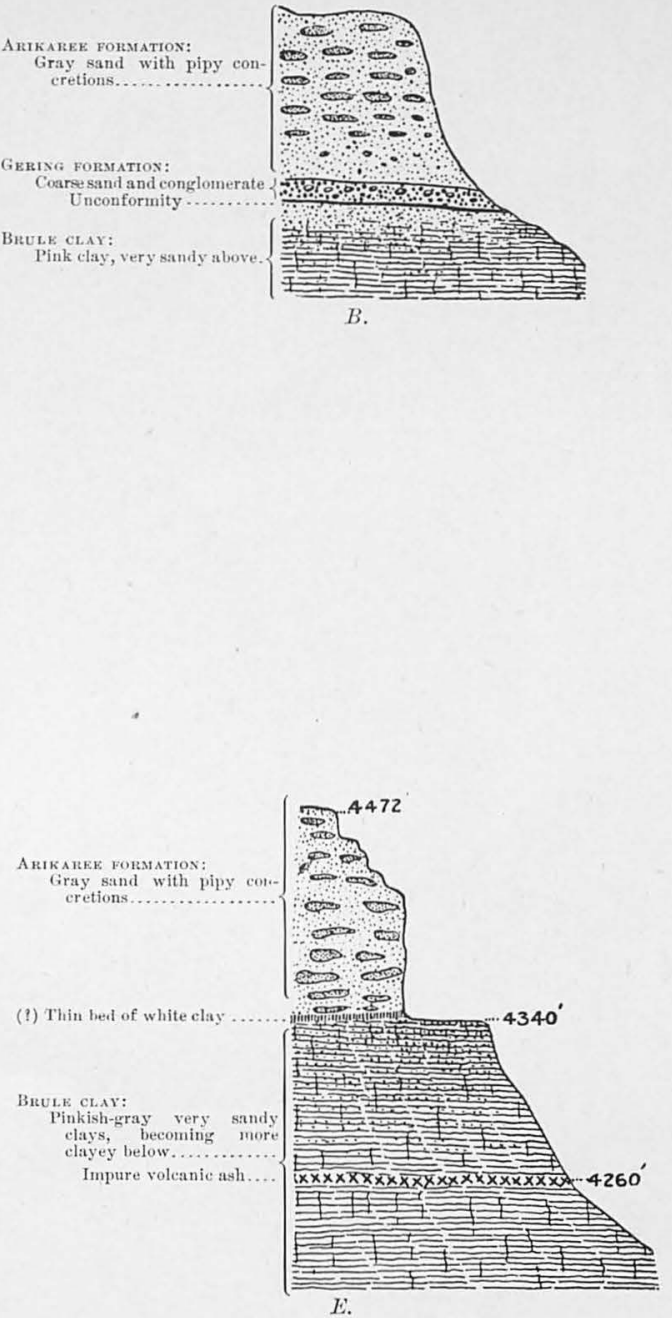
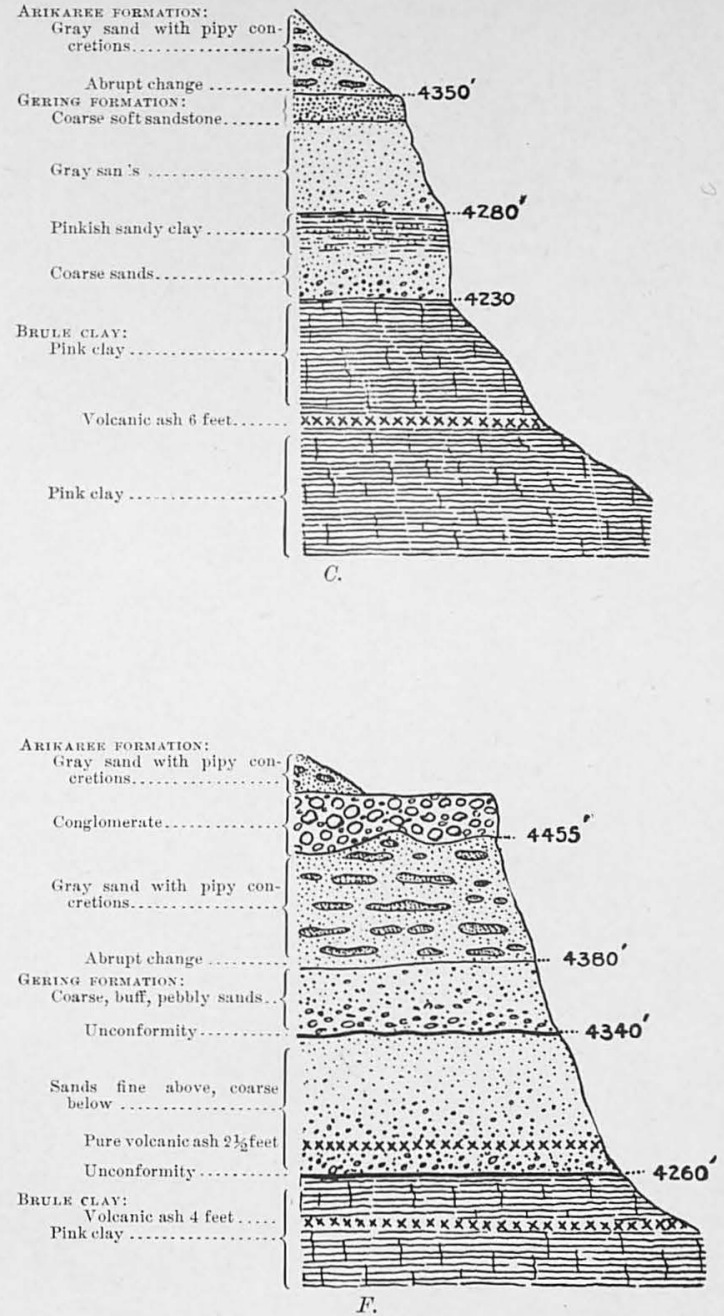

SECTIONS OF EXPOSURES SHOWING THE RELATIONS OF GERING AND ASSOCIATED FORMATIONS SOUTH AND SOUTHWEST OF LARISSA, NEBR.

A. $2 \frac{1}{2}$ miles west-southwest of Larisssa; $B, 3$ miles southwest of Larissa; $C, 2 \frac{1}{2}$ miles south-southwest of Larissa; $D, 2$ miles west of Castle Rock, Banner County; $E_{1}$ at Castle Rock. Banner County; $F, 3$ miles south of Larissa. 



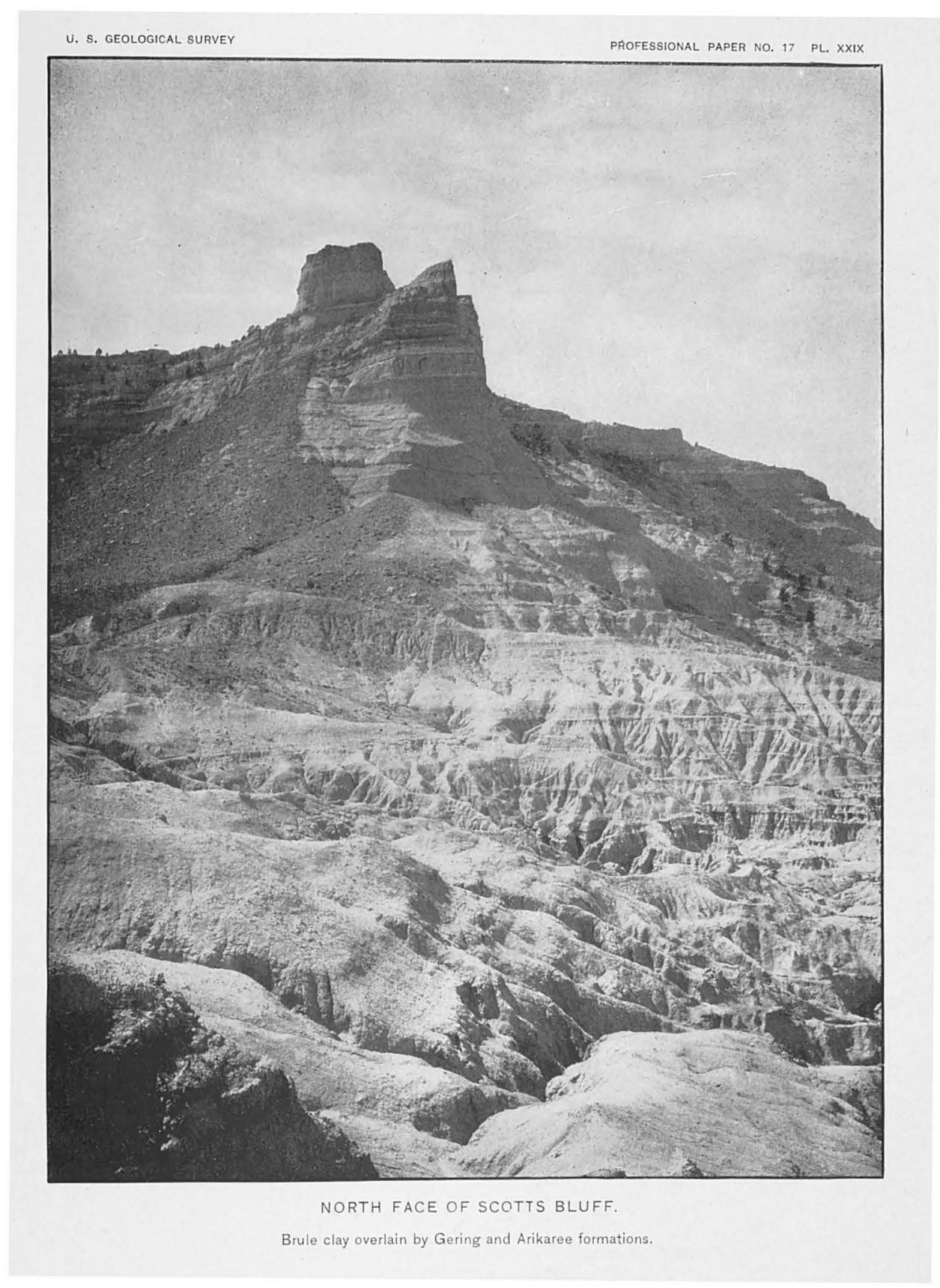



and one of the finest exposures is shown in Pl. XXXII, $B$. There are other exposures north of Larissa and northeast of Chimney and Castle rocks, as shown in

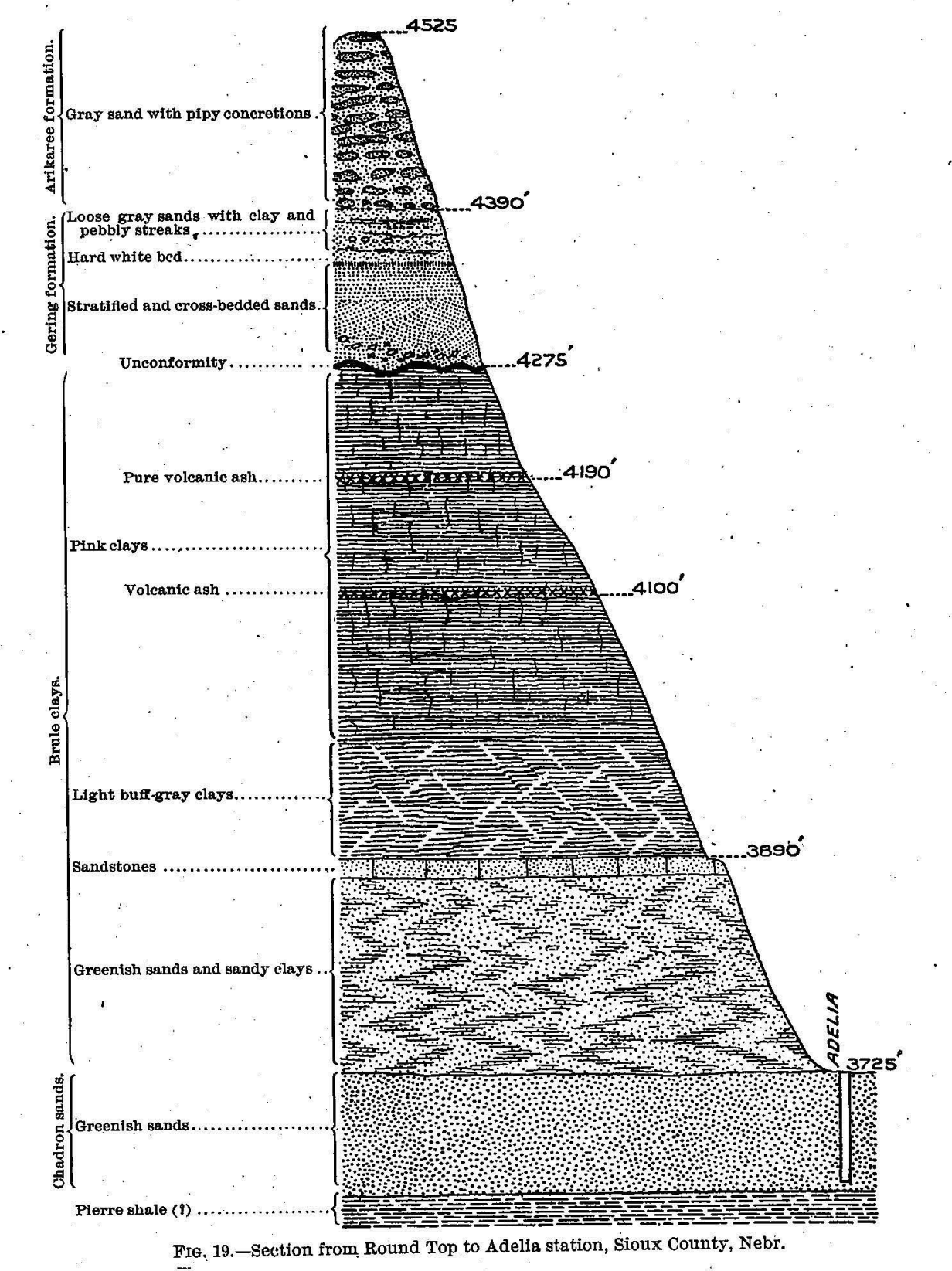

sections $A$ and $D$ of Pl. XXVII. In the area near Larissa and south of Gering there is near its base a thin bed of very compact limestone, which again outcrops north of Sunflower. 
In the badlands about Adelia station on the Burlington and Missouri River Railroad there are extensive exposures of the Brule and associated formations. (See Pls. XXXIII and XXXIV and fig. 19.)

This section closely resembles the typical section in the Big Bad Lands in South Dakota, but appears to include some higher beds. The alternate greenish and pinkish clays with brown nodular layers lying on the Chadron sands are similar to the Oreodon series and yield many of the same mammalian remains. The sandstone next above probably represents the Metamynodon series, and in it was found a fragment of a tooth, probably of Metamynodom. The overlying clays can be less definitely

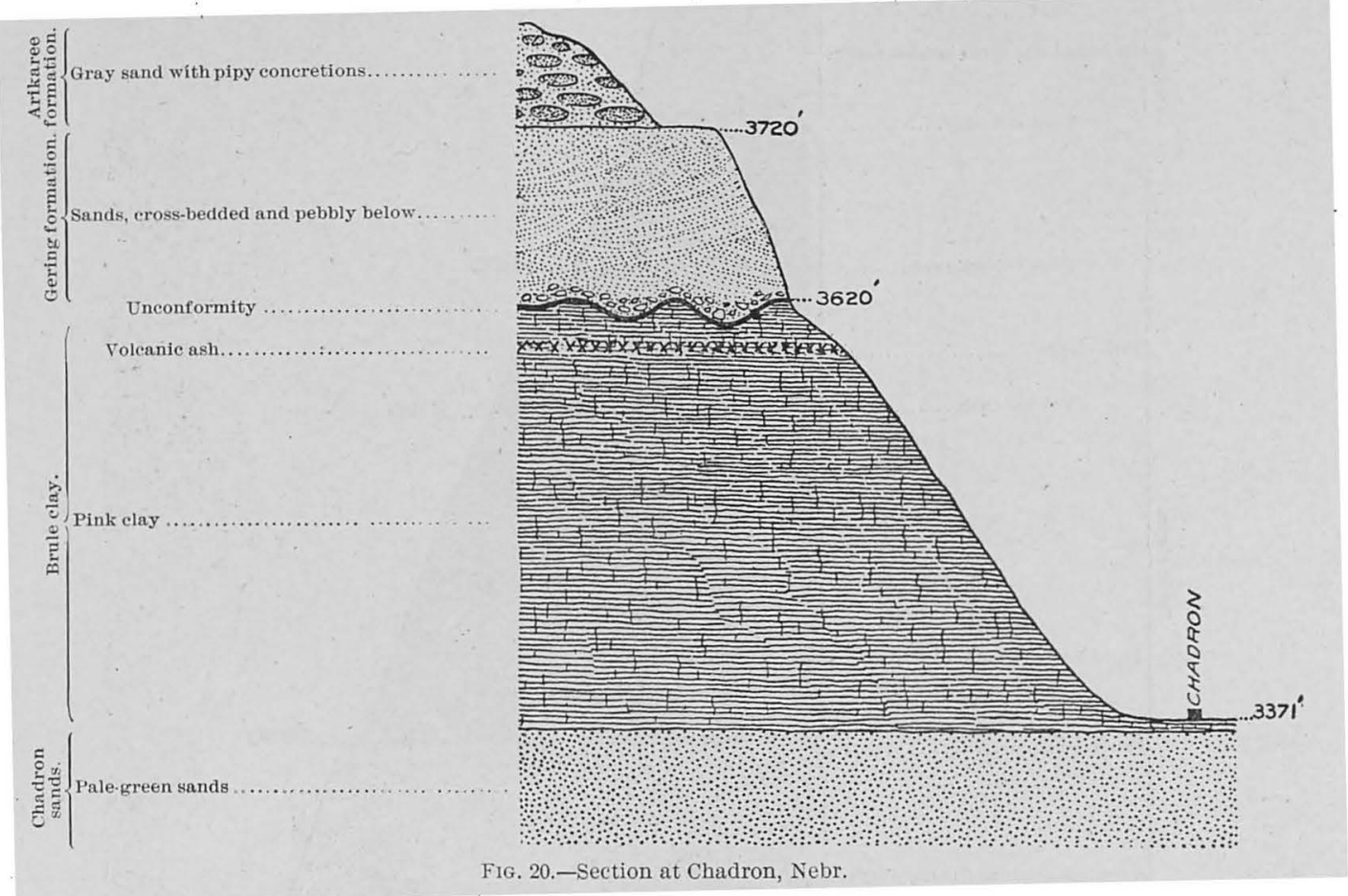

correlated, especially those toward the top, which $\mathrm{I}$ believe are higher than the highest beds represented in the Big Bad Lands. They contain two beds of volcanic ash, the upper one 12 feet thick, of nearly pure material, in tlat, glassy scales, not so vesicular as usual. Along the eastern extension of Pine Ridge the intermediate beds, those extending from 4,000 to 3,725 feet in the Round Top section, soon thin out, and the Chadron formation is overlain by the flesh-colored clay, with its volcanic ash layer near the top. A section at Chadron is given in tig. 20.

CHADRON FORMATION.

This basal formation of the Tertiary series outcrops in a narrow zone along the lower slopes north of Pine Ridge, just outside the margin of the overlying Brule 


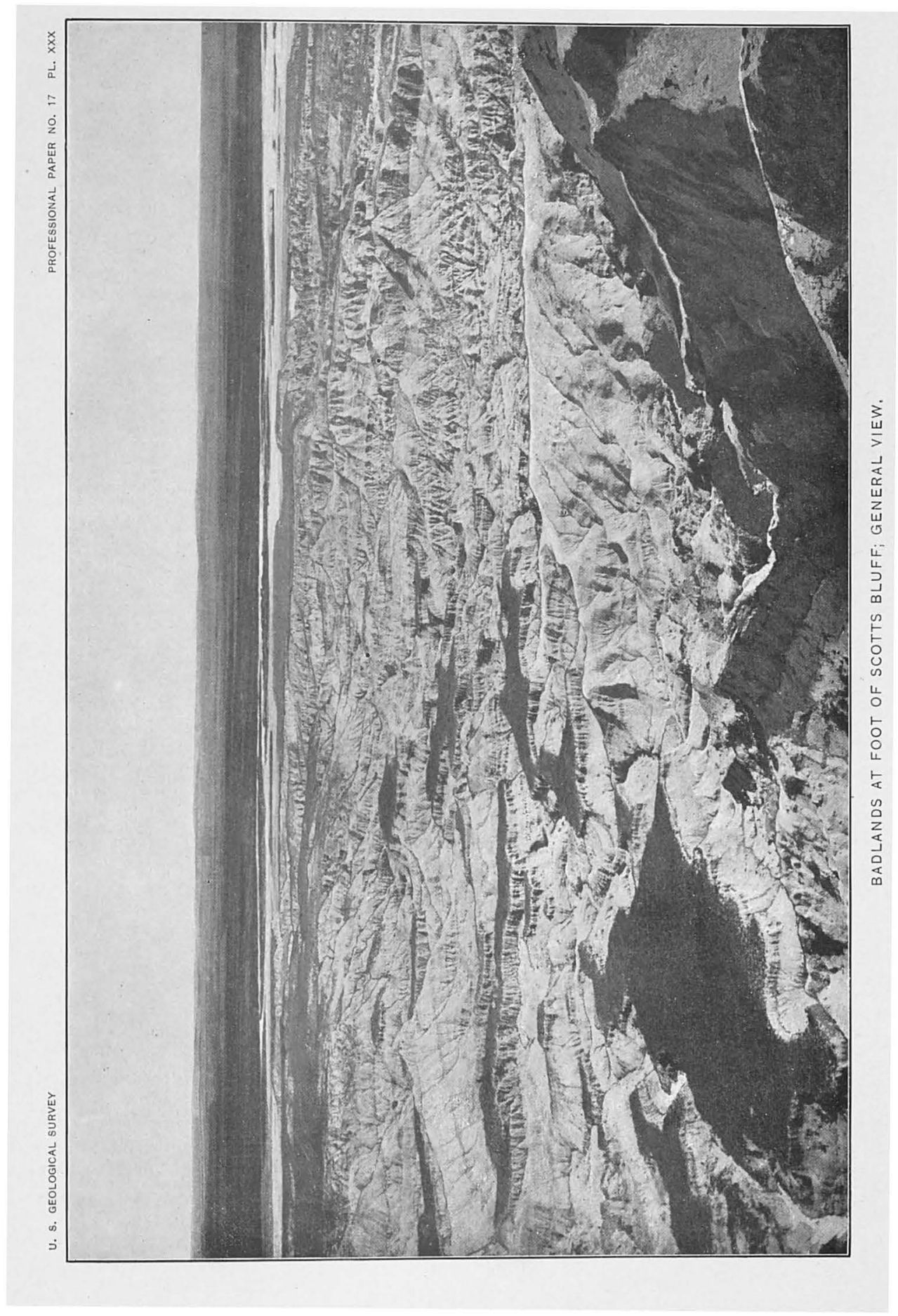





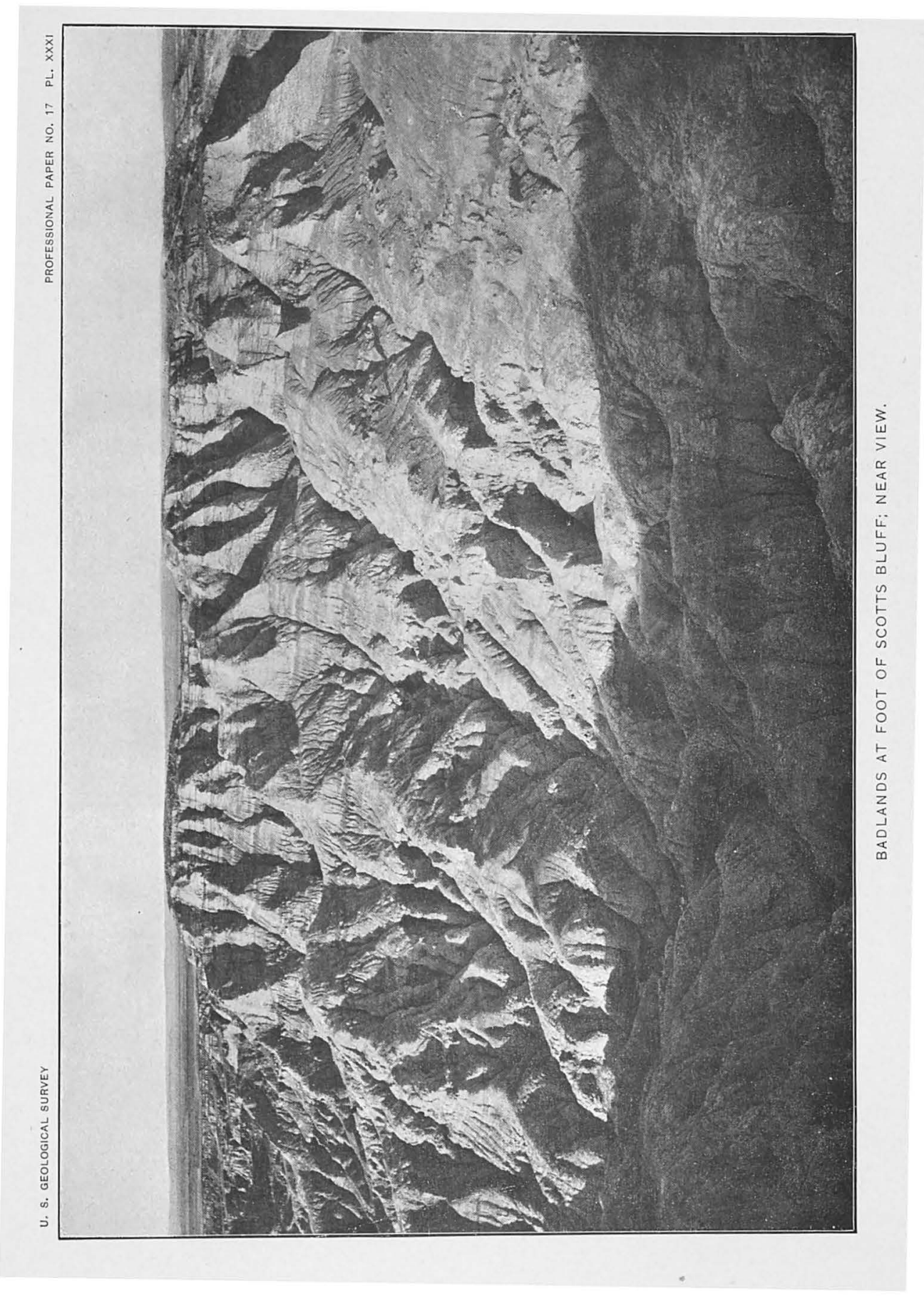



clays. There is also a small area of outcrop in the valley of North Platte River in the vicinity of Caldwell and Mitchell. The deposits have heretofore been known as the "Titanotherium beds," from the frequent occurrence of remains of several species of a large mammal which has been named Titunotherium. As the large bones and peculiar teeth of this animal are very distinctive features, an illustration of a skeleton is reproduced in Pl. XXXV. The predominant material of the formation is sandy clay of light greenish-gray color, usually with coarser beds at the bottom, including deposits of gravels often several feet thick. The beds above these gravels are often of bright dark-red color, notably in the region about Adelia. The thickness of the formation varies from 30 to 60 feet in the outcrops along the foot of Pine Ridge. , It thickens considerably in the vicinity of Adelia, where there are included some masses of dark-gray and buff sandstone of coarse texture. At many points around its outer margin the Chadron sands may be seen lying on the irregular, black, or generally rusty surface of the Pierre shale.

LARAMIE FORMATION.

The Laramie formation is exposed in an area of considerable extent in Goshen Hole, which extends for a short distance eastward into Nebraska on the north side of Horse Creek west of Caldwell and on a branch of that creek 5 miles southwest of Caldwell. The rock is a soft greenish-buff to brownish sandstone. Its surface is irregular; to the north it is overlain by Chadron beds and to the south it rises into the base of the Brule clays. Doubtless it extends for some distance east, but its eastern margin was not ascertained.

\section{PIERRE CLAY.}

The entire region to which this report relates is underlain by the Pierre clay, a thick mass of dark-colored clays or shales constituting the upper member of the Cretaceous formations in some portions of the Plains. Possibly under the southwest corner of Nebraska the Tertiary formations are underlain by the edge of the Laramie formation-a series of. sandstones higher in the Cretaceous-but of this there is at present no evidence. The Pierre shale outcrops in the northern portion of Sioux and Dawes counties, as shown in Pl. XI. The surface of the formation rises somewhat with the general upward slope of its beds toward the Black Hills uplift, and it is exposed by the erosion which has removed the Tertiary formations over the lowlands extending from the valleys of White River and Hat Creek to the foot of the Black Hills. The dark shale gives rise to a rolling region of scant vegetation and poor water supply. Exposures are frequent, and the dark-yellow or rusty surfaces due to the oxidation of the iron pyrites in the shale are characteristic features of the area.

Distinctive fossils of numerous marine mulluscan species are abundant in the 
Pierre clay. The fossils are often preserved in concretions of gray siliceous matter of lenticular form, which abound in the upper portion of the formation. The precise thickness of the Pierre shales is not known, but it probably exceeds 1,200 feet.

NIOBRARA LIMESTONE.

The Pierre shale is underlain by the Niobrara limestone, but this formation does not reach the surface in the portion of Nebraska west of the one hundred and third meridian. As, however, it would be reached by deep borings for artesian water, some of its characteristics should be pointed out. Its thickness is about 50 feet. It consists mainly of massive dark-gray chalk or soft limestone, which weathers to a buff or light-cream color when exposed to the atmosphere. The formation can be readily recognized by the very distinctive fossil Ostrea congesta, which is nearly always present in abundance in thin, hard layers. In order to aid the well driller in identifying this formation in borings, an illustration of this fossil is introduced in Pl. XXXVI.

BENTON FORMATION.

Underlying the Niobrara limestone and abruptly separated from it are the Benton shales, which have a thickness of 1,500 feet. They contain thin layers of sandstone and limestone; one of the latter, about 900 feet above the Dakota sandstone, is filled with the Inoceramus shown in Pl. XXXVI. The formation lies far below the surface along the South Dakota line, but outcrops extensively in the vicinity of Edgemont, having the relations shown in fig. 21.

\section{DAKOTA SANDSTONE.}

This is the water-bearing sandstone of South Dakota and northeastern Nebraska, and it underlies all the region to which this report relates. It is a gray or brownish sand rock; occurring in thick beds, with intercalated lenses of shale or clay and occasionally thin seams of coal. Its relations in the northern part of the area are shown in fig. 21 and Pl. X. Its lower beds are of Lower Cretaceous age.

VOLCANIC ASH.

In studying the geology of this region it was found that several formations contained extensive deposits of volcanic ash. Some of this material was found in the Chadron formation; two very widespread beds occur in the Brule clay; lenses of the ash are often included in the Gering formation; and there is a general admixture of ash as well as a number of thick beds of it in the Arikaree formation. So far as observed it is rare in the Ogalalla formation. In the central and eastern portion of the State it occurs mainly in the lower portion of the loess.

The ash deposits are usually more or less mixed with clay or sand, but there are many beds in which the deposits are thick and pure. They promise to have considerable commercial value, mainly for polishing powder. 


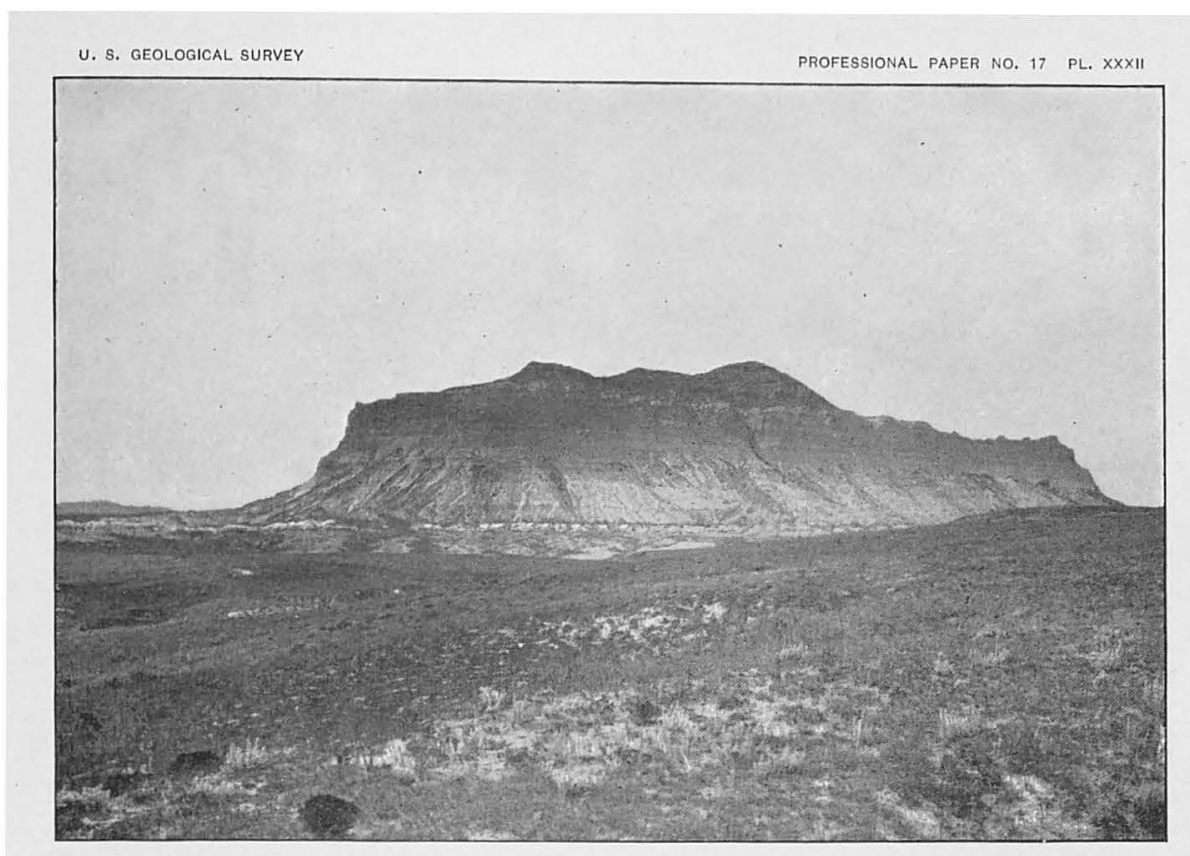

A. CASTLE ROCK, SCOTTS BLUFF COUNTY, NEBR., FROM THE EAST, SHOWING BED OF VOLCANIC ASH NEAR THE FOOT OF THE SLOPE.

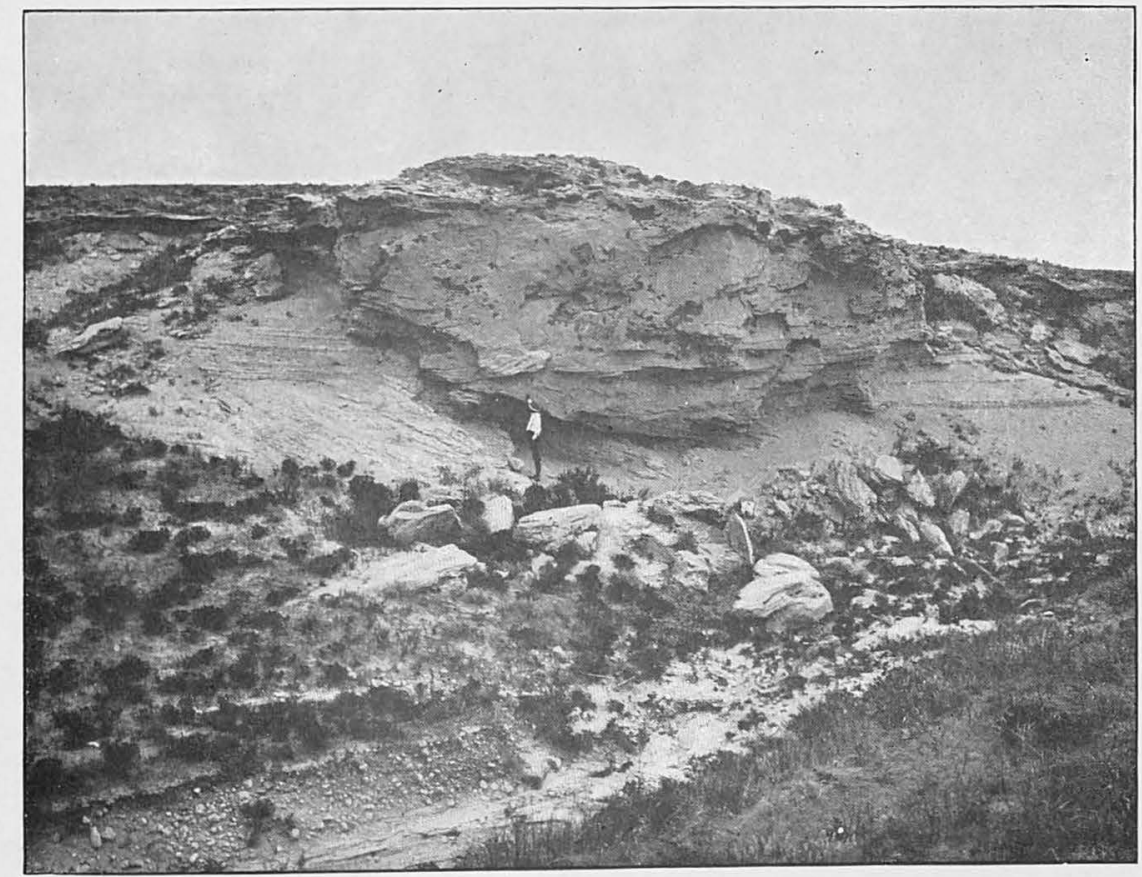

B. LENS OF COARSE MATERIAL IN BRULE FORMATION, 4 MILES SOUTH OF GERING, NEBR. 



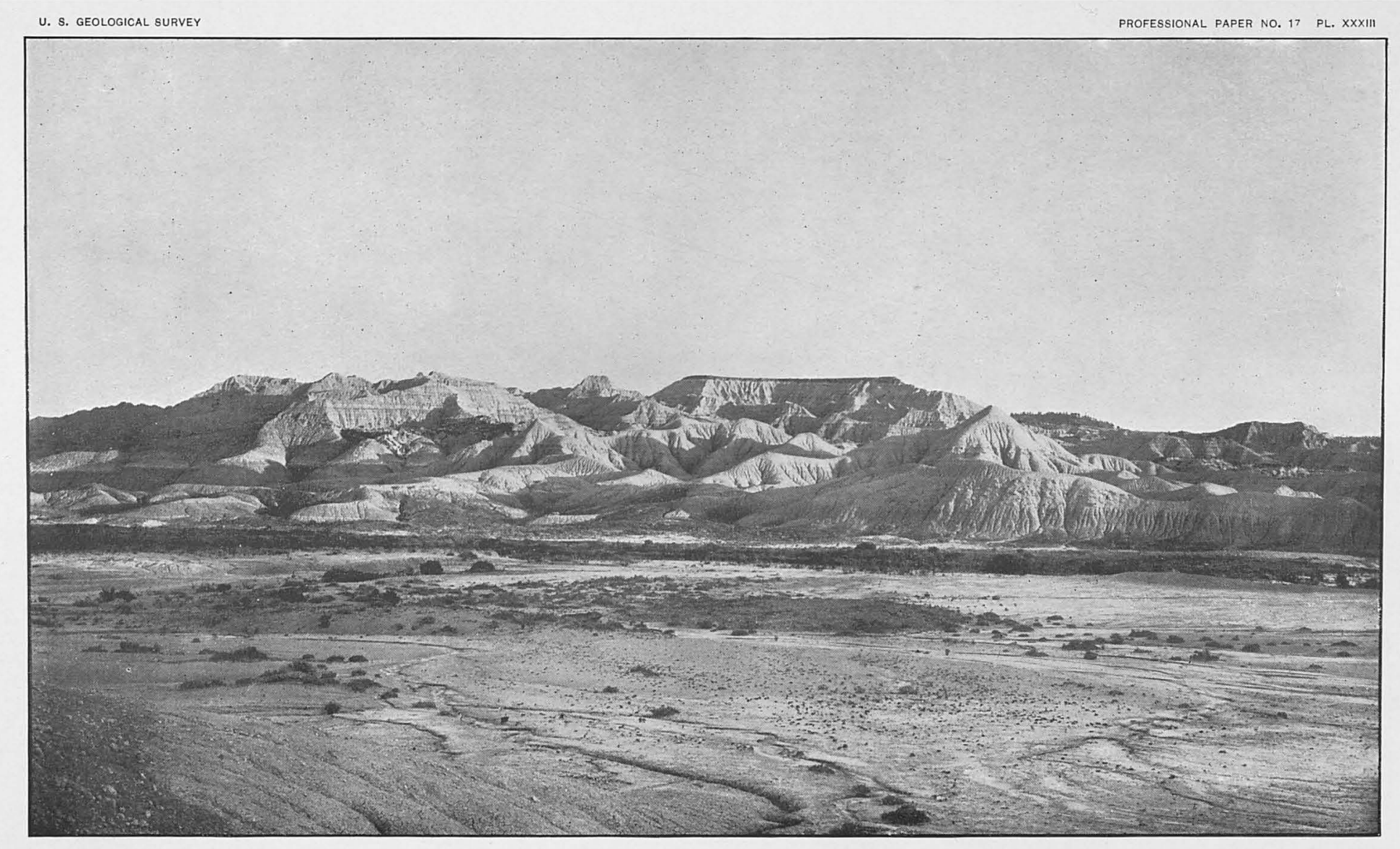

BADLANDS OF BRULE FORMATION, WEST OF ADELIA, SIOUX COUNTY, NEBR; LOOKING NORTHWEST. (From photograph by $E$. H. Barbour, University of Nebraska.) 

The most persistent layer is in the Brule clay, at an average distance of about 70 feet below its top, in the ridge next south of North Platte River. This bed is shown in Pl. XXIV and Pl. XXXII, A. A lower bed, usually much less pure, occurs from 80 to 100 feet below the upper one. On the north side of Pine Ridge these two horizons are recognized in some of the higher beds in Sowbelly Canyon and at Round Top and near Chadron, as shown in figs. 19 and 20. The volcanic asb occurring in the Gering formation is usually restricted in extent and variable in relations. It is, however, often exceptionally pure.

The Arikaree formation contains a sprinkling of ash almost throughout its extent. In some of the bluffs southwest of Gering a thickness of 100 feet of sandy clays of this formation was observed, which contains a fairly large proportion of ash. In the high isolated hutte 3 miles west by south from Larissa there is a 15 -foot bed of nearly pure ash, with pipy concretions scattered through it, in the midst of the Arikaree formation. In Wildcat Mountain beds of ash were found at intervals nearly to the cap of Ogalalla formation. The formation contains a large admixture of ash in the vicinity of Fort Robinson and again at Round Top, near Adelia, as shown in fig. 19 (p. 39).

The ash in these formations was probably derived from rolcanoes in the Rocky Mountain region, for there is no evidence of Tertiary volcanoes in the vicinity. The ash was undoubtedly borne on the winds and deposited in the waters which laid down the several Tertiary formations. When the ash came in large volume, or there was very little other sediment, pure deposits resulted; but ordinarily there was considerable admixture of the fine sand and clay.

\section{UNDERGROUND WATERS.}

GENERAL CONDITIONS.

The relations of underground waters in this region present a variety of features. In many localities there are large supplies at moderate depths, and in other places the amount of waters in reach of the average farmer is so small as seriously to interfere with the settlement of areas of considerable extent. This has been particularly the case where large volumes of water were needed for cattle. The greatest difficulty in obtaining water has been in the area of the Brule clay back from the rivers and in the region underlain by Pierre clay. In the flats adjoining the river in Platte Valley and in Lodgepole Valley water supplies are usually obtained in wells from 10 to 40 feet in depth. On the table-lands on both sides of Lodgepole Valley waters are obtainable in large volume from wells from 150 to 300 feet deep, the depth increasing gradually westward. In Niobrara Valley supplies of water are obtained from shallow wells in the narrow strip of alluvial deposits near the river, and farther back on the table-land plenty of water is found at depths varying from 50 and 100 feet on the lower slopes to 300 feet in some of the 
highest areas to the northwest. In the sand hills water accumulates in basins at moderate distances below the surface, so that shallow wells ordinarily obtain satisfactory supplies.

Along the outer edge of the Brule clay area north of Pine Ridge water is usually found in the underlying Chadron sands. In PI. XXXVI are shown the depths to water supplies in the western Nebraska region, based on observations of the water level in wells and springs and determinations of the geologic relations of the waterbearing formations.

WATER HORIZONS.

In the alluvial formations along Platte, Niobrara, and $W$ hite rivers and Lodgepole; Pumpkinseed, Snake, and Hat creeks, and some of their branches, the water supply constitutes an underflow. Along the Platte this underflow is of large volume, but in some areas the water is somewhat alkaline. In the Pumpkinseed Valley at some localities, and in the greater portion of the White River and Hat Creek valleys, where they traverse the Pierre shales, these water supplies are often unsatisfactory both in quantity and in quality.

The next horizon is at the base of the Ogalalla formation, which supplies water for many wells on the table-lands on both sides of the Lodgepole Valley at depths varying from 100 to 300 feet. The volume of water appears to be large at nearly all localities. At some places the waters are obtained high up in the formation, but the principal supplies are in the basal beds. At many points along the northern margin of the table-land these waters flow out into the canyons as springs of greater or less force, of which the most noteworthy are those on Greenwood, Middle, Hackberry, and Bighorn creeks, in Lawrence Fork Canyon, and at Gabe, Long, and Duggers springs.

The Arikaree formation is a general reservoir for water, which is nearly everywhere available in the table-lands lying between the valley of North Platte River and the crest of Pine Ridge. In some areas it is necessary to sink wells to the base of the formation, where the materials are somewhat coarser than those higher up, but ordinarily the higher beds yield satisfactory supplies. These waters flow out at the surface in springs of greater or less magnitude in many canyons along the front of Pine Ridge; at a few widely scattered points in the Niobrara Valley, notably at Coyote Spring and at Royville; in the Snake Creek Valley, at Point of Rock Spring: and Mud Spring; and along the north slope of the Platte Valley, at the spring near the head of Sheep Creek and the springs near the heads of Red Willow and Indian creeks.

The Gering formation contains water throughout its area, but it does not appear to be reached by many wells. Numerous springs on the ridge south of North Platte River flow from this formation at the surface of the Brule clay. Along the front of Pine Ridge there are a number of springs which flow out of these beds, and possibly 


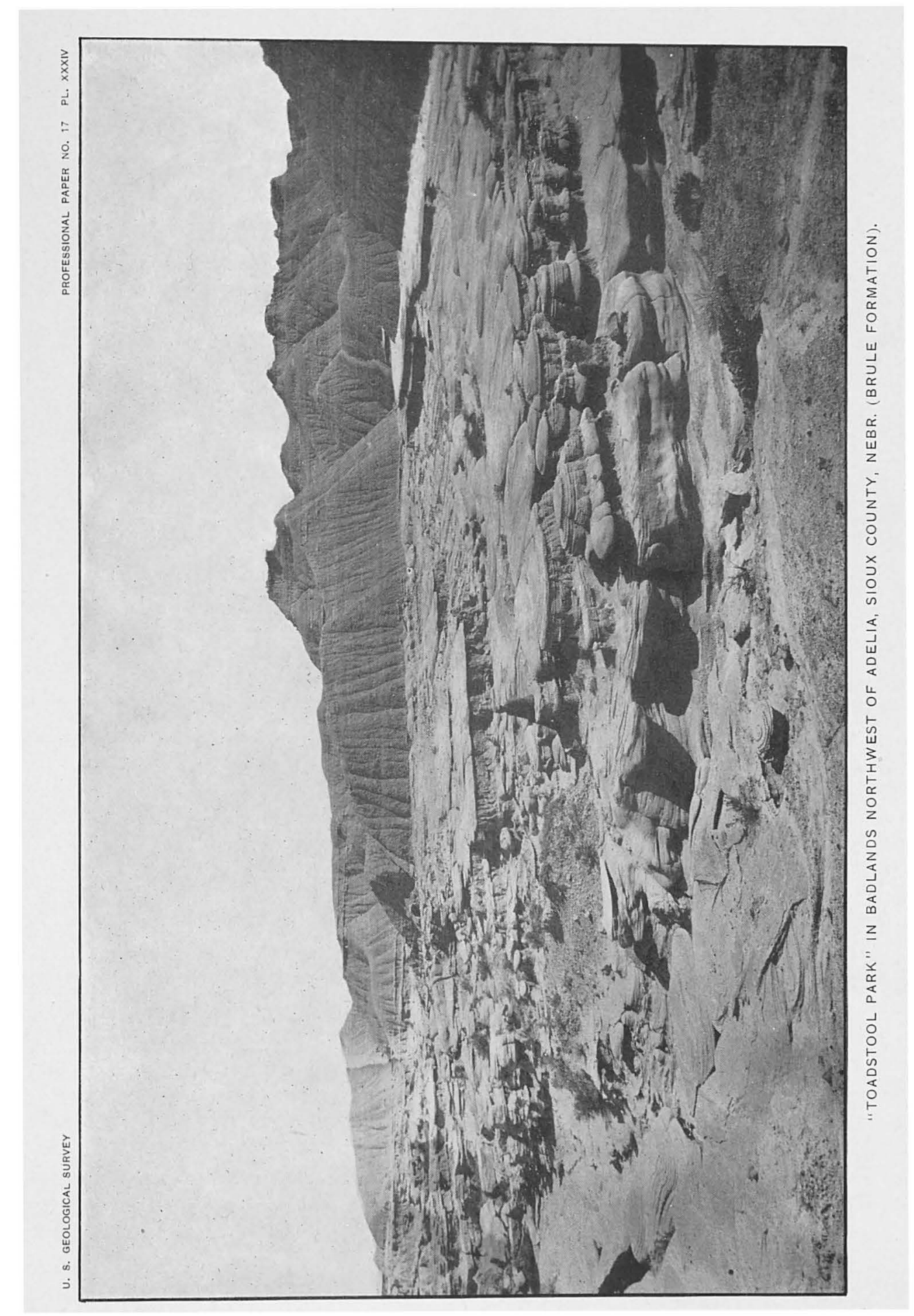





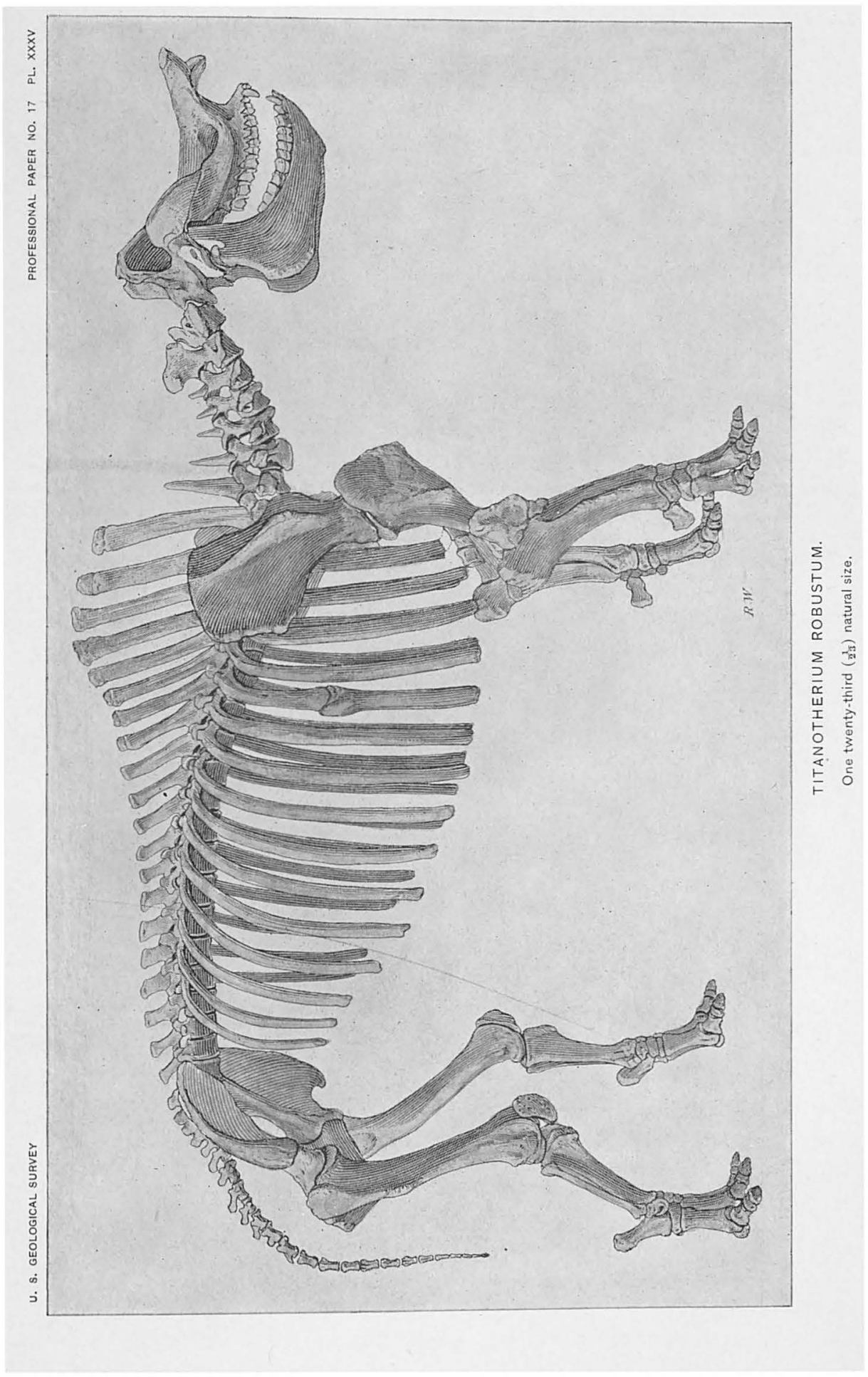



some of the deeper wells on the summit of Pine Ridge obtain their water from this horizon, but ordinarily ample supply is reached at a less depth in the overlying Arikaree formation.

The Brule clay immediately underlies a wide area of the high slopes of the North. Platte and Pumpkinseed valleys and yields water supplies to many wells. It is known as " hardpan" to the well drillers. In most cases, however, the volume of the water is.small, and its quality is often unsatisfactory. Numerous abandoned houses in these valleys usually indicate that prospective settlers have been unable to obtain water supplies at moderate depths from the Brule clay. Where water occurs it is in crevices and fissures, which traverse the clay at moderately frequent intervals, but the volume of water depends on many factors, and there is seldom a good chance to obtain a large supply. In the area north of Pine Ridge the wells usually penetrate through the Brule clay into the underlying Chadron sands, which almost invariably contain fairly large volumes of water. It is a source of supply. to a number of farmers and ranches. The water is not always of satisfactory quality, and in the wells at Adelia and Crawford it has been found unsuitable for locomotives: This formation underlies the Brule clays in the Platte and Pumpkinseed valleys, and probably would often yield water there to wells a few hundred feet in depth. Some years ago a well: was sunk at Gering to a depth of 331 feet, which obtained a promising flow of water, probably from the Laramie sandstone, which underlies the Chadron formation. Owing to the small size of the pipe and to accidents in boring, the well did not continue to flow, and clogged up so that it was a failure. As water supplies are particularly scant in the region about Gering and in the valleys to the south, it is very unfortunate that this boring was not given a fair trial. At Harrisburg, on the south slope of Pumpkinseed Valley, a boring has recently been made to a depth of 790 feet without obtaining a flow. Judging from the small samples of the borings which were seen, the well passed through the Chadron sands and entered the Laramie formation for several hundred feet, but it did not obtain a sufficient supply of water. It is known that the edge of the Laramie formation extends into southwestern Nebraska under the Chadron sands, and it should be expected to yield a water supply that would rise to an altitude of about 4,500 feet. In the underlying Pierre shale there are no chances for water. In the area in which this formation is at the surface, in northern Sioux and Dawes counties, great difficulty has been experienced in obtaining water supplies for local use, and the water found has generally proved to be of unsatisfactory quality.

DEEP-SEATED WATERS.

In the older formations which underlie Nebraska there are widespread sheets of permeable deposits which carry large volumes of water. In the region to the west 
these deposits lie at great depth, and many of the higher-lands are probably above the level to which the waters would rise to afford surface flows. Owing to the failure of any boring in the central and western portion of the State to reach the deep-seated water-bearing beds, there is lack of definite knowledge as to their depth, but there can be no doubt of their presence. The section constituting Pl. X illustrates the general relations of the two principal deep water-bearing formations-the Dakota sandstone and the Carboniferous and underlying limestones. In eastern South Dakota the Dakota sandstone yields to many wells large volumes of excellent water under high pressure. In eastern Nebraska, where the formation approaches the surface, it is also the source of water supply, at first to wells of moderate depth and then to innumerable springs. The Carboniferous and underlying formations yield water to numerous wells between 650 and 1,500 feet deep in eastern Nebraska and Iowa. These waters pass into the formations along the foothills of the Black Hills and the Rocky Mountains at altitudes of from 3,000 to 6,000 feet in greater part, and

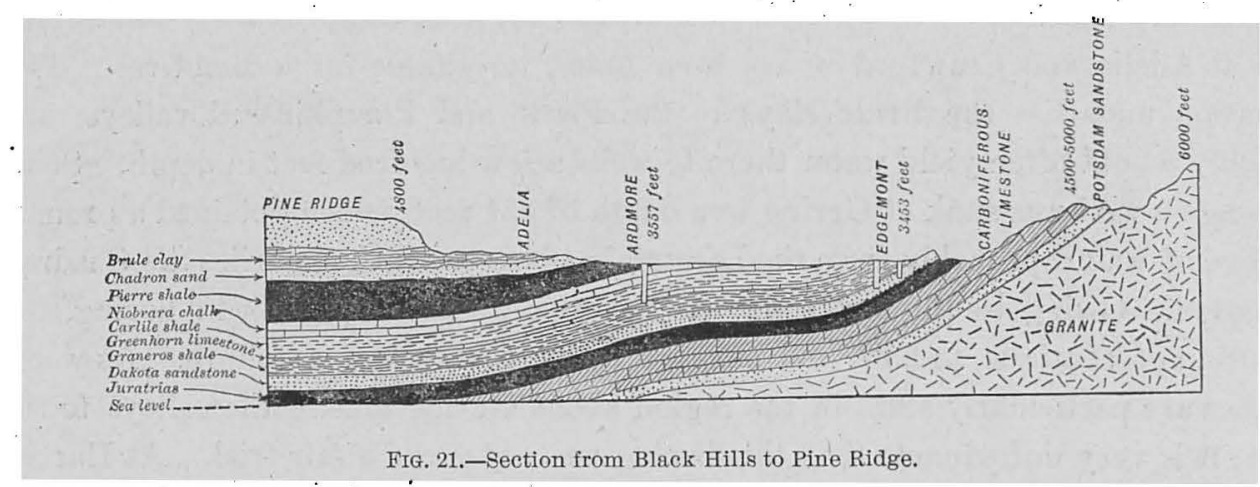

have considerable pressure and head far to the east. This pressure and head, however, gradually decrease as the formations reach or approach the surface, the water then being free to escape. The waters in the Dakota sandstone lose their head entirely in eastern Nebraska, where the formation outcrops. The waters in the underlying Carboniferous limestones and older formations retain a moderate amount of head throughout Nebraska. Some of the factors bearing on the occurrence of these deep underground waters are shown in PI. XXXVIII, and in PI. XXXIX are shown some of the conditions of occurrence of the waters in the Carboniferous and underlying formations in the vicinity. of Omaha, Nebr. It will be seen in PI. XXXIX that the head is relatively constant near 1,100 feet above sea level over a wide area about Omaha, but there is a slight rise to the west even in a few miles. At Lincoln it is 1,210 feet above sea level. The increase of head and pressure to the west and northwest is gradual, for the distance is great, but the amount becomes large as the Black Hills and Rocky Mountain zones of intake are approached. In PI. XXXVIII figures are given showing the altitudes along these zones and along 


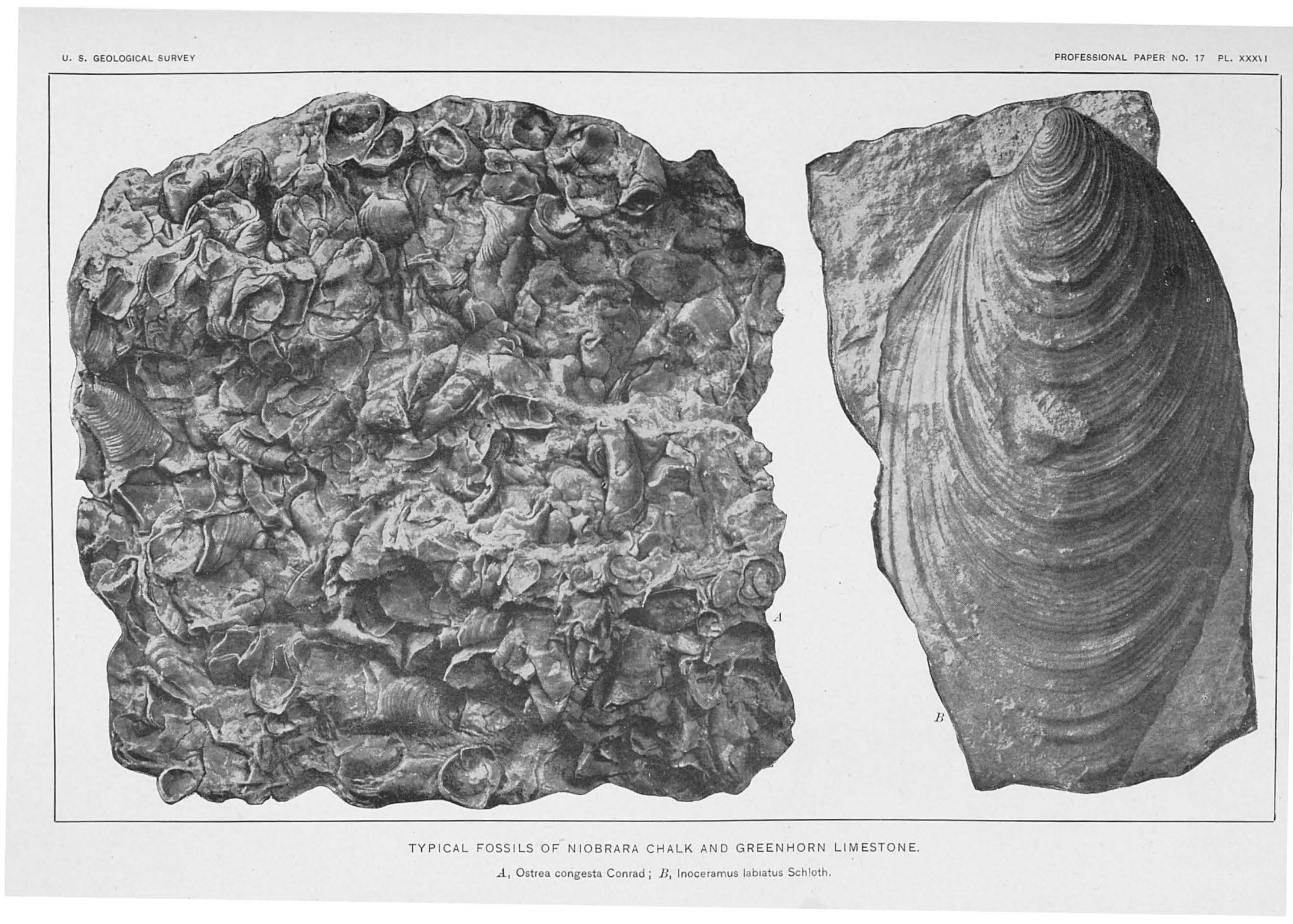






$$
\text { Ala } 10
$$



the outcrop areas east, which will afford some idea of the head to be expected in the intermediate region. In the diagram, fig. 22 , there is shown a piece of physical apparatus which,illustrates the gradient of head between a leak on the one hand and the source of pressure on the other, representing closely the relations which have been found to exist in the South Dakota artesian basin and probably prevail in a measure also in central and eastern Nebraska, where the head of the deeper-seated waters diminishes eastward.

Data are not sufficiently definite as yet for a precise determination of this gradient of head across western Nebraska, but it is apparent that in some of the valleys westward the head is probably higher than the altitude of the land, so that there are prospects for surface flows.

In order to reach the deep-seated waters in western Nebraska it is necessary to penetrate the Tertiary formations, the Pierre clay, the Niobrara limestone, and the Benton shale, to the Dakota sandstone, which should be expected to yield a large

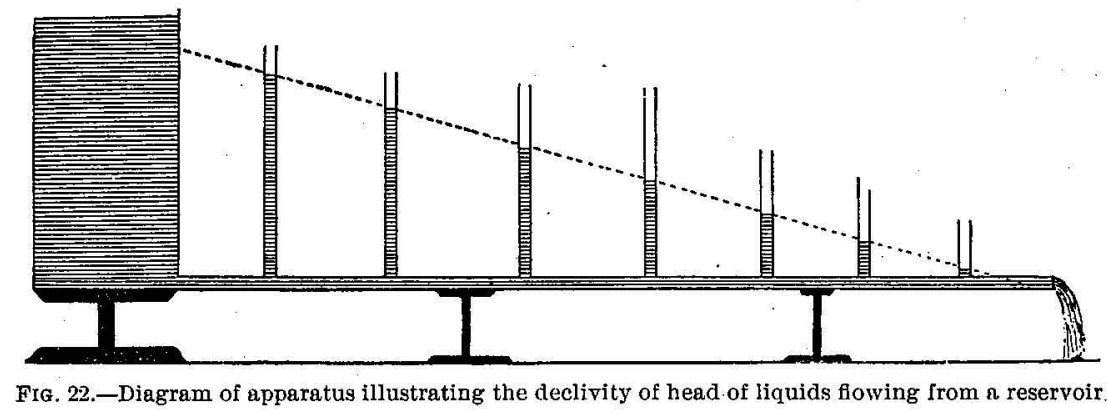

supply of excellent water. An attempt was made to reach this horizon in a deep boring at Chadron some years ago. A depth of 1,100 feet was attained, when the boring was abandoned owing to great difficulty in penetrating the Pierre shale. More recently an attempt has been made at Ardmore by the Burlington and Missouri River Railroad, which attained a depth of 1,500 feet apparently without reaching the bottom of the Upper Cretaceous shales. These shales can be penetrated only by skillful well drillers, and it is necessary to begin with casing 12 or 14 inches in diameter at the top, as the size will have to be reduced occasionally as the boring progresses. The depth to the Dakota sandstone at Crawford will probably prove to be 2,000 feet, and in the valley of North Platte River the amount may be somewhat more. There is possibility of obtaining a flow in these localities, although the altitude is somewhat greater than that of the Dakota sandstone outcrops along the southern margin of the Black Hills. It is to be expected that the pressure of water in the Dakota sandstone will increase to the southwest, in the directiont of the Rocky Mountains. 
Underlying the Dakota sandstone, with a series of gray and red sandstones intervening, are the limestones of Carboniferous age, which contain water in considerable volume and with somewhat greater head than the waters in the Dakota sandstone. These are the same beds as those yielding flows in the Missouri Valley about Omaha, and there is fair reason to believe that they would prove a satisfactory source of water supply in other portions of Nebraska.

\section{SPRINGS.}

Several of the water-bearing formations reach the surface along the valley slopes, where their outcrop is marked by the presence of springs. The locations of the greater number of these springs are shown in Pl. XXXVII. The Arikaree formation in the high area north of the valley of Platte River supplies numerous springs, notably along the northern front of Pine Ridge. The basal beds of the Ogalalla formation also yield springs in the canyons south of the valley of Pumpkinseed Creek and along both sides of the valley of Lodgepole Creek. The most extensive series of springs is along the north front of Pine Ridge, at the base of the Arikaree formation and from the underlying Gering sands. All of the larger canyons contain springs of considerable volume, often at a succession of levels. Sowbelly Canyon is particularly favored in this respect, but the other valleys, from Jim Creek to Chadron Creek, also have good water supplies from these sources. Even on Round Top there is a fine spring just above the top of the Brule clay badlands. In the Brule clay area springs are rare and the volume of water is small. In the underlying Chadron beds there is more or less water at all points, which gives rise to seeps and springs along the outcrop zone of these beds north of Pine Ridge. In the Pierre shale region, next northward, springs are rare, superficial in origin, small in volume, and usually highly mineralized with iron, gypsum, or alkalies.

Along the Niobrara Valley there are occasional springs, mainly in the immediate vicinity of the river. Whistle Creek practically heads in Coyote Springs, at an altitude of 4,520 feet, in the center of T. $27, R .53$. The more important springs along the northern side of the valley of Platte River are East Spring, Spottedtail Spring, Wind Spring, Winter Spring, the springs near the head of Sheep Creek, and those at the headwaters of Red Willow and Indian creeks. They are derived from the lower portions of the Arikaree formation, except the Spottedtail and Winter springs, which emerge from alluvium in valley bottoms.

In the ridge between Platte River and Pumpkinseed Creek there are numerous small springs at the heads of some of the larger canyons which yield excellent water. Their distribution is shown in P.l. XXXVII. The water is derived mainly from the Gering sands at their contact with the Brule clay. 


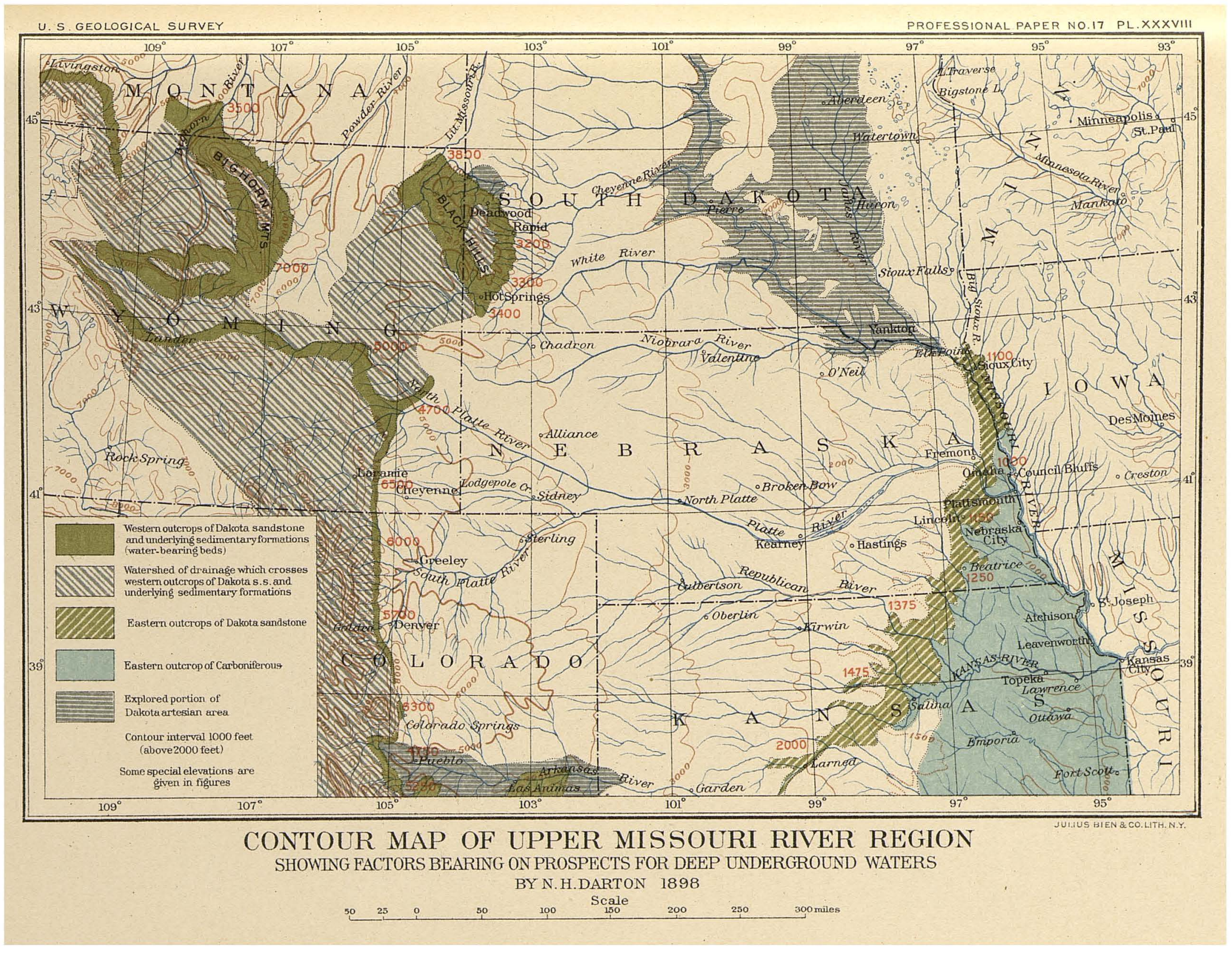



The Pumpkinseed Valley is excavated entirely in the Brule clay, and its lower springs are derived from the alluvial deposits in the valley. This is also the case with springs on Willow Creek and Middle Creek. In the canyons along the north front of the high table-land south of Pumpkinseed Creek there are numerous springs, which yield moderate amounts of water, mainly from the base of the Arikaree formation, and, where this deposit is absent, from the base of the Ogalalla formation. These springs are known as Gabe Spring and Long Spring southwest of Harrisburg and Duggers Spring south of Courthouse Rock.

There are a number of springs along the valley of Lawrence Fork, notably one 2 miles south of Redington, which yields a large flow of excellent water. This flow, however, sinks east of Redington and reaches Pumpkinseed Creek underground.

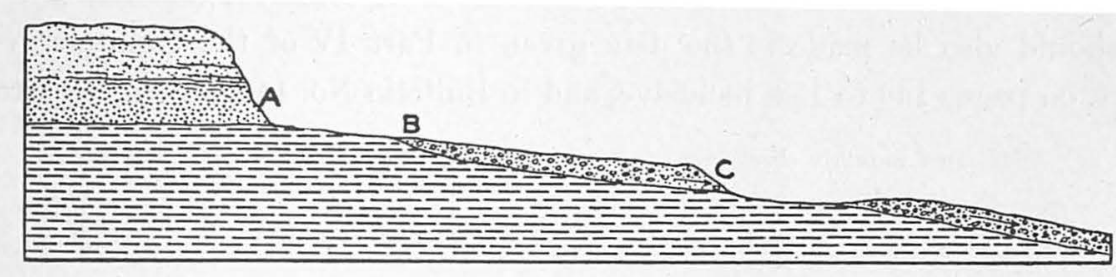

FIG. 23.-Ideal section to illustrate some characteristic features of springs in western Nebraska.

In Lodgepole Valley springs are very rare except at points where the creek itself, having sunk into the alluvial materials in the bottom of the valley, comes out again to flow on the surface for some distance. The best-known spring of this creek is at the "Spring farm," just east of Bronson. Two small springs in Sidney Draw furnish a moderate amount of water.

The springs in this region generally occur under two conditions, which are illustrated in fig. 23. On the left-hand side of the section there is shown the typical spring flowing out of sands, A, at their surface outcrop in a canyon or at the base of high lands. The water gathers from rainfall at a greater or less distance away and sinks underground into permeable beds, through which it travels to emerge as a spring at lower levels. There are many cases, particularly in arid and semiarid regions, where the volume of a rivulet or stream is so small that after running over the surface for some distance the water will sink into the coarse materials which usually lie in the bottom of a valley, as at B. It may then continue as an underflow and emerge in places as a spring of the type shown at $\mathrm{C}$, in the middle of the section in fig. 23. This occurs frequently in the region, and is the nature of some of the low-level springs above described.

14478-No. 17-03-4 
STREAMS.

NORTH PLATTE RIVER.

This stream traverses the central portion of the area and, although it is shallow during the greater portion of the year, carries a relatively large body of water. Its flow is subject to seasonal variations, ranging from a wide, deep torrent in late spring and the first month of summer to a shallow, irregular network of streams flowing among sand bars in the later summer and autumn. It has been estimated that at Gering the North Platte drainage area is 24,340 square miles; at Camp Clarke about 24,830 square miles; and at North Platte 28,517 square miles. The details of river measurements at these three points are given in Water-Supply and Irrigation Paper No. 15 , on pages 84,85 , and 86 , respectively, and the results of computations of discharge on pages 308 to 310 of Part IV of the Nineteenth Annual Report. Reference should also be made to the data given in Part IV of the Eighteenth Annual Report, on pages 153 to 158 , inclusive, and in Bulletin No. 140, on pages 99 to 102.

Estimated monthly discharge of North Platte River at Camp Clarke, Nebraska.

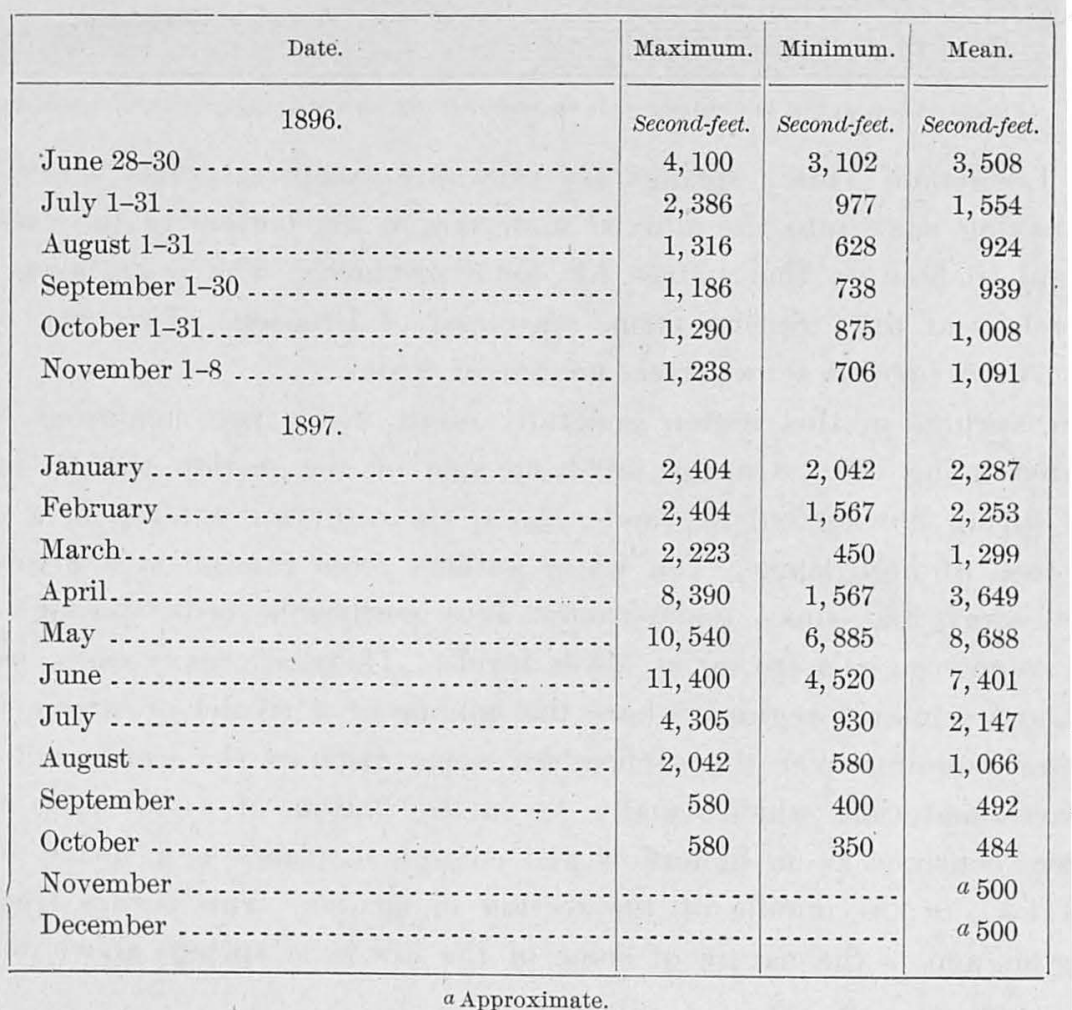

A large volume of the water is taken out of the river at intervals in Scotts Bluff and Cbeyenne counties by the various irrigation canals, so that the reports at 


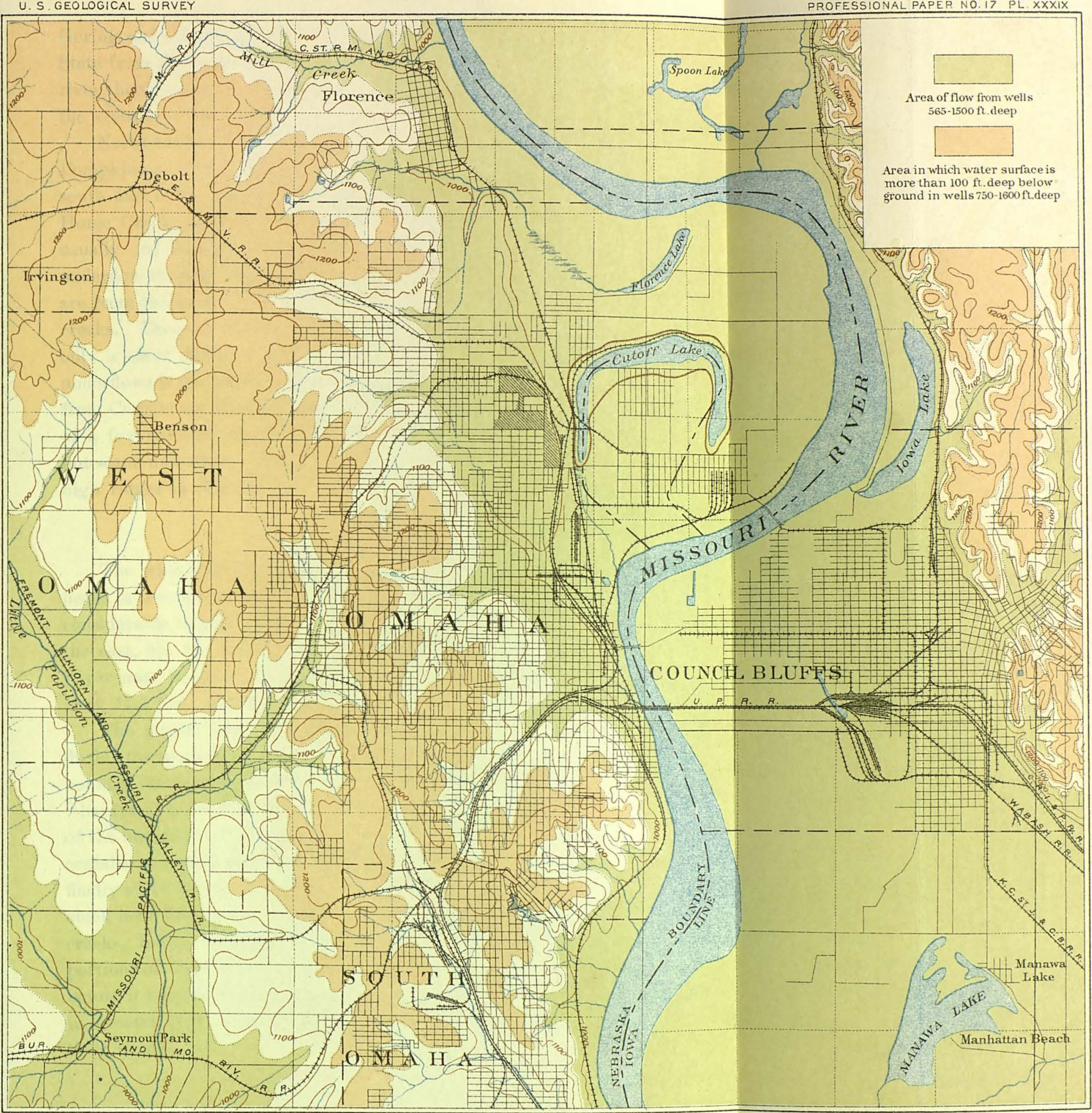

CONTOUR MAP OF OMAHA AND VICINITY SHOWING RELATIONS OF ARTESIAN WATER BY N H.DARTON 189 

Gering and Camp Clarke do not indicate the total volume of water which enters the State from the west. It should be borne in mind also that under the bed of the river there is considerable thickness of coarse sand containing an underflow of which the volume is far greater than that flowing on the surface in dry weather.

North Platte River receives a number of minor branches between the mouth of Pumpkinseed Creek and the Wyoming line. They head in the high ridge to the south and in the edge of the high table-land on the north. With the exception of Horse Creek, their surface waters do not extend to the river, and some of them usually are entirely dry to their heads. There is, however, generally a small underflow through the coarse materials in their beds. The largest volumes of water are from the north, in Dugout, Indian, Red Willow, Winter, Spottedtail, and Sheep creeks. These all head in living springs high up in the canyons, but the waters run only a short distance and sink into the coarse materials, where their volume as underflows is probably not large. Very little water flows out of the ridge extending from Courthouse Rock to the headwaters of Kiowa Creek, and except in the heads of a few canyons where there are springs the valleys are dry and appear to have but scant underflow. Horse Creek carries a moderate volume of water from some high ridges in Wyoming.

PUMPKINSEED CREEK.

The wide valley of Pumpkinseed Creek is traversed by a small stream which heads in the northwest portion of Banner County, in springs and seeps which gather considerable volume in the vicinity of Ashford. Additional supplies are received to the east, but the stream increases in size very gradually. It enters North Platte River near Lapeer. Some gagings made near its mouth were as follows: July 26, 1894, 17.1 feet; June 28, 1896, 22.2 feet.

The stream has numerous branches, but these contribute only surface water during the more rainy portion of the year. They nearly all have underflows of small volume, for their beds consist of gravels and sands into which the water sinks to the "hardpan" floor, and, moving slowly under ground, adds materially to the volume of the underflow of the main creek. The principal affluent is Lawrence Fork, which contains a considerable volume of water in Ts. 17 and $18, R .52$, but this water finally sinks during the summer and flows underground for 2 miles to join the main creek near Redington. The other branches-Greenwood, Hackberry, and Bighorn creeks, Indian Springs, and Willow Creek-all contain some water in the upper portions of their valleys, but this water sinks into the coarse material of the valleys before it reaches Pumpkinseed Creek. The branches from the north are dry coulées in greater part. They contain water from very small springs in the vicinity of their heads. 
LODGEPOLE CREEK.

The waters of Lodgepole Creek rise in Wyoming and, gradually gaining volume, enter Nebraska with a flow which, in August, 1895, was found to be 3.5 cubic feet a second. At about the same time the creek was found to flow 4 cubic feet a second at the north-south line between secs. 34 and .35, T. 15, R. 57 . The volume varies greatly from point to point, but there appears to be a good underflow. For portions of its course the entire volume of the stream is diverted into irrigation ditches. In summer the creek becomes perfectly dry from the vicinity of sec. 28, T. 15, R. 54, for about 12 miles, to a point near the south line of sec. 4 , T. 14, R. 52, where the water again appears, running $2 \frac{1}{4}$ cubic feet a second at first, and then at a dam onehalf mile below 4 cubic feet a second. There are in this vicinity many short ditches which take all or the greater portion of the water and leave the creek dry below the dam in the SE. sec. 14, T. 14, R. 51. It continues dry through sec. 13 and nearly through sec. 19, but near the east line of sec. 19 the water again rises to the surface and flows 2 cubic feet a second for a short distance. Then the creek is dry nearly to sec. 36 , T. 14, R. 50, where there is a flow of about one-half a second-foot, which is diverted into irrigation ditches.

All these measurements were made in August, 1895, by Mr. Adna Dobson, as given in the first report of the State board of irrigation for 1895 and 1896. A measurement of the Lodgepole made at Kimball by Mr. Youngfelt on June 26, 1896, indicated 4.5 second-feet.

Several tributaries empty into the valley of Lodgepole Creek, but they do not contain flowing waters except in times of freshet. The principal one is Sidney Draw with its two branches, heading in the high table-land far westward in Kimball County, south of Lodgepole Valley. The brancies which empty into Lodgepole Creek from the north head in high table-lands a short distance back and descend to the valley as dry coulées with steep declivities. Some contain underflows from springs which ordinarily do not have sufficient volume to reach the surface.

\section{SNAKE CREEK.}

Snake Creek is a stream which beads in the southeast corner of Sioux County, mainly among the sand hills, and flows in a very shallow valley over the table-land north of the valley of North Platte River. It receives waters from various springs, but its flow over the surface is intermittent and the volume of water relatively small. Its principal branch is from the north, known as Point of Rocks Creek, which contains a spring of fair size, but flows mainly underground.

NIOBRARA RIVER.

This stream flows in a relatively shallow depression in the summit of the high table-lands lying between North Platte and White rivers. It enters Nebraska from Wyoming, and is a fine running stream of considerable volume throughout its course. 
For this reason it was called by the Indians Niobrara, meaning "running water." This translation is still much in use, and the French equivalent, "L'eau qui court," is occasionally heard.

We have only two reports on the volume of the river, one of gaging made by Mr. E. T. Youngfelt June 28, 1896, at Marsland, where the flow was found to be 4 second-feet, which seems incredibly small, and the other, a measurement made by Prof. L. E. Hicks in range 51, Dawes County, of 98 second-feet on September 4, 1887.

The principal branch which this stream receives in western Nebraska is Whistle Creek, a flowing stream of small volume which heads in Coyote Springs. The other branches are very small and do not have flowing water at the surface.

WHITE RIVER.

The valley heading in Pine Ridge a short distance east of Harrison and opening diagonally out of the high lands near Crawford contains the headwaters of White River. From its head springs, near Andrews, it is a running stream which gradually increases in volume to the northeast and becomes a prominent river before leaving Nebraska. During the greater part of 1897 a gaging station was maintained at Crawford, Nebr., the results obtained being given on page 299 of Part IV of the Nineteenth Annual Report. The following gagings by Mr. E. T. Youngfelt indicate the volume of White River in early summer and the rate of flow of a number of its branches at various points:

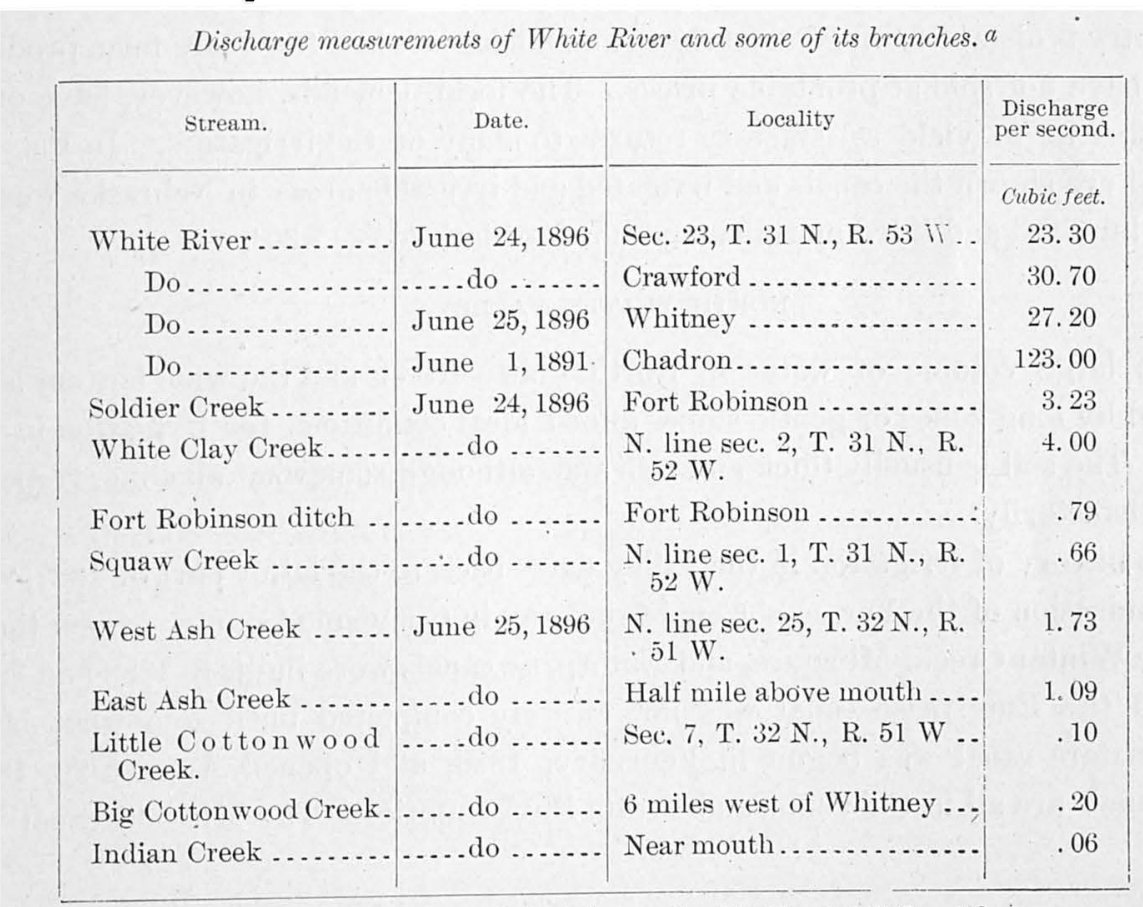

a Eighteenth Ann. Rept. U. S. Geol. Survey (for 1896-97), pt. 4, 1897, p. 193. 
White River receives numerous branches from the deep canyons in the north face of Pine Ridge between Glen station and Chadron, notably from White Clay, A'sh, Indian, and Chadron creeks. Its principal affluent on the north side is Soldier Creek, which heads in T. 32, R. 54, and furnishes a considerable volume of water, in part used in irrigation at Fort Robinson. Little Cottonwood, Big Cottonwood, Lone Tree, and Rush creeks are the principal branches from the north and west. They furnish but small amounts of water and are usually in greater part dry during midsummer.

HAT GREEK BASIN.

Hat Creek and its numerous branches head in deep canyons along the north face of Pine Ridge from Round Top to the Wyoming line. A large amount of water is supplied by the head streams, notably Hat Creek and Sowbelly, Prairie Dog, Monroe, Warbonnet, and Jim creeks, but the amount diminishes rapidly by evaporation as the edge of South Dakota is approached. The branches which head among the low hills north of Pine Ridge contain water only in the rainy portion of the year.

\section{IRRIGATION.}

There is in this region considerable acreage under cultivation with the assistance of irrigation. There are extensive canals along the valley of North Platte River, several ditches along White and Niobrara rivers, and local arrangements for irrigation have been made in some of the smaller valleys. The results have been so satisfactory that there is prospect of some extension of irrigation operations. Much of the country is distant from good markets, and during the last few years farm products usually have not sold at profitable prices. The local demands, however, have often been sufficient to yield satisfactory returns to many of the irrigators. In Pls. XL and XLI are shown the canals and irrigated and irrigable areas in Nebraska west of the one hundred and third meridian and north of latitude $41^{\circ} 30^{\prime}$.

NORTH PLATTE VALLEY.

The large volume of water in North Platte River and the wide bottom lands bordered by long zones of gentle slopes aftord ideal conditions for irrigation in this valley. The soil is usually thick and rich and, although somewhat alkaline, responds most satisfactorily:

The history of irrigation in the valley dates back to the latter part of 1887, with the organization of the Farmers' Canal Company in Cheyenne County. Soon thereafter the Winter Creek, Minatare, and Enterprise canals were built, in 1888 and 1889, although the Enterprise canal was not entirely completed until somewhat later. The Minatare canal was begun in February, 1888, and opened August 20, 1888. These canals are all in Cheyenne and Scotts Bluff counties. The Mitchell canal was 



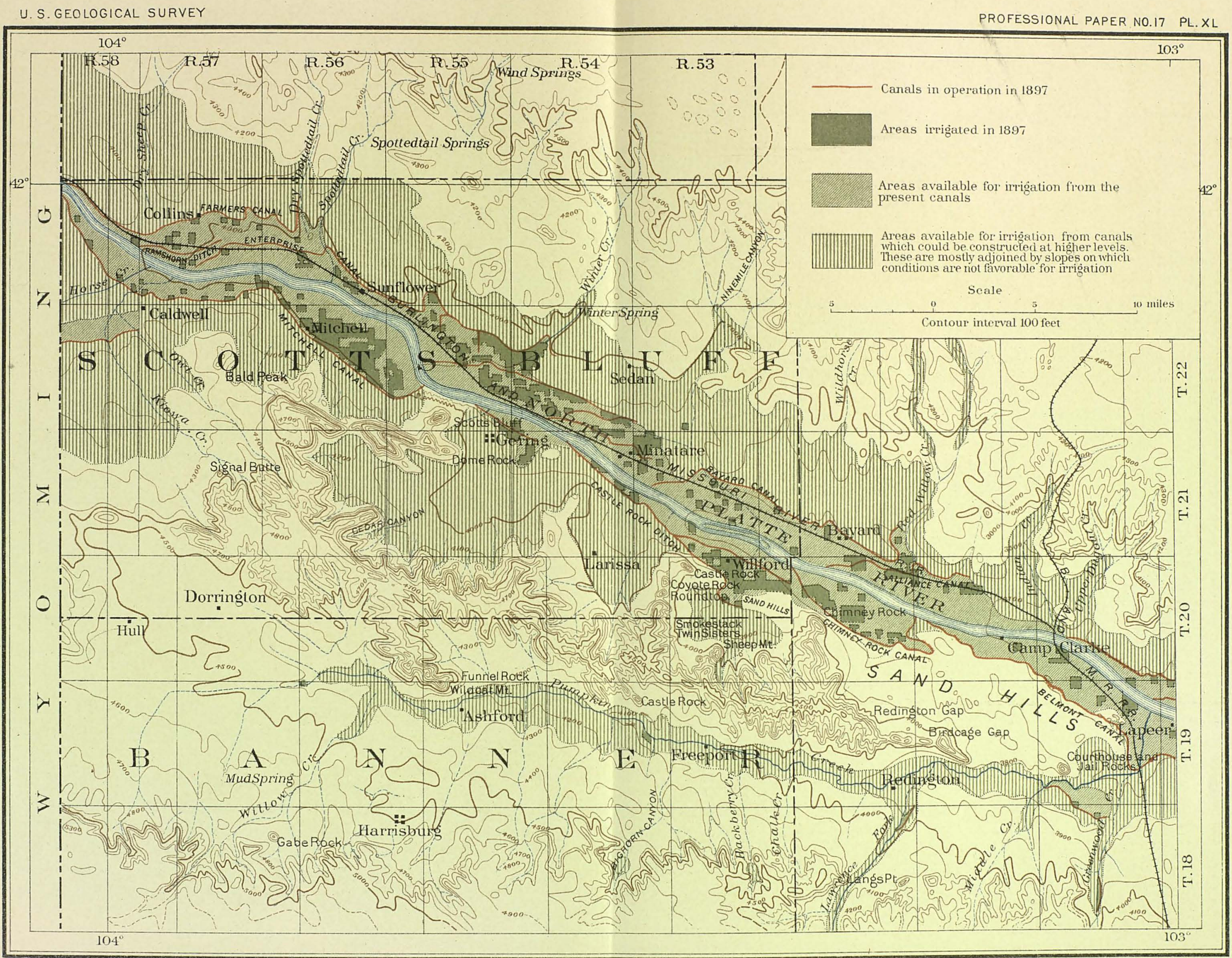

IRRIGATION MAP OF NEBRASKA WEST OF THE 103 D MERIDIAN BY N. H. DARTON 1898 

soon after constructed, in Scotts Bluff County, on the south side of the river west of Scotts Bluff. It is about 25 miles in length, 24 feet wide at the bottom, and conveys water to about 20,000 acres of bottom land. Early in 1888 the Castle Rock canal was constructed. It has a width of 18 feet on the bottom for the first 9 miles and then divides into two branches, each about 8 feet wide on the bottom and carrying 3 feet of water. Another large canal was built at Bayard. In 1893 the Ramshorn ditch was built in the western part of Scotts Bluff County. The Farmers canal has a head gate with a front opening 156 feet wide, with 27 individual gates. It is capable of taking an 8-foot head of water. The canal is 60 feet wide at the bottom and carries 8 feet of water. The first mile is completed 60 feet wide on the bottom, and for the remainder of its length its width is 30 feet. A gaging made at its head gate by Mr. E. T. Youngfelt on June 19, 1896, showed a flow of 2.28 cubic feet a second.

The following list comprises all the main canals, but not the many miles of laterals into which they empty:

List of irrigation canals in valley of North Platte River, in Nebraska, west of the one hundred and third meridian.

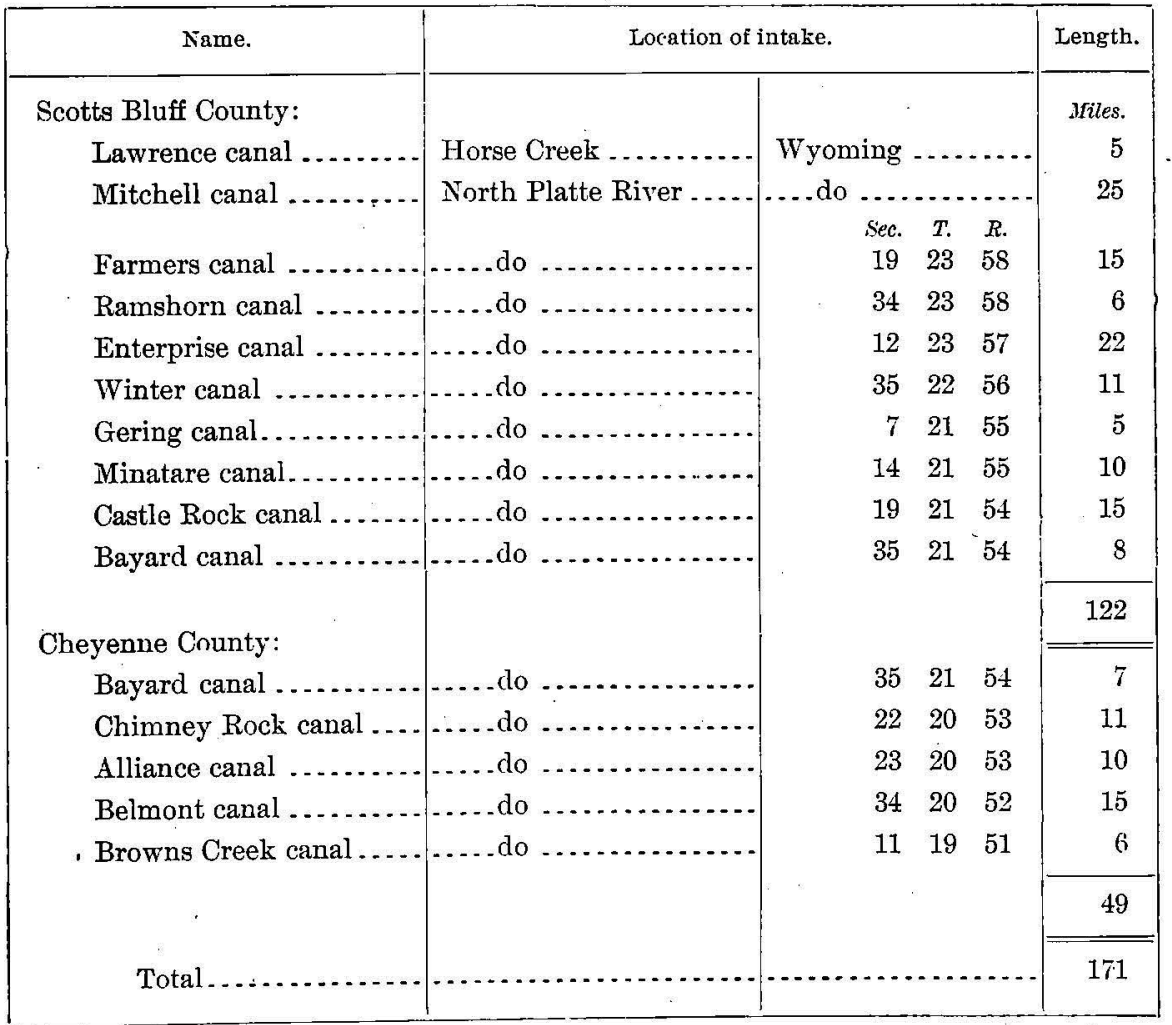


The Lawrence canal derives its water from Horse Creek, in Wyoming, and it is supplemented by one 400-acre storage reservoir 10 feet deep and another covering 180 acres 11 feet deep.

The following estimates of crops raised in the Platte Valley are based on data obtained by Mr. C. A. Fisher and others during the autumn of 1897 . In Scotts Bluff County the area irrigated from North Platte River in 1897 was 16,080 acres, in which wild hay, alfalfa, corn, and wheat were the principal crops. Oats and garden vegetables were also irrigated extensively. In Cheyenne County the area irrigated from North Platte River in 1897 was 4,150 acres, of which hay and alfalfa were the principal products, together with smaller amounts of various cereals and vegetables. The yield per acre of crops under irrigation is somewhat variable. Wheat usually harvests from 30 to 40 bushels an acre; potatoes, 150 to 200 bushels, and wild hay, $1 \frac{1}{2}$ tons. Alfalfa yields 2 tons to the cutting, and is cut three times a season. Near Sunflower post-office there is an extensive orchard under irrigation, which promises to be very successful. It contains about 3,200 trees, many berry bushes, and 5,000 strawberry plants.

The cost of irrigation was found to vary greatly. Figures were obtained for 7,500 acres in the Platte Valley, which indicate an average cost of 41 cents an acre. The farms are mostly from 80 to 160 acres. The individual cost an acre varied in greater part from 30 to 75 cents. In many cases the water was paid for partly in cash and partly in labor.

PUMPKINSEED VALLEY.

Pumpkinseed Creek is available for irrigation of a small marginal acreage along the greater part of its course, but the waters are used only to a small extent. There is a ditch, known as the Courthouse Rock canal, extending from the west line. of range 50 to Greenwood Creek, a distance of 5 miles, and there are several small local ditches and reservoirs at various points, shown in Pl. XL. The area of crops is about 90 acres, embracing several hay meadows. Lawrence Fork is used locally for irrigation 2 miles south of Redington, and its excellent water supply would admit of much more extensive use.

NIOBRARA VALLEY.

The waters of Niobrara River are utilized extensively for the irrigation of narrow strips of the bottom lands. There are canals at frequent intervals along its course, which furnish water mainly for hay meadows. 'Some grain crops are raised, but their acreage is small. The total area under irrigation in 1897 was about 7,015 acres. 



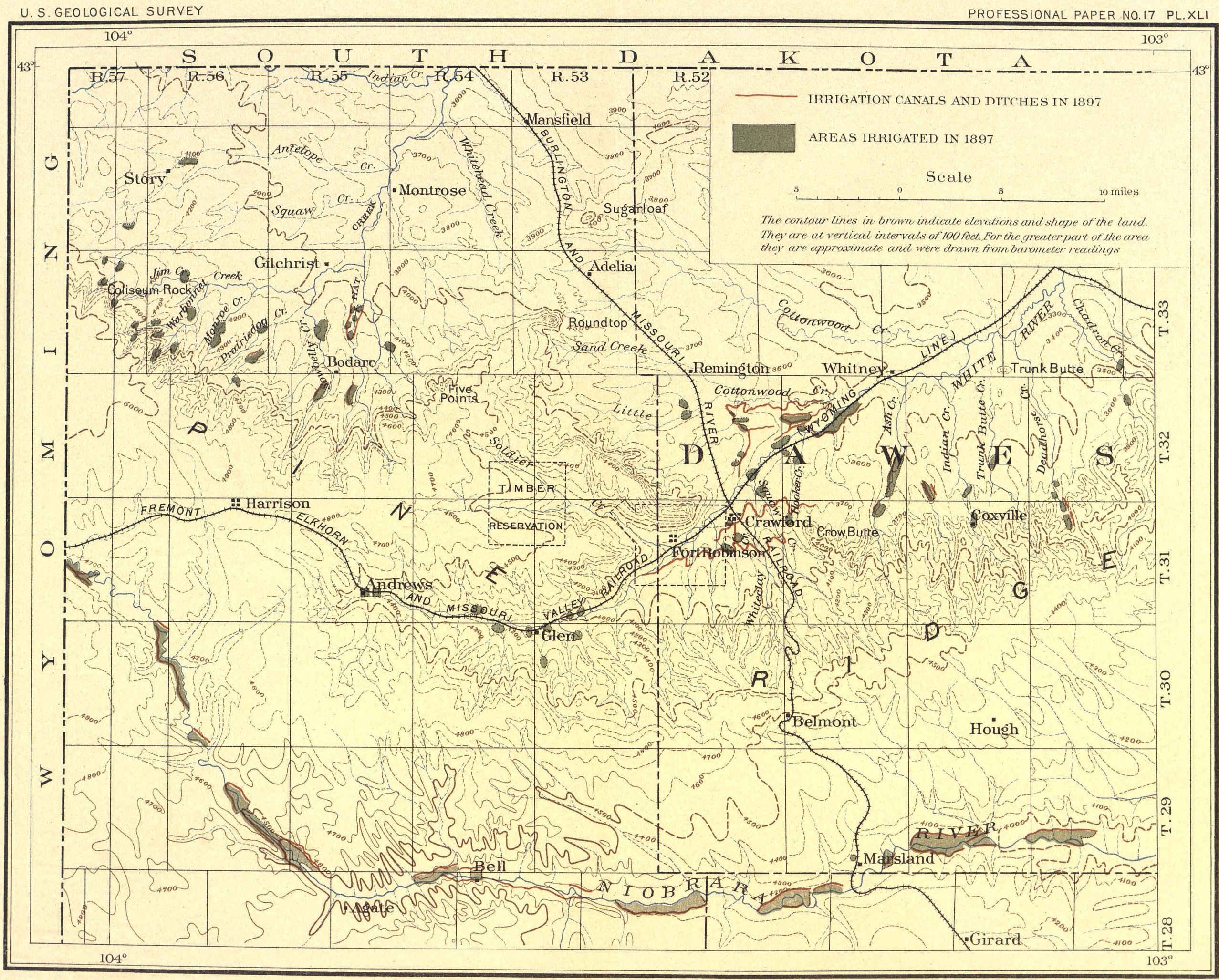

IRRIGATION MAP OF NIOBRARA RIVER,WHITE RIVER,AND HAT CREEK BASINS IN NEBRASKA WEST OF THE 103D MERIDIAN BY N. H.DARTON 1898 

The following is a list of the canals, compiled from data recently obtained by the State engineer:

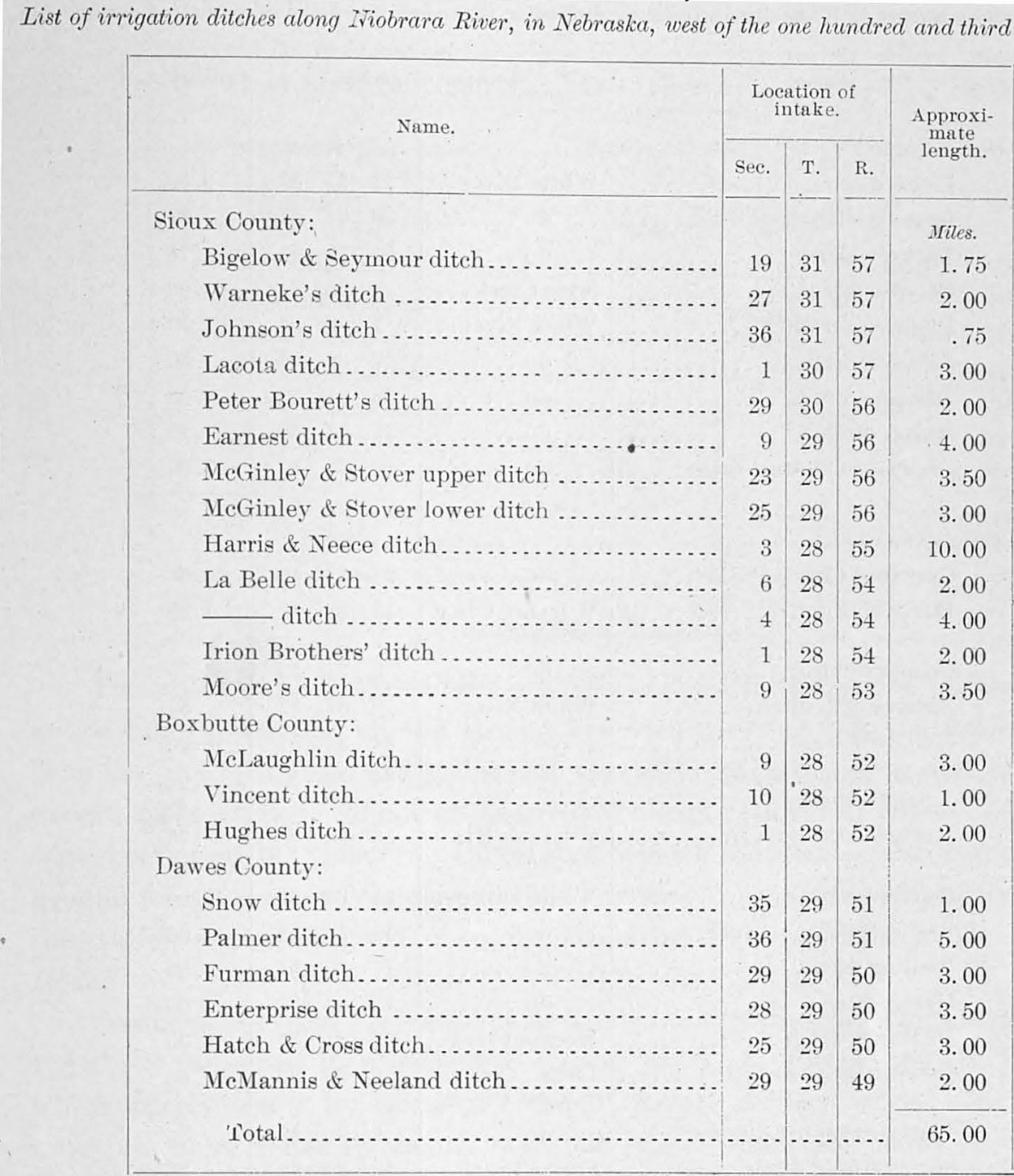

WHITE RIVER BASIN.

The relatively large volumes of running water in White River and those of its branches which head in the canyons on the north front of Pine Ridge have been utlized at various points for irrigation. Many ditches have been constructed, and there are plans for a more extensive use of the waters. At present about 3,655 acres are under irrigation, in greater part along the main valley. 
The following list of ditches is compiled from data obtained by the State engineer during 1897:

List of irrigation ditches in White River Basin, in Nebraska, west of the one hundred and third meridian.

\begin{tabular}{|c|c|c|c|c|c|}
\hline Name. & \multicolumn{4}{|c|}{ Location of intake. } & Length. \\
\hline Sioux County: & & Sec. & $T$. & $R$. & Miles. \\
\hline Lewis ditch............... & White River... & 27 & 31 & 55 & 0.50 \\
\hline Schwartz-Hughson ditch..... & ..... do .. & 26 & 31 & 55 & .25 \\
\hline Tucker's ditch . & ..... do ....... & 34 & 31 & 54 & .75 \\
\hline Colville ditch ....... & Kyle Creek .... & 3 & 30 & 54 & 1.00 \\
\hline Diedrichson ditch .. & White River ... & 1 & 30 & 54 & .50 \\
\hline Johnson diteh ..... & .... do .. & 7 & 30 & 53 & .50 \\
\hline Jacobson ditch....... & ..... do .. & 32 & 31 & 53 & .50 \\
\hline Mason ditch ......... & .... do ....... & 32 & 31 & 53 & .25 \\
\hline Crawford Citizens' ditch.. & ..... do .. & 23 & 31 & 53 & 1.50 \\
\hline Dawes County: & & & & & 5.75 \\
\hline Crawford Citizens' ditch... & .... do ........ & 23 & 31 & 53 & 18.50 \\
\hline Hazleton ditch...... & $\begin{array}{l}\text { White Clay } \\
\text { Creek. }\end{array}$ & 13 & 31 & 52 & 1.00 \\
\hline Cooper ditch....... & .... do ....... & 2 & 31 & 52 & 1. 75 \\
\hline Butterworth ditch... & White River... & 3 & 31 & 52 & .50 \\
\hline Hall's ditch . . . . . . . . . . . . & ..... do .. & 34 & 32 & 51 & 13.00 \\
\hline $\begin{array}{l}\text { White River Irrigation Com- } \\
\text { pany's ditch. }\end{array}$ & ..... do ... & 34 & 32 & 52 & 2.00 \\
\hline MeFarland's ditch........... & $\begin{array}{l}\text { White Clay } \\
\text { Creek. }\end{array}$ & 35 & 32 & 52 & .75 \\
\hline Harris \& Cooper ditch... & White River... & 25 & 32 & 52 & 10.00 \\
\hline Rasher ditch...... & ..... do .. & 19 & 32 & 51 & 1.00 \\
\hline Welling ditch..... & ..... do .. & 17 & 32 & 51 & .50 \\
\hline Harris diteh ...... & .... do ....... & 17 & 32 & 51 & 2.00 \\
\hline MeManus ditch ........ & Hooker Creek . - & 7 & 31 & 51 & 1.00 \\
\hline Stewart Brothers' ditch.. & $\begin{array}{l}\text { Little Cotton- } \\
\text { wood Creek. }\end{array}$ & 8 & 32 & 52 & 1.50 \\
\hline Thomas Stewart ditch ... & ..... do .. & 8 & 32 & 52 & .75 \\
\hline Spring Creek ditch . ......... & Spring Creek... & 13 & 32 & 52 & .75 \\
\hline Spring Creek ditch No. 1 .... & .... do ....... & 18 & 32 & 51 & 1. 00 \\
\hline Kusil ditch ............ & $\begin{array}{l}\text { Little Cotton- } \\
\text { wood Creek. }\end{array}$ & 9 & 32 & 51 & 1.00 \\
\hline Mace ditch . . . . . . . . . . . . & WestAshCreek. & 2 & 31 & 51 & 1.00 \\
\hline $\begin{array}{l}\text { West Ash Creek Irrigation } \\
\text { Company's ditch. }\end{array}$ & ..... do .. & 36 & 32 & 51 & 2.00 \\
\hline Baron diteh ......... & East Ash Creek. & 32 & 32 & 50 & .50 \\
\hline Ox Yoke ditch........ & .... do ....... & 31 & 32 & 50 & 1.50 \\
\hline James Wilson ditch .... & Indian Creek .. & 10 & 31 & 50 & .125 \\
\hline Seegrist ditch .......... & .... do ........ & 3 & 31 & 50 & .50 \\
\hline
\end{tabular}


List of irrigation ditche's in White River Basin, in Nebraska, etc.-Continued.

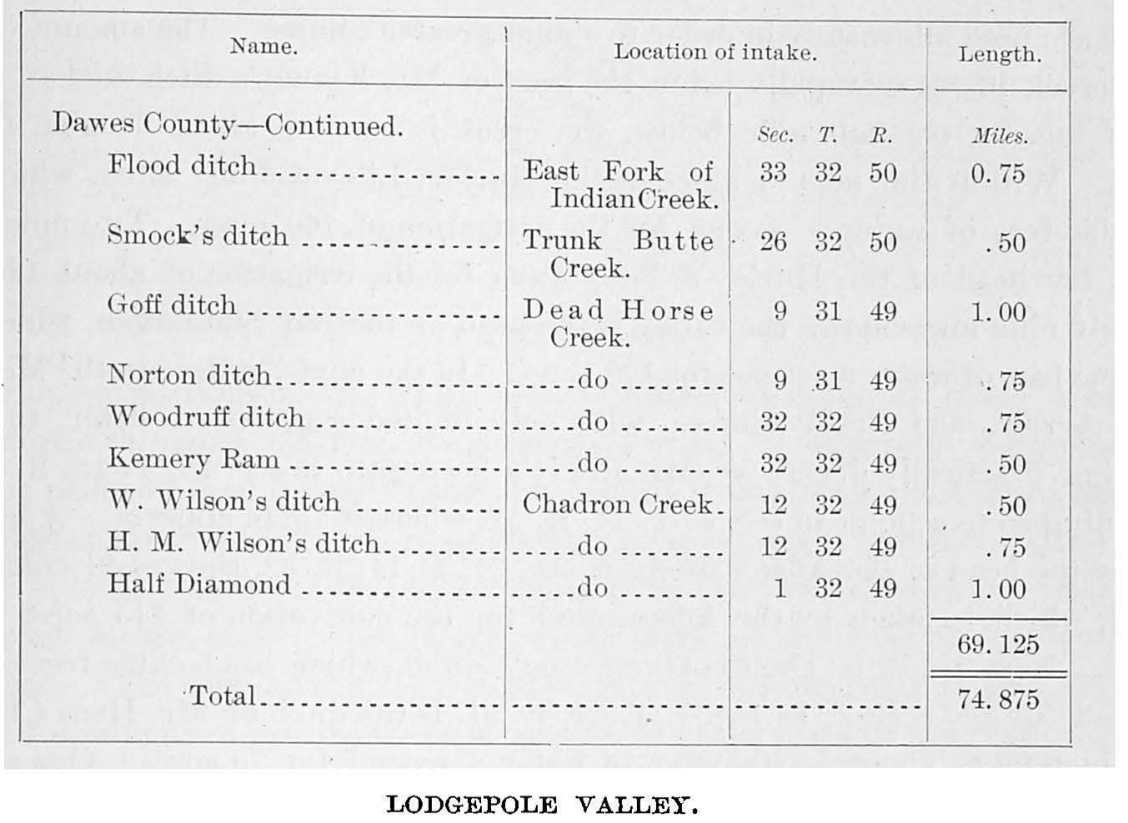

The water of Lodgepole Creek has been utilized for irrigation for several years, and at times practically all the stream has been diverted into the fields. Hay has been the principal crop, but grains and vegetables have also been irrigated to some extent. The average volume of the creek is about 4 cubic feet per second, but along some portion of the valley the waters sink beneath the surface and, traveling underground for some distance, emerge again in springs. The following facts relating to this valley are taken from notes by Mr. Adna Dobson, made in the summer of 1895: ${ }^{a}$

Commencing from the west, the first ditch is the Hoover, which supplies water for about 50 acres; then come the ditches of S. A. Pierce and L. C. Kinney, which supply water for about 575 acres, mainly of hay lands. In the next 4 miles no more water is taken out, and then comes the head of the Young ditch, which supplies water for about 30 acres, extending to sec. 34, T. 15, R. 57 . Five miles lower down is the ditch of Carl Ruttner, which takes water on each side of the creek, the total amount being 4.9 cubic feet a second, which is used for covering about 40 acres. One mile lower down is the beginning 'of J. J. Kinney's south ditch, which takes all the water in the creek, $3 . \dot{6}$ cubic feet a second, for the cultivation of about 140 acres. One-half mile below this is the head of J. J. Kinney's north ditch, into which the entire creek is diverted. The

a First Biennial Report of the State Board of Irrigation of the State of Nebraska for 1895 and 1896, prepared by W. R. Akers, Lincoln, 1897, pp. 151-157. 
amount of water is 2.1 cubic feet a second for the watering of 190 acres. These ditches are used alternately in order to obtain greater volume. The amount of water in the creek increases rapidly below the head of Mr. Kinney's ditch, and at the east line of sec. 34, one-half mile below, the creek is running about 6 cubic feet per second. Within the next 3 miles is the Hurley, Liley \& Polly ditch, which takes 4.5 cubic feet of water a second for the irrigation of 160 acres. Two miles below this is the head of the Hurley \& Polly ditch for the irrigation of about 125 acres. One-half mile lower down the valley is the head of the Bay State ditch, which takes 2.5 cubic feet of water a second for 100 acres. In the next 7 miles are the McIntosh, Circle Arrow, and Brady ditches, with only limited supplies of water, the creek becoming practically dry above. Mr. Brady's head gate in sec. 28 , T. 15, R. 54, and continuing so to a point in sec. 4, T. 14, R. 52, where it again appears. A measurement at the head of the Adams diteh, in sec. 31, T. 14, R. 52, showed $2 \frac{1}{4}$ cubic feet a second, which is taken by the Adams ditch for the cultivation of 245 acres, mainly of hay. Next below is Thomas Gunderson's ditch, which has 5 cubic feet of water a second for 100 acres. In sec. 7, T. 14, R. 51, is the ditch of Mr. Hans Christianson, which takes about 1 cubic foot of water a second for 70 acres. One and onehalf miles below this is the ditch of Mr. James Mitchell, which takes 3.5 cubic feet a second for 60 acres; and next below is the bead of Mr. John Anderson's ditch, for 200 acres. This ditch is used alternately with the Mitchell ditch in order to have a sufficient volume of water. Then comes the very small ditch of Mr. J. A. Shanahan for the irrigation of 2 or 3 acres. The next dam below is for Mr. M. Urback's ditch. Then there is the ditch of N. P. Lingholm, which heads in the SE: $\frac{1}{4}$ sec. 14, T. 14, R. 51 , and provides water for 30 acres. It was taking 1.5 cubic feet of water a second at the time of observation. The creek is dry below this through sec. 13 and nearly through sec. 19. Near the east line of sec: 19 the water rises again, and at the head of the Couch ditches, in the SW. $\frac{1}{4}$ sec. 20, T. 14, R. 50, 2 cubic feet a second is available for the irrigation of about 40 acres. Runge's ditches, Nos. 1 and 2, are in secs. 28 and 29, T. 14, R. 50, and provide for about 105 acres. The Ickes ditch comes next, but the amount of water is hardly sufficient to cover more than 100 acres. About one-half cubic foot of water a second passes the Ickes dam and fills a small pond at the head of the Adams \& Tobin ditch, but the supply was inadequate to cover the 180 acres to be irrigated. Below this dam the creek is entirely dry for the next mile, where the water rises again in springs; and at the head of the Trognitz ditch, in sec. 36, T. 14, R. 50, one-half a cubic foot of water a second flows into the ditch and is used for the irrigation of about 34 acres. It is the same ditch that was built by the United States to supply water for Fort Sidney.

The table following gives the acreage of crops irrigated in the Lodgepole Valley west of the one hundred and third meridian in 1896, according to the first report of the State board of irrigation (p. 158). 
IRRIG ATION.

Acreage of.crops irrigated in the Lodgepole Valley west of the one hundred and third meridian in 1896.

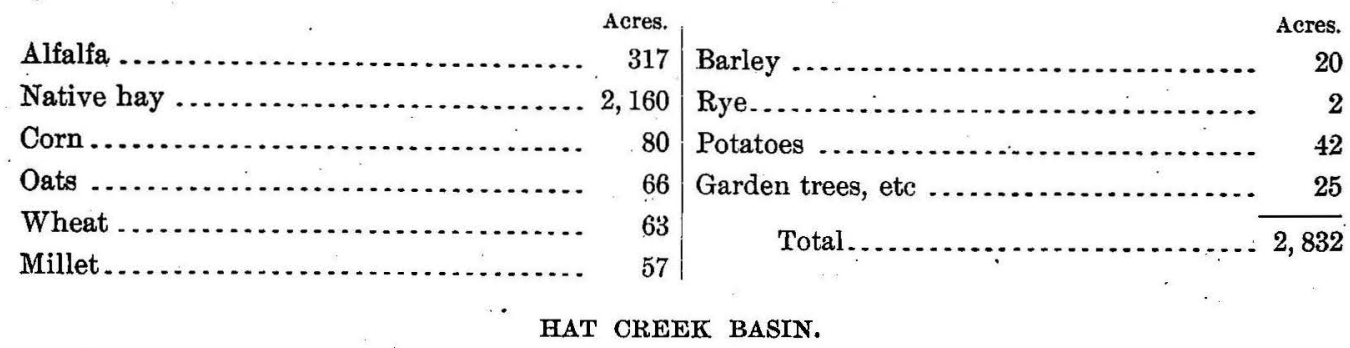

The upper portions of Hat Creek and its numerous branches rising in canyons in the northern slopes of Pine Ridge contain water in sufficient supply for the irrigation of many local areas. These are mainly in the relatively narrow canyons, where only small strips of land are so situated as to be easily watered. The volume of water in most cases is ample and is derived from ever-flowing springs. Nearly all the canyons contain small, short canals, which serve for the irrigation of numerous small farms. The total area under irrigation in 1897 was estimated to be 1,860 acres.

The following is a list of the canals according to the plots of the State engineer:

\begin{tabular}{|c|c|c|c|c|c|}
\hline Name. & Location of in & take. & & & Length. \\
\hline & & Sec. & $T$. & $R$. & Miles. \\
\hline Steel ditch.. & Hat Creek....... & 16 & 32 & 55 & 1.50 \\
\hline Coffee's ditch ... & ..... do .............. & 26 & 33 & 55 & 5. 00 \\
\hline Miller ditch ... & ... do ............ & 23 & 33 & 55 & .75 \\
\hline Holly's ditch .. & Boggy Creek........ & 31 & 33 & 54 & 1.00 \\
\hline Old Sowbelly ditch. & Sowbelly Creek .... & 7 & 32 & 55 & 2.00 \\
\hline Hall's ditch ... & .... do ............ & 6 & 32 & 55 & .50 \\
\hline M. D. Jordan's ditch.. & .... do ............. & 21 & 33 & 55 & 1.50 \\
\hline Schlitz ditch... & Cedar Creek ....... & 35 & 33 & 56 & 2. 00 \\
\hline Valdeg ditch.... & Prairie Dog Creek.. & 3 & 32 & 56 & .50 \\
\hline Zerbst ditch ..... & .... do ........... & 25 & 33 & 56 & 1.00 \\
\hline Big Monroe Creek diteh . & Big Monroe Creek & 33 & 33 & 56 & 2. 00 \\
\hline Biehle ditch ....................... & 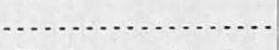 & 32 & 33 & 56 & .75 \\
\hline Nolan's ditches, No. 1 and No. 2. & Warbonnet Creek . & 23 & 33 & 57 & 1.25 \\
\hline Kay's ditch....... & ..... do ...... & 26 & 33 & 57 & .75 \\
\hline Daut ditch..... & ..... do ...... & 30 & 33 & 56 & 1.00 \\
\hline$\longrightarrow \operatorname{ditch} \ldots . .$. & .... do ...... & 31 & 33 & 56 & 1.00 \\
\hline Warbonnet ditch... & ..... do ...... & 21 & 33 & 56 & 1.50 \\
\hline Woodruff's ditch... & Jim Creek.......... & 14 & 33 & 57 & 1.00 \\
\hline Slattery's ditch .... & ..... do .............. & 13 & 33 & 57 & 1.00 \\
\hline Jim 'Creek ditch .............. & ..... do ....... & 8 & 33 & 56 & .50 \\
\hline Hamlin ditch .................. & Squaw Creek & 10 & 33 & 57 & .50 \\
\hline Dumn's ditch ...... & ..... do ............... & 11 & 33 & 57 & 2.00 \\
\hline
\end{tabular}




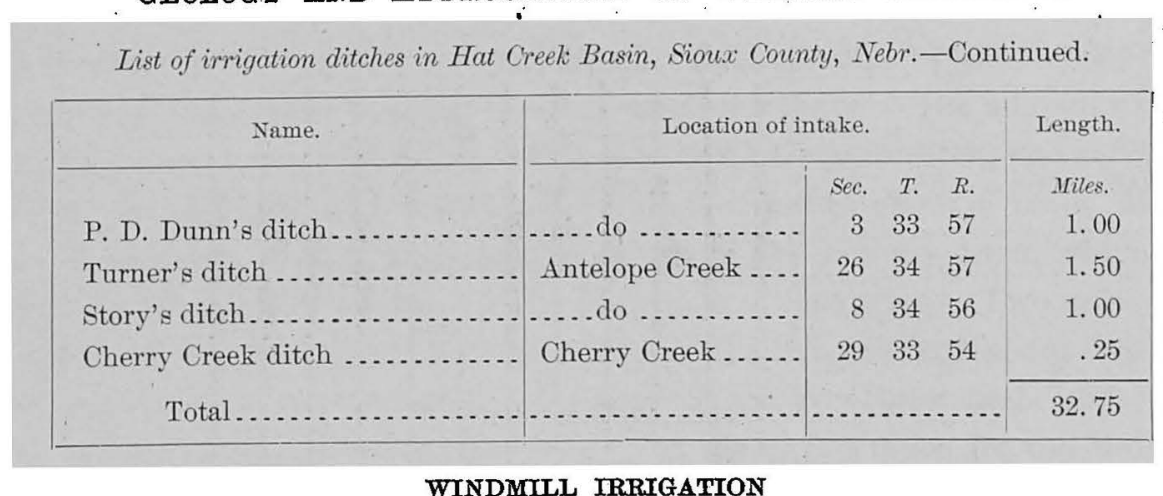

Several farmers in western Nebraska have experimented with windmill irrigation with encouraging results. There are large supplies of underground waters under the high table-lands, beginning with Pine Ridge and lying in broad expanse between the larger valleys. This is notably the case on the fine table lying between the valleys of Lodgepole Creek and Pumpkinseed Creek. These waters are usually at. a depth of over 175 feet, but a large windmill soon raises sufficient water to fill a fairsized reservoir. About 10 acres seems to be the limit for irrigation from one windmill, but this area will afford sufficient crops for local use. A reservoir is essential for satisfactory irrigation from a pump, but there usually is no difficulty in constructing one in the table-land areas.

\section{CLIMATE.}

Western Nebraska has a climate of typical plains character. It is dry and hot in summer, moderately moist in late spring, and cold, but with little snow, in winter. There is considerable variability in the climatic features from year to year, rather more than is found farther south or north, and some local variations from point to point, particularly in rainfall. Recoris of weather were kept for many years at Sidney, in the.Lodgepole Valley, and at Fort Robinson, on White River, while for shorter periods observations have been made at Alliance, Gering, Hay- Springs, Kimball, and Camp Sheridan. In Pl. XLII there is given a graphic reproduction of rainfall records covering a period of several years at some of the stations asove mentioned, compiled from an article on the Rainfall of Nebraska, ${ }^{a}$ by C. D. Swezey and G. A. Loveland, together with data for 1896 and 1897, kindly supplied by Mr. Loveland.

\section{TIMBBER.}

The occurrence of timber in this region is restricted to certain localities of relatively limited extent. In the greater part of the plains area there is no timber at all, and the valleys of the Platte and upper Niobrara rivers and Lodgepole Creek do not contain trees. Along the northern escarpment of Pine Ridge, on the slopes of the White River and Hat Creek basins, there is a moderately wide zone of scattered 


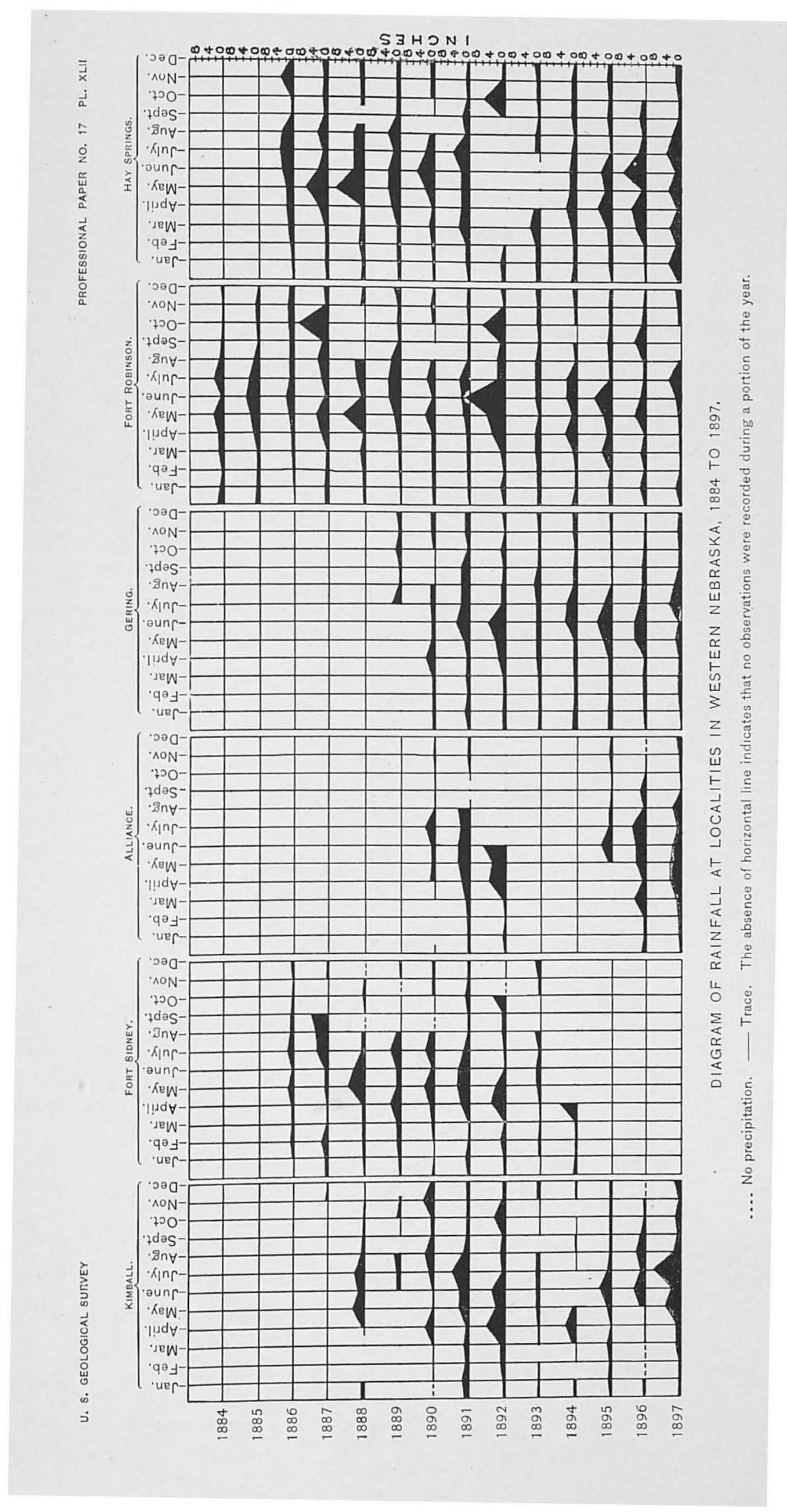



pine forest. It extends from the crest of the ridge down nearly to the foot of the steeper slopes, and the aggregate amount of timber is fairly large. Along the ridge south of North Platte River there was formerly considerable pine, and many of the slopes north of Platte River and south of Pumpkinseed Valley maintained a scattered growth of pine. Some of the canyons in this region contain deciduous trees in small groves, and this is also the case in the many canyons in the northern slopes of Pine Ridge and at intervals along the banks of White River. The extent of the timber in this region is shown in PI. XLUI. The principal tree is the Rocky Mountain pine (Pinus ponderosa). It attains a diameter of from 1 to 2 feet where the conditions are most favorable; but its growth is somewhat scattering, and deep inroads have been made on the supply by woodcutters. The young pines appear to be thrifty, as they spring up abundantly on most of the slopes, and are growing vigorously. Some features of the pine growth are shown in Pls. VIII and XXI.

In the region adjoining North Platte River the growth of pines is rather scanty, and nearly all of the larger trees have been or are being cut. This is also the case along the edge of the table-land south of Pumpkinseed Creek.

The deciduous trees of the region comprise mainly cottonwood (Populus monilifera), with a moderate proportion of box elder (Negundium americanum), and a small variety of other similar trees.

ELEVATIONS.

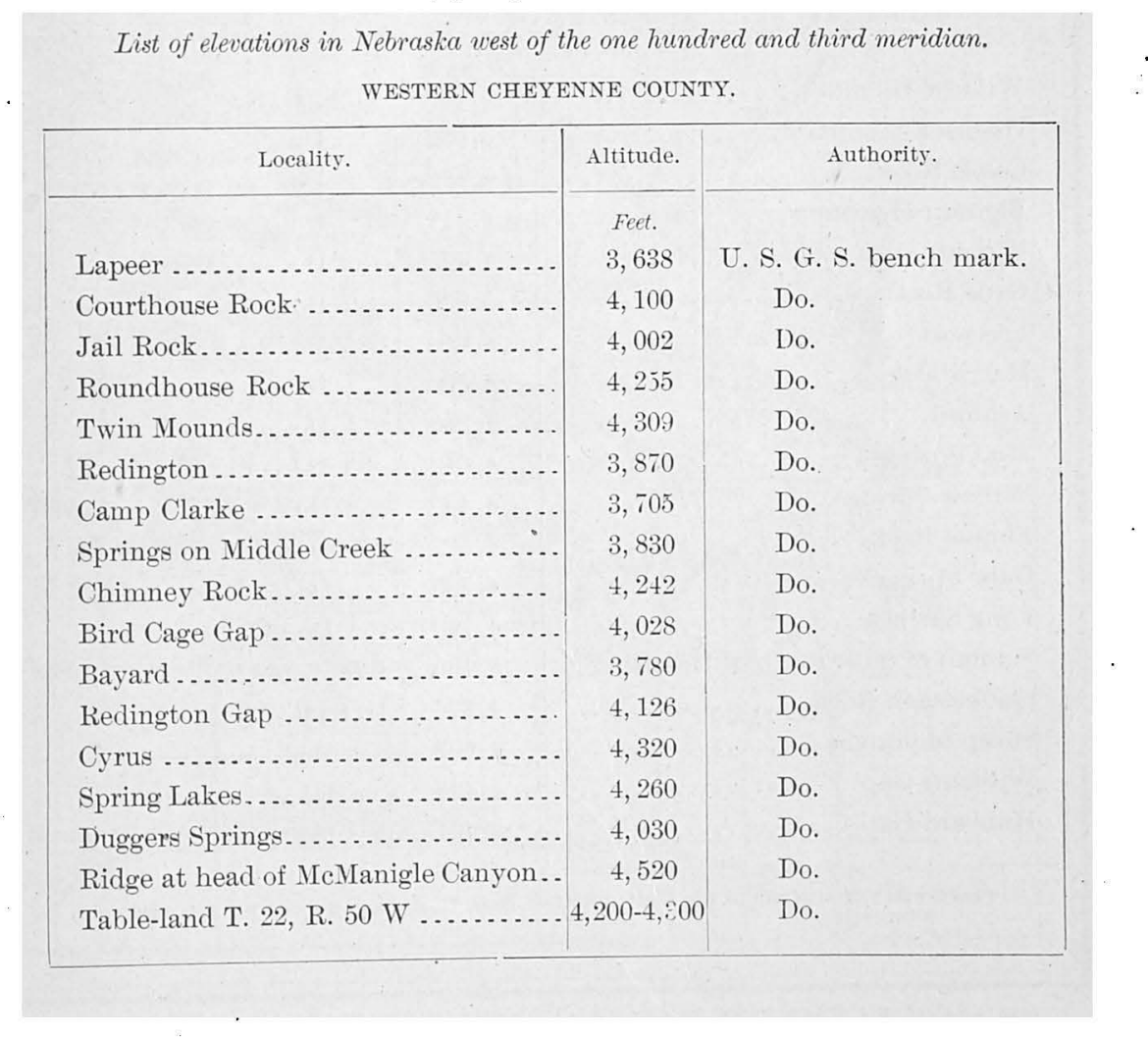


List of elevations in Nebraska vest of the one hundred and third meridian-Continued. WESTERN CHEYENNE COUNTY-Continued.

\begin{tabular}{|c|c|c|}
\hline Locality. & Altitude. & Authority. \\
\hline Ickes post-office... & $\begin{array}{l}\text { Feet. } \\
4,415\end{array}$ & Barometer. \\
\hline Table at head of Wild Horse Canyon.. & 4,450 & U. S. G. S. \\
\hline Sidney ............ & 4,090 & Gannett. $a$ \\
\hline Margate siding ........ & 4,138 & Union Pacific Railroad. \\
\hline Bronson .......... & 4,203 & Do. \\
\hline Herdon siding ..... & 4,301 & Do. \\
\hline Potter........... & 4,377 & Gannett. $a$ \\
\hline Jacinto siding....... & 4,486 & Union Pacific Railroad. \\
\hline
\end{tabular}

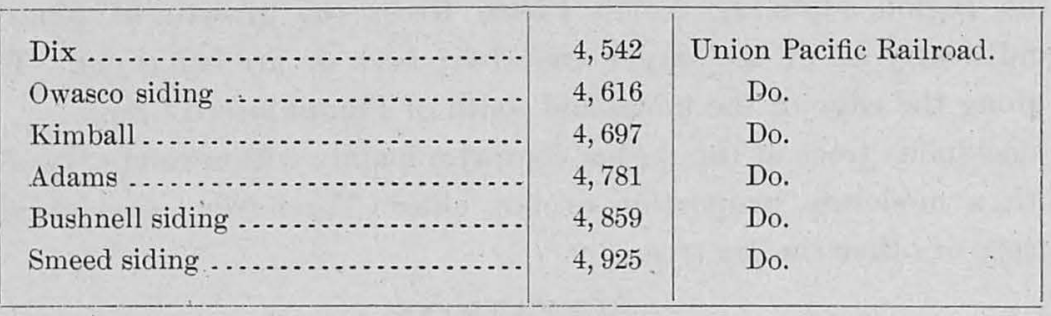

BANNER COUNTY.

\begin{tabular}{|c|c|c|}
\hline Wildeat Mountain. & 5,038 & U. S. G. S. \\
\hline Hogback Mountain... & 5,082 & Do. \\
\hline Castle Rock. . & 4,472 & Do. \\
\hline Bighorn Mountain ......... & 4,718 & Do. \\
\hline Wrights Gap..... & 4,425 & Do. \\
\hline Gabe Rock ...... & 5,006 & Do. \\
\hline Freeport........... & 4,010 & Do. \\
\hline Harrisburg .... & 4,500 & Do. \\
\hline Ashford .......... & 4,230 & Do. \\
\hline Mud Springs....... & 4,640 & Do. \\
\hline Willow Springs ..... & 4,450 & Do. \\
\hline Funnel Rock...... & 4,502 & Do. \\
\hline Gabe Springs ...... & 4,700 & Do. \\
\hline Long Springs ....... & 4,700 & Do. \\
\hline Summit of table south of Harrisburg. & 5,100 & Barometer. \\
\hline Smokestack Rock ................. & 4,326 & U. S. G. S. \\
\hline Sheep Mountain .............. & 4,507 & Do. \\
\hline Williams Gap................. & 4,420 & Do. \\
\hline Hubbard Gap.................. & 4,494 & Do. \\
\hline
\end{tabular}

$a$ Dictionary of altitude in the United States: Bull. U. S. Geol. Survey No. 160, 1899. 


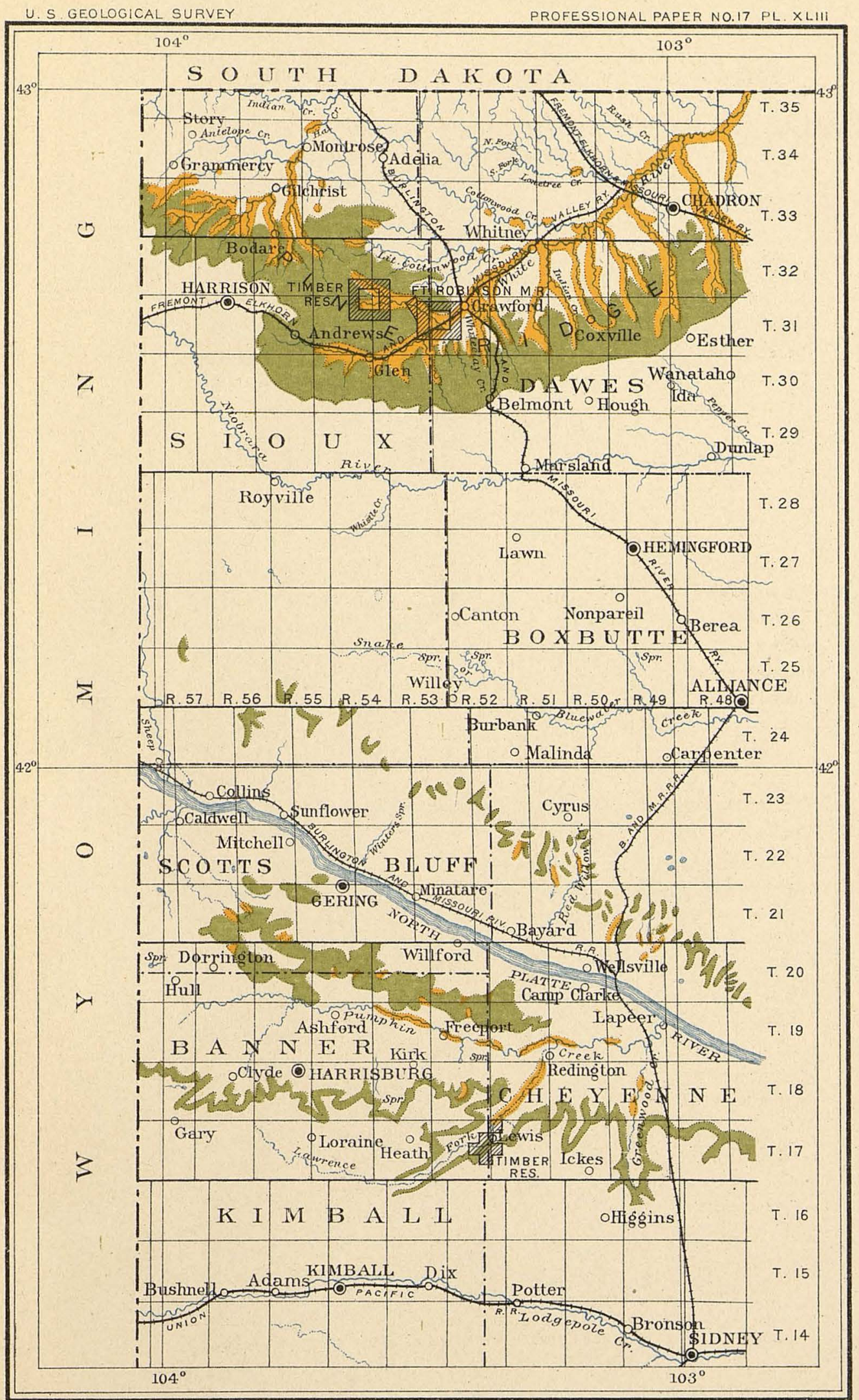

MAP SHOWING DISTRIBUTION OF TIMBER IN WESTERN NEBRASKA BY N.H.DARTON

$$
\text { Scale of miles } 20 \quad 30
$$

DINE TIMBER $\square$ COTTONWOOD, BOXELDER,AND OTHER DECIDUOUS TIMBER 

List of elevations in Nebraska west of the one hundred and third meridian-Continued. SCOTTS BLUFF COUNTY.

\begin{tabular}{|c|c|c|}
\hline Locality. & Altitude. & Authority. \\
\hline & Feet. & \\
\hline Scotts Bluff ......... & 4,662 & U.S. G. S. \\
\hline Dome Rock...... & 4,560 & Do. \\
\hline Gering ............ & 3,902 & Do. \\
\hline Sedan ............. & 3,965 & Do. \\
\hline Winter Springs ..... & 3,990 & Do. \\
\hline Minatare ............ & 3,825 & Do. \\
\hline Sunflower .......... & 3,940 & Do. \\
\hline Collins ............ & 4,018 & Do. \\
\hline Caldwell. ........... & 4,050 & Do. \\
\hline Mitchell .............. & 4,000 & Do. \\
\hline Larissa . . . . . . . . . . & 3,960 & Do. \\
\hline 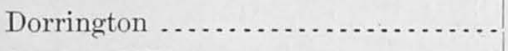 & 4,450 & Do. \\
\hline Intake of Winter canal ............ & 3,900 & Do. \\
\hline Intake of Enterprise canal .......... & 3,980 & Do. \\
\hline Roubedeau Pass........ & 4,480 & Do. \\
\hline 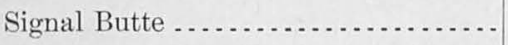 & 4,583 & Do. \\
\hline $\begin{array}{l}\text { Summit of Ridge at head of Cedar } \\
\text { Canyon. }\end{array}$ & 4,860 & Do. \\
\hline Mitchell Pass . . . . . . . . . . . . . . . & 4,180 & Do. \\
\hline Bald Peak $. . . \ldots \ldots . . . . . . . . .$. & 4,420 & Do. \\
\hline North Platte River at Wyoming line.. & 4,035 & Do. \\
\hline Castle Rock ......... & 4,473 & Do. \\
\hline Steamboat Rock ................. & 4,319 & Do. \\
\hline Roundtop Rock .................. & 4,479 & Do. \\
\hline Coyote Hill . . . . . . . . . . . . . . . . & 4,460 & Do. \\
\hline
\end{tabular}

SIOUX COUNTY.

\begin{tabular}{|c|c|c|}
\hline Snyder's ranch............... & 4,310 & U. S. G. S. \\
\hline Sturdivant's ranch ................. & 4,375 & Do. \\
\hline SW. corner of the county........... & 4,050 & Do. \\
\hline NW. corner of the county .......... & 4,125 & Barometer. \\
\hline Harrison ... & 4,849 & F., E. and M. V. Rwz. \\
\hline Andrews................. & 4,422 & Do. \\
\hline Glen ........... & 4,038 & Do. \\
\hline Adelia..... & 3,725 & B. and M. R. R. R. \\
\hline Mansfield........... & 3,628 & Do. \\
\hline Niobrara River at Wyoming line.... & 4,730 & Barometer. \\
\hline $\begin{array}{l}\text { Niobrara River at eastern margin of } \\
\text { the county. }\end{array}$ & 4,200 & Do. \\
\hline
\end{tabular}

14478-No. $17-03--5$ 
' GFOLOGY AND' HYDROGRAPHY OF WESTERN NEBRASKA.

List of elevations in Nebraska west of the one hundred and third meridian-Continued. SIOUX COUNTY-Continued.

\begin{tabular}{|c|c|c|}
\hline Locality. & Altitude. & Authority \\
\hline & Feet. & \\
\hline Niobrara River at Royville ... & 4,457 & U. S. G. S. \\
\hline $\begin{array}{l}\text { Niobrara River at mouth of Whistle } \\
\text { Creek. }\end{array}$ & 4,280 & Do. \\
\hline Highest sandhill in sec. 17, T. 26, R. 55 . & 5,100 & Do. \\
\hline Highest sandhill in sec. 21, T. 27, R. 56. & 5,020 & Do. \\
\hline Corbin's ranch . ......... & 4,495 & Do. \\
\hline Mud Springs $\ldots \ldots \ldots \ldots \ldots \ldots$ & 4,470 & Do. \\
\hline Coyote Springs................... & 4,520 & Do. \\
\hline McGinley Lakes .... & 4,530 & Do. \\
\hline East Spring $\ldots \ldots \ldots \ldots$ & 4,525 & Do. \\
\hline Spottedtail Springs . . . . . . . . . . . . & 4,120 & Do. \\
\hline Wind Springs ...... & 4,460 & Do. \\
\hline 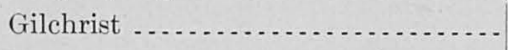 & 3,900 & Barometer. \\
\hline Montrose $\ldots \ldots \ldots$ & 3,750 & Do. \\
\hline Roundtop $\ldots .1 .1 .1$. & 4,525 & Do. \\
\hline Coliseum Rock . . . . . . . . . & 5,050 & Do. \\
\hline $\begin{array}{l}\text { Pine Ridge at Wyoming line, T. } 33 \text {, } \\
\text { R. 57. }\end{array}$ & 5,060 & Do. \\
\hline Pine Ridge, south of Andrews....... & 4,800 & Do. \\
\hline Pine Ridge, south of Glen ........... & 4,810 & Do. \\
\hline
\end{tabular}

DAWES COUNTY.

\begin{tabular}{|c|c|c|}
\hline Fort Robinson station ............. & 3,775 & Gannett. $a$ \\
\hline Crawford ...... & 3,674 & F., E. and M. V. Rwy. \\
\hline Whitney ........ & 3,404 & Do. \\
\hline Dakota Junction ........... & 3,256 & Do. \\
\hline Remington ..... & 3,660 & B. and M. R. R. R. \\
\hline Rutland .... & 4,141 & Do. \\
\hline Belmont....... & 4,493 & Do. \\
\hline Marsland ................ & 4,156 & Do. \\
\hline Summit of Pine Ridge, near Belmont. & 4,600 & Barometer. \\
\hline Niobrara River at $103 d$ meridian .... . . & 3,900 & Do. \\
\hline
\end{tabular}

BOXBUTTE COUNTY.

\begin{tabular}{|c|c|c|c|}
\hline $\begin{array}{l}\text { Hemingford } \ldots \ldots \ldots \\
\text { Girard } \ldots \ldots\end{array} \ldots \ldots \ldots \ldots \ldots$ & 4,256 & B. and M. R. R. R. \\
\hline
\end{tabular}

a Loc. cit. 


\section{N D E X}

Adelia, badlands near, view of

Adelia station, formation section from Round Top to

Alliance, rainfall at

Alluvial formations, water in occurrence and character of .

Altitudes, list of

Arikaree formation, blow out in, view of ............. 28

butte of, view of

cliffs of, view of.

conglomerate in

ections showing .............................. 27,28

$$
\text { view of }
$$

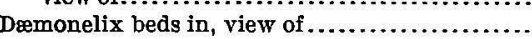

occurrence and character of....

pipy concretions in, view of ....

Brule formation to $\ldots 25,26$ showing Ogalalla formation and

springs in

Gering formation, Brule clay, and

volcanic ash in

$$
\text { water in }
$$

Artesian flow at Omaha, areas of, map showing .....

Ash, volcanic, occurrence of ..................... 35

Ashford, formations near

section near

Badlands at foot of Scotts Bluff, view of .............

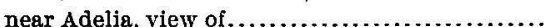

Barbour, E. H., aid by.

cited on occurrence of Dæmonelix ..............

Benton formation, occurrence and character of....... 19

Big Cottonwood Creek, measurement of

Birdcage Gap, formations exposed in, view of ........ Gering formation at

thickness of

section at.

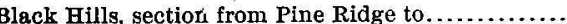

Blow out, view of

Brule clay, Gering formation lying uneonformably on,

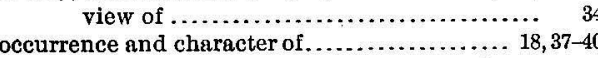
unconformity between Gering formation and, section showing.

view of Arikaree formation on ......

Arikaree and Gering formations and...........

volcanic ash in

water in .

Brule formation, lens in, view of.... Camp Clarke, discharge of North Platte River at ...

Carboniferous formations, occurrence and character of.

water in

44
Castle Rock, formations at Page. section at and near.............................. 36,38

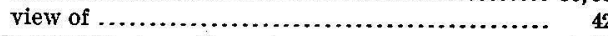

Cedar Canyon, formations at ....................... 35

section in ....................................34,35

Chadron, boring at $\ldots \ldots \ldots \ldots \ldots \ldots \ldots \ldots \ldots \ldots \ldots \ldots, \quad 47$

section at ....................................

Chadron formation, occurrence and character of ... 18,40-41

Cheyenne County, sand hills in, view of............. 22

Chimney Rock, formations exposed near ............ 31-32

Gering formation near, thickness of............. 29

sections near .............................. 32,36

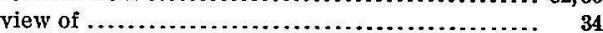

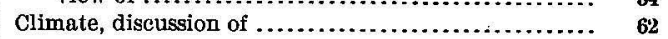

Conglomerate at base of Ogalalla formation, view of..

in Arikaree formation . ....................... 28-29

sections showing ......................... 27,28

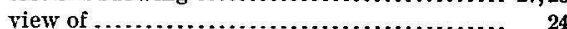

Cottonwood limestine, occurrence of ....................

Courthouse Rock, altitude of ...................... 12

formations at .................................

Gering formation at, thickness of .............. 29

section at ....................................

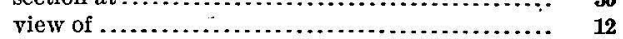

Dæmonelix, occurrence of .................... 25,27

Dæmonelix beds in Arikaree formation, view of...... 28

Dakota sandstone, occurrence and character of....... 19, 49 water in .....

Declivity of head of liquids, diagram illustrating..... 47

Dinistis, occurrence of ............................ $30-31$

Ditches, lists of......................... $55,57,58-59,61-62$

Dobson, Adna, notes by ......................... stream measurements by ..................... 52

Dome, Gering formation at.......................

Dorrington, formations near .......................

sections near .................................. 27,36

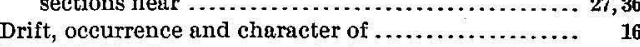

East Ash Creek, measurement of.....................

Elevations, list of ............................ 63-66

Erosion, wind, in Gering formation, plate showing .

Fault in Gering formation, view of. ...........

Fault in Gering formation, view of.................

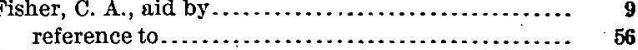

Fort Robinson, rainfall at .......................... $\quad 62$

Fort Robinson ditch, measurement of ............

Fort Sidney, rainfall at........................ 62

Freeport, Arikaree formation near, thickness of........

$\begin{array}{ll}\text { Freeport, Arikaree formation near, thickness of....... } & \mathbf{2 7} \\ \text { Funnel Rock, formations near........................ } & \mathbf{3 6}\end{array}$ section near ................................ 37

Gering, Brule clay near ....................... 38-39

Gering formation near, thickness of .............

lens in Brule formation near, view of .......... 42

rainfall at................................... 62

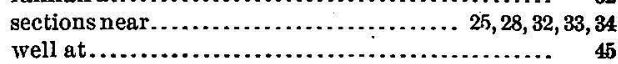




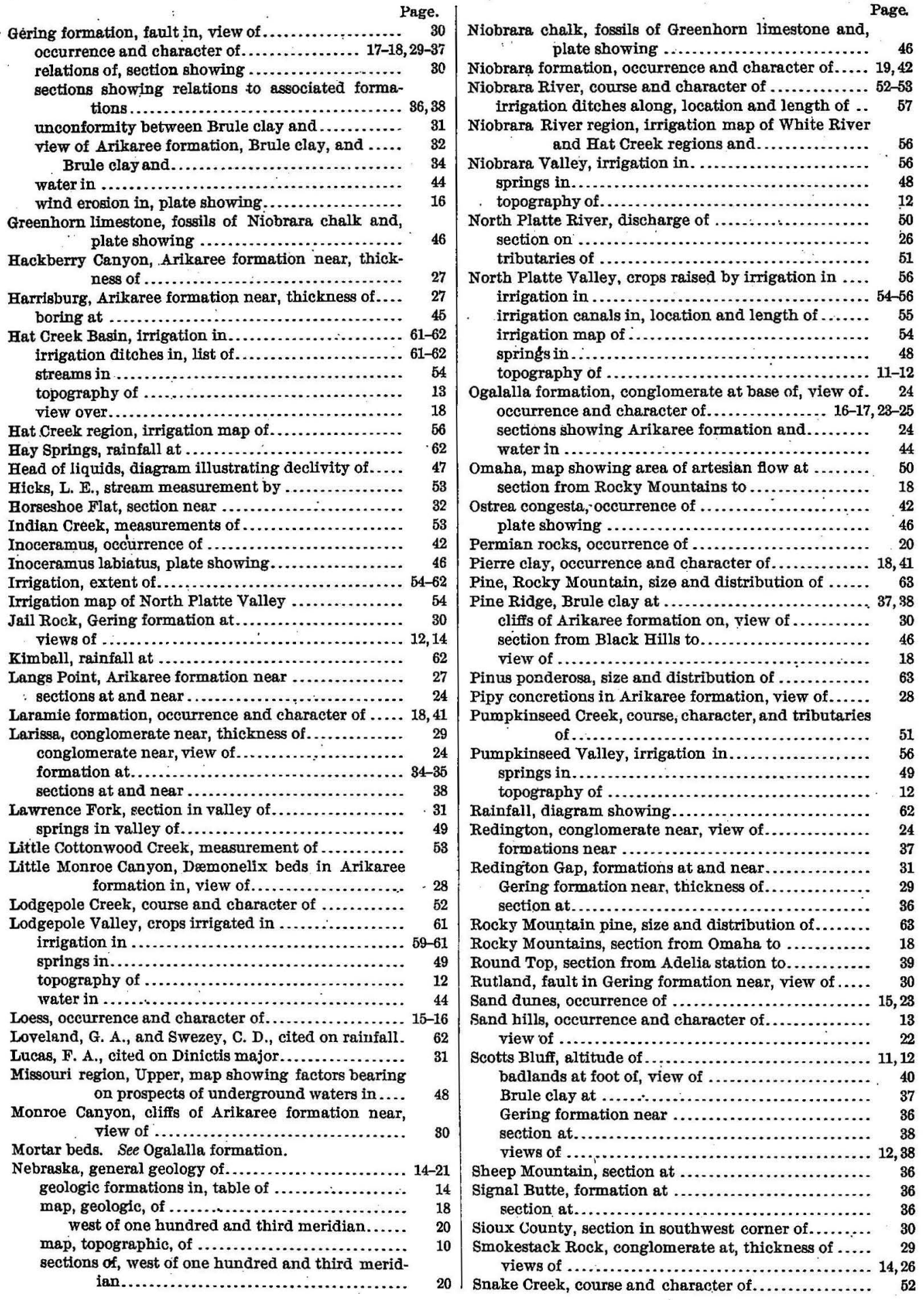


Page. Soldier Creek, measurement of...................... Sowbelly Ganyon, butte of Arikaree formation in

view of ............................... 26

53
Spoon Butte, section from Sturdivant ranch to ........ prings, characteristic features of, diägram showing

occurrence and character of.

Squaw Creek, measurement of

Streams, occurrence and character of.

Sturdivant ranch, section from Spoon Butte to

Swezey, C. D., and Loveland, G. A., cited on rainfall.

Table-land, topographic features of

Tertiary grit. See Ogalalla formation.

Titanotherium, occurrence of

Titanotherium robustum, view of.

Timber, amount and character of

distribution of, map showing.

Toadstool Park, view of.

Topography, features of ...

Twin Sisters, formations at and near.

view of .

Upper Missouri region, map showing factors bearing on prospects of underground water in ..... 48

Volcanic ash, occurrence of.................... $35,42-43$

Wabaunsee formation, occurrence of................. 20

Waters, deep-seated, occurrence of................. 45-48

Waters, underground, general conditions governing.. 43-44

horizons yielding.............................. $4:-45$
in upper Missouri region, map showing factors

bearing on prospects of

map showing distribution of ................... 46

occurrence of deep-seated...

West Ash Creek, measurement of .................. $\quad 53$

White Clay Creek, measurement of ....................

White Clay Creek, measurement of ............... tributaries of ............................... 5

White River Basin, irrigation in ................. $57-59$

irrigation ditches in, list of ..................... 58-59

topography of ........................... 12-13

White River region, irrigation map of Niobrara River

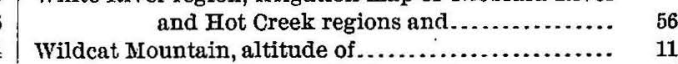

Arikaree formation at, thickness of ............... 27

section at.................................... 24

horizons yielding............................. 44-45

in upper Missouri region, map showing factors bearing on prospects of.

map showing distribution of.

occurrence of deep-seated.

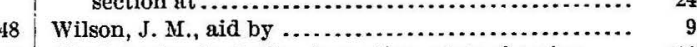

46 Wind erosion in Gering formation, plate showing .....

See also Artesian.

Windmill, irrigation by means of...................
Youngfelt, E. T. stream measurements by ....... $52,53,55$ 



\section{PUBLICATIONS OF UNITED STATES GEOLOGICAL SURVEY.}

[Professional Paper No. ]7.]

The serial publications of the United States Geological Survey consist of (1) Annual Reports, (2) Monographs, (3) Professional Papers, (4) Bulletins, (5) Mineral Resources, (6) Water-Supply and Irrigation Papers, (7) Topographic Atlas of the United States-folios and separate sheets thereof, (8) Geologic Atlas of the United States-folios thereof. The classes numbered 2, 7, and 8 are sold at cost of publication; the others are distributed free. A circular giving complete lists may be had on application.

The Bulletins, Professional Papers, and Water-Supply Papers treat of a variety of subjects, and the total number issued is large. They have therefore been classified into the following series: A, Economic geology; B, Descriptive geology; C, Systematic geology and paleontology; D, Petrography and mineralogy; E, Chemistry and physics; F, Geography; G, Miscellaneous; H, Forestry; I, Irrigation; J, Water storage; K, Pumping water; L, Quality of water; M, General hydrographic investigations; $\mathrm{N}$, Water power; O, Underground waters; $\mathrm{P}$, Hydrographic progress reports. This paper is the thirty-first in Series B, and the twenty-first in series $O$, the complete lists of which follow. ( $\mathrm{B}=$ Bulletin, $\mathrm{PP}=$ Professional Paper, WS=Water-Supply Paper.)

SERIES B, DESCRIPTIVE GEOLOGY.

B 23. Observations on the junction between the Eastern sandstone and the Keweenaw series on Keweenaw Point, Lake Superior, by R. D. Irving and T. C. Chamberlin. 1885.124 pp., 17 pls.

B 33. Notes on geology of northern California, by J. S. Diller. $1886.23 \mathrm{pp.} \mathrm{(Out} \mathrm{of} \mathrm{stock.)}$

B 39. The upper beaches and deltas of Glacial Lake Agassiz, by Warren Upham. 1887. 84 pp., 1 pl. (Out of stock.)

B 40. Changes in river courses in Washington Territory due to glaciation, by Bailey Willis. 1887. 10 pp., 4 pls. (Out of stock.)

B 45. The present condition of knowledge of the geology of Texas, by R. T. Hill. 1887. 94 pp. (Out of stock.)

B 53. The geology of Nantucket, by N. S. Shaler. 1889. $55 \mathrm{pp}$., $10 \mathrm{pls.} \mathrm{(Out} \mathrm{of} \mathrm{stock.)}$

B 57. A geological reconnaissance in southwestern Kansas, by Robert Hay. 1890.49 pp., 2 pls.

B 58. The glacial boundary in western Pennsylvania, Ohio, Kentucky, Indiana, and Mlinois, by G. F. Wright, with introduction by T. C. Chamberlin. 1890.112 pp., 8 pls. (Out of stock.)

B 67. The relations of the traps of the Newark system in the New Jersey region, by N. H. Darton. $1890.82 \mathrm{pp.}$ (Out of stock.)

B 104. Glaciation of the Yellowstone Valley north of the Park, by W. H. Weed. 1893.41 pp., 4 pls.

B 108. A geological reconnaissance in central Washington, by I. C. Russell. 1893. 108 pp., 12 pls. (Out of stock.)

B 119. A geological reconnaissance in northwest Wyoming, by G. H. Eldridge. 1894.72 pp., 4 pls.

B 137. The geology of the Fort Riley Military Reservation and vicinity, Kansas, by Robert Hay. 1896.35 pp., 8 pls.

B 144. The moraines of the Missouri Cotean and their attendant deposits, by J. E. Todd. 1896. 71 pp., 21 pls.

B 158. The moraines of southeastern South Dakota and their attendant deposits, by J. E. Todd. $1899.171 \mathrm{pp} ., 27 \mathrm{pls}$

B 159. The geology of eastern Berkshire County, Massachusetts, by B. K. Emerson. 1899.139 pp., 9 pls.

B 165. Contributions to the geology of Maine, by H. S. Williams and H. E. Gregory. 1900. 212 pp., 14 pls.

WS 70. Geology and water resources of the Patrick and Goshen Hole quadrangles in eastern Wyoming and western Nebraska, by G. I. Adams. 1902. 50 pp., 11 pls.

B 199. Geology and water resources of the Snake River Plains of Idaho, by I. C. Russell. 1902.192 pp., 25 pls.

PP 1. Preliminary report on the Ketchikan mining district, Alaska, with an introductory sketch of the geology of southeastern Alaska, by A. H. Brooks. 1902.120 pp., 2 pls.

PP 2. Reconnaissance of the northwestern portion of Seward Peninsula, Alaska, by A.J. Collier. $1902.70 \mathrm{pp} ., 11 \mathrm{pls}$.

PP 3. The geology and petrography of Crater Lake National Park, by J. S. Diller and H. B. Patton. 1902.167 pp., 19 pls.

PP 10. Reconnaissance from Fort Hamlin to Kotzebue Sound, Alaska, by way of Dall, Kanuti, Allen, and Kowak rivers, by W. C. Mendenhall. 1902. $68 \mathrm{pp} ., 10 \mathrm{pls}$.

PP 11. Clays of the United States east of the Mississippi River, by Heinrich Ries, 1903. $298 \mathrm{pp} ., 9$ pls.

PP 12 Geology of the Globe copper district, Arizona, by F. L. Ransome. 1903.168 pp., 27 pls.

PP 13: Drainage modifications in southeastern Ohio and adjacent parts of West Virginia and Kentucky, by W. G. Tight. $1903.111 \mathrm{pp} ., 17 \mathrm{pls}$.

B 208. Descriptive geology of Nevada south of the fortieth parallel and adjacent portions of California, by J. E. Spurr. 1.903. 220 pp., 8 pls.

B 209. Geology of Ascutney Mountain, Vermont, by R. A. Daly. 1903. 122 pp., 7 pls.

WS 78. Preliminar'y report on artesian basins in southwestern Idaho and southeastern Oregon, by I. C. Russell 1903. 51 pp., 2 pls.

PP 15. Mineral resources of the Mount Wrangell district, Alaska, by W. C. Mendenhall and F. C. Schrader. 1903. - pp., 10 pls.

PP 17. Preluminary report on the geology and water resonrces of Nebraska west of the one hundred and third meridian, by N. H. Darton. 1903.69 pp., 43 pls. 
SERIES O, UNDERGROUND WATERS.

WS 4. A reconnaissance in southeastern Washington, by I. C. Russell. $1897 .^{\circ} 96$ pp., 7 pls. (Out of stock.)

W8 6. Underground waters of southwestern Kansas, by Erasmus Haworth. 1897. 65 pp., 12 pls. (Out of stock.)

WS 7. Seepage waters of northern Utah, by Samuel Fortier. 1897. 50 pp., 3 pls. (Out of stock.)

WS 12. Underground waters of southeastern Nebraska, by N. H. Darton. 1898. 56 pp., 21 pls. (Out of stock.)

WS 21. Wells of northern Indiana, by Frank Leverett. $1899.82 \mathrm{pp} ., 2 \mathrm{pls}$.

WS 26. Wells of southern Indiana (continuation of No. 21), by Frank Leverett. . $1899.64 \mathrm{pp}$.

WS 30. Water resources of the lower peninsula of Michigan, by A. C. Lane. $1899.97 \mathrm{pp} ., 7 \mathrm{pls.}$ (Out of stock.)

WS 31. Lower Michigan mineral waters, by A. C. Lane. 1899.97 pp., 4 pls.

WS 34. Geology and water resourees óf a portion of southeastern South Dakota, by J. E. Todd. 1900.34 pp., 19 pls.

WS 53. Geology and water resources of Nez Perces County, Idaho, Pt. I, by I. C. Russell. 1901. 86 pp., 10 pls.

WS 54. Geology and water resources of Nez Perces County, Idaho, Pt. II, by I. C. Russell. 1901. · 87-141 pp.

WS 55. Geology and water resources of a portion of Yakima County, Washington, by G. O. Smith. 1901.68 pp., 7 pls.

WS 57. Preliminary list of deep borings in the United States, Pt. I, by N. H. Darton. 1902.60 pp. 'Out of stock.)

WS 59. Development and application of water in southern California, Pt. I, by J. B. Lippincott. 1902.95 pp., 11 pls. (Out of stock.)

WS 60. Development and application of water in southern California, Pt. II, by J. B. Lippincott. 96-140 pp. (Out of stock.)

WS 61. Preliminary list of deep borings in the United States, Pt. II, by N. H. Darton. 1902. 67 pp. (Out of stock.) .

WS 67. The motions of underground waters, by C. S. Slichter. 1902.106 pp., 8 pls.

B 199. Geology and water resources of the Snake River Plains of Idaho, by I. C. Russell. 1902.192 pp., 25 pls.

WS 77. Water resources of Molokai, Hawaiian Islands, by Waldemar Lindgren. 1903. 62 pp., 4 pls.

WS 78. Preliminary report on artesian basins in southweatern Idaho and southeastern Oregon, by I. C. Russell. 1903.51 pp., 2 pls.

PP 17. Preliminary report on the geology and water resources of Nebraska west of the one hundred and third meridian, by N.H. Darton. 1903.69 pp., 43 pls.

The following papers also relate to this subject: Underground waters of Arkansas Valley in eastern Colorado, by G. $\mathrm{K}$. Gilbert, in Seventeenth Annual, Part II; Preliminary report on artesian waters of a portion of the Dakptas, by N. H. Darton, in Seventeenth Annual, Part II; Wa.er resources of nlinois, by Frank Leverett, in Seventeenth Annual, Part II Water resources of Indiana and Ohio, by Frank Leverett, in Eighteenth Annual, Part IV; New developments in well boring and irrigation in eastern South Dakota, by N. H. Darton, in Eighteenth Annual, Part IV; Rock waters of Ohio, by Edward Orton, in Nineteenth Annual, Part IV; Artesian-well prospects in the Atlantic coastal plain region, by N. H. Darton, Bulletin No. 138.

Correspondence should be addressed to

The Director,

United States Geological Survey,

Washington, D. C.

Augiust, 1903. 


\section{LIBRARY CATALOGUE SLIPS.}

[Mount each slip upon a separate card, placing the subject at the top of the second slip. The name of the series should not be repeated on the series card, but additional numbers should be added as received to the first entry.]

\section{Darton, Nelson Horatio.}

... Preliminary report on the geology and water resources of Nebraska west of the one hundred and third meridian; by Nelson Horatio Darton. Washington, Gov't print. off., I 903 .

69, III p. 43 pl. (incl. maps), fig. $292 \times 23^{\text {cu. }}$ (U.S. Geological survey. Professional paper no. 17.)

"Reprint of the paper in the 19th Annual report of the U. S. Geological survey, 1897-98."

Subject series $\{$ B, Descriptive geology, 31 .

O, Underground waters, 21.

\section{Darton, Nelson Horatio.}

... Preliminary report on the geology and water resources of Nebraska west of the one hundred and third meridian; by Nelson Horatio Darton. Washington, Gov't print. off., I903.

69, III p. 43 pl. (incl. maps), fig. $29 \frac{1}{2} \times 23^{\mathrm{cm}}$. (U. S. Geological survey. Professional paper no. 17.)

"Reprint of the paper in the 19th Annual report of the U. S. Geological survey, 1897-98."

Subject series $\{$ B, Descriptive geology, 31.

10, Underground waters, 21.

U. S. Geological survey.

Professional papers. $\log y$ and water resources of Nebraska. 1903.

\section{U. S. Dept. of the Interior.}

see also

U. S. Geological survey.

14478-No. 17-03-6 






